\title{
High-Level Waste Storage Tank Farms/242-A Evaporator Standards/Requirements Identification Document (S/RID), Vol. 7
}

Date Published

April 1994

Prepared for the U.S. Department of Energy

Office of Environmental Restoration and Waste Management

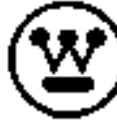

Westinghouse

P.O. Box 1970

Richland, Washington

Hanford Operawane and Enginaering Contracter for the

U.S. Depattment of Enargy under Contract DE-ACO6-87FL 10390

Approved for Public Release

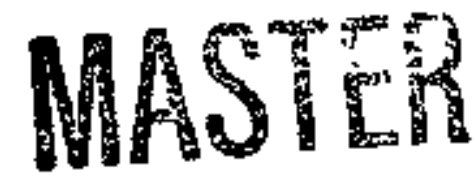

DSTFIBUTIOM OF THLS DOOUMENT IS UNM LAMTED

ur I I 


\section{DISCLAIMER}

This report was prepared as an account of work sponsored by an agency of the United States Government. Neither the United States Government nor any agency thereof, nor any of their employees, make any warranty, express or implied, or assumes any legal liabillty or responsibitity for the accuracy, completeness, or usefulness of any information, apparatus, product, or process disclosed, or represents that its use would not infringe privately owned rights. Feference herain to any specific commercial product, process, or service by trade name, trademark, manufacturer, or otherwise does not necessarily constitute or imply its endorsement, recommendation, or favoring by the United States Government or any agency thereof. The views and opinions of authors expressed herein do not necessarily state or reflect those of the United States Government or any agency thereof. 


\section{DISCLAIMER}

Portions of this document may be iilegible in electronic image products. Images are produced from the best available original document. 


\section{INFORMATION RELEASE REOUEST PUELIC DOCUMENT CHANGE/REVISION \\ (Shart form No. T)}

1. Base Dócument ID Number: WHC-EP-0750

2. Base Document Title:

High-Level Waste Storage Tank Farms/242-A Evaporator Standards/Requirenents Identfficatjon Doctuent (S/RIO)

3. Change/Revision Number: 1/ 10 of the 18 Functional Aroas

4. Change/Revișion Date: $\quad 09 / 14 / 94$

5. Unclassified Catogory:" UC $-N / R$

6. Budget \& Reporting Code:* B\&R - N/R

I verify this chenge/revision to the base doctument indicated above:

- Complies with the provisions of WHC-CM-3-4

- Contains no Limited-Use information

- Contains no classified or Applied Technology references

- Does not change the intent or meaning of the base document

- And, the base document itself is approved for public release.

7. Responsible Manager: Oavid L. Burt

MSIN: $373-3091$

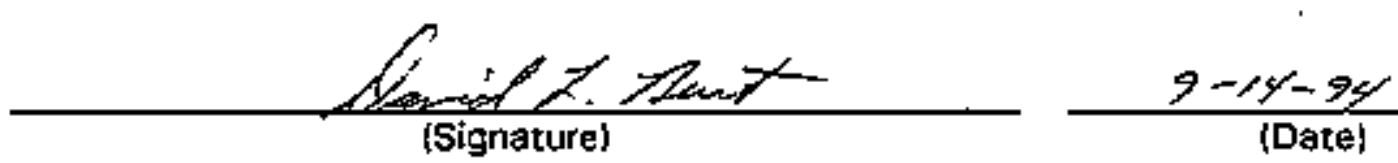

8. Information Release Administration Specialist: * *

Not Reauired

$$
\text { (Signature) }
$$

(Date)

- Required only for full revisions transmitted to OSTI.

- Required only for fult revisions. 
(2) Title

High-Level Waste Storage Tank Farans/242-A Evaporator Standards Requirements Identiftcation Docursent (S/RID)

СMAHCE COHTROL RECOORD

\begin{tabular}{|c|c|c|c|}
\hline \multirow{2}{*}{ Rerision } & \multirow{2}{*}{ (4) Deseription of Change - Replafe, Nod, and Deletie Pages } & \multicolumn{2}{|c|}{ Nuthorized for Release } \\
\hline & & (5) Cog Ener & (6) Eog. Mer, \\
\hline \multirow[t]{12}{*}{$1 *$} & $\begin{array}{l}\text { (7) Replace the following functional } \\
\text { areas: }\end{array}$ & 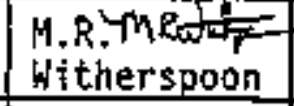 & $0.1 .80 z^{\mathrm{B}}$ \\
\hline & 1.0 Management Systems & & \\
\hline & 3.0 Confiquration Hanagement & & \\
\hline & 4.0 Traíning and Qua? ifications & & \\
\hline & 5.0 Emergency Management & & \\
\hline & 7.0 Enqíneering Desiqn & & \\
\hline & 8.0 Construction & & \\
\hline & 12.0 Fire Protection & & \\
\hline & 13.0 Packaging and Transportation & & \\
\hline & $\begin{array}{c}15.0 \text { Research \& Development and } \\
\text { Experimental Activities }\end{array}$ & & \\
\hline & 18.0 Enviranmentaf Protection & & \\
\hline & Revised in response to DOE-HQ comments. & & \\
\hline \multirow[t]{4}{*}{$2 *$} & Replace the following functional area: & MR Withersnood & De gurt $9 / 19 / 94$ \\
\hline & 13.0 Packaqing and Transoprtation & 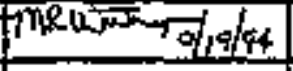 & 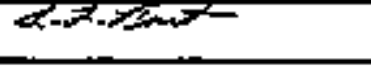 \\
\hline & *Revisied in resoonse to DOE-HO comments. & & \\
\hline & $\cdot$ & & \\
\hline & & & \\
\hline & & & \\
\hline & & & \\
\hline & & & \\
\hline & & & \\
\hline & & & \\
\hline & & & \\
\hline & & & \\
\hline & & & \\
\hline & & & \\
\hline & & & \\
\hline & & & \\
\hline & $\overline{-}$ & & \\
\hline & & & \\
\hline & & & \\
\hline & & & \\
\hline & & & \\
\hline
\end{tabular}




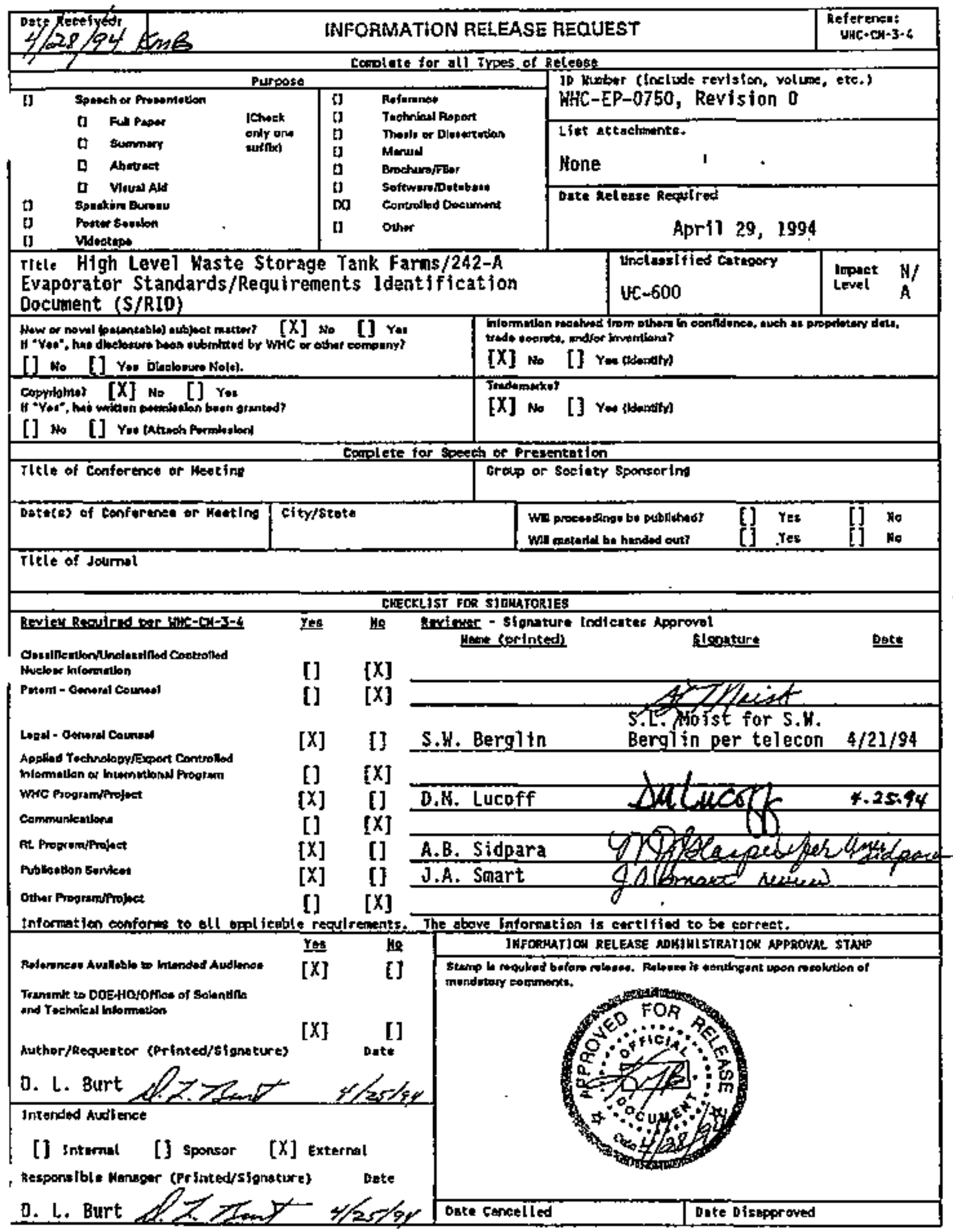




\section{NOTICE}

The High-Level Waste Storage Tank Farms/242-A Evaporator Stardards/Requirements Identification Document (S/RID) is contained in multipte binders. The content of the binders by functional area is as follows:

Volume 1 Revision

Management Systems . . . . . . . . . . . . . . . . 1

Configuration Management $\ldots \ldots \ldots \ldots \ldots \ldots \ldots \ldots$

\section{Volume 2}

Quality Assurance ....................

Training and Qualification . . . . . . . . . . l Emergency Planning and Preparedness . . . . . . . . 1

Construction $\ldots \ldots \ldots \ldots \ldots \ldots \ldots \ldots \ldots \ldots$

Volume 3

Safeguards and Security $\ldots \ldots \ldots \ldots \ldots \ldots \ldots$

Engineering Design . . . . . . . . . . . . 1

Maintenance $\ldots \ldots \ldots \ldots \ldots \ldots \ldots \ldots \ldots$

Volume 4

Radiation Protection . . . . . . . . . . . . . . o

Operations

\section{Volume 5}

Fire Protection . . . . . . . . . . . . . . 1

Packaging and Transportation ............

\section{Volume 6}

Environmental Restoration and Waste Management . . . . . . 0 Research \& Development \& Experimental Activities .... . . I Nuclear Safety $\ldots \ldots \ldots \ldots \ldots \ldots \ldots \ldots \ldots$

\section{Volume 7}

Occupational Safety and Health $\ldots \ldots \ldots \ldots \ldots$ Environmental Pratection . . . . . . 


\section{WESTINGHOUSE HANFORD COMPANY}

\section{REQUIREMENTS}

\section{IDENTIFICATION}

DOCUMENT

FACILTY;

HIGH LEVEL WASTE STORAGE TANK FARMS/242-A EVAPORATOR
FUNCTIONAL AREA:

Occupational Safety and Health 


\section{REQUIREMENTS IDENTIFICATION DOCUMENT FIGH LEVEL WASTE STORAGE TANK FARMS Occupational Safety and Health}

\section{TABLE OF CONTENTS}

17,0 OCCUPATIONAL SAFETY AND HEALTH $\ldots \ldots \ldots \ldots \ldots \ldots \ldots \ldots$

$\$ 7.1$

PROGRAM MANAGEMENT $\ldots \ldots \ldots \ldots \ldots \ldots \ldots$

17.1 .1

17. . 2

17.t.3

17.1.4

17.2

$17,2.1$

17.2 .2

17.2 .3

17.2 .4

17.2 .5

17.3

17.3 .1

17.3.2

17.3 .3

17.3.3.1

$[7,3.3 .2$

17.3 .4

17.3 .5

17.4

17.4.1

17.4.2

17.4 .3

17.4.4

17.4 .5

$17,4.6$

17.4 .7

17.4 .8

17.4 .9

17.5
Program Policy and Procedures $\ldots \ldots \ldots \ldots \ldots$

Occupational Safecy and Health Goals and Objectives $\ldots \ldots \ldots \ldots$. 5

Management Commitment and Resources $\ldots \ldots \ldots \ldots \ldots$

Requests for Exemptions $N$ ariances $\ldots \ldots \ldots \ldots \ldots \ldots$

HAZARD ANTICIPATION, IDENTIFICATION, AND EVALUATION $\ldots . .11$

Hazard Assessment Program $\ldots \ldots \ldots \ldots \ldots \ldots \ldots \ldots$

Hazard Reporting System $\ldots \ldots \ldots \ldots \ldots \ldots$. . . . . . . . . . . 14

Investigation of Occurrences, Accidents, and Near Misses . . . . . . 17

Infury and Illness Trend Analysis $\ldots \ldots \ldots \ldots \ldots \ldots \ldots$

Occupational Safery and Health Inventory System $\ldots \ldots \ldots \ldots$

OS\&H GAZARD PREVENTION AND CONTROL $\ldots \ldots \ldots \ldots \ldots \ldots$

Facility, Hazard Monitoring, Sampling, and Surveillance . . . . . . . 24

Engineering Controls . . . . . . . . . . . . . . . . . . . 27

Administrative Controls . . . . . . . . . . . . . . . 30

Definitions of Terms $\ldots \ldots \ldots \ldots \ldots \ldots \ldots \ldots$

Handing Dntms and Containers $\ldots \ldots \ldots \ldots \ldots \ldots$

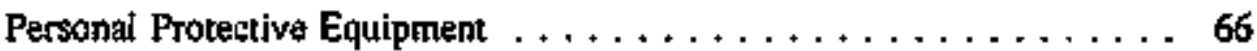

Facilty and Equipment Safety Inspections and Maintenance $\ldots \ldots \ldots$. .

OCCUPATIONAL HEALTH PROGRAM $\ldots \ldots \ldots \ldots \ldots$

Health Examinations $\ldots \ldots \ldots \ldots \ldots \ldots \ldots \ldots$

Health Maintenance and Preventive Medicine . . . . . . . . 86

Diagnosis and Treatment . . . . . . . . . . . . . . 88

Fitness for Duty $\ldots \ldots \ldots \ldots \ldots \ldots \ldots \ldots \ldots \ldots$

Medical Facilities and Equipment $\ldots \ldots \ldots \ldots \ldots$. . . . . . . .

Professional Development of Occupational Staff $\ldots \ldots \ldots \ldots$. . . . 95

Emergency Planring $\ldots \ldots \ldots \ldots \ldots \ldots \ldots$

Health Records and Reporting . . . . . . . . . . . . . 97

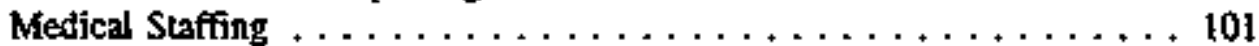

OCCUPATIONAL SAFETY AND HEALTH TRAINING $\ldots \ldots \ldots \ldots \ldots, \ldots 107$

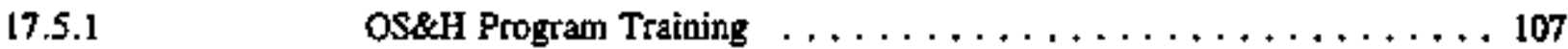




\section{REQUIREMENTS IDENTIFICATION DOCUMENT}

HIGH LEVEL WASTE STORAGE TANK FARMS

Occupational Safety and Health

17.5.2

17.5 .3

17.6

17.6.1

17.6 .2

17.6 .3

17.7

17.7 .1

17.7 .2

17.7 .3

17.7 .4

17.7 .5

17.7 .6

17.7 .7

17.7 .8

17.7 .9

17.7 .10

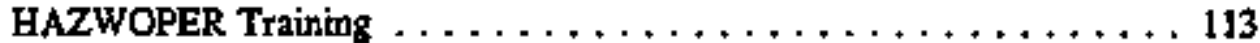

OS\&H Training, Recordkeeping, and Reporting $\ldots \ldots \ldots \ldots \ldots$. . . 123

RECORDKEEPING AND REPORTING $\ldots \ldots \ldots \ldots \ldots \ldots$

OS\&H Record Management and Expostre Reporting . . . . . . . . 123

Oscurrence Reporting . . . . . . . . . . . . . . . . . 124

Occupational Injury and lllness Reporting $\ldots \ldots \ldots \ldots \ldots \ldots \ldots$

KEY PROGRAM INTERFACES $\ldots \ldots \ldots \ldots \ldots \ldots \ldots \ldots$

Engineering Design . . . . . . . . . . . . . . . . 125

Emergency Preparedness and Management (E\&M) . . . . . . . . 125

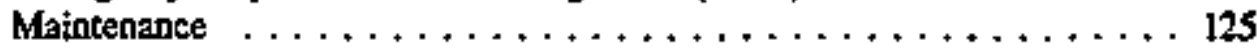

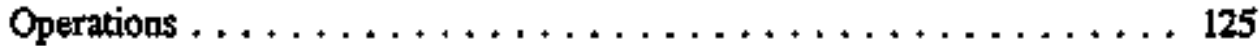

Radiation Protection . . . . . . . . . . . . . . . . . . . . 125

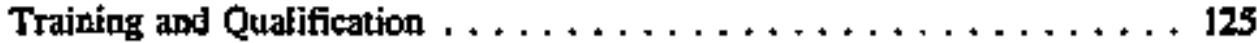

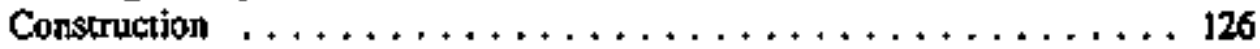

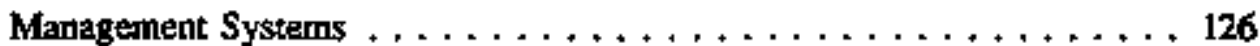

Packaging and Transportation . . . . . . . . . . . . . . 126

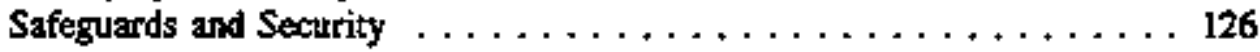




\section{REQUIREMENTS IDENTIFICATION DOCUMINT \\ HIGH LEVEL WASTE STORAGE TANK FARMS \\ Occupational Safety and Health}

\subsection{OCCUPATIONAL SAFETY AND HEALTH}

\section{INTRODUCTION}

This Requirements Identification Document (RID) describes an Occupational Heatth and Safety Program as defined through the Relevant Doe Orders, regulations (OSHA, WAC, etc.), industry codes/standards, industry guidance documents and, as appropriate, good industry practice. The definition of an Occupational Health and Safety Program as specified by this document is intended to address Defense Nuclear Facilities Safety Board Recommendations 90-2 and 91-1, which call for the strengthening of DOE complex activities through the identification and application of relevant standards which supplement or exceed requirements mandated by DOE Onders.

This RID applies to the activities, personnel, structures, systems, components, and programs involved in maintaining the facility and executing the mission of the Tank Farms. The physical boundaries within which the requirements of this RID apply are the Singie Shell Tank Farms, Double Shell Tank Fams, 242-A Evaporator-Crystallizer, 242-S,T Evaporators, Liquid Effluent Retention Facility (LERF), Purgewater Storage Facility (PSWF), and all interconnecting piping, valves, instrumentation, and controls. Also included is all piping, valves, instrumentation, and controls up to and including the most remote valve under Tank Farms control at any other Hanford Facility having an interconnection with the Tank Farms. The boundary of the structures, systems, components, and programs to which this RID applies, is defined by those that are dedicated to and/or under the control of the Tank Farms but excludes general site facilities such as the site electric power system, site telecommunications systems, and roads serving the Hanford Reservation.

The Occupational Health and Safety Program defined in this document is presented in the form of program elements and sub-elements. The accompanying descriptive text briefly addresses the controts necessary for implementation of each element and sub-element. The elements used to outline the basis of a comprehensive Occupational Health and Safety Program are as follows:

- Program Management

- Hazard Anticipation, Identification, and Evaluation

- OS\&H Hazard Prevention and Control

- Occupational Health Program

- Occupational Safety and Health Training

- Recordkeeping and Recording

- Key Program Interfaces

This document shall be used as a baseline to assess the existing Occupational Health and Safery Program at the Tank Farm Facilities. Complete program definition, including overall infrastructure and interfaces, shall be evaluated with regard to the elements and sub-elements identified in this document. 


\section{REQUIREMENTS IDENTIFICATION DOCUMENT HIGH LEVEL, WASTE STORAGE TANK FARMS \\ Occupational Safety and Health}

This ejement addresses the mamagement and organizstional structure needed for an effective Health and Safety Program. A formal structure is necessary to ensure high level of performance and safety is hieved durimg work activities. This element outfines the need for estoblishing clear and cancise Health and Safery policy, poils and objectives. The responsibility that managers, supervisors, and employees are assigned relative to bealch and safery during the performinte of work is also addressed. The neceseary management commitment to a sefe work environment and the resources reguired to support such a commitmeat are also discussed.

\section{FACLITY REQUIREMENT SOURCE: 29CFR1910 Part 120(b)(2)(i)}

"Organizational structure part of the site program. The organizaticosl structure part of the program shall establish the specific chain of cornmand and spectify the overall responsibilities of supervisors and employees. It shall inciude, at 2 minimum, the following olements:

(A) A geoeral supervisor who has the responsibility and atthority to direct all bazardous waste operations.

(B) A site safedy and bealth supervicor who bas the responsibility and authority to develop and implement the site safety and heolth plan and verify compliance.

(C) All other personnel needed for hazandous waste site operations and emergency response and their general functions and responsibilities.

(D) The lines of authority, responsibility, and commonication."

\section{FACILITY REQULREMENT SOURCE: 29CFR1910 Part 120(b)(2)(i)}

-The organizational structure shall be reviewed and updated zs necessary to reflect the current status of waste site operstions."

\section{Program Policy and Pencedures}

This subrelement delineates the policy requirtments for a Health and

Safoty Program. The health and sofery policy shall be written and elearly

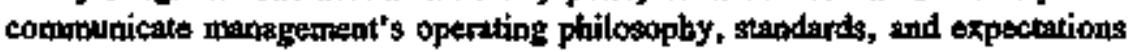
with regard to heotth and safety. The policy shall also assign responsibility for the implenentation of the stated health and safety policy.

Specifically, the health and safety program policy shall cleaty and concisely state management's expectotions concerning health and safery issues thet may arise during the performanes of work. Management's overall commitment to hesith and safery shall be clearly commumicated, including the relative valpe management places on health and safety in the work place.

Specific controls which govero the prepsration and juplementation of program policies are addressed in the Policies and Protedures section of the Management Systents Functianal Area. 
WHC-EP-0750

\section{REQUIREMENTS IDENTIFICATION DOCUMENT HIGH LEVEL, WASTE STORAGE TANK FARMS Occupational Safety and Health}

\section{FACILITY REQUIREMENT SOURCA: 29CFR1910 Part 120(b)(1)(i)}

"Safety and health program.

Geotrial.

Employers shalt develop and inplenutent a written sefety and hesith program for their employes involved in tarardous waste operations. The program shall be designed to jitentify, evaluate, and contrel safery and health hazarids, and provide for emergency rosponse for bazardaus waste operations."

\section{FACILITY REQUIREMENT SOURCE: 29CFR1910 Part 120(b)(1)(1i)}

"The written safety acd heatth program shall incorparate the following:

(A) An organizational struchure;

(B) A comprebensive workplan;

(C) A site-specific safery and health plan which need got repeat the employer's standard operating procedures required in paragraph (b)(1)(ii)(F) of this section;

(D) The sattry and healtb training program;

(E) The medical surveillance prograpu;

(F) The employer's standard operning procedures for safety and health; and

(G) Any necessary interface between general program and site specific actrvities."

\section{FACIITY REQUIREMENT SOURCE; 29CFR1910 Part 120(b)(1)(iv)}

"Contractors and sub-contractors. An employer who retrins contractor or sab-contractor services for work in hazardous waste operations shall inform those contrectors, sub-contrectors, or their representatives of the site emergency response procedures and any polential fire, explosion, bealth, sufety or other bazards of the hazardous waste operation that have been identified by the employer, ifacluding those identified in the employer's information program."

\section{FACILITY REQUIREMENT SOURCE: 29CFR1910 Part 120(b)(1)(v)}

"Program availability. The written saftery and bealth program shall be made available to any contractor or subcontractor or their representative who will be involved with the hazardous wrste operation; to employees; to employee designated representratives; to OSHA personnel, and to personnel of other Federzl, state, or local agencies with regulatory authority over the site."

\section{FACILITY REQUIREMENT SOURCE: 29CFR1910 Part 120(g)(I)(iti)}

The exployer shall not implement a schedule of erciployee rotation as a means of compliance with pernissible exposure limits or dose limits except when there is no other feasibte way of complying with the airhome or dermil dose limits for ionizing radiation.

\section{FACILITY REQUIREMENT SOURCE: S4FR3904 Pait (c)(1)(v)}

"Assign and communicate responsibility for all aspects of the program, so that managers, supervisors, and employees in all parts of the organization know what performince is expected of them." 


\section{REQUIREMENTS IDENTIFICATION DOCUMENT HIGH LEVEL WASTE STORAGE TANK FARMS Occupational Safety and Health}

\section{FACIITYY REQUIREMENT SOURCE: 54FR3904 PATt 3904.(a)(1)}

"Employers are advised and eccouraged to institute and maintain in their establishments a program which provides systematio policieg, procedunes, and gractices that are adexpate to recognize and protect their employe from oceupational safety and bealth hazards."

\section{FACILITY REQUIREMENT SOURCE: 54FR3904 Part 3904.(a)(4)}

"The extent to which the program is described in writing is kss important than how effective it is an practice. As the size of a worksite or the complexity of a hazardous operation increases, however, the meed for written guidance increases to easure clear communication of policies and priorities and consistent and fait ipplication of raies."

\section{FACILITY REQUIREMENT SOURCE: 54FR3904 Part 3904.(c)(1)(j)}

"State clearly a worksite policy on sale and beolthful work and working conditions, so that all personetel with responsibility at the site and personel at ofher locations with responsibility for the sito donterstend the priority of safery and health protection in relation to othes organizational values."

\section{FACILITY REQUIREMENT SOURCE; ANSI-Z244.1-1982 Section 3.1.1}

-Policy.

The lockout/tagout policy stall require all personnel to comply with the lockout/agout procedure." .

\section{FACILITY REQUIREMENT SOURCE: DOE/EHO135 IH.2.3}

-*3. Industrial bygiene policy statements are consistent with the requirements of DOE \$480.10."

\section{FACILITY REQUIREMFENT SOURCE: DOEJEH0135 OS.2.3}

**3. Osctpational safety policy statemsets are consistent with the requirements of applicable DOE Orders."

\section{FACILITY REQUIREMENT SOURCE: DOEJEHO135 PP.2.2}

"*2. Written occupational safery and iodustrial bygiene policies are readily available to alt organization elements, periodically reviewred, and kept current."

\section{FACILITY REQUIREMENT SOURCE: DOE/EH0135 PP.2.3}

"3. Personnel protection policy statements are consistemt with the requirements of applicable DOE Orders.". 
WHC-ER-0750

\section{REQUIREMENTS IDENTIFICATION DOCUMENT HIGH LEVEL WASTE STORAGE TANK FARMS Occupational Safety and Health}

\section{Occupantinnal Snfety and Health Eoals and Objectives}

This aubelement defines the requirements for establishing Health and Sufety Program goals and objectives which support a syatematic, loug-term approach to performance improvement. These goals and objectives shatl also be used as a tool for measuring the effectiveness of the Healtin and Sinfery Program. The program goals and objectives shall reflect management's expectations concerning health and safety. The program goals and objectives shall be adequately commutricated to all employes and visitors.

Specific heatth and safery goals and objectives shall be developed besed on comparisons with other DOE and commercial bacilities. Such goals and objectives stall be ouditable, measurable, realistic, and challeoging. The purpose of establishing these gods and objectives is to improve and monitor bealth and safety perfordance, achieve complete identification of bealth and safety hazerds in the workplace, and timit the consexpences associated with a particular hazard to as low as reasonably achievablo. Additionally, performance indicators stall bo develoged and routine reportiag initiated to provide a mechanism for measuring workplace pefformance apainst the desired gosls and objectives.

Meeting the goals and objectives develoged in accondance with this sub-etement will reguire proper implementation of the programmatic controls dictuted by the other etements and sub-elements contained in this document. For example, a goal ptay be to reduce electricel strock accidents while performing maintenance. This goal may be pertly accomplisbed through the development and implementation of a more thorough etectrical safecy training course. This training program would be devatoped and irmplemented in accordance with the Training sub-element detailed in this document.

\section{FACILITY REQUIREMENT SOURCE: 29CFR1910 Part t20(b)(3)(ii)}

"The comprehtensive workplen shall define work tasks and objectives and identify the methods for accomplishing those tasks and objectives:-

\section{FACILITY REQUIREMENT SOURCE: 54FR3904 Part (c)(1)(ii)}

- Fistablish and communicate 2 cleor goal for the safety and benlth program and objectives for meeting that goal, so that all members of the orgenization understand the results destred and the measures planned for achioving them."

\section{FACILITY REQUIREMENT SOURCE: DOE/EH0135 IH.1.8}

"8. Momagement establishes specific goals and objectives for reducing the frequency and severity of potential exposures to oscupational health hazards."

\section{FACILITY REQUIREMENT SOURCE: DOEIEH0135 OS.1.1}

**. Line management assures the implementation of the cocupational soffety 
WHC-ER-0750

\section{REQUIREMENTS IDENTIFICATION DOCUMENT HIGH LEVEL WASTE STORAGE TANK FARMS Occupational Safety and Health}

programs that effectively maintrin workpleses frie of sfecy concerns."

\section{FACILITY REQUIREMENT SOURCE: DOE/EHO135 0S.3.7}

7. Housekeeping practioes and programs reflect a commitmont to minimize occupational safety concerns."

\section{Management Committment and Besources}

This sub-element adtresses the ueed to establist management commitment and provide the resources necessery to fully implement an effective Health and Safery Program. The decessary condrols shall be developed to eusure that sufficiedt staftiog, equipment, and facilities ato provided to meet the program policy, goals and objectives. These controls shall tefint tits methodology used to determine present and tuture staffing, equipment, and fexility requirements (including budget requests and funding leveis). The development and implementation of a process with accurately evaluates current resource tovels with respect to desired health and sefiety performenges levels is imptrative to this sub-elemeat.

\section{FACIIITY REQUIREMIENT SOURCE: 54FR3904 Part (c)(1)(iti)}

"Provide visible top management involvement in implementing the program, so that al] will understand that managemeat's commitment is serions."

\section{FACILITY REQUIREMENT SOURCE: 54FR3904 Part (c)(1)(vi)}

"(c)(1)(vi) Provide adequate anthority and rescurces to responsible parties, so that assigaed responsibilities can be met."

\section{FACILITY REQUIREMENT SOURCE: 54FR3904 Part 3904.(b)(1)}

"Management commitment and enploye involvement art complementary. Management commitment provides the motivating force and the resocures for ortganization. In an effective program, management regards worket safety and bealth is a fundamental value of the organization and applies its commitment to safecy and bealth protection with as much vigor as to other organizationai purposes. Employee involvement provides the means through which workers develop and/or axpress their own conmitment to safety and health protection, for themselves and for their follow workess."

\section{FACII.TY REQUIREMENT SOURCE: DOE/EH0135 IH.1.2}

"2. The industrial bygiene staff is organized to assure that the staff has 2 direct lige of communication with top management. Reports and recommendations of the tectiniced staff are not subject to ingppropriate gon-technical management review and approval." 


\section{REQUIREMENTS IDENTIFICATION DOCUMENT HIGH LEVEL WASTE STORAGE TANK FARMS \\ Occupational Safety and Health}

\section{FACILITY REQUIREMENT SOURCE: DOEJEH0135 IH.1.6}

"6. Resourues are allocated and establisbed to meet the operstional requirements of the incustrial hygiese programs."

\section{FACILITY REQUIREMENT SOURCE; DOE/EHO135 IH.1.7}

7. Ocetupational health issues are factors in establishing priorities for spending on copital improverneots projects,"

\section{RACIITY REQULREMENT SOURCE: DOE/EF0135 EH.3.10}

"10. Housekeeping prectices and programs reflect a commitment to minimize contamination of areas, equiputent, and/or personnel. The basic prentise is controt of the bealth hazards at the source."

\section{FACILITY REQUIREMENT SOURCE: DOE/EH0135 IH.3.7}

7. Specialized equipment and tecknical resparces are maintained and optrated in a reliable and proper mmoner."

\section{FACILITY REQUIREMENT SOTRCE: DOE/EH0135 OS.1.2}

"2. The cecupational safety technical support staff is organized to zssure that the steff has a direct line of communication with top manigement. Reports and recommendations of the tectmical staff are not subject to inappropriate non-tecknicai management neview and agproval.*

\section{FACILITY REQUTREMENT SOURCE: DOEJEHO135 0S.1.3}

- 3. The staff responsible for the direction and operstion of cocopational safety programs are professionally qualified and have sufficient tion and sultiority to impitement the estriblished program."

\section{FACII,IIY REQUIREMENT SOURCE: DOE/EH0135 OS.1.7}

*7. Occupational safety issues are factors in establishing priorities for spending on capital improvements projects."

\section{FACILITY REQUIREMENT SOURCE: DOE/EH0135 05.3.7}

7. Housekeeping pratices and prograns toflect a commitment to minimiza oceupational safety concerns."

\section{FACILITY REQUIREMENT SOURCE: DOE5480.10 Section 9.d(1)}

"Indiustrial Hygiene Staff

(1) The staff responsible for the direction and operation of the industrial bygiene prograrn must be professionally qualified, adequate in number, and have sufficient time and authority to design and jomplement tho 


\title{
REQUIREMENTS IDENTIFICATION DOCUMENT FIGH LEVEL WASTE STORAGE TANK FARMS Occupational Safety and Feaith
}

\author{
intustrial hygiene program set forth in this Ointer."
}

FACILITY REQUIREMENT SOURCE: DOES480.10 Section 9.d(2)

-As an altertative to a staff industrial hygituist, consultants qualified in industrial bygieas and knowiedgeable of the requiraments of this Order may be retained to angment the contractor staff and perform comprehensive or specific industrial bygiene surveys as needed."

\section{Beaduests for Exemptions/Variance}

This sub-etement adfresses the progremmatic controis necessary to identify and justify exemptions and variances to DOE Orders/Directives or OSHA regulations. The methods used to identify and justify exemptions and vartances shal] be clearly defined. Preparation of exemptions/variances shall be ciesrly defined in procedures. Tracking and maintenance of requests for exempetions/variances shall also be clesily defined.

\section{FACILITY REQUTREMENT SOURCE: DOE/EHO135 LF.1.10}

"10. A formal program is established to track the correction of identified deficiencies and deviations from preseribed standards."

\section{FACILITY REQUMGMENT SOURCE: DOEJEH0135 OS.2.9}

"9. A formal program is established to track the correction of identified deficiencies and deviations from preseribed standards. "

\section{FACILITY REQUIREMENT SOURCE: DOES483.1A Chapter I, Section 4.a}

"a. Tempocary Variances.

(1) A contractor may apply to the appropriate $C O$ or $C O$ representative for a temporary variance from the DOE-prescribed OSHA standards. A request for a temporary variance shell cantain:

(a) A specification of the standard from which the contractor seeks a variance.

(b) A representation that the contractor is portable to comply with the standard and a detailed stetement of the reacons therefor.

(c) A statement of the steps the contractor bas taken and will take to protect employees from the bazard covered by the standard, to include the conditions the contractor must maintain and the practices, means, methods, operations, and processes which must be adopted and utilized to the extent they provite protection equivalent to that of the standard for which 


\section{REQUIREMENTS IDENTIFICATION DOCUMENT HIGH LEVEL WASTE STORAGE TANK FARMS Occupational Safety and Health}

the variance is requested.

(d) A certification that the contractor has informed employes of the application by giving a copy thereof to their aulborized representative (where appilicable), posting a statement, giving a summary of the request, and specifying where a copy may be examined (e.g-, at the place or places where notices to employees are mormally posted) and by other appropriate means. A description of bow employees bave been informed shall be contained in the certification. The information to omployees also shall inform them that they may comment on the request to the appropriate $\mathrm{CO}$ or $\mathrm{CO}$ representative.

(s) A statement of when the contractor will be abte to comply with the standard and what steps have beon taken and will be taken by the contrector to come into compliance with the standard.

(2) The $\mathrm{CO}$ or $\mathrm{CO}$ representative, the safoty and health mansiger, and other appropriate elements of the fietd organization shall review the contractor's request and the employees' comments and submit the field arganizotion's recomnendation, together with the contractor's request and contractor employes comments, to the Director of Operational Safely (EP-32) within 30 days of receipt of the request. After review and evaluation of the request, comments, and recommendation and after coordination with the appropriate program office(s), EP-32 strall approve a temporary variance if the request escoblishes that (a) the contractor is unable to comply with the standard because of unavailability of professionat or technical personnel materials or equipment funding aeeded to come into compliance with the standard, or because necessary construction or alteration of facilities must be completed in order to comply: (b) the contractor is taking all available steps to safeguard employees against the bazards covered by the standard; and (c) the contractor has an effective program for coming into compliance with the standard as quickly as practicable.

(3) A temporary variance may be in effect for no longer than the period needed by the contractor to achieve connpliance with the standard or I yer, whicbever is shorter, except that in unusuel circumstances $(0.8+$ lack of programmatic funding) such a temporary variance may be repewed noe more than onca Such a rentetral also shall be in effect for no longer than 1 year. An application for renewal must be filed and processed in the mannes specified in paragraph 4a(2), above at least 90 days prior to expiration of the temporary variance. Employees also shall be given an opportunity to review and comment on a request for a renewal as outlined on pxge l-2, parograph 4 e(t)(d).

(4) The Director of Operational Safety shall inform the field organjestion of the results of the ovaluation of the request for a temporary varingce or the extension thereof, within 180 days of recejpt of the request" 


\title{
REQUIREMENTS IDENTIFICATION DOCUMENT HIGH LEVEL WASTE STORAGE TANK FARMS Occupational Safety and Health
}

\author{
FACILITY REQUIREMENT SOURCE; DOE5483.IA Chapter I, Section 4.b
}

Termaneat Variagoes.

(1) DOE contractors may apply to the appropriats CO or CO representative for a permaneat variance from the prescribed OSHA standorcs. The request for variance stall contain the same information specified on page $\mathrm{I}-2$, paragraphs 4a(1)(2)-(d). The CO or CO representative, the tocal safety and bealth office, and other appropriate ekements of the field organization shall seview the contractor's tequest and the employes comments and submit their recommendation together with the contractor's request and cortractor employee comments, to the Director of Operational Safety (EP-32) within 30 days of receipt of the request. After review and evaluation of the request, comments. and recoummendation, and after coordination with the appropriate program office, EP-32 shall stibmit a recommendation to the Assistant Secretery. Environmental Protection Safety, and Emergeocy Preparedoess (EP-1), for consideration.

(2) If EP-1 deteraines that the coatractor has demanstrated that the conditions practices, means, methods, operations, or processes to be used will provide amployment and a place of employment which is as safe and bealthful as those which would prevail if the contractor complied with the standard, a permanent variance shall be approved and the requesting organization stiall be notified accordingly, within 180 days of receipt of the request by EP-32.

(3) However, if the permanent variance request is not approved by EP-1, the requesting organization shall be notified of the rationsle for the

determination, within 180 days of receipt of the request by EP-32."

\section{FACILITY REQURREMIENT SOURCE: WAC-296-24 Section 010}

"Realizing that conditions may exist in operations under which certain state standards witl not have practical application, the director of the department of labor and industries or his authorized representative may, pursuant to this section, RCW 49.17 .080 and/or $49.17,090$ and appropriats administrativo rules of this stats and the department of Jabor and industries and apon receipt of application and after adequate investigation by the department, permits variation from these requirements when other means of providing an equivalent messure of protection are afforded. Such variation granted shill be limited to the particular case of cases covered in the application for variance and may be revoked for cause. The permit for variance shall be consicuously posted on the premises and shall remain posted during the time it is in effect. All requesis for variances from safoty and healch standards included in this or any otber chaptes o Title 296 WAC, shall be made in Writing to the director of the department of labor and industries at Olympia, Woshington, or his duly attionized representative, the supervisor of safey, division of inciustral safety and keslth, departinent of labor and industries, Olympia, Washington. Variance application forms may be obtained from the departmeat upon request." 


\section{REQUIREMENTS DENTIFICATION DOCUMENT \\ High LEVEL WASTE STORAGE TANK FARMS Occupational Safety and Healtb}

\section{HAZARD ANTICPATION, IDENTIFICATION, AND EVALUATION}

This element details the programmatic controls necessary to effectively anticipate, ideatify, and evaluate bealth and safety bazards. A programmatic approach to bazard identification/assessment, accidentinjury investigation, and hazard inventory maintenance is mecessary to successfully prevert andior

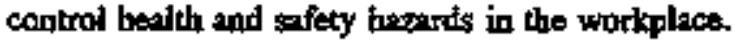

\section{Hazand Assessment Program}

This sub-dement detineates the requirements for establishing a hazard assessunent program that ensures anticipation, identification and evaluation of facility health and safety hazards. The types of hazards which sball be assessed include (but art not limited to): chemital, physical, biological, ergonomic, and safaty. A progremmntic approach to the examination and anaitysis of facility design, constnution, or modification shall be established to ensure that alt axisting or poxtential health and safexy hazards are identified. This shall also inchude the necessary controis to ensure a thorough evaluation of operational processes (including materials involved), work proctices, and empioyee working conditions.

The methods used to identify bazards in the wotkplace shal] include comprehenstve baseline surveys, periodic baseline upfats surveys, routine analysis of operational hazards, writteo hazand communication program, and periodic walk-through surveys.

Potential bazards shall be identified througb roview of proposed projects, enginterring plans and specifications; svaluation of preventotive or mitigative design features and associated administrative controls. Methods shall also be intelemented to identify and evaluate hazards following configuration changes tue to maintenance, modifications, introduction of new chemicals/wockpractices, and testing activities.

\section{FACILITY REQUIREMENT SOURCE: 29CFR1910 Part 120(b)(3)(i)}

"The comprehiensive workplan shail address anticipated clean-up ativities as well as normal operating procedures which aeed not repeat the employer's procedures available etsewhere."

\section{FACILITY REQUIREMENT SOURCE: 29CFR1910 Part 120(b)(3)(iv)}

The comprehensive workpten shall provide for the implemsentation of the training required in paragraph (c) of this section."

\section{FACILITY REQUIREMENT SOURCE: 29CFR1910 Part 120(h)(3)(v)}

The comprehensive workplen shall provide for the implementation of the required informational programs required in paragraph (i) of this section." 


\section{REQUIREMENTS IDENTIFICATION DOCUMENT HIGH LEVEL WASTE STORAGE TANK FARMS Occupational Safety and Health}

\section{FACILITY REQURRMENT SOURCE: 29CFR1910 Part 120(b)(4)(1)}

"General. The site sofely and health plan, which must be kept on site, shall address the safety and bealth hazrerds of each phase of site operation and include the requirements and procedures for employee protection."

\section{FACIITY REQUIREMENT SOURCE: S4FR3904 Part (c)(2)(0)}

"So that alt bazards are identified: (A) Conduct compreheasive beseline worksite surveys for safely and bealth and periodic comprehensive update surveys; (B) Analyze planned and new faxitities, processes, materials, ind equipment; and (C) Perform roution job hazard analyses."

\section{FACILITY REQUTREMIENT SOURCE: 54FR3904 Part (c)(2)(ii)}

"Provide for regular site safeky and health inspections, so that new or previously missed hazards and failures in bazard controls are identified."

\section{FACIITY REQUIREMENT SOURCE: 54FR3904 Part 3904.(n)(1)}

"Employers are advised and encouraged to institute and maintain in their eatablishments a program which provides systematic policties, procedures, and prectices that are adequate to recogrize and protect their employees from occupational safory and health hazards."

\section{FACILITY REQUREEMENT SOURCE: 54FR3904 Part 3904.(a)(2)}

"Ar effective progran inciudes provisions for the systematic identification, evaltation, and prevention or control of general workplace bazards, spexific job hazaids, end potentiol bataris which may arise from foreseable conditions."

\section{FACILITY REQUIREMIENT SOURCE: \$4FR3904 Part 3904.(b)(2)}

"Worksite analysis involves a variety of worksite exanninations, to identify not only existing hazards but also conditions and operaticos in whicb changes might oceut to crette hazards. Unawareaess of a bazard which stems from failure to exantine the worksite is a sure sign that safety and bealtb policies and/or praetices are ineffective. Effective management actively anaiyzes the work and worksite, to anticipate and prevent barmful occturrences."

\section{FACILITY REQUIREMENT SOURCE: DOE/EHO135 IH.2.1}

-"1. Operating procedures provide direction to ensure that potentiai hazards are identified for correction, and that industrial hygiene requiremeats are uniformly implemented."

FACILITY REQUIREMENT SOURCE: DOE/EHO135 0S.3.1

-*I. There is a documented program for identifying existing and potential 


\section{REQUIREMENTS IDENTIFICATION DOCUMENT FIGH LEVEL WASTE STORAGE TANK FARMS Occupational Safety and Health}

occurational sofoty concerns through:

- A knowledge and assessmagt of operations,

- Periodic walk-through surveys by tectinical and mparamment personnal, and

- Reviews of propased activities and modifentions to existing operations."

\section{FACILTY REQUIREMENT SOURCE: DOEJEHOL35 OS.3.2}

"2. There is a systematic program for evaluating safecy concens once they have bein identified, which includes:

- Potential safety coocerns are ovaluated to assure thoy are adequately controlled and that standaris are met,

- Gujdelines are developed for potential safety conceras if no stondard exists, and

- Written evalustions giving the conelusions on the delequacy of controls and workplace monitoring data are sent to first level supervisors.

\section{FACILITY REQUIREMENT SOURCE: DOE/EH0135 PP.I.1}

"*1. Lice managernent assures the impiententation of the personnel protection programs that effectively maintain workplaces free of health and safery concerns."

\section{FACILITY REQULREMENT SOURCE: DOEVH0135 PP.3.1}

"W1. Thtore is a documented program for juentifyinge existing and potential ocetrpational safety and heolth conceros throutgo:

- A knowledge and assessment of operations;

- Periodic walk-throngh surveys by technicil and minagement parsonne;

- Reviews of proposed activities and ondifictions to existing operstion, incluoting reviews of new or modified processes and chemicals;

- Review of purchast orders; and

- The maintenance of inventories andfor tracking systems." 


\title{
REQUIREMENTS IDENTIFICATION DOCUMENT HIGH LEVEL WASTE STORAGE TANK FARMS Occupational Safety and Health
}

\author{
FACILITY REQUIREMENT SOURCE: DOE5480.10 Section 9.a(3)
}

"Purchinsing and Contrexting Otganizations should be reçuired to: (a) participate as requested by the indestrial hygiene staff to assure that potentially bazardous material or equipment being procured are adequately ideatified, evaluated, and controlled; and (b) require contrectors or subcontrackors performing potentidly hasardous operations within = DOE or DOE-controtled facility to comply with the mandatory indistrial hygient standards of DOE 5480.4 and make provisions to allow the industrial hygiene staff to monitor compliances"

\section{FACILITY REQUIREMENT SOURCE: DOES480.10 Section 9.b(1)}

-Functions. The industrial hygiene program shall be desipand to preserve employee health and well-being. This shall be accomplished by identification. evaluation, and control of environmental factors and stresses found in the workplace. These environmental factors and stresses include: chemical (e.g., liquid, particutate, vapor, and gas); physicai (e.g., electromigntetic radiation, noiso, vibration, and magoetic fields); biological (e.g.r agents of infectious diseeses); and ergonomic (e.g., body position in relation to tusk, rapetitive motion, and moatal or physical fatigue). The contractor indistrial bygiene program must have the following features:

(1) Identification of Health Hazards. The indinstrial bygiene staff sbal] identify and document axisting and potential occupational bealth hernords through: knowledge and assessment of the operations; periodic walk-through strveys; information provided by interorganizational communication; the review of proposed projects, facilities, ongineering plan, and specifications; and muintenance of a hazards inventory or tracking system.

\section{FACLITY REQUIREMENT SOURCE: DOE5480.10 Section 9.b(2)}

"Hazand Evaluation. Once potential health hazards are identified, the industrial bygiene stoff must deternine the extent of the beyzd through appropriate consultation with other proiessionals, sound judgment, and the application of established standards or guides and such svalustion techniques as air sampling and biosssay. A report shalt be sent to the first level sopervisor with the industrial hygiene staff's evaluation of whether oscupational exposures are within permissible limits, together with supporting evidence. The permissible exposture limits used in hazand evaluation stall not exceed those in the mantatory industrial hygiente standirds of DOE 5480.4, Attachment 2, paragraph 2.d.(j). When a potential health hazard is ideotified that has oo assigned permissible exposure limit, a guideline on evaluation and control should be developed besed on the best available information (refer to paragraph 10.a.(1))."

\section{Hazard Reporting System}

This sub-efernent addresses the requirements for estabishing 2 system for employees to report workplase bazards. Employee insigbt and experience shall be utilized to quickly ideatify hazands in the workplace. Employees shall be 


\section{REQUIREMENTS IDENTIFICATION DOCUMENT HIGH LEVEL WASTE STORAGE TANK FARMS Oecupational Safety and Health}

encouraged to ideatify potential hazaris and report therd, without fear of reprisals. Management shall address employes heatth and safery concerns and reports in a timely and responsible manner.

Programmatic controls which establish a system for employees to report bazords stall, as a trinimom, spectify the methods used in the reporting process and the methinds used to ensure the confideatiality of the employen. The documentation and actions required following receipt of an employee report of a potential bazard shall be formally defined, including time response requirements.

\section{FACIITY REQUIREMENT SOURCE: 34FR3904 Part (c)(I)(iv)}

"Provide for and encourage employee involvement in the structure and operation of the program and in decisions that affect their safery and health, so that they will commit their insight and energy to achieving the safety and health program's goal and objectives."

\section{FACILITY REQUIREMENT SOURCE: 54FR3904 Part 3904,(b)(1)}

"Management commitment and employee involvement are complementary. Management commitrost provides the motivating force and the resources for organization. In an effective program, nonagerpent regards worker satety and healtb is a fundamental value of the organization and applies tis commitment to safery and besith protection with as much vigor as to other organizational purposes. Employes involvement provides the means through which workers develop andior express their own cornmitment to safery and health protection, for themselves and for their fellow workers."

\section{FACILIYY REQUIREMENT SOURCE: DOE/EH013S IH.4.7}

7. There is a system for employees to report potential occupational bealtb concerus that assures prompc assessuent and necessary controls."

\section{FACILITY REQUIREMENT SOURCE: DOE/EH0135 OS.4.8}

"8. Thers is a system for employess to report potential occupational safety concems that assures prompt assessment and necessary controls."

\section{FACILITY REQULREMENT SOURCE: DOEVE\$0135 PP.1.5}

-5. Neceseary information is revdily communicated to top managerpent, to ail serments of the organization concerned, and to the public and regulatory agencies, as approptiate."

\section{FACILITY REQUREMENT SOURCE: DOENEHO135 PP.4.8}

"B. There is a system for employees to report potentiel ofeupaticoal safery concerns that assures prompt assessment and necessary controls." 


\title{
REQUIREMENTS IDENTIFICATION DOCUMENT FIGH LEVEL WASTE STORAGE TANK FARMS Occupational Safety and Health
}

\author{
FACILITY REQUIREMENT SOURCE: DOE\$480.10 Section 9.a(5)
}

"Employees should be requitred to: (a) observe all safety and bealth rules; (b) use all prestribed persomal protective equipment; (c) follow established bealth and seffety practices and procedures; and (d) notify supervisors inmediately of surpected exposures to harmfil agents or conditions."

\section{FACILITY REQUIREMENT SOURCE: DOE5483.1A Chapter II, 1}

"a. Initially, contractor employees or representatives thereof should sftempt resolution of theis conplatiots by submitting to their contructor mongement, either directly or through their suthorized employes represeatative, reports of any conditions or practices which they consider hazardous to their safety or heslith, or which they believe ate in violation of the DOE-prescribed OSHA standards.

b. Controtor employes or their ropresentatives may submit compiaints directly to the DOE fietd organization safaty and heslth manager or the $\mathrm{CO}$ or CO representative, particularly in siluations where the complainant wishes to remain inonymous (to the contractor), or where the comptainint belioves that unsafe/unhealthful conditions still exist or violations of standands still remain after being brought to the attention of and addressed by contractor management.

c. Complaints may be submitted to either contractor management or to the DOE by completing DOE F 5480,4 (Attachment II-1), by sending a letter or telegram, ar by oral means. Orat complaints stall be recorded on DOE F 5480.4 by DOE ind/or the contrictor. lirespective of the means of submission, the complaint should set forth with reasonable particularity the pertinent facts and circupsstances involved. In alt situations where the complaint is submitted to DOE and anonymity is requested by the conplainant, the DOE shall not divulge the complainant's ideatity to contractor personntol or to any other persons not essential to the processing and investigation of the complaint."

\section{FACIIITY REQURREMENT SOURCE: DOE5483.IA Chapter I, Section 5}

"5. COMPLAINT RESOLUTION. Contractor employees or representatives thereof who are not satisfied with the arlequacy or effectiveness of the fiedd organization's investigation of or response to their cordpiaint allegations may submit a written request for complaint resolution to the Director of Operational Safety (EP-32). The request must include the pertinent faets and particulars, and the basts for the request (e.g., inadecuate action taken on violation of a standard, or no employee or representative allowed to partictpate in inspection), along with a copy of the original compotinint and the field organization's response thereto. EP.32 shall conduct 24 investigstion of the sikuation, in coordination with the appropriate program offices(8). Within 30 days of receipt of the request, EP-32 shall provide a written response to the employee or representative thereof, and to the field organization. The response shall indicate the actions taken or planned as a result of the request for complizint resolution." 
WHC-EP-0750

\section{REQUIREMENTS IDENTIFICATION DOCUMENT HIGH LEVEL WASTE STORAGE TANK FARMS Occupational Safety and Health}

\section{FACILITY REQUIREMENT SOURCE: DOES483.1A Chapter III, 1}

\section{NONDISCRMMINATION.}

a. No contractor shall discharge or in any manner demote, reduce in pay, coerce, restrain, threaten, or cake any other negative actions agxinst any contractor employes as a result of the employee's filing of a complatint, or in any other fashion, exercisinit on bebalf of hinself or berself or others any rigbt set forth in this Orter.

b. Any employes who believes be or she bas been discharged or in nay atber minnor diseriminated agaisst, is vialstion of this Order, may file a complaint with the cogrizant $\mathrm{CO}$ or $\mathrm{CO}$ representative within 30 days after the altised discrimination, setting forth the gature of the alleged discrimination. The $\mathrm{CO}$ or $\mathrm{CO}$ representalive, the safoty and bealth dirsetor, and othor appropriate oiements of the fietd organization shall investigate the complaint, and if it is tound that such discrimination has occurred, the field organization sbal] assure that appropriate messures are taken by the contractor, including rehiving or reinstatement of the employee, restocation of lost seniority, and back pry. The field organization shall report the disposition of the matter to the contractor empioyes filing the complaint of alleged discrimination within 30 days after recejpt of the complaint."

\section{Investigntion of Occurrences, Accidents, and Neir Misses}

This sub-element addresses the requirements for establishing a program for investigation of occurrences, accidents, and near misses for identification of potential health and safety concens. Programmatic controls sball be tablizhed to ensure that a comprehensive root cause analysis is performed and that appropiate corrective actions are identified following events such as an occurrence, accident, or daar míbs. Sucb controls are essentiaj if bealth and safecy hazands ane to be effectively identified and corrected following significant events.

The Occurresce/Event Reporting section of the Management Systerns Functional Arte describes the requirements and controls necessery for an effective Occurrence/Event Reporting program. The Health and Safely organization should participate in the investigation and evaluation of events wich are addressed by that functional area.

\section{FACILITY REQUIREMENT SOURCE: 54FR3904 PArt (c)(2)(jv)}

"Provide for investigation of socidents and "near mitss" iretidents, so that their causes and means for their prevention ate identified."

\section{FACHITY REQUIREMLNT SOURCE: DOE/EH0135 IF.4.2}

"2. Investigations ate conducted for incidents and ovents that resolted or could have restlted in occupational illness, or death to jdentify probable causes and judgment of needs to prevent recurrence of similar accidents, in complience with DOE 5484." 


\title{
REQUIREMENTS IDENTIFICATION DOCUMENT HIGH LEVEL WASTE STORAGE TANK FARMS Occupational Safety and Health
}

\section{FACILITY REQUIREMENT SOURCE: DOE/EH0135 0S.4.2}

\begin{abstract}
-2. Accident investigations are conducted for incidents and everts that resulted or could have resolted in oceupational injuries of death, to identify probable cinses and judgernent of needs to preveat recurrence of similat accidents."
\end{abstract}

\section{FACIIITY REQUIREMENT SOURCE: DOEJEHO135 PP.4.2}

"*2. Accident investigations are conducted for incidents and avents that resulted or could have restited in oceupationsl injuries, illoss, or death to ideutify probable censes and juigement of oeds to preveat recurrence of sintilar accidents."

\section{FACILITY REQUIREMENT SOURCE: DOES483.1A Chapter III, 4}

*4. ACCIDENT, INVESTIGATIONS. Accident investigations shall be cooducted in accordance with DOE 5484.1, ENVIRONMENTAL PROTECTION, SAFEIY, AND HEALTH PROTECTION INFORMATION REPORTING REQUIREMENTS, of 2.24.81."

\section{Iniucyand_llgess Trend Anolysis}

This sub-element detineales the requirements for estoblisting a trend analysis program to docurment and track injuries and illnesses for possible hazard identifiestion/correlation. Evaluation of recurring oceupational injuries and illnesses is essentiat in identifying workplace bealth and safery bazaris. Programmatic controls sball be instiłuted that define methods for collection and analysis of occtupational injury and illness data. The Oocupational Medical Program shall be a key participant in the aceurate identification, evaluation, and collection of occupational injury and illness data.

\section{FACIITY REQUIREMENT SOURCE: 54FR3904 Part (c)(2)(v)}

"Analyze injury and illoess trends over time, so that parterns with common canses can be identified and prevented."

\section{FACILITY REQUIREMENT SOURCE: DOE/EHO135 İ.4.6}

6. Analyses of industrial hygient monitoring dats are performed to evaluate performance and identify treods and potential problem areas to be brought to managenent alteotion."

\section{FACHITY REQUIREMENT SOURCE: DOE/EH0135 0S.4.7}

7. Analyses of accident and injury data are performed to evaluate performance and idendify trends and potential problem areas to be brought to management attention." 


\section{REQUIREMENTS DENTIFICATION DOCUMENT HIGH LEVEL WASTE STORAGE TANK FARMS Occupational Safety and Health}

\section{FACILITY REQUIREMENT SOURCE: DOEEFH0135 PP.4.7}

-7. Analyses of accident, injury, and indastrial hygitue monitoring data are performed to avaluate performance and ideatify trends and potential problem areas to be brought to management attention."

\section{FACIITY REQUIREMENT SOURCE: WAC-296-24 Section 020(2)}

"After the emergency actions following accidents that cause serious injuries that have immediate symptoms, a preitiminary investigation of the cause of the accident shall be conducted. The investigation shall be condueted by a person desigalted by the employer, the immediate supervisor of the injured employe, witnesses, employee representative, and any other person with the special expertise required to evaluate the facts relating to the calse of the accident. The findings of the investigation shail be documented by the employer for reference at any following formal investigation. If the employe representative is the business ageat of the employee bargaining unit that is ungvaitabie to participate without delaying the investigation group. the employer may procesd, and satisfy the requirements of subsection (2) of this section by using one of the following alternatives:"

\section{Oceupartional Safety and Hentth.Inventory Srstem}

This sub-edement delineates the requirements for establishing 2 health and safety hazard inventory systen. The hazards identified via the methods described in the previous sub-elements (17.2.1 through 17.2.4) shal] be inpult to a hazard inventory system.

Continusous maintenance of the hazard inventory system is necessary to ensure that identified hazards are eliminaled/mitigated, properly documented and tracked to prevent undue hazard exposure or consequence. The system shall maintain a corretation of potential hazards by location, assoctated processes, and job classifications/categories. The controls necessary to manage a comprehensive bazard inventory syster,, including update or revision. shall be established.

Proper implementation and use of a hazard inventory system shal] provide the basis for selection of eontrols to linuit hazand exposure, detemination of medical surveillance requiresbents, location of montoring/ssmpling equipment, or the determination of employee training requirements.

\section{FACHITY REQUIREMENT SOURCE: 29CFR1910 Part 120(c)(2)}

"Preliminary evaluation. A preliminary evaluation of a site's characteristics shall be performed prior to site entry by a qualified person in order to aid in the selection of appropriate employee protection methods prior to sito entry. Immediately after initial site entry, a more detailed evaluation of the site's specific cbaracteristics shalt be performed by a qualified person in order to further jdentify existing site hazants and to further aid in the selection of the appropritate engineering controls and persomal protective equipineat for the casks to be performed." 


\section{REQUIRRMENTS IDENTIFICATION DOCUMENT HIGH LEVEL WASTE STORAGE TANK FARMS Occupational Safety and Health}

\section{FACIIITY REQUIREMENT SOURCE: 29CFR1910 Part 120(c)(3)}

"Site Characterization. Hazard identification. All suspected conditions that may pose inhalation or skin absorption hazards that are immediately daggerous to life or bealtb (IDLH), or other conditions that may casuse death or zerious barm, shall bo identified during the prelimintary . survey and evaluated during the detalled survey. Examples of soesh hazards ioclude, but are not linited to, confined space entry, potentially explosive or flammable situations, visibile vapor clouds, or areas whore biological indicators such as dead animals or vegetotion ara located."

\section{FACILITY REQUIREMENT SOURCE; 29CFR1910 Part 120(c)(4)}

"Required information. The following information to the extent available shall be obtained by the employer prior to allowing employees to enter a site:

(t) Location and approximate size of the site.

(ii) Description of the response activity and/or the job task to be performed.

(iii) Duration of the planned exployee activity.

(iv) Site topography and accesstbility by air and rosis.

(v) Safoty and health bazarde expected at the site.

(vi) Rathways for hazardous substance dispersion.

(vii) Present stolus and capabilities of emergency response teams tbat would provide assistance to hazardous waste clesn-up site employees at the time of an emergepey.

(viii) Hazardous substances and bealth hazards involved or expocted at the site, and their chemital and physical properties."

\section{FACILITY REQUREMENT SOURCE: ANSI-ZZ14.1-1982 Section 4.1}

"An initial survoy shall be made to idantify all energy sources and related exposures to determine if machines, equipment and systens can be isclated."

\section{FACILITY REQUIREMENT SOURCE: DOE/EHO135 PP.2,9}

4 9. A formal program is established to track the correction of identified deficiencies and deviations from preseribed standards."

\section{FACLITY REQUUREMENT SOURCE: DOES490.10 Section 9.f(1)}

-Recordkeeping Requirements

(1) An inventory of occupational health hazands shall be maintainec. The inventory should be a listing of poential chenical, physical, and biological health hazarits by location andior job category of users and indicate when the hazards were prestent."

\section{FACח.ITY REQUIREMENT SOCRCE: DOE5480.10 Section 9.f(5)}

"Industrial hygiene hazard inventories, reports, and monitoring data shall be feadily accessible to the medical organization responsible for operating the medical monitoring program. Records acesss sball be provided to employees or designated represertatives of employees in accordance with OSHA Regulation 29 CFR 1910.20 and DOE Privacy Act Regulation to CFR 1008.17(b)(5).- 


\section{REQUIREMENTS DENTIFICATION DOCUMENT HIGH LEVEL WASTE STORAGE TANK FARMS Occupational Safety and Health}

\section{OS\&H HAZARD PREVENTION AND CONTROL}

This edement contains sub-elements which define the programmatic controls neceseary to implemient appropriate health and sofecy prevention and control measures. Proper application of the following sub-elements is neceseary to prevent or control identified and evaluated hazords.

FACILITY REQUREMENT SOURCE: 29CFR1910 Part 120(b)(4)(1)(A)

"Elements. The site safety and bealth plar, as a minimum, shall address the following: A safety and hegith risk or bonard andysts for each site task and operation found in the workplan."

\section{FACILITY REQUIREMENT SOURCE: DOEJEHO135 IH.5.11}

"11. Exposures to beat stress conditions conforms to the guidelines of the American Conferense of Governmental Industrial Hygienists."

\section{EACIIITY REQUIREMENT SOURCE: DOE/EH0135 LH.5.2}

"2. Hazardous noise is coptrolled in wecordance with ACGIH TLVs and the hearing conservation program complies with 29 CFR 1910.95."

\section{FACI,ITY REQUIREMENT SOURCE: DOE/EH0135 IH.5.3}

-*3. Exposure to chemicals listed as careinogens by the ACOIH or OSHA are maintained ALARA by applying controls required by standards in 29 CFR 1910 Subpart $Z$ or criteria ia DOE 5480.10."

\section{FACILTY REQUIREMENT SOURCE: DOEJEH0135 IH.5.5}

- 5 . Procedures used for working in confined spaces connply with 29 CFR 1910-146, Junt 5, 1989."

\section{FACILITY REQUIREMENT SOURCE: DOE/EH0135 IH.5.6}

-"6. Hazardous waste bandling operations and hazardous material emergency response operations comply with 29 CFR 1910.120."

\section{FACILITY REQUIREMENT SOURCE: DOE/EH0135 IH.5.9}

\footnotetext{
"*9. A documented respiratory protection program, complying with ANS1 Z88.2. 1980, has been implemented to ensure optimum protection against internal exposure of workers to toxic meterials, incloting radioactive substances."
}

\section{FACILITY REQUIREMENT SOURCE: DOEJEH0135 IH,6.I}

"*1. All bazarilods chemicals aro sppropriatedy lateled." 
HAC-EP-0TS0

\section{REQUIREMENTS IDENTIFICATION DOCUMENT HIGH LEVEL WASTE STORAGE TANK FARMS Occupational Safety and Health}

\section{FACLITY REQUIREMENT SOURCE: DOEHHOL3S M:.6.2}

- 2. Material safety deta sheets for all hazartous chemicals are readily available. Distribution is appropriate for those who need the information."

\section{FACILITY REQUIREMENT SOURCE: DOEJEHT135 TH.6.8}

78. Procedural reminders are posted Jocally (e.,e, "Hearing Protection Required")."

\section{FACILITY REQUIREMENT SOURCE: DOE/EHOL35 OS.2.1}

"*1. Operating procedures provide direction to ensure that potential safery concerns are identified for corrsction, and that safety requirements are uniforrily impilemented."

\section{FACILITY REQUREMMENT SOURCE: DOEJEHD135 OS.2.5}

-5. Work ptrmits identify potentially hazardous maintenance, construction, experiments, and other con-routine activities and assore the appropriate application of safety expertise to plenping and review of the work."

\section{FACIITY REQUIREMENT SOURCE: DOE/EH0135 WS.3.6}

**6. Hazardous waste handling operations and hazardous material emergency response opecations comply with 29 CFR 1910.120 .

\section{FACXITY REQUTREMENT SOURCE; DOE/EH0135 WS.3.8}

48. Cherrical handling operations comply with applicsble OSHA standards 29 CFR 1910.1000 through 1910.1048."

\section{FACIITY REQUUREMENT SOURCE: DOE/EH013S WS.4.11}

"11. There are safety rules and requitements for the use of motorized equipment and motor vehickes. Personnel understand and comply with the nules:-

\section{FACILITY REQUIREMENT SOURCE: DOENEH0135 WS.4.13}

-13. Weiding, cutting, and brazing operations ane conducted in acrordance with 29 CFR 1910 Subpart Q."

\section{FACILITY REQUIREMENT SOURCE: DOE/EHO133 WS.4.15}

"15. Telecommunications, and laundry machinery and operations met the requirements of 29CFR19]0 Subpart R." 


\section{REQUIREMENTS IDENTIFICATION DOCUMENT HIGH LEVEL WASTE STORAGE TANK FARMS \\ Occupational Safety and Health}

\section{FACILITY REQURRMMENT SOURCE: DOEJEH0135 WS.43}

*3. Ladders, guard cails, and fall protection equipment are well-maintained and meet standards prescribed in 29 CFR 1910, Subpart D."

\section{FACILITY REQUIREMENT SOURCE: DOEMAHAL 35 WS.4.5}

" 5. Exits are properly marked, adequately ligited, and all means of egress are continuous and unobstructed to a way of exit from aby point in a building in accortinnce with 29 CFR 1910, Subpart E.-

\section{FACILTY REQUIREMENT SOURCE: DOE/EH0135 WS.5.1}

**1. There are appropriate danger, warning, and safery information signs throughout the sice in accordance with 29 CPR 1926, Sultpart G."

FACILITY REQUIREMENT SOURCE: DOEJEH013S WS.5.10

"10. Thers ace safety rules and reciuirements for the use of motorized equipurent and motor vehicles. Personned understind and comply with the rules."

\section{FACILITY REQUIREMENT SOURCE: DOE/EH0135 WS.5.11}

"*11. Chemical, physical, and biological stresses to construction workers are adequately controlled in aceordance with 29 CFR 1926, Subpart D."

\section{FACHITY REQUIREMENT SOURCE: DOE/EH0135 WS.5.13}

- +13 . Chemical handling operations coonply with applicable OSHA standards 29 CFR $1926.55,1926.57$, and 1926.58."

\section{FACIITY REQUIREMENT SOURCE: DOE/EH0135 WS.5.3}

"*3. Leiders, guard rails, and fall protection equipment are well-maiatained and meet standards prescribed in 29 CFR 1926, Subparts E, L, and M."

\section{FACILITY REQUIREMENT SOURCE: DOEJEH0135 WS.5.4}

- 4. Guarding is avaitable and in Wace, as spectified in 29 CFR 1926, Subpart 1, for machines and tools with moving and rotating parts that may present workplace stfety concerus."

\section{FACILITY REQUIREMENT SOURCE: DOEIEH0135 WS.59}

" 9. Persoxinel are aware of and follow procedures for lockout and tagout to prevent accidental contact with energized olectrical circuits and ocher hazerdous mergy sources, in accordance with 29 CFR 1926, Subpart K." 


\section{REQUIREMENTS DENTIFICATION DOCUMENT HGH LEVEL WASTE STORAGE TANK FARMS Occupational Safety and Health}

FACIITY REQUIREMENT SOURCE: DOE/EH0135 WS.6.1

"H1. Hazardous chemicals are appropriately labeled."

\section{FACILITY REQUIREMENT SOURCE: DOEJEH0135 WS.6.2}

-*2. Moterial safely data shets for hazardous cbemicals are readily available. Distribution is appropriate for those who ned the information, and in accontence with 29 CFR 1910.1200, and 29 CFR 1926.5".

\section{FACILITY REQUREMIINT SOURCE: DOE/EHO135 WS.6.7}

7. Procedural reminders are posted locally (e.g., "Fire Door-Keep Closed At All Times")."

17,3.1 Facillty, Hozared Monitoring, Sampling, and Surveillance

This sub-element addresses the requirements for establishing programmatic contcols that ensurte adequate monitoring and sampling of identified bealth bazands is performed. Monimoring and sampling of identified beatth hazards shall be performed where the potential exists for expiloyee exposire. The results of an offective monitoring and sampling program fucilitates the selection of proper engineering controls, administrative controls, and/or persongat protective equipment.

\section{FACILITY REQUIREMENT SOURCE: 29CFR1910 Part 120(b)(4)(i)(E)}

The site safery and bealth plan, as a minimum shall address the foilowing: Frequency and types of air montoring, personnel montoring, and environmental sampling techniques and instrumentation to be used, including methods of maintenance and calibration of monitoring and sampling equipmeat to be used."

\section{FACILITY REQUIREMENT SOURCE: 29CFR1910 Part 120(c)(1)}

"Sitte charzettrization and analysis, General. Hazarcious waste sites shall be evaluated in accordance with this paragragh to identify specific site hazards and to deternitine the appropriate safety and health control procedures needed to protect amployees from tist identīīed bazards."

\section{FACILITY REQUIREMENT SOURCE: 29CFR1910 Part 120(c)(6)}

"Monitoring. The following monitoring shall be condacted during initial site entry when the site evaluation prodtaces information that shows the potential for fonizing radjation or IDLH conditions, or when the site information is not suffieient reasonably to elintinate these possibje conditions;

(j) Monitoring with direct reading instnuments for bazardous levets of jonizing radiation.

(ii) Monitoring the air with appropriate direct reading test equipment (i.o., combustible gas meters, detector tubes) for IDLH and other conditions that may cause death or serious harm (combustible or explosive atmospheres, oxygen deficiency, toxic substances).

(iii) Vistually observing tor signs of actual or potential BDLH or other dangerous conditions. 


\section{REQUIREMENTS IDENTIFICATION DOCUMENT HGGH LEVEL WASTE STORAGE TANK FARMS Occupational Safety and Health}

(iv) An ongoing air monitoring program in accordance with paragraph (b) of this section shalt be implemented after site charaterization has determined the site is gafe for the startup of operations."

\section{FACILTTY REQUTREMENT \$OURCE: 29CFR1910 Part 120(h)(1)(i)}

"Monitoriugs,

Genersl. Monitoring shall be performed in accordance with this paragrapb where there may be a question of empioyee expostre to hazardous concentrations of hazardous substances in order to assurte proper selection of enginesring controls, work practices and personal protective equipment that employees are not exposed to tevels which exceed permissible exposure limits, or publisked exposure levels if there are no permissible exposure limits, for harardous substances."

\section{FACILITY REQUIREMENT SOURCE: 29CFRI910 Part 120(h)(2)}

"Initial entry. Upon initial entry, representative air monitoring shall be conducted to identify any IDLH condition, exposure over permissible exposturs limits or pablished exposure levels. exposure over a radioactive material's dose limits or other dangerous condition such as the presence of flammable atmospheres or axystm-deficjent environments."

\section{FACILITY REQULREMENT SOURCE: 29CFR1910 Part 120(h)(4)}

"Monitoring of high-risk employees. After the actual clenn-up phase of acy bazardous waste operation commences; for example, when soil, surface thater or containers are asoved or disturber; the employer shall monitor those swployees likely to bave the highest exposures to hazardous substances and health hazards likety to be present above permissible exposure limits or fublistued exposure levels by using personal sampiting frequenty enough to tbaracterize employes: exposures. If the errployees likely to have the highest exposure are over permissible exposure Iimits or published exposure limits, then monitoring shall continue to determine all employeer likely to be above those limits. The amployer may utitize a representative sampling approsech by docuraenting that the enployees and chemicals chosen for monitoring are based on the criteria stated above.

Note to (h): It is not required to monitor employees engaged in site characterization operations covered by paragraph (c) of this section."

\section{FACILITY REQUIREMENT SOURCE: DOEJEH0135 PP.3.5}

"5. Monitoring data are regularly obtained for potential heslth and sefery concerns and the information is utilized in determining the effectiveness of control measures."

\section{FACILITY REQGIREMENT SOURCE: DOEJEH0135 PP.4.4}

- 4. There is a documented program for periodic monitoring of cbemical, physical, and bjological stresses to ensure maintenance of satisfactory conditions. Surveillance manitoring ensures that potential persoanel expostires are accurately delermined and recorded. Monitoring results which evaluate the continuing adequacy of controls arte sent to line managentent and employees on a coutine basis. 


\section{REQUIREMENTS IDENTIFICATION DOCUMENT HIGH LEVEL WASTE STORAGE TANK FARMS Occupational Safety and Health}

\section{FACILITY REQUIREMENT SOURCE: DOE/EH0135 WS.2.1}

-*1. There is health and safety surveillance of all construction activities."

FACILITY REQUIREMENT SOURCE: DOE5480.10 Section 9.12(2)

"Hazord Evaluation. Once potential bealth hamards are ideutified, the incustrial hygiene steff wost determine the extent of the bazard through appropriate consaltation with other professionels, sound juxdgment, and the applitation of estabitished stendards or guides and such evaluation techniques as air sampling and bioassay. A report shall be sent to the first level stopervisor with the industrizl hygtents staff's evaluation of whether occupational expostres are within permissible limits, together with supporting ovidence. The permissible exposure limits used in hazard evaluation shell not

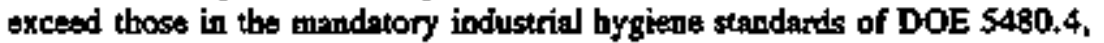
Attachment 2, paragraph 2.d.(3). When a potential bealth hagard is identifited that bas no assigned permissible exposure lintit, a guideline on evaluation and coratrol should be developed based on the best available information (rofer to paragraph 10,a,(1))."

\section{FACILITY REQUIREMENT SOURCE: DOE5480.I0 Section 9.b(4)}

"Periodic Review. The setisfactory controd of oceupational health hazards shall be given continuing attention despice the imposition of control messures. Periodic monitoring is essential to assure minintenence of satisfactory conditions. The industrial bygiene staff shalt determine the type and frequency of periodte monitoring. The industrial hygiente staff shall report to lime mapagement regerding the continuing adequacy of controls, the need for additional cantrols, or recommendations for maintenance or remphasis of administentiva controls. Employees of DOE coutmactor organizations shatl be provided the results of the monitoring program for toxic materials or harmful physical ageats, upon request."

\section{FACILITY REQULREMENT SOURCE: DOE5483.1A Chapter I, Section 5.d}

"Alt contractor employess shall be informed that the contractor is rexuired to monitor the exployes's workplace for radiation exposure and known toxic materials or hamiful physical agents which are used or produced at the GOCO facility, and to maintain reconds of the data as required by Title 29 CFR Part 1910.20, "Access to Employee Exposure and Modical Records. " Employees or their anthorized representatives are to be provided with an oppornunity to abserve montitoring or measturing for toxic materials and barmful physical agents and to bave acess to the results thereof. Fach etoplayee or tormer employee or representative theseof, within 15 days of a written request, shall be provided access to or copies of any records of cumulative reconded cocupational radiztion dose or any monitoring or bioassay reconds relovant to potential exposure to toxic materials or hermful pbysical 2gents during encployment. Employees will be notified of any information indicating that a radiation dose or an exposure to toxic materials or farturiol pbysical agents may have exceeded the Iinuts specified by the DOE-pressribed OSHA standards." 


\section{REQUIREMENTS IDENTIFICATION DOCUMENT HIGH LEVEL WASTE STORAGE TANK FARMS Occupational Safety and Health}

This sob-element addresses the requirtments for developing and implementing engineering controls for prevention and/or control of identified hazards. Engineering controls shall be applied where there is a potential for employee exposure and shall be the preferred meshod of basard prevemtion and control. in the event that engineering controls are infeasible or too costly then administrative controls and/or personal protective equipinent shall be used tor bazard prevention and control. Additionally, some situtitions warrat that all, or a combination of, the above listed controls may be necessary to satisfactory control the hazard.

Speciffeally, the methods for selecting and evaluating the effectiveness of designed engipeering controls shall be defined. Proper documentation siall be maintained of the selection, use, and evaluation of engineering controls for new projects, facilities, and processes.

The selection, design, and use of engineering controls shall be accomplished in accordiance with Engineering Design Program procedures. The Engineering Destgn Functional Area outlines the programmatic controls necessary to govern this activity.

\section{FACILITY REQUIREMENT SOURCE: 29CFR1910 Part 120(g)}

'Engtheering controls, work practices, and personal protective equipment for employee protection. Engineering conirols, work practices, personal protective equipmeat, or a combinztion of these shall be implentented in accordance with this paragraph to protect employees from exposure to bazardous substances and sately and health hazards."

\section{FACILITY REQUIREMENT SOURCE: 29CFR1910 Part 120(g)(1)(i)}

"Engineering controls, work practices and PPE for substantes regulated in suhparts G and Z. Eaginearing controls and work practices shall be instiruted to reduce and maintain employee exposure to or below the permissible exposure limits for substances regulated by $29 \mathrm{CFR}$ part 1910, to the extent required by sulpost Z, except to the exient that such controls and practices are not feasible."

\section{FACILITY REQUIREMENT SOURCE: 29CFR1910 Part 120(g)(1)(ii)}

Whenever enginesring controis and work practices are not feasible or not required, any reasonable combination of engineering controls, work pratices and PPE shall be used to reduce and maintain employee exposures to or below the permissible exposure limits or dose limits for substances regulared by 29 CFR part 1910, subpart Z.

\section{FACILITY REQUIREMENT SOURCE: 29CFR1910 Part 120(g)(2)}

"Enginetring controls, work practices, and PPE for substances not regulated in sub parts $G$ and $Z$. An appropriate combination of enginesring controls, work prectices and personal protective equipment shall be used to reduce and maintain enpioyee exposure to or below published exposure levels for bazandous substances and health hazands not regulated by 29 


\section{REQUIREMENTS IDENTIFICATION DOCUMENT HIGH LEVEL WASTE STORAGE TANK FARMS Occupational Safety and Health}

CFR part 1910, sub parts $G$ and $Z$. The employer may use the published literature and MSDS as a guide in making the employer's determination as to what level of protection the employer believes is appropriate for bazardous substauces and bealth hazards for which there is ao permissible exposure limit or pablished exposure limic"

\section{FACILITY REQUIREMENT SOURCE: 29CFRI910 Part 147(c)(5)(0)}

"Lockout and Tagout

(i) Lokks, tags, chains, wedges, key blocks, adapter pins, selt-locking fasteners, or other hasdware shall be provided by the employer for isoleting, securing or blocking of mwchines or equipment from energy sources."

\section{FACILITY REQUIREMENT SOURCE: 29CFR1910 Part 147(c)(5)(ii)(A)}

\section{"Lockout and Tegout}

(ii) Lockont devices and target devices sball be singularly ideatified; sball be the only devices(s) used for controlling energy; shall not be used for ather purposes; and shall meet the following requirements: (A) Duroble (1) Lockout and thgoot dovices shall be capable of withstanding the environnitent to which they are exposed for the maximum period of time that exposure is expected. (2) Tagout devices shall be constructed and printed so that exposure to weather conditions or wot and damp locations will not cause the tag to deteriorate or the wasesge on the tag to become ilegible. (3) Tags sball at deteriorate when used in comosive environments such as areas where actid an alkali chomicals are handled and stored."

\section{FACILITY REQURENENT SOURCE: 29CFR1910 Part 147(c)(5)(ii)(B)}

"Lockout and Tagout

(B) Stundardized. Lockout and tagout devices shall be standardized within the facilty in at teast one of the following criteriat color; shape; or size; and additionatly, in the cas tagout devices, a print and format shatl be standardized."

\section{FACIITY REQUIREMENT SOURCE: 29CFR1910 Part 147(c)(9)(ii)(C)(1)}

"Lockoat and Tagout

(C) Sulastantial-(i) Lockout devices. Lockout devices shall be sutostaptial enough to prevent removal without the use of exessive force or unuguel tecthigiues, such as with the use of bolt cutters or other motst cutting tools."

\section{FACILITY REQUIREMENT SOURCE: 29CFR1910 Part 147(c)(5)(ti)(C)(2)}

\section{"Lockont and Tagout}

(C) Substantial-(2) Tagout devices, including aod their meacs of attricimeat, shall be substantial enough lo provent intidvertent or accidental removal. Tagout device attachment means shall be of a non-reusabie type, attachable by band, self-locking, and non-releasable with a minimmu unlocking strength of no less than 50 pounds and having the general design and basic characteristics of being at least equivalent to a one-piece, all-environment-tolerant oyloo cable tie." 


\title{
REQUIREMENTS IDENTIFICATION DOCUMENT HIGH LEVEL WASTE STORAGE TANK FARMS Occupational Safety and Health
}

\author{
FACILITY REQUIREMENT SOURCE; 29CFR1910 Part 305 (j)(4)(i).
}

"Wiring methods

Disconnectidg means. A disconmecting means sball be located in sight from the controlter location. However, 2 singie discommecting means may be located adfacent to a group of coordinated controtlers mounted adjacent to each other on a multi-motor continuous process machine. The controller disconnecting means for motor branch circuits over 600 volts, nominal, may be out of sight of the controller, if the controller is marked with a warning label giving the location and identification of the disconnecting means which is to be locked in the open position."

\section{FACILITY REQUIREMIENT SOURCE: 29CFR1919 Part 333 (c)(10)}

"Selection and use of work practices

(10) Interlocks. Only a qualitied parson following the requirements of paragrapt (c) of this section may defeat an dectrical safety interlock, and toen only temporarily while be or she is working on the equipment. The interlock system shall be renumed to its opersb]e condition when this work is completed,"

\section{FACILIFY REQUIREMENT SOURCE: 29CFR1910 Part 333 (c)(d)(l)}

"Selection and use of work practices

(4) Ithumination (i) Employees may not enter spaces containing exposed energized parts, unjess illumination is provided that ensbles the entoloyes to perform the work sofely. (ii) Where lack of illumination or an obstruction precludes observation of the work to be performed, amployees mizy not perform tasks near exposed energized parts. Employess may not reacb blíndly into areas which may contain energized parts."

\section{SITE REQUTREMENT SOURCE: 29 CFR1910 Section 305 (0)(4)(ii)(C)}

"If a motor and the driven mehinery are not in sight from the controller location, the installation stall comply with one of the following conditions:

(1) The controiler disconnecting means sball be capabie of being locked in the open position.

(2) A manualily operable switch that will disconnect the motor from its soures of supply shal] be placed in sight from the motar lowation."

\section{SITE REQUTREMENT SOURCE: 29CFR1910 Section 305 (j)(4)(ii)(D)}

"The disconnecting means shall plainly indicate whetber it is in the open (off) or closed (on) postition."

\section{FACHITY REQULEEMENT SOURCE: ANSI-Z244.1-1982 Section 4.3}

-Selection and Procurement of Protective Materials and Handwarte.

The requirements for togs, ebains, locks, adapters, pins, and the like stould be as retained and an adequate strpply be maintained, distributed, or assigned as needs dictate. Lockont/tagout devices statl be of a distinctive design and appesrance and be used solely for the purpose of providing personnel protection.- 


\section{REQUIREMENTS IDENTIFICATION DOCUMENT HIGH LEVEL WASTE STORAGE TANK FARMS \\ Occupational Safety and Health}

\section{FACIIITY REQUIREMENT SOURCE: ANSI-Z244.1-1982 Section 5.1.2}

"Lockout/tagout of energy sources

Equipment Access and Reicase. A method shall to establisted to provide a means of gaining access to the equipment/process that involves acirowiedgement and release from use by the individual(s) respoasible for the equipment/process.

\section{FACILITY REQUIREMENT SOURCE: ANSI-Z244.1-1982 Section 5.1.3}

-Plan.

Where equipment/prosess complexity or other copditions warrant, a lockout/agout plan should be developed to serve is a control measure for the duration of the job."

\section{FACILITY REQUIREMENT SOURCE: DOE5480.10 Section 9.c(4)(c)}

"Engineering controls shall be the primary method used to minimize exposure to carcinogens and to prevent the release of carcinogens into the workroom environment. Provisions shall be made to assure that hazardous levels of contaminated air are not rejezsed intn adjecent work areas or the cultside environment. All contaminated liquid and solid waste shall be disposed utiltzing approved methods (refer to DOE 5480,4, Altachment 1, parzigraph 2.b.(11))-"

\section{STTE REQUIREMENT SOURCE: WHC-SP-0708 Chapter 8, Section 5.3}

-Aligument checks siatil be performed after exteaded sbutdowns, matulenance, or «s defined by other procedures."

\section{FACILITY REQULRZMENT SOURCE: WHC-SP-0708 Chapter \&, Section 5.3} paragraphs 1 and 2

"Locking devices shail be used on those' comppnents over which special administrative control mtst be established. Paragraph 2 - Locking devites provide some security that a component witl be operated only by zuthorized facility personnel performing required evolutions in a controlled teshion. Additionally a loxking device should alert the operator of the importance of the component and remind the operator that special controis over repositioning are to be maintained. In this respect, atl persmnttl should rexeive training regarding their reponsibilities concerning the manipulation of locked components."

\section{Administrative Controls}

This stro-element addresses the requirements for establishing and implementing administrative controls. Administrative controls may be applied where engineering controls are insufficient or imprattical to effectively limit hazard exposure. In some sinutions, a combination of engineering controls, administrative controls, and/or persongi protective equipment may be necessary to effectively limit hazard exposure.

The methodology for selecting and evaluating the effectivenes of administrative controts shall be ctearly defined. The selection, use, and 


\section{REQUIREMENTS IDENTHFICATION DOCUMENT HIGH LEVEL WASTE STORAGE TANK FARMS \\ Occupational Safety and Heaith}

evaluation of administrative controls shall be property docomented.

Administrative controls stall be procedaralized in accordince with the controls ideatified in the Policies and Procedures section of the Manggement Systems Functional Area.

\section{FACILITY REQUREMENF SOURCE: 29CFR1910 Part 120(b)(1)(ii)}

-Site excavation. Site excavations created during initial site prepatation of during hazarious wasta operztions shail be shored or sloped as appropriate to prevent accidental collapse in accordance with stispart P of 29 CFR part 1926."

\section{FACILITY REQUIREMENT SOURCE: 29CFR1910 Part 120(b)(4)(j)(G)}

"The site safety and health plan, as a minirmur shail address the following: Decontamination procedures in accordance with paragraph $(k)$ of this section."

\section{FACILITY REQUIREMENT SOURCE: 29CFR1910 Part 120(b)(4)(ii)(F)}

"The site safoty and healih plan, as a miniaum shall address the following: Sito control measures in accordance with the site control program reguired in paragraph (d) of this section."

\section{FACIIIY REQUIREMENT SOURCE: 29CFR1910 Part 120(b)(4)(ii)(I)}

The site safety and heatth pitan, as a miaimutal sheil address the following: Confined space entry procedurss."

\section{FACILIYY REQULREMENT SOURCE: 29CFR1910 Part 120(b)(4)(ii)(J)}

"The sice safecy and healib plan, as a minimoun stall address the following: A spill containment program mesting the requirements of paragrapls $(0)$ of this section."

\section{FACILITY REQUIREMENT SOURCE: 29CFR1910 Part 120(b)(4)(tii)}

The site sofery and heatth pian, 25 a minimum stail address the following: Pre-entry briefing. The site specific safety and bealth plan shall provide for pre-entry briefings to be beld prior to iritiating any site activity, and at such other times as oscessary to easure that employees are apprised of the site satery and health plan and that this plat is being followed. The infortuation and data obkained from site charaterization and malysis work required in paragraph (c) of this section shall be used to prepare and update the site safety and bealth plan."

\section{FACIIITY REQUIREMENT SOURCE: 29CFR1910 Part 120(d)(1)}

"Site control.

Appropriats site control procedures shalt be impiemented to control employee exposure to hazardous substances before clean-up work begins." 


\section{REQUIREMENTS IDENTIFICATION DOCUMENT HIGH LEVEL WASTE STORAGE TANK FARMS Oecupational Safety and Health}

FACHLTY REQUIREMENT SOURCE: 29CFR1910 Part 120(d)(2)

-Site controt program. A site control program for protectiog employees which is part of the employer's site safety and bealth prostadr required in paragragh (b) of this section stall be developed darting the planning stages of a hamardous waste cenatup operation and modified as necessary as dew information becomes available."

\section{FACILITY REQUIREMENT SOURCE: 29CFR1910 Part 120(d)(3)}

"Elements of the site control program. The site control program shall, as a minimum, ineludes A sile map; site work 200ats; the use of a "buddy system;" sils communications inciuding alerting means for omergencies; the standard operating procedures or safe work practices; and, identification of the oearegt medieal assistance. Whers these requirements are covered olsowhere they need pot be repested."

\section{FACILITY REQUREMENT SOURCE: 29CFR1910 Part 120(j)(9)(i)}

"Tank and vault prosedures. Tanks and vaults contsining bazardous substarces stall be handled in a manner sizrilat to that for dnums and containers, taking into consideration the size of the tank or valt."

\section{FACILITY REQUIREMENT SOURCE: 29CFR1910 Part 120(j)(9)(ii)}

"Appropnizte ank or vault entry procedures as described in the employer's safely and heslth plen shall be followed whenever empioyees must enter a tank or vault."

\section{FACILITY REQUTREMENT SOURCE: 29CFR1910 Part 120(k)(1)}

"Decontamitration. Generat. Procedures for all phases of decontamination stall be developed and implemented in accordance with this paragrapb."

\section{FACILITY REQUIREMENT SOURCE: 29CFR1910 Part 120(k)(2)(i)}

- Decontamination procedures. A decontamination procedurs shall be developed, communicated to employees and implemented before any employees or equipment may enter areas on site where posential for exposure to hazardous substances exists."

\section{FACILITY REQUIREMENT SOURCE: 29CFR1910 Part 120(k)(2)(i)}

"Decontomination procedures. Standird operating procedres shafl be developed to minimize employee contact with hazardous substances or with equipment that has contacted hazardous substances."

\section{FACILITY REQUIREMENT SOURCE: 29CFR1910 Part 120(k)(2)(iit)}

-Decontamination procedures. All employes leaving a contaminated area shalt be appropriately decontzminated; all contaminated clothing and equipment leaving a contaminated area shall be appropriztely disposed of or decontaminated." 
WHC-EP-O750

\section{REQUIREMENTS IDENTIFICATION DOCUMENT \\ HIGH LEVEL, WASTE STORAGE TANK FARMS \\ Occupational Safety and Health}

\section{FACILITY REQUIREMENT SOURCE: 29CFR1910 Part 120(k)(2)(iv)}

"Decoatamination procedares shall be monjtored by the site safety and hesleh supervisor to determine their effectiveaess. When such procedures are found to be tmeffective, appropriate steps shall be taked to correct any defictencies."

\section{FACILITY REQUREMANT SOURCE: 29CFR1910 Part 120(k)(3)}

"Location. Decontamination shalt be performed in geographical areas that will minimize the expostre of uncontaminated employees or equipment to conbminated employees or equipment."

\section{FACILFTY REQUIREMENT SOURCE: 29CFR1910 Part 120(k)(d)}

"Decontamination procedures. Eqquipment and solvents. All equipment and solvents used for decontamieation shall be decontaminated or disposed of properly."

\section{FACILITY REQUIREMENT SOURCE: 29CFR1910 Part 147 (c)(5)(iii)}

\section{"Lockout and Tagout}

Tagout devices shall warn against bezardous conditions if the machine of equiprosat is energized and shall include a legend such as the following: Do Not Start, Do Not Opea, Do Not Closse, Do Not Energize, Do Not Operate."

\section{FACILITY REQUTREMENT SOURCE: 29CFR1910 Part 147 (c)(8)}

"Lockout and Tagout

(8) Energy isolation. Lockott or tagout shall be perfortmed only by the authorized employees who are performing the servicing or maintenante."

i

FACILITY REQUMEMENT SOURCE: 29CER1910 Part 147 (c)(9)

"Lockout and Tagout

Notification of employees. Affected enployees shall be notified by the employer or zuthorizzd employee of the application and removal of tockout devices or cagout dovices. Notification shall be given before the controls are applied, and after they are removed from the machine or equipment."

\section{FACIITY REQUREMENT SOURCE: 29CFR1910 Part I4T (d)(1)}

\section{"Lockout and Tagout}

The established procedures for the application of energy control (the lockout or tagout procedures) shall cover the following elements and actions and shall be doat in the following sequence: $\{[$ sic) $\{1),(2),(3),(4),(5),(6)\}$ (1) Preparation for shutdown. Before an authorized or affected employes hurs off a machire or equipment the authorized employe shall have knowledge of the type and magnitude of the energy, the bazards of the energy to be controlled, and the method or means to control the energy." 


\section{REQUIREMENTS IDENTIFICATION DOCUMENT HIGH LEVEL WASTE STORAGE TANK FARMS \\ Occupational Safety and Heaith}

\section{FACILITY REOUIRFMENT SOURCE: 29CFR1910 Part 147 (d)(2)}

"Lockont and Tagout

(2) Marhine or equipmeat shutdown. The machioe or equipment shall be turned oft or shut down using the procedures estabitshed for the mechine or equipment. An orderly shutdown must be utilized to avoid any additional or increased bazardi(s) to enaployees as a restlt of the equipment stoppage. "

\section{FACILITY REQUIREMENT SOURCE: 29CFR1910 Part 147 (d)(3)}

\section{"Lockout and Tagout}

(3) Machine or equipment isolation. All epergy isolating devices that are needed to control the energy to the machine or equipment shall be pbysically located and operated in such a manger as to isolate the machine or equipment from the energy sourcer(s)."

\section{FACILITY REQUIREMENT SOURCE: 29CFR1910 Part 147 (d)(4)}

-Lockout and Tagout (4)(i) Lockout or tegout devices shall bo affixed to tach tnergy isolating device by authorized employees. (ii) Lockout devices, where used, shal] be affixed in a manner to that will bold the eqercy isolating devices in a "safe" or "off" position (iii) Tagout devices, where used, stall be affixed in such 2 manner as witl cleody indicate that the operation or movement of entergy isolating devices from the "safe" or "oft" position is probibited. (A) Where tagout devices are used with eoergy isolating devices desigaed with the copability of being locked, the tag attachment shall be festened at the sime point at which the lock would bave been attached. (B) Where a tag cannot be affixed directly to the energy isolating device, the tag shall be located as close as safely possibje to the device, in a position that will be impediately obvious to anyone attempting to optrate the device."

\section{FACILITY REQUIREMENT SOURCE: 29CFRI910 Part 147 (d)(5)}

\section{"Lockout and Tagout}

(S) Stored energy. (i) Following the application of lockout or tagout devices to energy isolating devices, 2l3 potentially hazardous stored or residual energy shall be relieved, discomected, restrained, and other wise rendered safe. (ii) If there is a possibility of reaccumulation of stored energy to a bazardous level, verification of isolation shall be continusd until the servicing or mxintenance is completed, of uotil the pessibility of sucb accumulation no longer exists."

\section{FACILITY REQUIREMENT SOURCE: 29CFR1910 Part 147 (d)(6)}

"Lockout and Tagout

(6) Verifiention of isolation. Prior to starting work on machines or equipment that hava been [ocked out or tagged out, the anthorized employee shall verify that isolation and deenergization of the machine or equipment bave been accorplished."

\section{FACILITY REQUIREMENT SOURCE: 29CFR1910 Part 147 (e)(1)}

"Lockout and Tagout

(e) Release from lockout or tagout. Befort lockout or tagont devices are removed and entergy is restored to the machine or equiprneat, procedures shall be followed and actions taken by the 


\section{REQUIREMENTS IDENTIFICATION DOCUMENT HIGH LEVEL WASTE STORAGE TANK FARMS Occupational Safety and Health}

authorized employes(s) to ensure the following: (1) The machine or equipment. The work aren shall be inspected to ensure that nonessential itoms have been removed and to easure that machines or equipmeat componeots are operationelly intact."

\section{FACILITY REQUIREMENT SOURCE: 29CFR19I0 Part 147 (e)(2)}

"Lockout and Tagout

(e)(2) Employees. (1) The machinte or equipurent. The work 2res shall be checked to ensure that all onaployees bave ben safely positioned or removed. (ii) After lockout or tagout devices have been removed and before a machine equipment is started, affected employees stall be notified that the lockout or tagout device(s) bave been ramoved."

\section{FACILITY REQUIREMENT SOURCE: 29CFRI910 Part 147 (e)(3)}

"Lockout apd Tagout

(e)(3) Lockoat or tagout devices removal. Each lockout or tagout device shall be removed from each energy isolating device by the employee who applied the device. Exception to paragrapt (e)(3): When the authorized encoloyes who applied the lockout or tigout device is not available to remove it, that device is not avaitabie to remove it, that device may be renoved under the direction of the employer, provided that specific procedures and training tor such removal bave been developed, documented and incorporated into the employer's energy control program. The employer shall demonstrate that the specitic procedure provides equivalent safety to the removal of the device by the authorized employee who applied it. The specific procedure shafl include at least the following etements: (i) Verification by the employer that the suthorized employee who applied the device is not at the facility; (ii) Making all ressonable efforts to contact the authorized exsployee to inform him/her tbat his/her lockout or ragout device has been removed; and (iti) Ensuring that the authorized employee bas this knowledge before be/she resumes work at that facility."

\section{FACILITY REQUTREMENT SOURCE: 29CFR1910 Part 147(c)(1)}

-Lockout and Tagout

(c) Genterst-1 Energy Control Program. The employer shall establish a progran consisting of coergy control procedures, employe trainting and periodic inspections to ensure that before an employes performs any servicing or maintenanes on a machine or equigment where the unexpected ensrgizing. start up or release of stored energy could occur and cause injury, the machine or equipment shal] be isolated from the energy source, and rendered inoperative."

\section{FACILITY REQUIREMENT SOURCE: 29CFR1910 Part 147(c)(2)(i)}

\section{"Lockout and Tagout}

(c) Getteral-2 Lockout/tagout. (i). If an energy isolating device is not capabile of heing lockect out, the employer's energy control program under paragraph (c)(J) of this section stall utilized a togout system."

\section{FACILITY REQUIREMENT SOURCE: 29CFR1910 Part 147(c)(2)(iii)}

\section{"Lockönt and Tagout}

(c) General-2 Lockoutitagout. (iii). After January 2, 1990, whenever replacement or minjor tepair, renovation or modification of a machine or equipment is performed, and whenever tew 


\section{REQUIREMENTS IDENTIKLATION DOCUMENT HIGH LEVEL WASTE STORAGE TANK FARMS Occupational Safety and Health}

machines or equipment are installed, epergy isolatiog devices for such machine or eguipment shall be desigeed to accesp a lockout devtoe."

\section{FACILTY REQUIREMENT SOURCE; 29CFRT910 Part 147(c)(3)(3)}

\section{'Lockout and Tagout}

(c) (3) Full employee Protection. (i) When a tagout device is used on an energy isolating device which is capable of being locked out, the tagout device shall be attached at the same location that the lockout device would have been attached, and the exppioyer stall demonstrate that the cagout program will provide a kevel of safery equivalent to that obtained by using a lockout program."

\section{FACILITY REQUIREMENT SOURCE: 29CFR1910 Part I47(c)(3)(i)}

"Lockout and Tagout

(c)(3)(ii) In demonsteating that a level of safery is achieved in the ugout program which is equivalent to the level of safety obmined by using a lockont program, the employes stall demanstrate lull compliance with all tagout related provisions of this standard together with such adfitionai elements ase necessary to provide the equivalent safecy available from the use of a lockout devict. Adfitionsl meins to be considered as part of the demonstrition of thll empioyee protection shal] include the inplementation of additional sofety measures such as the removal of an isoisting circuit element, blocking of a controlling switch, opening of an extra disconnecting device, or the removal of a valve handle to reduce the likelihood of inadvertent energization."

\section{FACILITY REQUIREMENT SOURCE: 29CFR1910 Part 147(c)(4)(i)}

\section{-Lockout and Tagoat}

(c)(4) Energy control procedure. (t). Procedures stall be developed, documented and utilized for the control of poteatially bezartous energy when employees are engaged in the activities covered by this section. Notes Exception: The employer need not document the required procedure for a particuler machine or equipment, when all the following elements exist: (1) the rnachisic or equipspent has no potential for stored or restidual energy or reaccumrlation of stared entergy after shrt down which could endanger employees: (2) the michine or equipment has a single energy source which can be readily identified and isolated: (3) the jsolation and locking out of that eacrgy source will completely deenergize and deactivate the mechine or equipment; (4) the machize or equipment is isolated from that eoergy source and locked out during servicing or maintenante; (5) a single lockout devjes will wchieve a locked-out condition;(6) the lockout device is under the exclusive control of the authorized employee performing the serviciag or maintersantes: (7) the servicing or maintempen does aot create hazards for other employees; and (8) the tmployee, in utilizing this exception has not bad necidents involving the unexpected activation or reenergization of the machine or equipment duriog servicing or maintenence."

\section{FACILITY REQUIREMENT SOURCE: 29CFR1910 Part 147(c)(4)(ii)}

"Lockout and Tagout

(ii) The procedures shall clearly and specifically outline the scope, purpose, authotization, ntles, and technigtes to be utilized for the control of bazardous energy, and the means to otforce compliance including, but not limited to, the following: (A) A specific statement of the intended use of the procedure; (B) Specific procedural stops for the shutting down, isolating, 


\section{REQUIREMENTS IDENTIFICATION DOCUMENT HIGH LEVEL WASTE STORAGE TANK FARMS Occupational Safety and Healtb}

bloxking and securing machines or equipment to control hazarious energy; (C) Specific procedural steps for the placementh rempoval and transfer of locisout devices or thgout devices and the responsibility for them; and (D) Specific requirements for testing a machine or equipment to determine and verify the effectiveness of lockout devices, hagout devices, and other energy controd measuras."

\section{FACIIIY REQUIREMENT SOURCE: 29CFRI910 Part 147(c)(5)(1)}

"Lockout and Tagout

(i) Locks, tegs, chains, wedges, key blocks, adapter pins, self-locking fasteners, or other hardware stall be provided by the empioyer for isolating, securing or blocking of machines or equipment from eargy sources.

\section{FACILITY REQUIREMENT SOURCE: 29CFR1910 Part 147(f)(2)}

"Lockout and Tagout

(f) Additionel requirements (2) Outside pefsonnel (contractors, etc) (i) Whenever outside servicing personnel are to be engaged in activities covered by the scope and applieation af this standard. the on-site employer and the outside employer shall inform each other of their respective lockott or tagout procedures. (ii) The on-site employer shalt ensure that bis/ber onployes tinderstand and comply with the restrictions and probibitions of the outside employer's energy contral program."

\section{FACILITY REQUIREMENT SOURCE: 29CFR1910 Part 147(t)(3)}

"Loekont and Tagout

(f) Groutp lockout or tagout (i) When servicing and/or maintenance is performed by a crew, ceaft, department or other group, they shall utilize a procedure whisch affords the employes a tevel of protection equivalent to that provided by the implementation of a personal lockout or tagout device. (ii) Group lockout or lagout devices stall be used in accordance with procedures required by paragraph (C)(4) of this section including, but not necessarily timited to, the following specific requizements; (A) Primary responsibility is vested in an authorized employes for 2 set nurtiber of engloyess working under the protection of a group lockout or tagout device (such as operations lock): (B) Provision for the authorized employee to ascertein the exposure stratus of individual group mentbers with regard to the lockout or tagout of the mexhine or expiptient and (C) When more than abe crew, craft, department, etc. is involved. assignment of overall job-2sscocinted lockout or tagout control responstbility to an authorized employee designated to coordinate affected work forees and ensure contiruity of provection; and (D) Each authorized empioyee shall afix a personal Jockout or tagout device to the group lockout device, group lockbox, or coraparble mechanisn when be or sbe begins work, and shall remove lanose devices when he or she stops working on ths machine or expipment being serviced or maitrtained."

\section{FACULTY REQULREMENT SOURCE: 29CFR1910 Part 303 (n)}

"Electrical utilization systerns.

(f) Identification of disconnecting means and circuits. Each disconnecting means required by tuis subpart for motors and appliances shall be legibly morked to indicale its purpose, unless located and arranged so the puspose is evident. Each service, feeder, and branch circtit, at its disconuecting means or over current device, shall be legibly marked to indicate its ptrrpose, 


\section{REQUIREMENTS IDENTIFICATION DOCUMENT HIGH LEVEL WASTE STORAGE TANK FARMS Occupational Safety and Health}

unless located and arranged so the purpose is evidient. These markings shall be of sufficieot dumitility to withstand the enviromment involved."

\section{FACILITY REQUREMENT SOURCE: 29CFR1910 Part 305 (j)(4)(1)}

Wiring methods.

(4) Motors. This paragraph applies to motors, motor circuits, and controlkers. (i) In sight from. If specified that one piece of equipment shall be "in sight from " amotber pitece of equipment, one siall be visible and not une than 50 feet from the otber."

\section{FACILTY REQUIREMENT SOURCE: 29CFRI910 Part 333 (a)}

"Selextion and use of work practices

(a) Geperal. Safety-related work practices shalt be employed to provent electric shock or ober injuries resulting from either direct or indirect electrical contacts, when work is performed near or on equipment or circuits which are or may be extergized. The specific safety-related work pratictes shall be consistent with the nature and extent of the associated efectrical hazards."

\section{FACILITY REQUIREMENT SOURCE: 29CFR1910 Part 333 (a)(1)}

\section{-Selection and use of work prectices}

(a)(1) Deenergized parts. Live parts to which an employes may be exposed sball be dennergized before the employee works on or near them, unles the employer can derronstratt that desnergizing introduces additional or increased hazards or is infeasible dus to equipmentdesign of operational limitations. Live parts that operate at less than 50 volts to ground peed pot to be denergized if there wifl be ao incressed expostre dae to electrital ares. Note l: Examples of increased or additional hazards include internytion of lifo support equipment. deactivation of emergency atarm systens, shutdown of hazardous location ventilation exuipment, or removal of illumination of an area. Note 2: Examples of work that may be pertorned on or near energized circutit paris because of infensibility dus to equipenent redesigu or opsrational limitation include testing of electric circuits that can only be performed with the circuit energized and work on circuits that form an integral part of a contiruous industrial processing a chemical plant that would otberwise need to be completely shut down in order to permit wark on one circuit or piece of equipment. Note 3: Work on or near deenergized parts is covered by paragraph (b) of this section."

\section{FACILITY REQUREMENT SOURCE: 29CFR1910 Part 333 (a)(2)}

"Selection ind the of thork practices

(a)(2) Energized parts. If the exposed live parts are not deenergized (i.e., for reosons of increased or additional hazands or infeasibjlity), otber safety-related work practices shall be used to protect expipioyes who may be exposed to the electrical hazards involved. Such work practioes shall protect employees against contact with soergized circuit parts directly with any part of their body or indinectly through sone other conductive object. The work practices that are usted shal] be suituble for the contitions aoder which the work is to be performed and for the voltage leved of the exposed electric conductors of cireuit parts. Specific work practioe requitements are detailed in paragraph (c) of this section." 


\title{
REQUIREMENTS IDENTIFICATION DOCUMENT FIGH LEVEL WASTE STORAGE TANK FARMS Occupational Safety and Health
}

\author{
FACILITY REQUIREMENT SOURCE: 29CFR1910 Part 333 (b)(1)
}

-Selection ard use of work practices

(b) (1)Working on or near exposed deecergized parts. (1) Application. This paragraph applies to wark on exposed deenergized parts or uear enongl to them to expase the employee to any alectrical hazard they preseat. Contuctors and parts of electric equipment that have been deenergized but bave not been locked out or tagged in accordence with paragraph (b) of this section shall be treated as energized parts, and paragraph (c) of this section applied to wark on or near them."

\section{FACILIY REQUIREMENT SOURCE: 29CFR1910 Part 333 (b)(2)(iv)}

"Selection and use of work practice

(2)(iv) Verification of deenengized condition. The requirements of this paragraph shall be met before any circuits or equipment can be considered and worked as deenergized. (A) A qualified person shall operate the equipment operating cototrols or atherwise verify that the equipment cannot be restarted. (B) A qualified person shatt use test equipment to test the circutt element and electrical parts of equipmeat to which employees will be exposed and shall verify that the circuit elements and equipment parts are deenergized. The tast shall also determine if any energized condition exists 28 a result of indidvortently induced voltage or unrelated voltage back feed even though specific parts of the circuit bave been deenergized and presumed to be safe. If the circtit to be tested is over 600 volts, nominal, the test equipmeat shalf be checked for proper operation immediately before and imnediatedy after this test."

\section{FACILITY REQUEREMENT SOURCE: 29CFR1910 Part 333 (b)(2)(v)}

-Selection and use of work practices

(b)(2)(v) Retnergizing equipment. These requirements shall be met, in the order given, before circuits or equipment are renergized, even temporarily. (A) A qualified person shall contuct tests and vistal inspection, as pecessary, to verify that all cools, electrical jumpers, shorts. grounds, and other such devices have been removed, so that the circuits and equipment can be safely eaergized. (B) Employes exposed to the hazards associated with reenergizing the circuit or equipment shalt be warped to say clear of circuits and equiprrent. (C) Each lock and tag shall be removed by the employee who applied it or under his or her direct supervision. However, if this employes is absent from the workplace, then the lock or tag may be removed by a qualified person designated to perform this task. Provided that: (1) The employer easures that the employee who applied the lock or tag is not available at the workplace, and (2) the employer ensures that the employee is aware that the lock or tag has been removed befort be or she resumes work at that workplace. (D) There stall be a visual determination that all employees are clear of the cireuits and equipment."

\section{FACILITY REQUIREMENT SOURCE: 29CFR1910 Part 333 (c)(1)}

Selection and use of work practices

(c) Working on or near exposed energized parts. (1) Appolication. This paragraph applites to work performed on exposed live parts (involving either direct contact or contact by means of tools or materials) or near enoutgit to thern for employees to be exposed to any hazard they present. 
WHC-EP-OTSO

\section{REQUIREMENTS IDENTIFICATION DOCUMENT HIGH LEVEL WASTE STORAGE TANK FARMS Occupational Safety and Fealth}

\section{FACILITY REQUIREMENT SOURCE: 29CFR1910 Part 333 (c)(2)}

"Selection and use of work practices

(c)(2) Work on energized equipment. Only quiljfied persons myy work on electric circuit parts or equipwent that bave not been detorgized under the procedures of parserph (b) of this section. Such persons shall be capable of working safely on energized circuits and shall be farriliar with the proper t; use of special precautionary tocheniques, personal protective equipment, insulating and shieldicg monterials, land instlsted tools. *

\section{FACILITY REQUIREMENT SOURCE: 29CFR1910 Part 333 (c)(3)}

"Selection and use of work praxtices

(c)(3) Overhead lines. If work is to be perfonned near overbead lines, the lines shall be deenergized and grounded, or other protective measures shall be provided before work is started. If the lines are to be deenergized, arrangements shall be made with the person or organization that operates or controls the electric circuits involved to deenergize and ground thert. If protective jpeasures, such as guarding, isolatiog, or insulating are provided, these precautions sball prevent employes from contacting such lines directly with any part of their body or indirectily through conductive materials, tools, or equipment. Note: The work practices used by qualified persons installing insulating devices on overtead power transmission or distribution lines are not covered by 1910.332 through 1910.335. Under paragraph (c)(2) of this section, unqualified persons are prohibited from performing this type of work."

\section{FACIEITY REQUIREMENT SOURCE: 29CFR1910 Part 333 (c)(3)(i)}

\section{- Selection and use of work practices}

(j) Unqualified persons. (A) whon an unqualified person ts working in an elevated posttion near overiead lines, the location shall be such that the persoo and the longest conductive object he or she may coatact cannot corde closer to any unguanded, opergized overbead line then the following distances: (1) For voltages to ground $50 \mathrm{kV}$ or below-10ft. $305 \mathrm{~cm}$; (2) For voltages

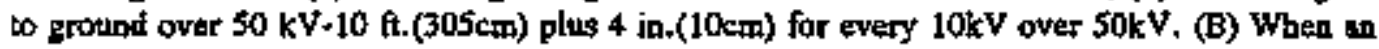
unqualified person is working on the ground in the vicinity of overtead lines, the person may not ring any conduetive object closer to unguarded, energized overhead lines thet the distrinces givea in paragraph (c)(3)(i)(A) of this section. Note: For voltages normally encountered with overbead power lines, objects which do not have an insulating rating for the voltage involved are considered to be conductive."

\section{FACILTY REQUIREMENT SOURCE: 29CFR1910 Part 333 (c)(3)(it)}

-Selection and use of work practices

(ii) Qualified persons. When a qualified person is working in the vicinity of overhead lines, whether in an elevated position or on the ground, the person may not approach or take any conductive object without an approved insulating bandle eloser to exposed eaergized parts than shown in Table S-5 anless: (A) the energized part (gloves with sleeves if necessary, rated for the voltage involved are considered to bo insulation of the person from the energized part on which work is performed), or (B) The energized part is inculated both from all other conductive objects at a different poteotial and from the person, or (C) The person is insulated from all conductive objects at a potèntial different frow that of the energized part" 


\section{REQUTREMENTS IDENTIFICATION DOCUMENT FIGH LEVEL WASTE STORAGE TANK FARMS Occupational Safety and Health}

FACILITY REQUIREMENT SOURCE: 29CFR1910 Part 333 (c)(5)

Selection and use of work practices

(J) Confined spaces or enclosed work spaces. When an employee works in a confined or enclosed space (soch as a manabole or vault) that contrins expose energized parts, the employer shall provide, and ths excployes shal] use, protective stields, protective barriers, or insolating materials as necessery to svoid interverteot cantact with these parts. Doors, hinged parolls, tod the like shall be sectred to prevent their swinging into an omployee and causing the exployes to contact exposed energized parts."

\section{FACILITY REQUIREMENT SOURCE: 29CFRi910 Part 333 (c)(0)}

"Selection and use of work practices

(6) Conductive mattrials and squipment. Canductive materials and equipment that are in contact with any part of an employee's body shall be handled in a manner that will prevent them from contacting exposed energized copdiluctors or circuit parts. If in exmployes Intust handle long dimeosional conductive objects (such as ducts and pipes) in areas witb exposed live parts, the employer shall institute work practices (sxch as the use of insulation, guarding, and material bandling teckniques) which will minimize the hazard,"

\section{FACILITY REQUTREMENT SOURCE: 29CFR1910 Part 333 (c)(7)}

"Selection and use of work practices

(7) Portable ladders. Portable ladders shall have nonconductive side rails if they are used where the exployee or the ladder could contact exposed energized parts."

\section{FACILITY REQUIREMENT SOURCE: 29CFRI910 Part 333 (c)(8)}

"Selection and use of work practices

(8) Condictive apparel. Conductive articles of jewetry and clothing (such os watch bands, brace]ets, rings, key chains, necklaces, metalized aprons, cloth with conductive thread, of metal headgear) inay not be worn if they might contact exposed energized parts. However, such articles may be worn if they are rendered noncontuctive by covering. wrapping, or other insulating means."

\section{FACULITY REQUTREMENT SOURCE: 29CFR1910 Part 333 (c)(9)}

"Selection and use of work practices

(9) Housekeping duties. Where live paris present an electrieal contict bazard, employes may not perform bousekeeping duties at such close distances to the parts that there is as possibility of contact, unless adequare safegtaris (soch as instlating equipment or barriers) are provided, Electricalfy canductive solids such as steal wool, metalized clolh, and silicon carbide, as well as conductive liquid solutions) may not be used in proximity to entergized parts unless procedures are followed which will prevent electrical contact."

\section{FACILITY REQUIREMENT SOURCE: 29CFR1910 Part 333(b)(2)(fit)}

"Selection and use of work practices

A lock and a tag shall be placed on each discongecting means used to deenergize circuits and equipment on which work is to be performed, except as provided in paragraphs (b)(2)(jii)(C) 


\section{REQUIREMENTS IDENTIFICATION DOCUMENT HIGH LEVEL WASTE STORAGE TANK FARMS Occupational Safety and Health}

and $(b)(2)(i j)$ (E) of this section. The lock shall be attached so as to prevent persons from operating the disconnticting meins unless they resart to undwe force or the use of tools. (B) Each tag stall contain a statement probibiting unaythorized operation of the disconnecting means and removal of the tag. (C) If a lock cannot be applied, or if the employer can demonstrate rate that tagging procedures will provide a level of safety equivalent to that obtained by the use of a lock, a bag miay be used without a lock. (D) A bg used without a lock, as permitted by paragraph (b)(2)(iii)(C) of this section, shall be supplemented by at least one additional safety measure that provides a level of safety equivaleat to that obtrined by the use of a lock. Exaruples of adfitional sefety measures include the removal of an isolating sircuit elements, blocking of a controlling switch, or opening of an extra disconnecting device. (E) A lock may be placed without a tag only under the following conditions: (1) Only oae circuit or ptece of equipment is deenergized, and (Z) The lockout period does not extend beyond the work shift, and (3) Employees exposed to the hazards associated with reenergizing the circuit or equipment are fariliar with this procedure."

\section{SITE REQUIREMENT SOURCE: 29CFR1910 Section 147 (f)(4)}

"Shift or personnel changes. Specific procedures shall be utilized during shift or personnel changes to ensure the continuiry of lockout or tagout protection, incituding provision far the orderly transfer of lockoot or tigont dovice pratection between offgoing and oncoming employees, to minimize exposure to bazards from the unexpected energization or startup of the machine or equipmeat, or the release of stored energy."

\section{FACILITY REQULREMENT SOURCE: 29CFR1926 Part 417(b)}

"Locking and tagging of circtits

(b) Equipment and cirewits. Equipment or eircuits that are deenergized shall bo rendered inoperative and shall have tags antached at all points where such equipment or circuits can be epergized."

\section{FACIL,TTY REQUIREMENT SOURCE: 29CFR1926 Part 417(c)}

-Locking and tagging of circuits

(c) Tress. Tags shall be placed to ideatify plainly the equipment or circuits being worked on."

\section{FACILITY REQUIREMENT SOURCE: 54FR3904 Part (c)(3)(i)}

"So that all current and pocential hazards, bowever detected, are corrected or controlled in a timely manner, establish procedtres for that purpose, using the folfowing measures; (A) Engineering techniques where feasible and appropriate; (B) Procedures for safe work which are understood and followed by all affected parties, as a restlt of training, positive reinforoement, correction of unsafe performance, and, if pecessary, enforcement througb a clearly communicated disciplinary system: (C) Provision of personal protective equipment; and (D) Administrative controls, sacb as reducing the duration of expostire."

\section{FACILITY REQUIREMENT SOURCE: ANSI-Z244.1-1982 Section 4.2}

"Identifíation of Energy Isolatirg Devices. 
WhC-ER-0750

\section{REQUIREMENTS IDENTHICATION DOCUMENT HIGH LEVEL WASTE STORAGE TANK FARMS Occupational Safety and Health}

All energy isolating devices shail be adequatedy labeled or marked to indicste their furation, unless they are loceted and arranged so their purpose is evident. The identification stall inelude the following: (1) Equipment supptied (2) Energy type and magnitude."

\section{FACILITY REQUEREMENT SOURCE: ANSI-Z244.1-1982 Section 4.4}

"Assigument of Duties and Responsibilities.

Only knowledgeable indjividuals, shall prescribe the appropriate duties and responsibilities relating to the actual details effecting the lockout/agout. Energy isolating devices shall be operated only by autborized individuals or under the direct supervision of authorized individuals."

\section{FACILITY REQUTIREMENT SOURCE: ANSI-Z244.1-1982 Section 4.5}

"Preparation of De-energization and Start-Up Sequence(s). Where system complexity requires, a writter sequeace in checklist form should bo prepared for equipment access, lockout/tagout, clearance, release, and start-up."

\section{FACILITY REQUIREMENT SOURCE: ANSI-2244.1-1982 Section 5.1.4}

"Pre-job briefing.

Where equipment/process complexity or other conditions warrant, an authorized individulit should review the lockout/ogat sequence or plan with personnel affected by the lockout/tagout."

\section{FACILITY REQUIREMENT SOURCE: ANSI-Z.244.1-1982 Section 5.2.1}

"Equipment/Process Shutdiown.

Using appropriate equipment/process shutdown procedures all operating controls shall be wrned off or rekumed to the neutral mode by suthorized individuals."

\section{FACILITY REQUIREMENT SOURCE: ANST-Z244.1-1982 Section 5.2.4}

"Verification of isoletion.

One or both of the foilowing actions stall be accomplisbed after lackout/ugout applieation to determine if the operation of the energy isolatiog devices bas in fact produced the required izolation of the equipment/process. (1) Operate the equipment/process operating controis (pusk buttons, switches, etc) to determin that the energy isc]ation has been effective. CAUTJON: Return operating controis to nestral position after each test. (2) Test the equjpmentiprocess by use of appropriate test equipment andfor visual inspection to determine that the energy isolation bas been effective."

\section{SACHITY REQUTREMENT SOURCE: ANSI-Z244.1-1982 Section 5.3.1}

"EquiproentProcess.

Before eperay is restored to the equipment/process, a vistal inspection of the work are stalt be marie by an anthorized individual to ensurz that all nobessential items bave been removed and that alf components are operationally intact." 


\section{REQUIREMENTS IDENTIFICATION DOCUMENT HIGH LEVEL, WASTE STORAGE TANK FARMS Occupational Safety and Health}

\section{FACILITY REQUIREMENT SOURCE: ANSI-2244.1-1982 Section 5.3.2}

"Personnel.

Before energy is restored to the equipment/process, a personnel count or administrative technique shall be amplayed to verify that persountl are in the clear. This check-out procedure should be supplemented with 2 visual verification that personnel are in the clear."

\section{FACILITY REQUIREMENT SOURCE: ANSI-Z244.1-1982 Section 6.2}

"Equipment Design and Performance Limitutions.

Alternative effective protective techniques shall be employed where the equipmentiprocess design probibits uss of the established lockoutitagout dovices."

\section{FACILITY REQUREMENT SOURCE: ANSI-Z244.1-1982 Section 6.3}

"Exposure of Outside Personel.

Established lockont/tagont procedures sboutd be empiloyed for the protection of indivichals from putside organizations (service representatives, contractor's employees, and other outside personnel), where exposise exists due to their involvement with work in progress. An authorized representative of such outside orgunizations shall be made awere of estrblished lockout/tagout procedures and iaformed of the pecessity of adapting and enforcing lockout/agout protection which shalt be compatible with existing in plint lockout/lagont procedures."

\section{FACILTY REQUIREMENT \$OURCE: ANSI-Z244.1-1982 Sextion 6.4}

"Multiple Personnel Protection (Group Lockout/Tagout).

When 2 crew, craft, department, or other group lockout/tagout davioe(s) is used, tit sholl afford the affected employe a level of protection equivaleat to that provided by personal lockout/tagout devices."

\section{FACILTY REQUIREMENT SOURCE: ANSI-Z244,1-1982 \$ection 6.6}

-Authorization for Lockout/Tagout Application and Regroval.

Where written lockout/tagout plens exist and are used for complex systoms, lockout/tagout devices sinall be instelled and removed only at the direction of the authorized indivicual who has contrel of the ptin."

\section{FACUITY REQUIREMENT SOURCE: ANSI-2244.1-1982 Section 6.7}

"Work on Energized Equiputent.

Personnet performing the activities listed in 3.t, other than normal operating activitios, should do so vrader de-energized conditions in scopdence wit h the lockout/tagout procedures recained in this standard (see 5.2.1). Where work on tnergized equipment is required, acteptrable procedures and equipment shall be employed to provide offective protection to persormel."

\section{FACILITY REQUIREMENT SOURCE: ANSI-Z244.1-1982 Section 6.8}

"Production Operations. 


\section{REQUIREMENTS IDENTIFICATION DOCUMENT HIGH LEVEL WASTE STORAGE TANK FARMS Occupational Safety and Healkh}

Personnel performing the activities listed in 3.L, ather than normal operating activitites, shovid do so under de-energized cooditious in accordance with the lockout/thgout procedirts required in this strotiard (5.2.1). In the case of required repetitive minar adjustments where this is not fessible, or in the cesse of gormal production operations, these detivities shall be acoomplisbed under the protection of specially designed control circuits, control equipment, and operating procedures, that provide proven effective protection for the affected personnoli."

\section{FACILITY REOUIREMENT SOURCE: DOE-STD-1030-92 Section 4.2.1, Para. 3}

Good practices.

Under and individual-controlled lockout/togout, the individual worker is responsible for taking all necessary actions to ensure personal safery and the safety of atbers during the maintenance. To aid the worker, OSHA and DOE Order 3480.19 require the following:-Locks will be used whenever possible to secture energy or hazardous material jsolating devices. New equipment and major equipment modifications will be designed to permit the use of locks. Tags should be used to identify the person who placed the lock and the purpose of the lock. If locks eanot be used, danger tags are required. -Management should jdentify activities that requiro lockout/tagout. For each activity requifing lockout/agout, criteria should be provided to identify the locations for locks and tags. Ondy althorized personeal sobuld bave access to keys for key locks that are installed on control devices. If the operntor locks out the energy sourat by removing the ley from the control switch, it is essential to easure that no additional keys are available to unauthorized personnel. Additionglly, the control switch should be tagged. * Every isoljation from an energy or hazardous material source must be verified. Specific techriques for verification should be established by foilty procedures. The verification should inciude a review of pertinent controlled drawings or manials, and a bands-on pbysical check of the equipment. The drawings should be used to help identify the sometimes obscure sources of power or pressure (e.g. control power, indication or interlock sireuits, sensing tínes) that may be present in equipment even thougb the main (and obvious) sources bave been isolated. If a physical check is mot possible besause of hazards in the area or an existing lockats/tagout, other verification, such as observation of a rejiable position indicator, is required. Pariodic checks should be performed to ensure that componeots ane in the proper position and that locking devices are property attached."

\section{FACIIIY REQUTEMENT SOURCE: DOE-STD-1030-92 Section 4.2.3.1 Para. I}

"Geosial Practices.

A lockout /agout nust isolate all sounces of energy or bazardous materiais thet may cause personnel injury or equipment damage. For exsmple, isolating a purpp motor for bearing maintenaree shoutd also include shutting and tagging the pump stetion and discharge valves to prevent possible rotation from tluid flow."

\section{FACILITY REQULREMENT SOURCE: DOE-STD-1030-92 Seetion 4.2.3.1 Para. 2}

"Geperal Prectices.

Ondy controtled drawings, controlled system schematics, or otber controlled documents should be used as references for determining or verifying isolation points. In the abseace of controlled drawings, a physical walkdown should be performed by 2 qualified person to verify that isolatioo has been schieved." 


\section{REQUIREMENTS IDENTIFICATION DOCUMENT HIGH LEVEL WASTE STORAGE TANK FARMS Occupational Safety and Health}

EACHITY REQUTREMENT SOURCE: DOESTD-1030-92 Section 4.23.1 Para. 4

-Geveral Practices.

Some control devices "seal in" when achuated and could ceuse equipment to start when power is restored. Becouse of this component trait, the prectice of verifying lockout/tagnout isolation by operating the controls (e.g., pressing the start turtion) for the affected equipmeat should not be permitted."

FACILITY REQUIREMENT SOURCE: DOE-STD-1030-92 Section 4.2.3.1 Para. 5

"General Practices

Conlrol switches should be tagged in 2 position contaspooding to the desired protective state of tbe equipnent (0.g., OFF, neutral, pul]-to.lock), oven when another device (e.g., circuit breaker, disconnect switch, valve in poeumatic suppily line) provides the primary isointion from the energy source."

\section{FACILITY REQUREMENT SOURCE: DOE-STD-1030-92 Section 4.2,3.2}

"Electrical Practices

If electrical grounding devices are xequired, the losetion and sequence for installation of each device should be specified in the lockout/lagolt procedure. Al] electrical grounding devices used in a lockoutitagout mast be danger tagged to easure that the grounds remain in place until the work is complete, and that they are temoved before reenergizing the system."

FACILIYY REQUTEMENT SOURCE: DOE-STD-1030-92 Section 4.2.3.3 Para. 1

\section{"Piping Systems Practices}

Systems, portions of systems, and components that operate at temperatures or pressures above ambient should be vented and, if necessary for the performance of work, drained or cooled before the lockout/tagout is issued. Whenever possible, an atmosptueric drin and/or vent between the component to be worked and soures of pressurt to tite component stould be nagged in the open position to depressurize the equipment and to scocommodate thermel expansion or contraction."

\section{FACITITY REQUIREMENT SOURCE: DOE-STD-1030-92 Section 4.2.3.3 Para. 2}

"Piping Systems Practices

Systems tbat operate at high temperatures (e-g., greater than 200 degrees $F$ for 2 water system) or high pressures (e.g., greater than 500 psig), should be isolated from the work area by two closed valves in series, and a teiltale vent or drain valve between the isolation valves stould be opened. Systems contzining bazarious materials sbould be isolated by two valves in series and the isoiated section should be purged. When any of these conditions exists and two-valve jsolation cannot be provided, specifie management approval strould be obtained before performing work. Exceptions to the two-valvo isolation should be documented in the lockout'tagout resord and in the work package."

FACLITY REQUREMENT SOURCE: DOESTD-1030-92 Section 4.2.3.3 Para. 3

"Piping Systens Prectices 


\section{REQUIREMENTS IDENTIFICATTON DOCUMENT HIGH LEVEL WASTE STORAGE TANK FARMS Occupational Safety and Heaith}

Verifying depressurization by breaking tlanged connections, loosening valve bonnets, removing instrument tubing, ar other similer ections should be avoided unless no other means for verifying depressurization exists. Strict supervisory control and advance planning are required if these methods are used."

\section{FACIITY REQUmRGMNT SOURCE: DOESTD-1030-92 Section 4.2.3.4 Para. 1}

"Vajve Practices

Pneumatically operaced valves and solenoid-operated valves may be used as isolation points if the following conditions are met: - A pneumatically or solenoid-operated valve that fails open is NOT considered closed for lockout/agoul purposes, unless its power (air stpply is isolated and the valve is forcibly closed with an installed jacking device or pag. The valvo 2nd jts powwer (air) sugply isolation points must be tagged. - A paeuroztically or sotenoid-operated valve that fails closed is NOT considered closed for lockoutitagout purpases unless its power (air) supply is isolated and the valve is visuslly confirmed to be closed. The valve and its power (air) supply isolation points must be tagged."

\section{FACILITY REQUIREMIENT SOURCE: DOE-STD-1030-92 Section 4.2.3.4 Para. 2}

- Valve Practices

A pressure operated valve or cbeck valve CANNOT be used as an isolation boundary valve unless it is physically restrained in the required position by a gagging device approved by the facility."

\section{FACIIITY REQULREMENT SOURCE: DOE-STD-1030-92 Section 4.2.3.4 Para. 3}

\section{-Valve Practices}

A motor operaced valve may be used as an isolacion boundary poinc provided that, after the valve has been positioned as required by the lockoutitagout, its power supply is isolated and tagged."

FACILITY REQUIREMENT SOURCE: DOE-STD-1030-92 Section 4.2.3.4 Para. 4

\section{"Valve Practices}

The local control point (e.g., handwhesl, manusa operator) for a motor or pnesmalically operated valve must be locked/tagged when the valve is used as an isolation boundary point. Any remote control points (e.g.+ control switches, resch rods) should also be tagged, "

\section{FACILITY REQUIREMENT SOURCE: DOESTD-1030-92 Section 4.2.3.5 Para. I}

"Practices for Injecting Energy Potentials Into Systems and Components. Lockouts/tagouts that are eswblished to isolate a conponent, portion of a piping system, or electrical circuit for the pupose of injecting an energy potential for testing (e.g., hydrostatic lest, local leak-rate-fest, electrical insulation test, etc.) within the lockout/tagout boundiary required special consideration."

FACUITY REQUMREMENT SOURCE: DOE-STD-1030-92 Section 4.2.3.5 Para. 2

"Practices for Injecting Energy Potentisls Into Systems and Components. 


\section{REQUIREMENTS IDENTIFICATION DOCUMENT HIGH LEVEL WASTE STORAGE TANK FARMS Occupational Safety and Health}

The lockout/agout sbould be prepared in accordance with an approved written procedure that specifically addresses the conduct of the test."

FACIITY REQUIREMENF SOURCE: DOE-STD-1030-92 Section 4.2.3.5 Para. 3

"Practices for Injecting Energy Potantials Into Systams and Components.

The tuitial loskoub/tegant boundiries should be establisbed to protect test personol and test equipment while lest equipment is being conected to the system or component. Other work within the area isolated for testing sepuld be suspended, and all lockoussitogouts within the test boundaries should be released while testing is in progress."

\section{FACILITY REQUIREMENT SOURCE: DOEJEH0135 IH.2.5}

"5. Work penrits identify poteatially bezardouss maintenance, construction, experiments, and other non-routine ectivities sod sssure the appropitiate application of safoty and health expertise to planning and review of the work."

\section{FACI,ITY REQUIREMENT SOURCE: DOE/EH0135 WS.1.1}

*"1. There is \& systematic program for identifying, and evaluating bealth end safely concerms, which ineludes:

- Potential bealth and sefety concerns bave beeo identified, and are ovalusted to assirs that they are adequately controlled and that sundards are mot;

- Guidetines are developed for potential bealth and safely concerns if no standard or assigned permissible exposure limit exists;

- Air sampling, bioassay, noise survey, etc., are conducted at the facitity as called for by the focility policy statements; and

- Written evaluations giving the conclusions regarding the adequacy of workplace safity controls, ventilation systems, and workplace uronitoring data are seat to first level supervisors."

\section{FACILTY REQULREMENT SOURCE: DOEJEHO135 WS.1.2}

"*2. Process, operating, mechanical, and/or administrative controls are effective in assoring that the health and safety of employes are atequately controlled:

- Control measunas that are implemented are capable of achieving compliance with the applicatle standerds and DOE Orders, and

- The hierarchy of controls is as follows; engineering controls; process change or material substintion, where feasible; administrative controls; and finally, personnel protective equipment." 
WHC-EP.0750

\section{REQUIREMENTS MENTIFICATION DOCUMENT HIGF LEVEL WASTE STORAGE TANK FARMS Occupational Safety and Health}

\section{FACILITY REQUIREMENT SOURCE: DOE/EH0135 WS.4.1}

-*1. There are appropriats dengt, warning, end safety information signs throughout the facility in accordance with 29 CFR 1910, Subpart J."

FACILITY REQUIREMENT SOURCE: DOE/EH0L35 WS.4.10

"I0. Personnel are aware of and follow procedares for lockout and tagout to prevent accidental contact with energized electrical circuits and other hazardous energy soutes, in acooriance with 29 CFR 1910.147."

\section{FACILITY REQUIREMENT SOURCE: DOEJEHOL35 WS.4.8}

"*8. Elextrical safety procedures and rules are in place in accondance with 29 CFR 1910, Subpart S."

\section{FACILTY REQUIREMENT SOURCE: DOE/EH0135 WS.5.7}

“m. Electrical ssfity procedures and rutes are in place in accordance with 29 CFR 1926 , Subpart K."

\section{FACILIY REQUIREMENT SOURCE: DOE\$480.10 Section 9.a(I)}

The Operating Organization baving line safaty and health responsibilities should be required to: (a) conduct operations consistent with established bealith and safery procedures;"

\section{FACILITY REQUTREMENT SOURCE: DOE5480.10 Section 9.c(4)(b)}

"Regulated areas shall be established where chemical carcinogens are used. The cbaracteristics of regolated areas shall be appropriate to assure that access is controlled and will depend on the quanticy and pbysical properties of the material being used and on the operations beicg performed. A recont shall bo maintained of all personnel working in regulated areas."

\section{FACIIIT REQUEREMENT SOURCE: DOE5480.10 Section 9.c(4)(d)}

"Signs warning of the presence of chemical carcinogens shall be posted at al] entrances to regulated work areas. Labeits should be used on all carcinogen contairers to identify the chemical and to warn of the carcinogenic bezard."

FACILITY REQUREMENT SOURCE: DOE5480.19 Chapter IX, Section C. 2,d.(5)

"Lockout and Tagout implementation 2.d. (5) Wher locked components must be unlocked or placed in a position other then the cormal locked position, the deviation should be anthorized and dactmented." 


\section{REQUIREMENTS IDENTIFICATION DOCUMENT HIGH LEVEL WASTE STORAGE TANK FARMS \\ Occupational Safety and Health}

FACILITY REQURREMENT SOURCE: DOE\$480.19 Chapter IX, Section C. 2.d.(6)

-Lockout and Tagont Implementation, 2.d. (6) Periodic cthecks of locked components should be performed to ensure that locking devices are properly attuched and that the componeats is in the required postion."

\section{FACILITY RGQUIREMENT SOURCE: DOE5480.19 Chapter IX, Section C.2.d}

2.d. The following adouinistrative guidance is an exemple that could be established to outline acceptabie controls over lociced components: (1) A list of components that are requited to be locked strould be establiched and approved by the ogerations supervisor or appropriate manager. The list should be separate from the standard afignment cbecklists."

\section{SITE REQUIREMENT SOURCE: DOES4\$0.19 Chapter $\mathrm{X}$, Section C.2.d(1)}

"The following aderinistrative guidance is an example that coltd be establisbed to outline acoeptablo controls over locked components:

(1) A list of components that are required to be locked should be established and approved by the operations sapervisor or appropriate manager. The list should be separate from the standard alignment checklists."

FACILITY REQUREMENT SOURCE: DOE5480.19 Chapter IX, Section C.2.d.(2)

-2.d. (2) Criteria for locking of additional components and gecessary authorizations should be provided.*

FACILITY REQUIREMENT SOURCE: DOES480.19 Chapter LX, Section C.2.d.(3)

"2.d. (3) When key operated locks are used, access to the keys should be restricted to athorized personned. Keys should be readily available to appropriate personnel."

FACIEITY REQUTREMENT SOURCE: DOE5480,19 Chapter IX, Section C.2.d.(4)

2.d. (4) Specific techniques for verifying the position of kocked components should be estabtished. A hands-on physical check of critical equipment of the observation of a reliable position indicater should be used whenever possibte."

\section{SITE REQUIREMENT SOURCE: DOES480.19 Chapter 1X, Section C.4}

-Lockout/Tagout Program

A Lockaut/Tagout program sabuld be stablished consisting of procedures to control potentially hazardous energy and matertals and personnel traintog. This program should ensure that potentially hazardous anergy or toxic material sources are isolated end rendered irbperative during servicing or maintenance or in any case where unexpected energizing. startup, or nolease of stored energy or toxic material can calse injury."

STTE REQUIREMENT SOURCE: DOE5480.19 Chapter IX, Section C.S

"Procedures for kockoutrTigout 


\section{REQUIREMENTS IDENTIFICATION DOCUMENT HIGH LEVEL WASTE STORAGE TANK FARMS Occupational Safety and Fealth}

Proceduces should be developed, documented, validated, and utilized for control of potentially bazardous energy or material. Procedures should clearly and spexifically state the scope, purpose, authorization, roles, and tectniques of the LockoutTagout propram.

2. Procedures should include, but ont be limited to, the following:

(1) Specific statement of intert of use;

(2) Specific proceduril steps for isolating, blocking and securiog machine or equipment for havatdous energy or materital;

(3) Specific procedural steps for the placement, removal, and transfer of the Lockout/Tagont device(s); and

(4) Specific tequirements to test machines and to determine and verify the effectiveness of Lockout, Tagout or other control mengures.

b. It is not necessary to document the required procedure for a particular machine or equipstent, when all of the following elements txist.

(1) The machioe at equipment bas oo potential for stored or residual energy or reaccumulation of stored energy after shttdown which could endanger personnel.

(2) The machine or equipment has a single energy source which can be readily identified and isolated.

(3) The isolation and locking out of that energy source will completely de-energize and de-sctivite the mactine or equipment.

(4) The machine or equiprent is isoiated from that energy souree and locked out churing servicing or msintentance.

(5) A single lockout device will achieve a locked out condition.

(6) The lockout device is under the exclusive control of the authorized personnel performing servicing of maintenance.

(7) The servicing or maintenance dos not create hazards to other personuel.

(B) The employer, in utilizing the exception, has bad no accidents involving the waexpected activation or reenergization of the rhachine or equipment during servicing or maintenance.

c. Docementation of Lockout/Thgout

Lockout/Tagout placement, activation and removal should be rocorded inclucing any information relevant to their ocerurrence. This record should be maintaioud by the shift supervisor or appropriate manager to ensure accuracy and completenoss. The Lockout Tagout record showld be reviewed periodically by operations and maintenance personnel as guidanco.

\section{FACILITY REQUIREMENT SOURCE: DOE5480.19 Chapter 1X, Section C. $5 .(1)(2)(3)(4)$}

"Procedures for Lockout and Tagout. S. Procedures should be developed, documented, validated, and utilized for control of pocentially bazardous energy or malerial. Procedures should citerily and specifically state the scope, purpose, authorization, rules, and technichues of the Lackout/agout program. a. Procedures should include, but not be lintited to, the following: (I) Specific staternent of inteot of use; (2) Specific procedural steps for isolating, blocking and steuring mathines or equipnont for hazardous energy or materials; (3) Specific procedural steps for the placemeat, removal, and transfer of the Lockout/Tagout device(s); and (4) Specific requirements to test machizes and to determine snd verify the effectivedess of Lockout, Tagout or other control measures."

\section{STTE REQUTREMENT SOURCE: DOE5480.19 Chapter IX, Section C.6}

-Application of Lockout/Tagout 


\section{REQUIREMENTS IDENTIFICATION DOCUMENT HIGH LEVEL WASTE STORAGE TANK FARMS Occupational Safety and Fealth}

The established proceduze for the applicztion of entergy control (implementing LockoutTagout) should cover the elements and actions in the following sequence:

a. Preparation for Shutdows

Befort a mathine is turned off, persomel should be informed of the type and magnitude of the energy, the hazards and the methods of control.

b. Machine or Equipment Shutdowa

The equipment stould be shutdown using the procedures rexuired by this chapter. An onderly shutdown should be utilizad to avoid any added hazard.

c. Equipment Isolation

All Lockout/Tagout devices aeded for conirol are physically located and operated in such a mannas as to isolate the equipuent from the energy source.

d. Afinxing Locks/Tags

Lockout or Tagout devices should be affixed to exch isolation device by qualified personnel in a manner that will bold the devices in a "safe" or "off" position or chearly indicate that aperition of the devics is prohibited.

- Stored Energy

Upon application of Lockout or Tagout devices, all potentially hazardous stored or residual energy strould be relioved, disconnected, restrained, or otherwise reodered saft. If storsd energy might re-aceumulate to a bazandous tevel, verification of isolation should be continued watil the servicing or maintenance is completed.

f. Verification of Installation

Prior to starting work on equipment that has been locked or mgged out, personnel showld verify that isolation and decoergization have been acoomplisbed.

g. Release from Lockout/Tagout

Before L_ockout or Tizgout dovices are removed ad energy restored to the equipment, procedures stiould be followed and actions takea by persoanel to ensure the following:

(1) Equipment/workspace. The rachine of equipment is operationally intact. The ares has beec inspected to ensure that nonessential items have ben removed. The indivitual athorizing tag removal should specify the tinal component position and, when appropriate, the sequence in which components stould be positioned. In addition, the need to check the positioning of other components that ere not locked, or tagged, but are related to the operation of the Lockont $\pi$ agout component, should be determined at this time and appropriate instrutctions should be developed. These checks should be dooe when necessary, to encure that components within the Locked/Tagout boundaries are correctly aligned to support operation.

(2) Personnel. The workspace should be checked to ensure that al persomel bavo been positioned safely of remaved from the area. Before Lockont/Taqout devices are removed and equipment energized, aftected personnel should be notified that equipmeat will be energized.

(3) Lockout/Tagout Device Retroval. Each Lockout/Tigout device should be removed from each exiergy-isolating device by the person who applied the device. He/ste sbould reposition the components in the sequence specified and check the postioning as decmed necessary. Tot removal of Locks or Tags stiould be documented. Tags should be retumed to the operations supervisor or aurborizing manager. The supervisor/manager should be satisfied that all ogs and safety devices assocjated with this Lockout/Tagout are removed and are accountable. When the person who applied be Lackout/Tagout device is aot availsb]e to remove it, that device may be removed under the direction of the appropriate supervisod/manager, provided that specific procedures anxi training for such removal have been developed and incorporated into the facility program. The supervisor should demonstrate that the specific procedurs provides equivaleat satety to the removal of the device by the anthorized persormed who applied it. The specific procedure should include the following elements:

Verification by the surpervisorimanager that the person who applied the devico is not available. 


\section{REQUIREMENTS IDENTIFICATION DOCUMENT HIGH LEVEL WASTE STORAGE TANK FARMS Occupational Safety and Fealth}

Assurance that all reasomabile offorts are mado to inform bim/ber that the device has been removed.

Ensoring that all retevant personnel bave this knowledge before he/she reoumes work at the factility.

\section{FACILITY REQUIREMENT SOURCE: DOE5480.19 Chapter LX, Section C.9.a.}

"Caution Tazs. C.9. Caution togs should not be used for personnel protection (i.e, caution tags should not be used where it is approprizts to use a Lockont or Tagout devisel). Adrinisistration of caution rags coutd however, be accorplisbed is part of the Lockout Tagout progrand or it could be covered stparately. The use of czution tags should be restricted to those situstion in which a component of system is functional, but when some pressution or item(s) of inforaration is necessary prior to operation. In eddition, the program should include the following elements: a. Caution tags should be uniquely identifisble and difierent in appearance from other station tags. The following information should be included on the tags as an aid in administering the program: (1) caution tag number (2) componeat aamo and number; (3) efiective date; (4) presaution or information applicable to the particular situation andior component or system; and (5) sizuature of authorizing individual and organization."

\section{FACIIITY REQUIREMENT SOURCE: DOES480.19 Chapter IX, Section C.9.b.}

"Custion Tags. C.9. b. Situations that require special operator or maintenance preceations or amplifying information should be brought to the attention of the shift supervisor or appropriate manager. The supervisor or manager should ensure that issuing a caution tag is necessenty and that the tog is tot being used in place of more appropriate administrative attion (such as a temporary procedure change, placing an operator aide, use of the work control system, or issuance of a safety Lockout or Tapout). The supervisor review should also ensure that any instruction contained in the caution tag does not deviate from established facility procedures, tectinical specifications, or OSR's."

\section{FACIEITY REQUIREMENT SOURCE: DOE5480.19 Chapter IX, Section C.9.C.}

"Caution Tags. C.9. c. Caution tags. A record of all active caution tags and associated amplifying informotion should be aveilable to the appropriate personnel. This record and sssociated tags shall be reviewed periodically by qualified personnel. This review should verify the continued noed and applicability for each caution ag and onsure that the caution tog index accurstely refiects all active caution tags. This reviow should be doctunented. Any caution thos remaining in an active status for extended periods (6.g., longer than three mooths, as appropriate) should be brought to the atteption of the operations supervisor or manager. The operations strpervisor or manger should determinte what action is aeeded to resolve the continued use of the cation tag. "

\section{FACILIY REQUIREMENT SOURCE: DOE5483.1A Chapter I, Section 1 \& 2}

"1. DOE-PRESCRIBED OSHA STANDARDS. As applicoble to their work is GOCO facilities, contrextors shatl cormply with the following DOE-prescribed OSHA stondirds: a. "Oceppational Safecy and Health Stapdaris," Title 29 CFR Part 1910.

b. "Safoty and Healtb Regulations for Construction," Title 29 CFR Part 1926. c. "Oceupational Safety and Healtb Standards for shipyard Employees," Title 20 CFR Part $10 \mathrm{t5}$. 


\section{REQUIREMENTS IDENTIFICATION DOCUMENT HIGF LEVEL WASTE STORAGE TANK FARMS Occupational Safety and Health}

d. "Safety and Health Regulation for Longshoring," Title 29 CFR Part 1918.

c. "Oceupational Sefety and Health Standards for Agricultare," Titls 20 CFR Part 1920.

2. STANDARDS FILE. Each contractor shall assure that current copies of DOE-prescribed OSHA standards cited in paragrept 1, above, along with the contractor's own seftaty and health

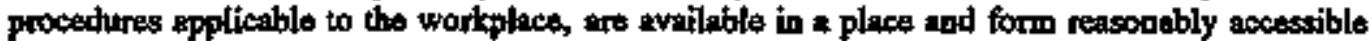
to all expioyes and their authorized representatives."

\section{FACILITY REQUIREMENT \$OURCE: DOES483.1A Chapter I, Section 5.a.(1)}

"All contractor employes stall be instructed by the contrattor to:

(1) Obsarve the DOE-prescribed OSHA standards applicable to their work and report promptly to the contractor any condition which may lead to a violation of these standards."

\section{FACILITY REQURREMENT SOURCE: WAC-296-24 Section 11009(5)}

"Lockout or tagout devices removel. Fach lockout or tagout device shatl be reuroved fiom each energy isolating device by the employee who applied the device. Exeeption: When the antborized employe who applied the lockout or tegout device is not available to remove it. that deviou miy be removed under the difection of the employer, provided that specific procedures and training for such removal have beeo developed, documented, and incorporated into the elpployer's tnergy controt program. The employer shait demonstrate that the specific procedure provides equivaleat safery to the removal of the device by the authorized employes who applied it. The specific procedure shall include at least the following elements:

(a) Verification by the enployer that the anthorized exployee who applied the device is not at the facility;

(b) Making all reasonable efforts to contact the authorized omplayes to inform him/ber that hisher lockout or cagout dovice has been removed; and

(c) Ensuring that the authorized employee has this knowledge before be/she resumes work at that fiecility."

\section{FACILITY REQUIREMENT SOURCE: WAC-296-24 Section 11011(1)}

"Testing or positioning of markines, equipmeat, or components thereof. In situations in which lockout or tagout devices must be temporarily removed from the energy isolating device and the machine or equiprent energized to test or position the machatin, equipment or component thereofi, the following sequence of actions shall be followed:

(a) Clear the machine or equipment of tools and materials in accordance with WAC

296-24-i 1009;

(b) Remove erployes from the machine or equipment area in accordance with WAC

296-24-11009;

(c) Rembve the lockout or tagout devices as specified in WAC 296-24-11009;

(d) Enorgize and proceed with testing or positioning;

(c) Deenergize all systems and reapply onergy control measures in accordance with WAC

296-24-i1007 to contiuue the servicing and/or maintentence."

\section{FACILTY REQUIREMENT SOURCE: WAC-296-24 Sextion 11011(2)}

"Outside personnel (contractors, ttc.).

(a) Whenever outside servieing personnel are to be engaged in ativities covered by the scope and application of this standard, the on-site employer and the outside employer shall inform ench other of their respective lockout or tagoit procedures. 


\section{REQUIREMENTS IDENTIFICATION DOCUMENT HIGH LEVEL WASTE STORAGE TANK FARMS \\ Occupational Safety and Health}

(b) The outside employer shall assare that hisher employees understand and comply with the restrictions and probibitions of the on-site employer's energy tontrol program."

\section{FACLITY REQUIREMENT SOURCE: WAC-296-24 Section 11011(3)}

"Group lockout or tagout,

(a) Whed servising and/or maintenance is perforwed by 2 crew, craft, departwent or otber proup, they shall utilize 2 procedure which aftords the employees a level of protection equivalent to that provided by the impleanentation of a personal bockour or tspout device.

(b) Group lockout or tagout devices shall be used in accordance with the procedures required by WAC 296-24-11005 (4) inckuding, bat not necessarily limited to, the following specific requirements:

(i) Primary responsibility is vested in an autborized employee for a set number of employees working ander the pratection of a group lockout or tagout device (such 2s an operations lock);

(ii) Provision for the authorized employes to ascertain the exposerte stotus of individusal group members with regard to the lockout or tagout of the machine or equipment; and

(iii) When more than one craw, craft department, etc., is involved, essignment of overatt job-associated lockout or tagout control responsibility to an authorized employee designated to coordinats affected work forces and ensurs continuity of protextion; and

(iv) Each authorized ampioyee stall affix a personai lockout or tagout device to the group lockout device, group lockbox, ot comparable mechanism when he or she begins work, and shall remove those devices when be or sbe stops working on the machine or equipment being serviced or maintained."

\section{FACILTY REQUREMENT SOURCE: WHC-SP-0708 Chapter 8, Section 5.3 paragraph 3}

"The following administrative elements shall be established to define acceptable controls over locked components: 1 . A list of components that are required to be locked may be established and approved ;by the operations supervisor or appropriate manager. The list sall be separats from the standard aligmment checklists. 2. Criteria for locking of additional components and necessary authorizatians should be provided. 3. When key operated locks are used, access to the keys stootild be reasily available and restricted to anthorized persmpt. 4. Spexific technigues for verifying the position of locked components shall be estoblished. A hards-on physical check of critical equipment or the observation of a rediable position indicator should be ased whenever possible, 5. Whan locked components must be nolocked or placed in a position ether than the normal locked position, the devjatioas stould be anthorized and documented. 6. Periodic checks of locked compontegts stall be performed to ensurt that locking devices are properly atteched and that the component is in the required position. 7 . Lockout or togout shall accomplished by authorized qualified personnel. B. All equipment which requires locking and tagging for the protection of personned from injury. protect equipment from demage, and preveat the relesse of bazardous material to the environment during maintenance, inspections, tests and aboormal activities shall be locked and byged in accordance with Chapter 9 Lockouts and Tagouts."

\section{FACILITY REQUIREMENT SOURCE: WHC-SP-0708 Chapter 9 Section 1.0, Paragraph 2.}

"The Lockout/Tagout program should provide for independent verification of the removal from service and the restoration to service of safery-related and other facility equipment." 


\title{
REQUIREMENTS IDENTIFICATION DOCUMENT HIGH LEVEL WASTE STORAGE TANK FARMS Occupational Safety and Fealth
}

\author{
FACILTY REQUIREMENT SOURCE: WHC-SP-0708 Chapter 9 Section 2.0, \\ Paragraph 3.
}

"An effective Lockout/Tagout program should be developed by ech fatility and should include devailed administrative procechures, training of personnel, and uniqualy identifiable ugs. The program should also exercise appropriate control over LockoutTagout praparation, appoval. placerrent, and removal; provide for adequate documentation; and be consistent with the requirements in 29 CFR 1910."

\section{FACILITY REQUIREMENT SOURCE: WHC-SP-0708 Chapter 9 Section 4.1,}

"Shift Supervisor. Shift supervisor shail assure that required lackouts land tegonts for their area or responsibility are prepared installed and controlled in striet adberence with facility procedures."

\section{FACILITY REQULREMENT SOURCE: WHC-SP-0708 Chapter 9 Section 5.1}

"Lockoot and Tagout Use. Locks and ngs stall be placed on controls for safety and or other special administrative reasons. Locks may be built into a switch or may be external locks (e.g., padiock) that are affixed or removed when necessary. Keys and combinotions for locks shail be controlled. Tags shall be placed on, or as close is possible to, the control that is tagged out."

\section{FACILITY REQUIREMENT SOURCE: WHC-\$P-0708 Chapter 9 Section 5.3, paragraph 4}

"When used as the sole means of preventing operations of an eoergy isolating device, togout devices, including their means of attachmest shall, in addition to other requerements for thesr tuse, be of non-reusable type, attachab]e by bead, self-locking, and aco releasable with a mininum unlocking strength of no less than fifty pounds and baving the general design and basic characteristics at least equivalent to a one piece, alt-eovitonmentil-tolerint nyton cable tie. Tagout device attachment means should be of a non-reusable type attachable by hand, self-Jocking, and oon reieasable. Identífiable-Tagout and lockout davices shall indicate the identify of the personnal and the organization applying the device. Warning-Tagout devices should warn against bazandous conditions if the muchine or equipment is energized and should inelude the legend DO NOT OPERATE.

\section{FACILITY REQURREMENT SOURCE: WHC-\$P-4708 Chapter 9 Section 5.5}

"Procedures for Lockout and Tagout.

Procedures should be developed, documeated, validated, and utilized for control of potentially bazardons energy or onterial. Procedures should cjearly add specifically stote the seope, purpose, athorization, rules, and techoiques of the Lockout Tagout program. Procedures should include, but aot be limiled to the following: 1. Specific statsment of intent of use. 2 . Specific procedural steps for isolation blocking and sectring machines or equipment for hezardous entergy or miterial. 3. Specific procedural steps for the placement, removal, and transfer of the Lockout/Tagout device(s). 4. Specific requirements to test machines and to deternine and verify the effectuveness of Lockout/T2gout or other controt measures." 
WHCEP-0750

\title{
REQUIREMENTS IDENTIFICATION DOCUMENT HGH LEVEL WASTE STORAGE TANK FARMS Occupational Safety and Health
}

\author{
FACILITY REOLLREMENT SOURCE: WHC-SP-0708 Chapter 9, Section 5.16, \\ para 3.c
}

"Caution Tags. A troord of all active CAUTION TAGS and associated amplifying information shall be available to the appropriate personnel. This record and associsted tags shall be reviewed monthly by authorized qualified personnel. *

\section{FACILIY REQUIREMENT SOURCE: WHC-SP-0708 Chapter 9, Section 5.10, para 3,d}

"Cuntion Tags. The record neview shall verify the continued aed and applicability for each CAUTION TAG and ensure that the CAUTION TAG index aceurately teflects al] active CAUTION TAGS. This review thall be documented. Any CAUTION TAGS remaining in an active status for extended periods (0.g., longer than three mostis, or as appropriate) stall be brought to the attention of the Shift Supervisor. The Shift Supervisor stall determine what action is needed to resolve the continued use of the CAUTION TAG."

\section{FACILITY REQUIREMENT SOURCE: WHC-SP-0708 Chapter 9, Section 5.10, para 3.e}

-Csution Tags. CAUTION TAG placement-CAUTION TAGS sball be pleced in such a way that they do not interfere with or obseure indicatoons, switches, or the control devices but are readily apparent to an individual before the operation of the tagged devict. Plactement of CAUTION TAGS shall be dociomented."

\section{FACILITY REQUREMENT SOURCE: WHC-SP-0708 Chapter 9, Section 5.11 para 2.e}

"Training and Communication. o When lockout systems are used, personnel shall be trained in the linjitations of tocks. The following are lock limitations: - Operations of the facility may be hindered (this is sigrificant when local conponent operatious are atecessary, such as remove shut dowa or remote control). - Locks and chains installed on small instrument line jsolation valves ca contribute to seismic loading and may not bave been considened during safery analysis."

\section{FACIITY REQUIREMENT SOURCE: WHC-SP-0708 Chapter 9, Section 5.11, para 1}

-Training and Communication. Training shail be providex and documented to ensurs that the purpose and function of the lockout and tagout program is understood by all personnel and that the ptrsoned bave the knowiedge and skills required for safe application, use, and removal of lockouts and tagouts."

\section{FACILITY REQUIREMENT SOURCE: WHC-SP-0708 Chapter 9, Section 52}

"Lockout and Tagout Implementation

If a device has the capability of being locked out, locks shall be used. If the isolating device cannot be locked out, the device shall be tagged out and an alternate method of locking out the isoisting device shall be implemented. New equipment desiga and major modifications to existing equipment stould be designed to provide the capabijity of being locked ant. 
WHC-EP-OTSO

\section{REQUIREMENTS IDENTIFICATION DOCUMENT HIGH LEVEL WASTE STORAGE TANK FARMS Occupational Safety and Health}

Experience bas shown that the use of miniature tags beve provea to be benefictal where circumstances wacrank. Miniature tags are tegout devices that are smaller in size than full size tigs yet serve the sinds function as full size togs. Minigture tags shall be used on control paneis oar other areas that have closely spaced control switches and indicators and/or push-button type control switches where altachment of a full sized tag may obsenre switches, indicators, controls, of identification tabels."

\section{FACILITY REQUIREMENT SOURCE: WHC-SP-0708 Chapter 9, Section 5.6}

"Lockout/tapout placement, activation, and removal sball be recorded, including any information relestant to their acesarence. This record shall be mintained by the Shift Suptrvisor to ensore acteracy and completeness. Personnel shall roview the changes to the lockout and tagoent record each shift as prit of the shift turnover process.(Chiptes 12)."

\section{FACILTY REQUIREMENT SOURCE: WHC-SP-(m08 Chapter 9, Section 5.7}

"The established procedure for the application of implementing lockout and kgout shall satisfy the etements of 5.2 and the following actions in sequence."

\section{FACILITY REQUIREMENT SOURCE: WHC-SP-0708 Chapter 9, Section 5.7.2}

"Machize or Equipment Sbutdown. The machine or equipment shall be shutdowd using approved procedures. An orderly shutdown shall be used to avoid any anded bazard."

FACILITY REQUIREMENT SOURCE: WHC-SP-0708 Chapter 9, Section 5.7.7, para 1

"Before lockout or tagout dovices are removed and entergy restored to the equipment, procedures should be followed to ensure the following: Eguipment/Workspace-The mechine or equiponent is operationally intact. The area bas been inspected to ensure that non essential items have been removed. Per the approved proceciure, if applicable, the individual authorizing tag removal has sperified the final compoaent position and, when appropriate, the sequence in which components should be positioned. In avdition, the need to cheak the positioning of other components that were not locked or tagger, but are related to the operations of the lockout and tagout componeat, should be determined at this time and appropriate instructions should be developed. When necessary check the postion of other components to ensure that coumponfats within the lockout/tagout boundaries are correctly aligued tn support operation."

BACIITY REQURREMENT SOURCE: WHC-SP-1708 Chapter 9, Section 5.7.7, paragraph 2

"The Shitt Supervisor shall be satisfied that atl has and safety devices associsted with the lockout and tagout area are accounted for after removal and destroy the tags."

\section{FACIITY REQULREMENT SOURCE: WHC-\$PA709 Chapter 9, Section 5.7.8}

"Lineup Verification. Independent verification of systems or component aligument should be performed and documented following removal of tags on safaty-related and other important systems, Chapter 10, independent Verification contains additional guideitines on this stlbject." 


\section{REOUIREMIENTS IDENTIFICATION DOCUMENT HIGH LEVEL WASTE STORAGE TANK FARMS Occupational Safety and Health}

FACILITY REQUIREMENT SOURCE: WHC-SP-0708 Chapter 9, Section 5.9

Tinspections shall be conducted monthy by authorized qualified personnel to determine adberence to procedures and to correct any deviations or inadequacies observed. Inspections shall include a review of the responsibilities of all personnel. The Shift Supervisor shall certify thet the periodic inspections have been performed, documenting the equipment and procedures involved, dates of inspection, personnel participating in the inspections, and personnel performing the inspections."

\section{Definitions of Terms}

This sub, sub-element conbins the definitions that are related to the Ocetpational Safety and Health aspects of the Tank Farms.

\section{SITE REQUTREMENT SOURCE: 29CFR1910 Section 147 (b), Paragraph 1}

-Affected employes. An employee whose job requires tim/ber to operate of use a machine or equipment on which servicing or maintenance is being performed under lockout or tagout, or whose job requires bim/ber to work in an area in which such servicing or maintenance is being performed,"

\section{STTE REQUUREMENT SOLRCE: 29CFR1910 Section 147 (b), Paragraph 10}

"Normal protuction operations. The utiliztion of $\&$ mschine or equipment to perform its intended production function."

\section{SITE REQUIREMENT SOURCE: 29CFR1910 Section 147 (b), Paragraph 11}

"Servicing and/or maintenance. Workplace activities such as construeting, installing, setting up, adjusting, inspecting, modifying, and maintaining andior servicing machines or equipment. These activities include lubrication, sleaning or unjorturing of machines or equipment and rnaking adjustarents or tool changes, where the enployee may be exposed to the unexpected energization or startup of the equipment or retuese of hazardous energy."

SITE REQUIREMENT SOURCE: 29CFR1910 Section 147 (b), Paragraph 12

"Setting up. Any work performed to preppre a macbine or equipment to perform its nompal production operation."

\section{SITE REQUIREMENT SOURCE: 29CFR1910 Section 147 (b), Paragraph 13}

Tagout. The placement of a tagout device on an energy isolating device, in accordance with an establisted procedure, to indicate that the energy isolating device and the equipment being conifolled may noc be operated until the tagont device is removed."

\section{SITE REQUIREMENT SOURCE: 29CFR1910 Section 147 (b), Paragraph 14}

-T2gout device. A prominent waming, device, such as a tag and a means of attechment, which can be sectrely fastened to an energy isolating device in accordance with an established 


\title{
REQUIREMENTS IDENTIFICATION DOCUMENT HIGH LEVEL WASTE STORAGE TANK FARMS \\ Occupational Safety and Health
}

procedure, to indicate that the energy isolating device and the equipment being controtled may not be operated tutil the gont device is removed."

\section{STTE REQUIREMENT SOURCE: 29CFR1910 Setion 147 (b), Paragraph 2}

"Authorized employee, A person who locks out or tugs out mathines or equipipaent in order to perform servieting or maintenince on that wechine of equipment An affected employee becomes an anthorized entoloye when that employee's duties include performing servicing or maintenance covered under this section."

\section{SITE REQUIREMENT SOURCE: 29CFR1910 Section 147 (b), Paragraph 3}

"Capable of being locked out. An energy isolating device is capatale of being locked out if it has a basp or other means of attuchment to which, or through which, a tock car be affixed, or it has a locking mechenism built into it. Other energy isolating devices are cispable of being locked out, if lockout can be achioved without tbo need to dismantle, rebuild, or fopleces the entergy isolating devies or permanently alter its energy control capability."

\section{SITE REQUIREMENT SOURCE: 29CFR1910 Section 147 (b), Paragraph 4}

"Energized. Connected to an eatrgy sources or containing residual or stored energy."

\section{SITE REQUTREMENT SOURCE: 29CFR1910 Secton 147 (b), Paragraph 5}

\begin{abstract}
"Energy isolating device. A mecbanical device that physically prevents the transmission or reteass of energy, incluting bet not linited to the following: A manually operated electrical circuit breaker, a disconnect switch; a manually cperated switch by which the conductors of a circuit can be disconnected from all uogrounded supply conductors, and, in addition, wo pole can be operated independently; a line valve; a block; and any similar device used to block or jsotste energy. Push battons, selector switehes and other control circuit type devices are got entergy isolating devices."
\end{abstract}

\section{STTE REQUIREMENT SOURCE: 29CFR1910 Section 147 (b), Parngraph 8}

"Lockout. The placement of a lockout device on an energy isolating device, in aceordance with an estab]'shed procedure, ensuring that the energy isolating device and the equipment being controlled cerunot be operated until the lockout device is removed."

\section{SITE REQUIREMENT SOURCE: 29CFR1910 Section 147 (b), Paragraph 9}

"Lockont device. A device that urilizes a positive means such as a lock, either key or combination type, to hold an energy isolating device in a safo postion end prevent the energizing of a machine or equipment. Included are blank flanges and bolted slip blinds."

\section{SITE REQUIREMENT SOLRCE: 29CFR1910 Section 331 (a)(1)}

"Premises wiring. Installations of electric contuctors and equipment within or on buildings or other structunes, and on other premises such as yards, camivol, parking, and other lots, and indnstrial substations; * 


\section{REQUIREMENTS IDENTIFICATION DOCUMENT HIGH LEVEL WASTE STORAGE TANK FARMS Oecupational Safety and Health}

\section{SIIE REQUIREMENT SOURCE: 29CFR1910 Section 331 (a), Paragraph 1}

"Covered work by both qualified and unqualified persons. The provisions of Section 1910.331 through 1910.335 cover electrical sefy-related wark pratices far both qualified persons (those who have training in evoiding the electrical hazards of working on or near exposed energized parts) and axqualified pasons (tbose with liate or no such training) working on, near, or with the following installations:*

SITE REQUIREMENT SOURCE: 29CFR1910 Section 399, Definition - Qualified Person

-One farmiliar with the construction and operation of the equipment and the bazards involved. Note 1: Whether an employes is considered to be 2 "qualified person" will depend upon various circumstances in the workplace. It is possible and, in fact, likely for an indjvidual to be considered "qualified" with regard to certain equipment in the wotkplace, but "ungualified" as to other equipraent. (See 1910.332(b)(3) for training requirements that specifically apply to qualified persons.)

Note 2: An employee who is undergoing on-the-job training and who, in the course of such training, has demonstrated an ability to perform duties safely at his or her level of trainiog and whin is under the direct stspervision of a quatified person is considered to be a qualified person for the performance of those duties."

\section{FACILITY REQUIREMENT SOURCE: WAC-296-24 Section 11003(1)}

"Affected employee. An employee whose job requires him/ber to operate or use a machine or equipment on which servicing or onaintenance is being performed ugder lockout or tagout, or whose job rexpires hinfher to work in an area in which such servicing or maintenence is being performexi."

\section{FACILFTY REQULREMENT SOURCE: WAC-296-24 Section 11003(10)}

"Normal production operations. The utilization of a machine or equiprent to perford its intended protuction function."

\section{FACIITY REQUIREMENT SOURCE: WAC-296-24 Section 11003(11)}

"Serviciog and/or maintenance. Workplace activities sueb as coostructing, instailing, setting up, adjusting, inspecting, modifying, end maintrining and/or servicing machios and equipanent. These activities inctude tubrication, cleaning, or unjamming of anahines or equipment and maiking adjustments or tool changes, where the etmployes may be exposed to the unexpected energization or startup of the equipureat or relese of bazandous ecergy.

\section{FACILITY REQULREMENT SOURCE: WAC-296-24 Section 11003(12)}

"Setting up. Any work perforthed to prepare a mexhine or equipment to perform its normal production operation." 


\section{REQUREMENTS IDENTIFICATION DOCUMENT HIGH LEVEL WASTE STORAGE TANK FARMS Occupational Safety and Health}

\section{FACILITY REQUIREMENT SOURCE: WAC-296-24 Section 11003(13)}

"Tazout. The plactment of a togout device, on an energy isolating device, in accordance with an established procedure, to indicate that the toeroy isolationg device add the equipment being controlked way not be operzted untit the togout device is removed."

\section{FACIIIY REQUIREMENT SOURCE: WAC-296-24 Section 11003(14)}

"Tagout device. A prominent waming device, sacb as a tag and a means of attachment, whicb can be securely fastenod to an energy isolating device in acoordince with in established procedure, to indicas that the energy isolating devico and the equipment being controlled may not be operated until the tagout device is removed."

\section{FACILITY REQUIREMENT SOURCE: WAC-296-24 Section 11003(2)}

"Authorized employee. A person who locks out or tags out machines of equipment in order to perform servicing or maintenance on that machine or equipmeat. An affected amployes becomes an sutborized employe wben that employee's duties include performing servicing or maintenence covered under this part."

\section{FACILITY REQUIREMENT SOURCE: WAC-296-24 Section 11003(3)}

"Capable of being locked out. An energy isolating device is capable of being locked out if it has a hasp or other means of attachment to which, or through which, a lock can be atfixed, or it has a locking mechanism buitt into it. Other entergy isolating devices are capable of being locked out, if lockout can be echieved without the need to dismantle, rebuild, or seplaco the energy isolating device or permanently alter its energy control copability."

\section{EACIIITY REQLIREMENT SOURCE: WAC-296-24 Section 11003(5)}

"Energy isolating device. A mechanical device that pbysicaily prevents the transmission or relense of energy, including but not limited to the following: A manually operated electrical circuit breaker, a disconnect switch; a mantally operated switch by which the condustors of a circuit can be disoonnected from all ungrounded stuphty conductors and, in aldition, no pole cant be operated indepeodently; a line valve; a block; and any similar device used to block or isolate enerigy. Push buttons, selector switches, and other control cireuit type devices are dot energy isolating devices."

\section{FACILTTY REQUIREMENT SOURCE: WAC-296-24 Section 11003(6)}

"Energy source. Any sotrce of eloctrical, mechanical, hydraulic, pneumatic, chemical, therunal ot other energy, including gravity."

\section{FACILITY REQUIREMENT SOURCE: WAC-296-24 Section 11003(8)}

"Lockout. The placement of a lockout device on an energy isolating device, in accordance with an establisbed procedure, ensuring that the eoergy isolating device and the equipment being controlled cannot be operated until the lockout device is removed." 


\title{
REQUIREMENTS IDENTIFICATION DOCUMENT HIGH LEVEL WASTE STORAGE TANK FARMS Occupational Safety and Health
}

\author{
FACILITY REQUIREMENT SOURCE: WAC-296-24 Section 11003(9)
}

"Lockout device. A device that utilizes a positive means such as a lock, eithor key or combination type, to hold an energy isolating device in the safe position and prevents the energizing of a machine or equipment. Included are biank flanges and bolted slip blinds."

Handling Drums and Containers

The 29CFR1910.120 Oecupational Safety and Healeb Administration (OSHA) bas Handling Drums and Conteiners Requirements." The requirements in this sub sub-element specifically aldress these requirements.

\section{FACILITY REQUIREMENT SOERCE: 29CFR1910 Part 120(j)(1)(i)}

"Handling drunss and containers.

General. Hazardous substances and contaminated soils, liquids, and other residues shall be handled, transported, labeled, ant disposed of in accordance with this paragraph."

\section{FACILIY REQUIREMENT SOURCE: 29CFR1910 Part 1200)(1)(ii)}

"Drums and containers used during the clean-up shall meet the appropriate DOT, OSHA, and EPA regulations for the wastes that they contain."

\section{FACILITY REQUIREMENT SOURCE: 29CFR1910 Part 120(j)(1)(ii)}

-When practical, drums and containers shall be inspected and their intogrity stoll be assured prtor to beting moved. Drums or containers that camot be inspected before being moved because of storage conditions (i.e., buried beneath the earth, stacked several tiers high in a pile, etc.) shal] be moved to an accessible location and inspected prior to further handing."

\section{FACILTYY REQUREMENT SOURCE: 29CFRI910 Part 120(j)(1)(iv)}

"Unlabelled drums and contriners stall be considered to contain hazardous substances and handled accordingly until the contents are positively identified and labeled. "

\section{FACILITY REQUIREMENT SOURCE: 29CFR1910 Part 120(j)(I)(x)}

"Drums and contsiners that cannot be moved without rupture, leakage, or spillage shail be enptied into a sound container using a device classified for the material being transferred."

\section{FACILITY REQUIREMENT SOURCE: 29CFR1910 Part 1200)(1)(v)}

"Site operations shall be organized to minimize the amourt of drum or container movement."

\section{FACILITY REQUIREMENT SOURCE: 29CFR1910 Part 120(j)(1)(vi)}

"Prior to movement of drums or contriners, all employes exposed to the transfer operation stiall be warned of the potential hazards associaled with the coatents of the drums or containars." 


\section{REQUIREMENTS IDENTIFICATION DOCUMENT HIGH LEVEL WASTE STORAGE TANK FARMS \\ Occupational Safety and Health}

\section{FACII.TY REQUIREMENT SOURCE: 29CFR1910 Part 1200)(1)(vii)}

"U. S. Department of Transportation specified salvage drums or containers and saitable quantities of proper abserbent shall be kept availabte and used in areas where spills, teaks, or riphires may ocear."

\section{FACILITY REQUIREMENT SOURCE: 29CFR1910 Part 1206)(1)(viii)}

"Where major spills may occur, a spill contsinment program, which is part of the employer's safety and health program reçuired in paragrapt (b) of this section, sholl bo implemented to contain and isolate the entire volume of the hazardous substance being transforped."

\section{FACIITY REQUIREMENT SOURCE: 29CFR1910 Part 120(1)(1)(x)}

"A ground-pepetrzing system or ocher type of detection system or device shall be used to estintate the loction and depth of buried drums or containers."

\section{FACILITY REQUIREMENT SOURCE: 29CFRI910 Part 120(j)(1)(xi)}

-Soil or covering material shall be removed with caution to prevent drum or container rupture."

\section{FACILITY REQUIREMENT SOURCE: 29CFR1910 Part 1200(j)(2)(i)}

-Where an girline respirator system is used, contnections to the source of air stipply stall bo protected from contamination and the entire system shall be protected from physical damage.

\section{FACILTY REQUIREMENT SOURCE: 29CFRI910 Part 220(j)(2)(it)}

"Employees not actually imvoived in opening drums or containers shall be kept a safe distance from the drums or containers being opened."

\section{FACILITY REQUIREMENT SOURCE: 29CFRI910 Part 120(j)(2)(iv)}

"Controls for drum or contuiner opening equipment, meoitorite equipment, and fire suppression equipment shall be locsted betind the expiosion-resistant barties."

\section{FACILITY REQUIREMENT SOURCE: 29CFR1910 Part 120(j)(2)(v)}

When there is 2 reasonable possibility of flammable atmospheres being present, material bandling equipment and hand tools sball be of the type to prevent sources of igmition."

\section{FACUITY REQUIRENENT SOURCE; 29CFR1910 Part 120(j)(2)(vi)}

"Drums and containers shall be opened in such a cuanner that excess interior pressure will be safety relieved. If pressure cannot be rejtieved from a remote location, appropriate shitelding shall be pixced between the employee and the drums or cantainers to reduce the ristic of exployee injury." 
พमC- सP- -130

\title{
REQUIREMENTS IDENTIFICATION DOCUMENT EIGH LEVEL WASTE STORAGE TANK FARMS Occupational Safety and Feaith
}

\author{
FACIIIY REQUREMENT SOURCE: 29CFR19I0 Part 1200)(2)(vit)
}

"Enplayees shall not stand upon or worts from drums or containers."

\section{FACILIY REQUMREMENT SOURCE: 29CFR1910 Part 120(0)(3)}

"Material handling equipment. Material handling equipment used to transfer drums and containers shal] be seiected, positioned and operated to minimize sourcess of igrition rejated in the equiprent from igniting vapors released frow rupeured doums or containers."

\section{FACILITY REQUIREMENT SOURCE: 29CFR1910 Part 120(1)(4)}

"Radioactive wastes, Drums and containers containing rediosctive wastes shail not be bardled until stoch time sa their hazard to employees is properly. assessed."

\section{FACILITY REQUREMENT SOURCE: 29CFR1910 Part 120(j)(5)(i)}

"All non-essential employoes shall be evacuated from the area of transter."

\section{FACILITY REQUIREMENT SOURCE: 29CFR1910 Part 120(j)(5)(ii)}

"Material bandling exuipment shall be provided with explosive containment devices or protective shields to protect equipment operators from exploding containers."

\section{FACILITY REQUIREMENT SOURCE: 29CFR1910 Part 120(j)(S)(tii)}

"An entployee alarm system capable of being perceived above surroundiog light and noise conditions shall be used to signal the commencement and completion of explasive waste bandling actjities."

\section{FACIITY REQUIREMENT SOURCE: 29CFR1910 Part 120(j)(5)(iv)}

"Continuous communtiketions (i.e., portable radios, hand signels, telephones, as appropriate) stall be maintained between the amployee-in-charge of the jmmediate bandling area and both the site satity and health supervisor and the command post until such time as the bandling operation is completex. Conunurication equipment or methods that could conse shock sensitive materials to explode shall not be used."

\section{FACUITY REQUREMENT SOURCE: 29CFR1910 Part 120(j)(9)(v)}

"Drums and containers under pressure, as evideaced by builging or swelling, shall not be moved until such time as the canse for excess pressure is determined and apporoptiate containmeat procedures have been inplemented to prodect employees from explosive relief of the dinm. *

\section{FACILITY REQUIREMLNT SOURCE: 29CFR1910 Part 120(i)(S)(vi)}

"Drums and containers containing packaged laboratory wastes shall be considered to contain shock-sensitive or explosive materials until they bave beed cbaracterized." 


\section{REQUIREMENTS IDENTIFICATION DOCUMENT HIGH LEVEL WASTE STORAGE TANK FARMS \\ Occupational Safety and Ffealth}

\section{FACHITY REQUIREMENT SOURCE: 29CFRI910 Part 120(j)(0)(i)}

"Lab packe shalt be opened only when necessary and then only by an individual knowledgeable in the inspection, classification, end segregetion of the comminers within the pack according to the havards of the wastes."

\section{FACILYY REQUIREMENT SOURCE: 29CFR1910 Part 1200)(6)(i)}

"If crystatline material is goted on any container, the contents stall be baodled as a shock-sensitive waste until the conterots are jdentified."

\section{FACILITY REQUTREMENT SOURCE: 29CFR1910 Part 1200)(7)}

"Sampling of drum and coatainer contents. Sampling of containers and drums shall be done in accordance with a sampling procedure which is part of the site safity and health plan developed for and avaitabte to employees and others at the specitic worksite."

\section{FACILITY REQULREMENT SOURCE: 29CFR1910 Part 1200)(8)(i)}

"Shipping and trensport. Drums and containers sball be identified and classified prior to packaging for shipment."

\section{FACILITY REQUUREMENT SOURCE: 29CFR1910 Part 120(j)(8)(i)}

"Drum or container staging areas sball be kept to the minimum number necessary to identify and classiffy materials safely and prepare then for cransport."

\section{FACILITY REQUREMENT SOURCE: 29CFR1910 Part 120()(8)(ii)}

"Staging areas stall be provided with adequate access adi egress routes."

\section{FACIL,ITY REQULREMENT SOURCE: 29CFR1910 Part 120(1)(8)(iv)}

"Bulking of bazardous wastes shall be permitted only after a thorough characterization of the materials bas beta completed."

17.3.4 Persanal Protective Equipment

This sub-element addresses the requirements for establishing programmatic controls that ensure proper identification, control and utilization of Personal Protective Equipment (PPE) where applicable. PPE shall be used where there is a question of enployes hazard exposure and a combination of onginesing and adminiztratjve controls are insufficient to control bazard oxposure. Although PPE is an effective method of limiting bazard exposure, engineering and administrative controls shall be applited to the maximum degree feasible prior to utilizing PPE as 2 means of minimizing bazard exposure. In some sintations a conbination of enginerering/adrinistrative controls may be necessary to effectively limit hazerd exposture. 


\section{REQUIREMENTS IDENTIFICATION DOCUMENT HIGE LEVEL WASTE STORAGE TANK FARMS Oecupational Safety and Health}

Specific meacures shall be implemented to mange the use of PPE incluting: definition of the methods for PPE selection, distribution and use; definition of PPE inventory, mainteance, and storage requirements; definition of PPE required inspections prior to, during, and after PPE use; and ovaluation of PPE effectiveness in the ideotified hazardous environesot. Personnel medical recpirements stall also be defined and satisfactorily completed prior to PPE issulance.

\section{FACIITY REQUIREMENT SOURCE: 29CFRI910 Part 120(b)(4)(i)(C)}

"The site sofecy and heslth plan, as a minimmm stall aldress the following: Persogal protective equipment to be used by enployees for each of the site tasks and operations being conducted as required by the personal protective equipment program in paragroph (g)(S) of this ection."

\section{FACEITY REQUIREMENT SOURCE: 29CFR1910 Part 120(b)(4)(ii)(H)}

-The site safety and bealth plan, as a minimum shall address the following: An emergexcy response plan mesting the requirements of paragraph (1) of this section for safe and effective responses to emergencies, includiog the necessary PPE and other equipment."

\section{FACILITY REQUIREMENT SOURCE: 29CFR1910 Part 120(c)(5)(1)}

"Personal protective equipment. Personal protective equipment (PPE) shall be provided and used during initial site entry in actordancs with the following requirements; Besed upon the results of the prelimuinary site evaluation, an ensemble of PPE shall be selected and used during initial site entry whicb wilt provide protection to a level of exposure below permitssible exposure limits and published exposure levels for known or suppected bazardous substances and hesth hazards, and which will provide protection against other known and strpected hazards identified during the preliminary site etaluntion. If there is to permissible exposure limit or ptblisted exposure level, the empioyer may use other published studies and information as 2 guide to appropriate personat protective equipment."

\section{FACLITY REQUIREMENT SOURCE: 29CFR1910 Part 120(c)(9)(i)}

-If positive-pressure self-contained breathing apparanus is not wed as part of the entry ensemble, and if respiratory protection is warrented by the potential bazaris ideotified turing the proliminary site ovaluation, an esctpe self-contained breathing appartinus of at least five minute's duration shall be carried by employes during initial site catry.

\section{FACILTY REQULREMENT SOURCE: 29CFR1910 Part 120(c)(5)(iti)}

-If the preliminary site evaluation does not produce sufficient information to identify the hazands or suspected hezards of the site, an ensemble providing protection equivalent to Level B PPE shall be provided as aninimum protection, and direct reating instrungents shall be used as appropriate for identifying LDLH conditions. (See appendix B for a description of Levet B bamards and the recomineodations for Level B protective equipment.)" 


\section{REQUIREMENTS IDENTIFICATION DOCUMENT HIGE LEVEL WASTE STORAGE TANK FARMS Occupational Safety and Health}

\section{FACILITY REQUIREMENT SOURCE: 29CFR1910 Part 120(c)(S)(iv)}

"Once the hazards of the site have been identified, the appropriate PPE shall be selected and used in accordance with paragraph (g) of this seation."

\section{FACIIITY REQULLEMENT SOURCE: 29CFR1910 Part 120(g)(3)(j)}

"Personal protective equipment setection. Personal protective equipment (PPE) shal] be selected and used which will protect employees from the bazands aod potentisl hazards they are likaty to encounter as identified during the site chaneterization and analysis."

\section{FACILITY REQUIREMENT SOURCE: 29CFR1910 Part 120(g)(3)(ti)}

"Personal grotective equipipent selection stall be based on in evaluation of the performance characteristics of the PPE relative to the requiremeats and limitations of the site, the task-specific conditions and daration, end the bazards and potential bazzrils identifixd at the site.-

\section{FACILITY REQURREMENT SOURCE: 29CFR1910 Part 120(g)(3)(iii)}

"Positive pressure self-contained breathing appirians, or positive pressure air-line respirators equipped with an escape air supply, shall be used when chemical exposure levels present will creote a substaptial possibility of immextiate deatb, immediate serious illoss or injury, or impair the ability to escepe.

\section{FACILITY REQUURGMENT SOURCE: 29CFR1910 Part 120(g)(3)(iv)}

"Totally-eocapsulating chemical procective suits (protection equivalent to Level A protection as recommended in appendix B) shall be used in conditions where skin absorption of a hazardous stbstapce moy result in a substantial possibility of immediate death, immediate secious jilness or injury, or impair the abjitity to escape."

\section{FACIITY REQUREMENT SOURCE: 29CFR1910 Punt 120(g)(3)(v)}

"The leved of protection provided by PPE setection shall be increased when additicnal toformation on site conditions indicates that increased protection is pecessary to redace employee exposures below permissible exposure limits and published exposure levels for bazandous substances and heatth hazards. (See appendix B for guidarce on selecting PPE ensembides.)*

\section{FACIITY REQUREMENT SOURCE: 29CFR1910 Part 120(g)(3)(vi)}

"Personal protective equipment shall be selected and used to meet the requirements of 29 CFR part 1910, strbpart I, and additional requirements specified in this section."

\section{FACILITY REQUIREMENT SOURCE: 29CFR1910 Part 120(g)(d)(i)}

"Totally-eneapsulating chemical protective suits. Totally-ncapsulating suits shall protect employees from the particular frazends which are identified during site charaterization and analysis." 
WHC-EPATSO

\section{REQUIREMENTS IDENTIFICATION DOCUMENT HIGH LEVEL WASTE STORAGE TANK FARMS \\ Occupational Safety and Health}

\section{FACHLIT REQUTREMENT SOURCE: 29CFR1910 Part 120(g)(4)(ii)}

"Totally-encapsulating suits shall be copable of maintaining positive air pressure. (See appendix A for a test method whith may be used to evaluate this requirement.)"

\section{FACULIY REQUIREMENT SOURCE: 29CFR1910 Part 120(g)(4)(iii)}

"Tocally-encapsulating suits stall be capable of preveoting inward test gas leakage of more than 0.5 percent. (Soe appendix $A$ for a test method whict may be used to ovaluato this requirement.)"

\section{FACIITY REQUIREMENT SOURCE～29CFR1910 Part 120(g)(9)}

"Persogal procective equipment (PPE) program. A witten persoudl protective equipment program, which is part of the employer's safery and bealeh program requited in paragraph (b) of this section or required in paragraph (p)(1) of this section and which is also a part of the site-specific safery and health pirs shall be oblisted. The PPE progral stall address the olements listed below. When elements, such as donining and doffing procedures, are provided by the minufachurer of a piese of equipment and are altached to the plan, they aoed not be rewritten into the plan as long $4 s$ they adequatety address the procedure or element.

(i) PPE selection bessed upon site hapards,

(ii) PPS use and limitations of the equipment,

(iii) Work resission duration,

(iv) PPE mointenance and storage,

(v) PPE decontanination and disposal,

(vi) PPE training and proper fitting,

(vii) PPE domning and doffing procedures,

(viii) PPE inspection procescufes prior to, during, and aftor use,

(ix) Evaluation of the effectiventess of the PPE program, and

(x) Limitations during temperature extremes, heat stress, and other appropriate meditol copsiderations."

\section{FACILITY REQUIREMENT SOURCE: 29CFRT910 Part 134(c)}

"Selection of respitators. Proper selection of respirators shatl be made tectriding to the puidance of American National Standiard Practices for Recpiratory Protection 288.2-1969."

\section{FACILITY REQUIREMENT SOURCE: 29CFR1910 Part 13\$(d)(1)}

-Air quality.

Compressed air, compressed axygen, liquid air, and liquid oxygen used for respiration shall be of higb purity. Oxygen shall meet the requirements of the United States Phamacopocia for medical or breathing oxygen. Breathing air shall moet at teast the requiremeats of the specification for Grede D breathing air as described in Compressed Ges Aseociation Commodity Specification G-7.1-1966. Compressed oxygen siall not be used in sapplied-air respirators or in open eircuit self-containsd bresthing apparanus tbat bave previousty used compressed air. Oxygen must never be used with air line respiritors." 
WHC-EP-0750

\section{REQUIREMENTS IDENTIFICATION DOCUMENT HIGH LEVEL WASTE STORAGE TANK FARMS \\ Occupational Safety and Health}

\section{FACLITY REQUIREMENT SOURCE: 29CFR1910 Part 13d(d)(2)}

"Brenthing air may be supplied to respirators from cylinders of air compressors."

\section{FACEITY REQUIREMENT SOURCE: 29CFRI910 Part 134(d)(2)(ii)}

"The counpessor for supplying air shall be equipped with necessary stefty and standby devices. A breathing air-typo compressor shall be used. Compressors thill be constructed and situated so as to avoid entry of contominated air into the system and suitable in-line air purifying sortent beds and Gilters installed to farther assore breathing air quality. A receiver of sofficient capticity to engble the respirator weartor to escape from a cantamizated atmosphere in event of coupressor failure, and alarms to indicate compressor faiturs and overheating shall be installed in the system. If an oil-tubricated compressor is used, it shall have a high-temperature or carton monoxide alarm, or both. If only a high-tempershure alarm is used, the air from the compressor stoll be frequently tested for carbon monoxide to insure that it meets the specifications it paragraph (d)(1) of this section."

\section{FACIITY REQUIREMENT SOURCE: 29CFR1910 Purt 134(d)(3)}

-Air line couplings shall be incompatibje with outlets for atber gas systems to preveot inadvertent servicing of air line respirators with conrespirable gases or oxygen."

\section{FACILIYY REQUIREMENT SOURCE: 29CFR1910 Part 134(d)(4)}

"Hreathing gas containers stall bo marked in atcontance with Amrerican National Standard Metbod of Marking Portable Compressed Gas Containers to identify the Marterial Containad, Z48.1-1954; Federal Specification BB-A-10\$41, June 21, 1968, Air, Compressed for Breathing Purposes; or Interis Fedecal Specification GG-B-00675b, April 27, 1965. Breathing Apparatus, Seff-Contained."

\section{FACILITY REQUIREMENT SOURCE: 29CFR1910 Part 134(e)(1)}

"Use of respirators.

Standand procedures shall be developed for respirator use. These should include alt information and guidance necessary for their proper selection, use, and care. Possible emergency and routine uses of respirators should be anticipaled and plarned for."

\section{FACHITY REQUIREMENT SOURCE: 29CFR1910 Part 134(e)(2)}

The correct respirator shall be specified for each job. Tae respirator type is usully specifited in the work procedures by a qualfified individual supervising the respiratory protective progran. The tidividual issuing them shall be adequately instructed to insure that the correct respirator is issued."

\section{FACILITY REQUREMENT SOURCE: 29CFR1910 Part 134(e)(3)}

"Written procedures shall be prepared covering safe use of respirators in dangerouts atmospheres that might be encountered in normal operations or in emergencjes. Persononel shall be familiar with these procectures and the avaitable respirators." 
WHCER+OTso

\title{
REQUIREMENTS IDENTIFICATION DOCUMENT HIGH LEVEL, WASTE STORAGE TANK FARMS \\ Occupational Safety and Health
}

\author{
FACILITY REQUIREMENT SOURCE: 29CFR1910 Part 134(e)(3)(B)
}

"In arees where the wearer, with frilure of the respirator, could be pversome by a toxic or oxygen-deficient atmospbere, at leart one additional man strall be present. Communicutions (virual, voice, or sigral line) stall be maintained between both or all individuais present. Planning shall be such that one individual will be unaffectod by any likely incident and bave the proper rescue equipment to be able to assist the other(8) in case of emergency."

\section{FACIITY REQUIREMENT SOURCE: 29CFR1910 Part 134(e)(3)(ii)}

"Wban self-contained brathing apparatus or bose masks with blowers are used in atmospheres immediately dangerous to lifo or health, standby men must be preseat with sulitable rescule equipment."

\section{FACILIY REQUIREMENT SOURCE: 29CFR1910 Part 134(e)(3)(iti)}

"Persons using air lipe respirators in atmospberes immediately bazardous to life or beslth shal] be equipped with safery bartusses and soffety lines for lifting or removing persons from hezardous atmosphteres or other and equivaleat provisions for the rescue of persons from hazardous atmospheres ghall be used. A standby min or men with suitable self-contained breathing apparatus stall be at the Dearest fresh air base for emergency rescue."

\section{FACRITY REQURREMENT SOURCE: 29CFR1910 Part 134(e)(5)(i)}

"Every respirator wearez shall receive fitting instructions including demonstrations and practice in how the respirator stoutd be word, bow to adjust it, and how to thetermine if it fits properly. Respirators shall not be worn when contutitions prevent a good frce seal. Such conditions may be a growth of beard, sideburins, a skutl cap that projects under the facepiece, or temple pieces on glasses. Also, the absence of one or both deatures can seriously affext the fit of 2 facepiece. The workes's diligence in observing these factors shall be evalunted by periodic check. To assure proper protection, the facepiece fit shall be cbeciked by the wearter each time he puts on the respirator. This may be done by following the manufacturer's facepiese fitting instructions."

\section{FACILITY REQUIREMENT SOURCE: DDE/EH(0135 IH.3.9}

"9. Proper personnet protective equipment is available, its use is enforce. and proper training for its use is provited."

\section{FACILITY REQURREMONT SOURCE: DOE/EH0135 WS.3.9}

- 9. A documented respizatory protection program, complying with ANSI Z88.2-1980, and 29 CFR 1910.134 has been implemented to ensiru optimum protection against internal exposurs of workers to toxic materials, including radioactive substances."

\section{FACIUITY REQUIREMENT SOURCE: DOE3480.10 Section 9.a(3)}

"Employees should be required to: (a) observe atl safety and heatth nules; (b) use all prassribed personal protective equjpment; (c) follow established 


\section{REQUIREMENTS IDENTIFICATION DOCUMENT HIGH LEVEL WASTE STORAGE TANK FARMS Occupational Safety and Health}

health and safety practices and procedures; and (d) notify sapervisors immediately of suspected exposures to harmiul agents or conditions."

\section{FACIIIY REQUIREMENT SOURCE: DOES480.10 Section 9.c(4)(e)}

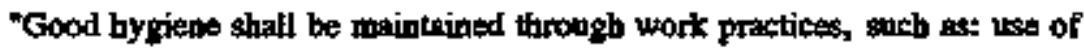
protective cloching; availabilty of showers and chenge rooms; bans on eating, drinking, and smoking in regulated areas; and use of nonpermesble work surfaces."

\section{FACIIIY REQUIREMENT SOURCE: WAC-296-24 Section 07501}

\section{"(1) Application}

(a) Protective equipment, including persental procective equipment for eyes face, head, and extremities, protective clothing, respirstory devices, and protective shields and barritrs, shaft be provided, used, acd maintained in a sanitary an reliable condition wherever it is necessary by reason of hazards of processes or eavironment, chemical hazards, reciological bazards, or mechanical irritants encountered in a manner capable of cesusiag injury or impairment in the function of any part of the body through ahsorption, inhalation of physical contact.

(b) Employes owned eqtipmeat.

Where employees provide their own protective equipment, the earployer shalt be responsible to arsure its adequacy, including proper maintenence, and saritation of such equipreent.

(c) Design. All persond protectuve equipment stall be of safe design and construction for the work to be performed. *

Facility and_Equipnent_Safety Inspections_and Maintenance

This sub-tement addresses the requirements for establishing the programmatic controls nacessary for performance of facility and equipment maintenance while minimizing the oscurrence of safety haxards. This zub-element also addresses the requirements for establishing toe programmatic controls atcessory to enstre periodic inspections of ficilities and equipment are conducted to identify and prevent safery bazards.

\section{FACILITY REQUIREMENT SOURCE: 29CFR1910 Part 120(b)(4)(iv)}

-The site safety and bealth plan, as a minimum shall address the following: Effectiveness of site safaty and health pian. Inspections shall be conducted by the site safery and health stupervisor or, in the absence of that individual, another individual who is knowledgeable in occupationsil sefecy and health, acting on behalf of the employer as aecessary to deternine the effectiveness of the site safety and bealth plan. Any deficiencies in the effectiveness of the site safexy and health plan shail be corrected by the employer." 
WHC-EP-6750

\section{REQUIREMENTS IDENTIFICATION DOCUMENT HIGH LEVEL WASTE STORAGE TANK FARMS Occupational Safety and Health}

\section{FACILITY REQUTREMENT SOURCE: 29CFR1910 Part t20(k)(9)(i)}

"Personal protective clothing and equipment. Protective cloching and equipment shall be decontaminated, clerged, latiodered, maintained or replaced as needed to maintain their effectiveness."

\section{FACIITY REQURREMENT SOURCE: 29CFR1910 Part 120(k)(5)(ii)}

-Personal protective cloching and equipment Employses wbose non-impermeable clothing becomes wetted with hazantous substences shall immediately jemove that elothing and proceed to shower. The clothing shall be disposed of or decontiminated before it is removed from the work zone."

\section{FACILITY REQUIREMENT SOURCE: 29CFR1910 Part 120(k)(0)}

"Unauthorized empioyees. Unauthorized employees siall not remove protective clothing or equipment from change rooms."

\section{FACILITY REQUIREMENT SOURCE: 29CFR1910 Part 120(k)(7)}

"Commercial laundrites or cleaning establishments. Commercial lauodries or cleaning establishments that decontaminate protective clothing or equipruent stal] be informed of the poteatial harnful effects of exposures to bazardous substances."

\section{FACIIIT REQUTREMENT SOURCE: 29CFR1910 Part 120(k)(8)}

"Strowers and change rooms. Wbere the deccotamination procedure indicates a need for regular showers and change roons outside of a contaminated arta, they shall be provicied and aneet the requirements of 29 CFR 1910.141. If temperature cooditions prevent the offective use of water, then other effective means for cleansing shall be provided and used."

\section{FACILITY REQUIREMENT SOURCE: 29CFR1910 Part 120(n)(1)(1)}

"An adeguate supply of potable water sball be provided on the site."

\section{FACILIY REQUTEMENT SOURCE; 29CFR1910 Part 120(n)(1)(ii)}

"Portable containers used to dispense drinking water shyl be expable of being tightly closed, and equipped with a tap. Water shall noc be dipped from containers."

\section{FACILITY REQUIREMENT SOURCE: 29CFR1910 Part 120(n)(1)(fii)}

"Any container used to distribute drinking water shall be clearly marked as to the nature of its contents and wot used for any other purose."

\section{FACILITY REQUIREBENT SOURCE: 29CFR1910 Part 120(n)(1)(iv)}

"Where siogle service cups (to be used but once) are suppilied, botb a sinitiry continer for the unused cups and a receptacle for disposing of the used cups shall be provided." 


\section{REQUTREMENTS IDENTIFICATION DOCUMENT HIGH LEVEL WASTE STORAGE TANK FARMS \\ Occupational Safety and Health}

\section{FACILFTY REQUIREMENT SOURCE: 29CFRI910 Part 120(n)(2)(1)}

-Nonpotuble water. Outlets for nonpotable water, such as water for firefigbting purposes, shal] be identified to irdicate clearly that the water is unsefe and is not to be used for drinking, washing, of cooking purposes."

\section{FACILITY REQUIREMENT SOURCE: 29CFR1910 Part 120(n)(2)(i)}

\section{$n$}

Nonpotable water. There shalt be no crosseconpection, open or potential, between a system furnishing potable water and a system furnisking nonpotable water."

\section{FACILTY REQULREMENT SOURCE: 29CFR1910 Part 120(n)(3)(ii)}

"Under temporary field conditions, provisioas shall be made to assure that at least one toilet facility is available."

\section{FACILITY REQUIREMENT SOURCE: 29CFR1910 Part 120(n)(3)(iit)}

"Hazandous waste sites not provided with 2 sanjiary sewer stall be provided with the following toilet factlitios unjess prohítited by local codes:

(A) Cherrical toilets:

(B) Recireulating toilets;

(C) Combustion toilets; or

(D) Flust toiters."

\section{FACILITY REQUIREMENT SOURCE: 29CFR1910 Part 120(n)(6)}

"Washing tacilities. The employer shall provide adequate washing facilities for employees engaged in operations where hazartous strbstances may be harmfitl to employees. Such facilities shall be in near proximity to the worksite; in arees where exposures are below permissible exposure limits and published exposure levels and which are under the controls of the employer, and shlitl be so equitpped as to enable taployees to remove hazardous substances from inemselves."

\section{FACILITY REQUIREMENT SOURCE: 29CFR1910 Part 120(n)(7)}

"Showers and change nooms. When kazordous waste clean-up or removal operations commence on a site and the duration of the work will require six months or greater time to compiete, the employer shall provide stowers and change rooms for all employees exposed to hazardous substances and heath hazards involved in bazardous waste clean-up of removal operations."

\section{FACILITY REQUIREMENT SOURCE: 29CFR1910 Part 120(n)(7)(it)}

"Change rooms shall be provided and shall meet the requirements of 29 CFR 1910.141(b). Change rooms shall consist of two separate change areas separated by the shower area required in paragraph (nX)(T)(i) of this section. One ctange area, with an exit leading off the worksite, sball provide empioyees with a cien area where they can remove, store, and put on strtet 


\section{REQUIREMIENTS IDENTIFICATION DOCUMENT HHGH LEVEL WASTE STORAGE TANK FARMS Occupational Safety and Health}

clothing. The second area, with an exit to the worksite, shall provide employees with an area where they can put on, remove and store work clothing and personal provective equipment."

\section{FACHITY REQUIREMENT SOURCE: 29CFR1910 Part 120(n)(7)(il)}

"Showers and change rooms shall be located in areas whers exposures art below the permissible exposure limits and published exposure levels. If this cannot be accomplished, then . 2 vectilation system shall be provided that will supply air that is below the permissible exposure limits and publisined exposure levels."

\section{FACILITY REQUIREMENT SOURCE: 29CFRI910 Part L20(n)(T)(iv)}

"Employers shall assure that employees shower at the end of their work shift and when leaving the bazandous waste site."

\section{FACILITY REQUIREMENT SOURCE: 29CFR1910 Part 147 (c)(0)(i)(A)(B)(C)(D)}

\section{- Lockout and Tagout}

The employer stall conduct a periodic inspection of the energy control procedure ar lenst annually to ensure that the procedure and the requirements of this standard are followed. (A) The periodic inspection shall be performed by an autborized employes otber than the one(s) utitizing the energy control procedure being inspected. (B) The periodic inspection shall be conducted to correct any deviations or inadequecies identified. (C) Where lockout is used for energy control, the periodic inspection shall irclude a roview, between the inspection and each authorized enployed, of that employes's responsibilities under the exergy control procedure being inspected. (D) Where tagout is used for energy control, the periodic inspection shall include a roview, between the inspector and each anthorized and affeeted employee, of that employee's responsibilities under the energy control procedure being inspected, and the elemenis set forth in paragraph (c)(7)(ii) of this section."

\section{FACILITY REQUREMENT SOURCE: 29CFR1910 Part 147 (c)(0)(ii)}

"Lockout and Tagout

(ii) The employer shall certify that the periodic inspections bave beon performed. The certification shall identify the machine or equipment on which the energy control procedure was being utilized, the date of the inspection, the employees included in the inspeation, and the person perforrming the inspecton."

\section{FACIITY REQUTIENENT SOURCE: 29CFRI910 Part 147 (9)(1)}

\section{"Lockout and Tagout}

(i) Additional requirements, (1) Testing or posicioning of machines, equipment or compenats thereof. In situations in which lockout ar tagout devices must be temporarily removed from the energy isolating device and the machine or equipment energized to test or position the prechine, equipment or component thereof, the following sequence of actions shall be followed: (i) Clear the angchine or equipment of tools and materials in accordance witb paragraph (e)(1) of this section; (ii) Remove employees from the machine or equipment area in accordance with paragraph (e)(2) of this sectuon; (iii) Remove the lockout or tagout dovices as specified in paragraph (e)(3) of this section; (iv) Energizes and proceed with testing or positioning; (v) 


\section{REQUIREMENTS IDENTIFICATION DOCUMENT \\ FIGH LEVEL WASTE STORAGE TANK FARMS Occupational Safety and Health}

Deenergize all systems and reapply energy control measure in accortance wich paragraph (d) of this section to continue the servicing and/or matintenance."

\section{FACEITY REQUIREMENT SOURCE: 54FR3904 Part (c)(3)(Iv)}

"Establish a medical program which includes availability of first aid on site and of physician and emergency medical cars nearby, so that harm will be minimized if an injory or illeess does ocedr."

\section{EACILITY REQUIREMENT SOURCE: DOE/EHO135 PP.3.3}

3. Periodic inspection and maintenance programs are established for all mechanical/engiseered contaminant control systems.

\section{FACILITY REQUREMENT SOURCE: DOE/EH0135 WS.4.10}

"10. Personnel are awrare of and follow procedures for lockout and tagout to prevent accidental contact with energized electrical circuits and other hazardous energy sources, in accordence with 29 CFR 1910. 147."

\section{FACITITY REQUIREMENT SOURCE: DOE/EHOL35 WS.4.12}

-12. Hand and portable power tools, and other hand-hejd equipment meet the requirements of 29 CFR 1910 Subpart P."

\section{FACILITY REQUIREMENT SOURCE: DOE/EH0135 WS.4.4}

"*4. Guarding is available and in place, as specified in 29 CFR 1910, Subpart $O$ for moxthines and toois with moving and rotating parts that may present workplact safety concerns."

\section{FACILITY REQUIREMENT SOERCE: DOW/EH0135 WS.4.6}

- 6 . There is an inspection and preventative maintenante program for powered platforms, boistiog and rigging tevices, cranes and other powwered tools and machinery. Operational procedures are in compliance with the DOE Hoisting and Rigging Manual, and 29 CFR 19j0, Subparts $F$ and N.*

\section{BACILITY REQUTREMENT SOTRCE: DOE/EH0135 WS.4.7}

"7. Compressed gas containers and other high pressure systems are inspexted, stored, and maintajned to mínimizo cecupational satety concerns in sccordance with 29 CFR 1910, Subparts $H$ and M."

\section{FACILITY REQUIREMENT SOURCE: DOB3790.1A Chapter VII, Section \$.b}

-Preplacement Health Evaluation. Prior to employment, where a bazard is 2ssocizted with fob performante, each employee shall have a complete health ovaluation, with specisl entuphas placed upou the health and physical factors 


\section{REQUIREMENTS IDENTIFICATION DOCUMENT HIGH LEVEL WASTE STORAGE TANK FARMS \\ Occupational Safety and Health}

that relate to the hazards of the position. Tae purpose of this examination is to determine an employes's bealth stans prior to any exposures associated with a job. In addition, it ts to determine the employes's physical capabilities and any required acommodations necessary for safe and healthy job performance. The bealth evatuation sthall be performed by the health services staff at no cost to the eifployee."

\section{FACILITY REQUIREMENT SOURCE: DOE3790.IA Chapter VII, Section 5.n}

"Reporting Requirements.

(1) Heads of Fiald Orgenizations, the designated Headquarters official, or designes, shall be atvised of the results of exch health evaluation performed on one of their employees which contains menaingful dam relative to physicsl limitotions ind/or work restrictions in order to ensure safo placement of the entrployes.

(2) A monthly summary of the types of treatireats performed by the health services staff shall be subcuitted to the safety and health official of each field organization or Headquarters as appeopizate."

\section{FACIIITY REQUIREMENT SOURCE: DOF3790.1A Chapter VII, Section S.0}

-Medical Reconds.

(1) Fisld Organizations shall maintain records of employee medical examinations in accondanse with instructions of the Office of Personnel Manzgenent in the Federal Personnel Manual, chapter 339; DOE 1700.1; and DOE 1800.1A.

(2) Medical records and professionel evaluations of curreat employees and persons selected for appointment will be mointained under the control of bealth service personnet and for use only by professional personnel, industrial bygienists, and health physicists."

\section{FACIITY REQUREMENT SOURCE: DOE5480.10 Section 9.b(0)}

Medical Monitoring. The industrial bygiene staff sball inform the medical ortganization of potential and axisting bealth hazords identified, the results of hamard evaluations, and other industrial bygient information needed for operation of a medical monitoring program. The industrial hygiene staff shonld be available to accompany medical staff on periodic wotissite visits (refer to DOE 5480.8))."

\section{FACILTY REQUIREMENT SOURCE: DOES480.19 Chapter IX, Section C.8.}

-Periodic Inspections

Periodtc Inspections. C.8. Periodic inspections should be conducted by autborized personnel, supervisor, or appropriate mangger, to determine whetber procexhures are being followed and to correct any deviations or ipadequacies observed. Inspections shotld include a review of the responstbilities of personned and supervisors. The supervisor ar appropriate manager stould certify that the periodic inspections bave been performed, doctureating the equipurant and procedures involved, dates of inspection, personnel participating in the inspections, and personnel performing the inspections." 


\title{
REQUIREMENTS IDENTIFICATION DOCUMENT HIGH LEVEL WASTE STORAGE TANK FARMS Occupational Safety and Fealth
}

\author{
FACILITY REQUIREMENT SOURCE: WHC-SP-0708 Chapter 9, Section 5.8
}

"Tasting or Positioning of Equipment. Temporary removal of lockout and tagout devices shall be diseouraged. However, situations in which bockout and tagout devices must be temporarily removed and the equipment entrgized, the foilowing sequence of operations shall be foilowed: 5.8.1 Removal must be approved by supervisor. S.8.2 Clest the equipment of tools and materials. 5.8.3 Removs personned from the equipment area. 5.8.4 Remove the lockout and tagout device as disected by procedure. 5.8.5 Energize and proceed with testing or positioning. 5.8.6 de-energize all systems and reinstalt lockout and agout. This lockout and tagout shail be controlled and dxetmented with the same rigor as used in the origingl lockout/tagont."

\section{OCCUPATIONAL HEALTH PROGRAM}

This efement describes the basis of an effective Occenpational Medical Program. The Oecupational Medical Program is desiged apd operated to protect and enthence the physical and mental bealtib of employees and to promote public bealth.

\section{FACILITY REQUIREMENT SOURCE: 29CFR1910 Part 120(b)(3)(v)}

The comprebersive workpian shall provide for the implementation of the required informational programs requized in paragraph (i) of this section."

\section{FACUITY REQUIREMENT SOURCE: 29CFR1910 Part 120(b)(4)(ii)(D)}

"The site safety and bealth plan, as a minimum shail address the following: Medical surveitlance requirements in accordance with the program in paragraph (f) of this section-"

\section{FACILITY REQUIREMENT SOURCE: 29CFR1910 Part 120(0)(1)}

"Medical survejl[ance. General. Enployers engaged in aperations specified in paragraphs (a)(1)(i) through (a)(I)(iv) of this section and not covered by (a)(2)(iii) exceptions and employers of amployees specined in paragraph (q)(9) shall instinute a medical surveitlance program in accordance with this paragraph."

\section{FACILITY REQUIREMENT SOURCE: 29CFR1910 Part 120(f)(2)}

"Employees covered. The medical surveillance program shall be instituted by the employer for the following enpiloyees: (i) All employees who are or may be exposed to bazardous substances or health hazards at or above the permissible exposure limits, or, if there is no peranissible exposure limit, above the published exposare levels for these substances, without regard so the use of respirators, for 30 days or more a year;

(ii) Al employees who wear a respirator for 30 days or more a year or as requited by $\$$ 19t0.134;

(iii) All employess who are injured, become ill or devetop signs or symptoms due to passible overexposure involving hazardaus substances or beslth betzards trom an emergency response or hagardous waste operation; and

(iv) Members of HAZMAT teams. " 


\section{REQUIREMENTS IDENTIFICATION DOCUMENT HIGH LEVEL WASTE STORAGE TANK FARMS Occupational Safety and Health}

\section{FACILITY REQUIREMENT SOURCE: 29CFR1910 Part 120(n)(5)}

"Extamination by a physician and costs. All medical examinations and procedures shatl be performed by or undex the supervision of a licensed physicien, preferably one knowledgeable in oceupational medicine, and shall be provided without cost to the employes, without loss of pay, and at a reasonable time and place."

\subsection{Henlth Examinations}

This sub-element addresses the requirements to provide employes with comprehensive health examinations. Comprehtedsive bealth examinations shall assess the beolth of workers to ensore proper placement and reteotion of workers in positions commensurate with their physieal, atents], and emotional capactities.

\section{FACILITY REQUUREMENT SOURCE: 29CFR1910 PAST 120(f)(3)}

"Frequency of medical examinations and cossultations. Medical examinations and coasultations shall be made available by the employer to each employe sovered under paragraph (1)(2) of this section on the following schectules:"

\section{FACLITY REQUEREMENT SOURCE: 29CFR1910 Part 120(0)(3)(i)}

"Frequency of medical examinations und consuitations. For oroployes covered under paragraphs (O)(Z)(i), (D)(2)(ii), and (f)(2)(iv):

(A) Prior to assignment;

(B) At lesst once every twelve morths for each exployee covered unless the attending physician believes a longer interval (not grester than biennially) is appropriate;

(C) At termination of expployment or renssiganent to an area where the employee would not be covered if the employee has not had an examination within the last six months;

(D) As soon as possible upon notification by an employee that the employee bas developert signs or symptoms indicating possibie overexposure to bazardous sobstnnces or health bazards or that the employes has been injured or exposed above the permissible exposture limits or published exposure levels in an emergency situation;

(E) At more frequent times, if the examining physician determines that an increased frequency of examination is medically necessiry."

\section{FACILITY REQULREMENT SOURCE: 29CFR1910 Part 120(f)(6)}

"Infarmation provided to the physician. The employer shall provide one copy of this stenderd and its ippendixes to the attending physician, and in addition the following for each employee:

(i) A description of the employee's duties as they relate to the traployee's expostres.

(ii) The employee's exposure beveis or anticipated exposure levels.

(iii) A description of any personal protective equipment used or to be used.

(iv) Information from previous medical examinations of the employes which is not readily aviilable to the exarnioing physician.

(v) Information required by $\$ 1910.134^{*}$ 


\title{
REQUIREMENTS IDENTIFICATION DOCUMENT HIGH LEVEL WASTE STORAGE TANK FARMS Occupational Safety and Fealth
}

\author{
FACILITY REOUREMENT SOURCE: DOE/EH0135 MS3.5
}

"5. Medikal screening and testing of new, continuing and former amployees assures that the bealth of employees is adequately controlled."

\section{FACIITY REQUIREMENT SOURCE: DOE3790.1A Chapter VII, Section 5.b}

"Preplacement Health Evaluation. Prior to employment, where a hazard is associated with job performanco, tach entrioyes shall bavo a complete bealth evaluation, with special emphass placed upon the bealth and physical factors that retate to the hazards of the position. The pupose of this examination is to determina an employee's healtb status prior to any exposures associsted with 2 job. In addition, it is to determige the employee's physictil capabilities and any required ocoomonotations necessary for sofo and healthy job performance. The heslth evaluation shall be performed by the bealth services staff at no cast to the employee."

\section{FACILITY REQUIREMENT SOURCE: DOE3790.1A Chapter VII, Section 5.e}

"Health Screening Evaluation. Each tomployeo ags 45 and over shall be offered a complete bealth avaluation annually at wo cost to the employes."

\section{FACILITY REQUIREMENT SOURCE: DOE3790.1A Chapter VII, Section 5.d}

"Job Clange or Transfer Health Evahtation.

(1) Employes who change or transfer job functious with associated bazands (e.g., elextrician to finemin or linertan to crane operator) shall bave their health status and physical fitress reviowed with emphasis on the affects of the position vacated and the healib and physical factors that relate to the new job tasks and demands. The evaluation shail be at no cost to the employee.

(2) Employees who change or transfer from a job function with associated hazreds to a job funcion with negligible associated hazards of vice versa (e+g., courier to file clesk of draftsman to lineman) shall tave their bealth status and physical fitness reviewed with emplasis on the effects of the position vacated or the health and physical factors that relate to the dew job tasks and demands, for whichever involves hazards. The evajuation shal] be at no cast to the employea."

\section{FACILITY REQUIREMENT SOURCE: DOE3790.IA Chapter VIII, Section 5.e}

"Retirement or Sepsration Heath Evaluation. The health status of an employee who is retiring or separating from a position where there is an associated bazard shall be deternined by a beolth ovaluation, with emphessis placed upon the bealth and physical factors of that position. The evaluation shall be at po cost to the employee."

\section{FACILITY REQUIREMENT SOURCE: DOE3790.1A Chapter VII, Section 5.f}

"Renurn to Work (Fitness-tor-Duty) Evaluation. An employee who occupies a 


\section{REQUIREMENTS IDENTIFICATION DOCUMENT HIGH LEVEL WASTE STORAGE TANK FARMS \\ Occupational Safety and Health}

position with an associzted hazard, who is absent from wotk more than 3 consecutive workdays due to either an occupationgl or a nonoceupational illness or injury, shall submit either a bealth status repont from a personal pbysician (obdained at the employee's expense) to the employee's supervisor stating that the enployee is fit to work, ar sholl nodergo a bealth ovaluation by the bealth services (at no cost to the employee) sufficient to ensure that the smployee's return to work will be without undue bealth hazsird or accident risk to the employes or othars."

\section{FACILITY REQUIREMENT SOURCE: DOE3790.IA Chapter VII, Section 6}

NONMANDATORY COMPONENTS. In order to enhage the Federal Employe Occupational Medtal Program, the fotlowing optiontl hedth screening is suggested:

a. Employees under age 45 may bo offered 2 complete health evaluation on a space-avajlable basis at no cost to the employee.

b. Employees in a hazardoas occupation should be given priority consideration

for bealth ovaluations.

\section{FACILITY REQUREMENT SOURCE: DOE5480.10 Section 9.b(0)}

"Medical Monitoring. The industrial hyigiene staff shall inform the medical organization of potential and existing health hazards jdentified, the results of bazatd evaluations, and other industrial hygiene information needed for operation of a medical monitoring progran. The industrial bygiene staff should be available to accompany medical staff on periodic worksite visits (refer to DOE 5480.8))."

\section{FACILITY REQUIREMENT SOURCE: DOES4\$0.10 Section 9.f(5)}

"Industrial hygieno hazard ioventories, reports, and monitoring data shall bo readily accersible to the medical organization responsible for operating the medical monitoring program. Records aceess shall be provided to employes or designtted representatives of employes in accordence with OSHA Regulation 29 CFR 1910.20 and DOE Privacy Act Regulation 10 CFR 1008.17(b)(3)."

\section{FACWITY REQUIREMENT SOURCE: DOE5480.8A Section 11.b(1)}

"Shall be a physician who is a gradusto of an accredited school of medicine or osteopatby and who meets the lixensing requirements applicable to the locetions in which the physician works. Board certifieation in oceppational medicine is preforted."

\section{FACEITY REQUTREMENT SOURCE: DOE5480.8A Section 11.b(2)}

"(2) Comprehensive Health Examination Contedt. The comprehensive health examinntion stiall be condituted by an OHE wider the direction of a licensed physician, using whatever ancillary assistance is beeded in aecordance with current, sound, and acceptable medical practices. The minimum content is 


\section{REQUIREMENTS DFNTIFICATION DOCUMENT HIGH LEVEL WASTE STORAGE TANK FARMS Occupational Safety and Health}

described for the preplacement of other required comprebensive exeminations. Additions way be peeded, as determined by the Site Medical Director, considerting the purpose(s) of the extmination, bealth hazards of curreat and former tomploymint, and persond health-risk factors.

(a) Medical History. The medicil history shall include tuformation concerning the employes's current illmess or besith stines, review of systems, past medical history, occupational history, review of a current job task analysis, family bistory, immunization bistory, sunking and other lifestyle factors, allercy history, trevel history, and history of mental or emotional disoters.

(b) Physical Examination. The physical examination stall inclade an evaluation of head, aeck, eyes, ears, nose, throat, mouth, heart, Jungs, abdomen, genitourinary system, vaseular and Jymphatic systems, skin, musculoskeletal system, a brief netrological examination, and a measurement of baight, weight, pulse and blood presture. A digital recial and prostate examination shall be offered to males age 40 and above. Both 2 pelvic and breast examination siall be offered to females. It atay include mamnoography, a pap swear, sigmoidoscopy, and tonornetry over 34 years of age to conform to goed preventive medicine prectices. When the resoutces and capability will not permit the performance of these specialized examinations, the employes is to be advised as to their value and urged to obtain them from a parsonal physician.

(c) Laboratory Studies. The basic laboratory work shall includer

1 Vision testing fo irelude pers, distant, oolor vision, depth perception, and borizontal peripherel field of vision);

2 Complete blood count and blood chemistry profite;

3 Uripalysis and serology when indicated;

4 An audiogram as a basoline, thet overy 3.5 years unless exposed to noise at or above $B 5$ decibels, then anntrally;

5 A poimonary function test as a baseline, then every 3-5 years uniess exposed to petmonary initants, a history of pulmonary disease, or when OHE deems it necessary; 
WHC-EP-0750

\section{REQUIREMENTS IDENTIFICATION DOCUMENT HGH LEVEL WASTE STORAGE TANK FARMS Occupational Safety and Health}

6 An electrocardiogram as a baseline, then annually for over ago 50, a history of heart disease, or when OHE deems it necessary; and

7 Oher labocatory wests required by OSHADOE sball bo obtained.

(d) Guidelines for Use of X-rays. The recommendations and guidance contained in 43 FR 4377 , of 2-1-78, should be

$\therefore$. considered. All radiogeaphs shall be interpreted by a qualified radiologist or as specilied by OSHANDOE.

(o) Review and Evaluation of Examination. The OHE strall discuss the results of the examination with the employee. The OHE shalt provide bealth counseling and advice, especially $2 s$ related to risk tartors that may cause prearahure morbidity or mortality. Employees shill be encouraged to have private physicians and should be referred to private physicians for any necessery definitive cart or followap treatment, and for any necessary additional diagnostic studies that are beyond the scope of the occupational health exantination. The health intercsts of employees are best served by close communtication and coaperation beween private and occupational heslth physicians."

\section{FACHITY REQUIREMENT SOURCE: DOE5480.8A Section 11.b(3)(a)}

Preplacemeat Evaluations.

I A medical evaluation of an individual shalt be contucted after the job offer, but prior to the performance of job duties, and in the case of an employes, prior to a job transfer. The health status and fitness for derty of the individual shall be deteroined, thersby assurtage that assigned duties can be performed in 2 safe and reliable manner and consistent with the Americans with Disabilities Act of 1990.

2 Contrator rranagement shall provide to the Site Oceopational Medical Dirseter a job task analysis pertaining to the applicant/employee to enable the medical examiner to assess the individual as required in $11 b(3)(a) 1$.

3 The scope of the inisial preplacernent evaluation shall be a comproftensive examination as outlined in paragraph 11b(2). The Site Oxcupational Medtcal Disector shall determine additional sxamination conteot, considering such tectors as special physical or mental requirements of the job, potential bazardous exposures, or medical surveillance requirements mapdated by the Oecupational Safety and Health Act, 29 CFR 1910 or 29 CFR 1926.

4 Those contractor operations requiring large numbers of preplacement 


\section{REQUIREMENTS IDENTIFICATION DOCUMENT HIGH LEVEL WASTE STORAGE TANK FARMS Occupational Safety and Health}

evaluations may defer the comprehensive evaluation of individuals not assigued to bazandous work or potentially bazardous exposures after a review of the individual's medicel history. The evaluation shall be performed within 6 months of the hire date.

5 The acenpational medical departmeat shal be informed of all job transfors. The Oceupational Medical Dirtctor or desigpee should determine whether a medical ovaluation is necessary."

FACILITY REQUIREMENT SOURCE: DOE5480.8A Section 11.b(3)(b)

-(b) Medical Surveilionce Exanimations and Health Monitoring. Staddards and requirements for special bealth examinations and beaith monitoring of employes who work in jobs involving specific physical, chemital, or biological hazards shall be in accortance with appliczble OSHAJDOE stondards. When employees are exposed to poteatial tazands not covered by regulations, appropriate special examinations may be required as determined by the Site Medical Director and approved by the DOE Director, Office of Occupational Medicine."

\section{FACILITY REQUIREMENT SOURCE: DOE5480.8A Section 11.b(3)(c)}

"(c) Qualification Examitzations.

1 Examinations shall be conducted to qualify employes for specific job assigmments for which specific medical qualifiestion stapdiards exist (e.g.. drivers, pitots, protective force personnel, and respirator wearers).

2 Special medical evaluations shall be performed in repponse to contracter management's request to deteruine employee fimess for duty."

FACILITY REQUIREMENT SOURCE: DOES480.8A Section 11.b(3)(d)

(d) Voluntary Periodic Examínations. Voluntary periodic axaminations shall be offered; however, it shotld be recognized that specific work hazards or statutory requirements as outlined in $11 \mathrm{~b}(\mathrm{~J})(\mathrm{b})$ and $1 \mathrm{je}$ may dictate more frequent health examinations to maintain an effective occupational medical program. A fandamental purpose of these examinations is to provide employees with the periodic assessment of their bealth. Accordingly. rejevant componeats of the compreinensive examination, paragraph $11 \mathrm{~b}$ (2), may be included, as wel] as other preventive bealth measures such as health-risk appraisals or wellness coumseling as muthorized by the Site Medical Director.

1 Eaupioyes age 50 and over shalt be offered a biennial health axemination. Conatent shall be based upon guidelines established by the Site Medical Director, considering work assignmnent and individual risk factors.

2 Empiloyes age 40.49 shall be offered a health 
WIC-FP+0750

\section{REQUIREMENTS IDENTIFICATION DOCUMENT HIGH LEVEL WASTE STORAGE TANK FARMS Occupational Safety and Fealth}

examination every 3 years.

3 Explayees under age 40 stall be offered 2 health examination every 5 years."

\section{FACILITY REQUIREMENT SOURCE: DOE\$480.8A Section I1.b(3)(e)}

"(o) Return-tro-Work Health Evaluations.

I Opcupational Injiry or Illoess. All enployees with occupationally-rellated injuries or illoesses shall be evaluated before returning to work. The scope and content of this evaluation shall be determined by the OHE, based upon the nature and extent of the injury or disease, and shall be sufficient to ensure that the employee may return to work without undue bealth risk to self or otbers. Written clearance from the oecuparional medical department shall be required before such an extoloyeo may return to work.

2 Nonoccupational miury or Illness. Contractor manageroent, in the following situations, shall ensure that employes will not bi allowed to rotum to work tintil they receive a hes/th evaluntion and written cleasance from the oceupational medical department. Situations warranting ovaluation and clearence include nonoccupationat-related itnesses or injuries causing absence from work for 5 consecutive workdays or more, procedures or treatments that woutd affect negatively the eroployee's ability to perform in a safe and relisble manner, and hospitalization. The employee shall provide refevant mesical information from their privale physicion to assist in this determination. The final decision for heath-related work recommendations shalt reside with the Sits Medical Director if a disagreament exists regarding return-to-work suitability."

FACILITY REQUIREMENT SOURCE: DOE5480.8A Section 11.b(3)(O)

"(f) Termination Health Evaluations. A health status review shall be made available for all terminating employes. Based upon the information obtained. 2 health exanination (the content to be determined by the Site Ocespational Medical Director) shall be conctucted, whenever possible, on empiloyees with known octupational illnesses or injuries, documeated or presumed expostres requized by OSHA reguiations, or when ntore than 1 year bas elapsed gince the last examination. This should include a review of the medical record. associated exposure informstion, and a signed response by the employee to each of the following questions:

1 Have there been recent occupationad jilnesses or injuries not previously reported?

2 Have you ever been inforded of an exposure to radiation or toxic materials above permissible limits?

3 Do you have any complaints or concerns related to prior 


\section{REQUIREMENTS IDENTIFICATION DOCUMENT HIGH LEVEL WASTE STORAGE TANK FARMS Occupational Safety and Fealth}

illinesses, injuries, of exposures?

4 Do you have any current medical complaints?"

Heallih Maintenance and Prepentipe Medicine

This sub-element addreses the requitements for providing employes with health maintenance and preventive maintenance care. These activities will hejp increase workes effectiveness through preservation and improvement of worker health. Specifically, the Occupational Medical Program shall provide continuing health education and promote overall fimess.

An Employes Assistence Program (EAP) shall be establisted to provide rehabilitation assistance to employeas who need help with alcobol/dring abuse andiof psychological problems.

\section{FACILITY REQUIREMENT SOURCE: 29CFR1910 Part 120(D(7)(i)}

"Pbysictan's written opinion. The mmployer shall obtain and furrish the enfployes with a copy of a written opinion from the attending physician containing the following:

(A) The physicion's opinion es to whether the employes las any detectable medical conditions which would place the employee at increased risk of material impairment of the employee's health from work in hazarikous.waste aperations ar emergency response, or from respirator use.

(B) The physician's recommended limitations upon the employee's assigned work.

(C) The results of the medical examination and tests if requested by the employer.

(D) A statement that the enployee has been informed by the physician of the results of the medical examination and any medical conditions which requirs further examination or treatmosat."

\section{FACILITY REQUIREMENT SOURCE: 29CFR1910 Part 120(h)(7)(i)}

"Pbysicians written opinion. The written opintion obtained by the empioyer shail ont reveal specific fordings or diagnoses unretated to occupational exposures."

\section{FACILITY REQUIREMENT SOURCE; DOE/RH0135 MS.5.4}

"4. An active health auareness and wellness program is implemeoted at the sitedfacility."

\section{FACILITY REQUTREMENT SOURCE: DOE3790.1A Chapter VII, Section 5.h}

"Screening Exarminations. Tests and ingunizations for specific disenges shal! be provided as necessiry by heolth services personnel."

\section{FACIIITY REQUIREAENT SOURCE: DOE3790.1A Chapter VIII, Section 5.i}

"Health Education and Cotnseliog, provided at oo cost to employees, shall inclute:

(I) Leckures on health and fieslth education maberials to promole and 


\section{REQUIREMENTS IDENTIFICATION DOCUMENT HIGH LEVEL WASTE STORAGE TANK FARMS}

\section{Occupational Safety and Health}

encourage employees to improve and maintain personal health;

(2) Individual counseling on health matters; and

(3) Litilization of avaitabie Employee Assistance Program services."

FACILITY REQUIREMENT SOURCE: DOE5480.8A Section 11.d(1)

"EAP and Wellosss Program.

(a) The Site Occupational Medical Director shall review and approve the medical aspects which include physical and meatil health, stress and enotional/bebavioral problems of all contractor-sponsored or sulpported EAP, as well as alcohot and ocher substance abuse rebabilitation programs. Proprem evahurtion actountability skall inclisde treatment processes, records, referrals, treatment outcomes, followup (aftercare programs), and staffing.

(b) The Site Occupational Medical Director stall review, approve and coordinate all contractor-sponsored or supported wellness programs as esseotial componerts of a preveotive medicine program. Health courseling should bo avilable to all employees. Program evaluation and accountability shall address the training/education opportumities provided, tesson plans, class evaluation records, and referralicounseling sessions."

FACILITY REQUIREMENT SOURCE: DOR5480.8A Section I1.d(2)

-Immunization Program.

(a) Tetamus/Diphtberia immunization shall be available for all employes, consistent with Centers for Disease Control (CDC) guidelines.

(b) Enployees inrolved in foreign travel shalt be advised to obtain the inminizations recommeated by CDC and the Fublic Health Senvice of the U.S. Departunet of Heakth and Humin Services.

(c) In the interest of saving lost timpe off the job, elective cart, such as serial denstitizations for allergy, may be gived at the discretion of the Site Occipational Medical Director with the written advice and consent of the employes's private physician.

(d) Using CDC guidelines, influenza vaccins shall be offered to all einployeos.

(e) Hepatitis B vaceine shall bo offered accorting to CDC guidelines.

(f) The Site Occupational Medical Director shall ensure that immunization programs for bloodborne pathogens and biohazordous waste canform to OSHA regulations and CDC guidelines for those employees at jisk to these forms of exposure."

\section{FACILITY REQUIREMENT SOURCE: EEI Chapter II, Section 10}

Thougb an effective poilicy probibiting alcohol and drug abuse is koy to a 


\section{REQUIREMENTS IDENTIFICATION DOCUMENT HIGA LEVEL WASTE STORAGE TANK FARMS Occupational Safety and Health}

effective fitness for duty program, the availability of rehabilitation assistance to individuals wto need it can substantially streogthen such 2 program. Employes Assistance Programs should bejp employes free themselves from drug and alcohod abuse andfor psychological problems and reture to produetiva work.

- Difmenosis and Trentment

This sub-element addresses the proper diagnosis and treatment of employe occupational injury and illmess is essential to tacilitate amployes retabilibation and quick return to work. The Occupational Medical Program stall also provide assistence for employes who become it witite at work (dve to non-occupational reasons). Employess stholl be encouraped to use privite physicians andior medical facilities for diagnosis and treatment of non-aceppational injuries and illesses, thereby reducing facility bealtb costs. In emergencies, employes shalt be given the necessary assistance uatil referral to a private physician or facility is possible.

\section{FACILITY REQURREMENT SOURCE: 29CFR1910 Part 120(D)(3)(A)}

"Frequency of medical examinations and consultations. For empioyees covered under paragniph (f)(2)(iii) and for all ermployees including those of exuployers covered by paragraph (a)(IY(v) wbo may have been injured, received a heallh tmpairment, developed signs or symptoms which may bave resulted from exposure to hazarous substances resulting from m empergency incident, or exposed during an emergency incident to hazardous substances at concentrations above the permissible expostre linutis or the published exposure levels without the necessary personal protective equipment being used:

(A) As soon as possible following the emergensy incident or development of signs or symptoms:

(B) At additional times, if the examining physician determines that follow-up examinations or consultations are medically necessary."

\section{FACLITY REQULREMENT SOURCE: 29CFR1910 Part 120(O)(4)(1)}

"Content af medical examinations and consultations. Medical examinations required by paragraph (f)(3) of this section stall include 2 medical and work history (or updeted history if one is in the employee's file) with spectal owphasis on symptoms rolated to the handling of bazardous substances and beath hazards, and to fitness for duty incloding the ability to weor any required PPE under conditions (i.e., ternpernture extremes) that may be expected at tho work site."

\section{FACILTY REQULEMENT SOURCE: 29CFRI910 Part 120(0)(4)(i)}

"Content of medical examinetions and consultations. The content of medical examinations or consultations mafe available to enployees pursuant to paragraph (f) shall be determined by the altendtisg physicisn. The guidelines in the Oecupational Safety and Health Guidanee Manual for Hazardous Waste Site Activities (See appendix D, Referecce No. 10) should be consulted." 
WAC-EP-0750

\section{REQUTREMENTS IDENTIFICATION DOCUMENT HIGH LEVEL WASTE STORAGE TANK FARMS Occupational Safety and Health}

FACIITY REQUIREMENT SOURCE: DOE/EH0135 MS.3.7

7. Employees receive adequnte medical treatment for occupationgl and nonoceupational injuries and illneseses."

\section{FACILITY REQUIREMENT SOURCE: DOE3790.1A Chapter VII, Section 5.g}

Treatment and Medications. The health services staff stall at their discretion administer the following at $n$ cost tho the enployes:

(1) Vaccioes or other medications furnished by the emplayee ind prescribed in writing by the employes's personal physician as reasonably necessary to maintain the employes's health and well-being while at work; and (2) Treatment prescribed by a pbysician providing medital tare ib performance-of-duty injury or illness cases under the Foderal Employee's Compensation Act."

\section{FACILITY REQUIREMENT SOURCE: DOE3790.1A Chapter VII, Section 5.j(1)}

"Oceupational Injury or Illness. Any employe with an oceupationally related injury or illness shall be initially examined and treated to allay pain, discomfort, and anxitety without undue delay and at no cost to the employes. The scope and content of the examination and treatment shall be bessed upon the gaturs and extent of the injury or illness, and shall be sufficiedt to determine whether the empioyese may return to wark without undus health bazard or aceident risk to the workforce. If necessary, conveyance of the exiployes to a local hoopital emergency coom shall be provided.

\section{FACILITY REQUIREMENT SOURCE: DOE3790.1A Chapter VII, Section \$.j(2)}

"Nonoccupational Injucy or Itluess. On-the-job care is given, at co cost to the employes, as necessary to allay pain, discomfort, and anxiety; to allow corrpletion of the workday, and to provide iaterim cart prior to refarral of the employee to his ar ber physician for private medical attention."

\section{FACILITY REQUIREMENT SOURCE: DOE5480.8A Section 11.e(1)}

(1) Oxcupational Injury or Diseass.

(a) The management of occupational injury or disease shall be in accordance with the laws and regulations of be State in which the facility is located.

(b) Dingnosis and treatmept of cceupational injtry or disense sball be proupt with emptasis placed on rebabilitation end renirn to work at the earliost time compatible with job safety and employee health.

(c) Contractor management bas the reaponsibility to establista procedures to ensurs that all employees with occupational injuries or ithesses rective witten clearance from the occupational modical department before being permitted to rehum to work. 


\section{REQUIREMENTS IDENTIFICATION DOCUMENT HIGH LEVEL WASTE STORAGE TANK FARMS Occupational Safety and Health}

(d) The responsible irstline management and health and safety groups (bealth physics, industriat hygiene, or safexy) shall be given notification of unhealthy work sibrations detected by the occupational medical staff."

\section{FACILITY REQUIREMENT SOURCE: DOE5490.8A Section 11.e(2)}

"Nonoccupational Injury and Illness. Employees shall be encouraged to utilize the services of 2 private physician of medical facility, where these are available, for care of nonoccupational injuries or illnesses. However, the medical department shafl assist employees who become ill at work. Care should be available for what any be judged a short-term, self-timited eondition. Such * policy will contributs to containment of widitel costs ind encourage an atmospitere of trust for euployes. The objective is to retwra the worker to a stete of heslif in the shortest possitile time consistent with modesn medical therapy. Logg-term treatment of nonoccupational injury and illesss is not considered to be a routine responsibility of an cocupational medieal program. NOTE: In emergencies, employees stall be given the aecessery care requined until referred to a private physician or facility."

\section{FACILITY REQUIREMENT SOURCE: DOE5480.8A Section 11.c(3)}

"Manitored Care. Monitored care of ill or injured employes by occupational medical physicians is highly desirable to maximize recovery and safe retum to work and to minimize lost time and sssociated costs. Contractor management bes the responsibility to advise the occupational anedical department when an employee has been absent because of an illness or injury for more than 5 consecutive workdays, or has experienced excessivo absentesism. Worker's compensation cases should be montiored when appropriate througb frequent retum visits and physician-to-physician communication with private physicians where applicable. The goal is to assist the employees in their recovery and to tacilitste their retura to duty at the eartiest practicable time. Reasonable accommodations or restrictions may be a part of this rebabilitation process and need to be elosely coordinated with the heman resources department and lipe manggennent."

\section{FACILTY REQUIREMENT SOURCE: DOE5480.9 Section 6.a(1)(a)}

"(I) A dessriptive cutline of the contractor's program encompassing industrial safety, beslth protection, and fire prevention and protection aspects. The program should be appropriate to the size of the project and associated hazands, and shell inelude, but not bo limited to:

(a) Adequate provisions for emergency aid such se trained medical aid porsonnel and treatront facilities, and adequate fire protection during all phases of construction."

\section{Fitness for Dutr}

This stbelernent addresses the requirements for establisting and maintaining an effective Fitness for Duty Progran. A properly implemented intess for 


\section{REQUIREMENTS IDENTIFICATION DOCUMENT HIGH LEVEL WASTE STORAGE TANK FARMS Occupational Safety and Health}

duty progran provides assurance of a drug and alcohol free workplace and that tomployees aro able to perform their assigned tasks.

The Ocenputional Henlth Program defines fitmess for duty requirements and develops fitness for duty procedures. The Polictes and Procedires section of the Management Systems Functional Aves outlines the controls for development, use, and mainiexance of fitress for duty policy and prosedures. The Safoguards and Security Program intertaces with local law enforcement concerning fituess for duty issues.

\section{FACILITY REQUIREMENT SOURCE: DOE\$480.\$A Section I1,d(3)}

(3) Fitness for Continued Duty Assigumeat. The ocoupational medical department bas the responsibility to make fituess-for-duty determinations on employees for all conditions that rmay unfuence performance or work sujtrability.

(a) A substance abuse (diug and alcohoi) identification and rehabilitation progran is an integral pert of a comprebensive fimess-for-duty program. Any testing provided shall be in accordance with accoptable prictices and applicable regulations. The goal is to promote a safe and healthy work environment and to rehabilitate employees involved with sabstance abuse.

(b) Employees shall be evaluated for the presence of medical conditions that any be ressonably expected to impair employes's safe, reliable, and trustivorthy performence of assigned tasks and, thereby, affect the acceptatiolity of an enploye for \& specific job assignment.

(c) Occupational medical personnel sball consider the job duties of any employes seking medical care to determine if the heolth condition is job related. In addition, an evaluation should be made of the employee's fitness-to-perform job duties sefely and reliably."

\section{FACIITY REQUYREMENT SOURCE: EEI Chapter II, Section 1}

A clear definitive policy statement on drug and alcobol abuse as a part of a tocal fitmess for duty program, stroagly supported by top management, should be established. The policy should be writted and clearly state the tesponsibitities of management and employes relative to a fitnes for duty progran, including the consequences which may result from lack of adherence to suxh a policy.

\section{FACILITY REQUIREMENT SOURCE: EET Chapter II, Section 3}

The methods used to commumicate the fitaess for duty polioy should be establisbed. This section diseusse elaments that ghould be considered when planning bow the policy will be communicoted. 


\section{REQUIREMENTS IDENTIFICATION DOCUMENT HIGH LEVEL WASTE STORAGE TANK FARMS Occupational Safety and Health}

\section{FACILITY REQUMREMENT SOURCE: EEI Chapter H, Section 7}

Contractors and visitors should be advised that they mist abide by the rules established by the fitness for duty program. Clear notification should be piven thet this is 2 condition of access to the site/factity and equipment. This section destibes methods for notifying contrattors/visitors of fitness for duty regulations.

\section{FACח.TTY REQUIREMIENT SOURCE: EEI Chapter II, Setion 8}

Local law enforeament officials should be routinely notified upon the diseovery of suspected illegal substances. Federal law probibits the possession, sale or use of controlled substances except by qualified individuals. Any violations of this law must be reported to the proper authorities.

\section{Medicnl_Eacilities and Equipment}

Oecupational medical aetivities require adequate facilities and equipment to effectively perform their designated function.

The Engineering Desigu Functiongl Area addresses the design criterin for medical faciltties. The Occupational Medical Program shall provide the Decassary information to the Engineering Design Organization to ensure that medien facility design requitements afe sufficient for optrationai needs (both existing and future).

\section{FACICTY REQUIREMENT SOURCE: DOE/EHOL35 MS.1.5}

"5. Adequate resources are provided to support the medital services nieeded for the facility and site."

\section{FACILITY REQUIREMENT SOURCE: DOE/EH0135 MS.3.3}

" 3. The medical fecilitios and the medical equipment aeeded to support the site and facility, both onsite and offsite, are adequate.

\section{FACILITY REQUIREMENT SOURCE: DOE/EH0135 MS.3.4}

4. Transportation facilities for medical emorgencies are adequate."

FACULTY REQUIREMENT SOURCE: DOR 5480.8 A Section 11.h(1)

-Occupational Medical Facilities. Geotral design criteria for tocupational medicad facilities are contained in DOE 6430.1A. Specifically, these facilities:

(8) Shatl be located in areas readity accessible to employees and to transportation. Accessibility of the occupationed medieal department is a key 


\section{REQUTREMENTS IDENTIFICATION DOCUMENT HIGH LEVEL WASTE STORAGE TANK FARMS Occupational Safety and Health}

factor in employee utilization of medieal services and is very important to the overall effectiveness of the program.

(b) Stuall be sufficiently spacions, well lighted, and ventilsted with appropriate climate control.

(c) Shall include waiting, consultation, examining and amergency treatment areas, wilet, and shower or tub fecilities adexuate to ensure privacy and comfort.

(d) Shall bave necessary moditial and Jaboratory equipment with adequate decontertination facitties.

(e) Sball include 2 rest or recovery room, dressiug rooun, and facilities for the laboratory and radiological examinations performed in the department.

(f) Shall include ambulance services and equipment that meet appilicable State or Federal regulations. It is not necessary to assign responsibility for ambulance and rescane personul, operations, and explpment to the Site Decupptiogal Medjeal Director.

(g) Shall have access to medical information through a library and/or computerized information systems.

(b) Dispensing, storing and disposing of phermaceuticats shall be in eccordance with appropriate Federal, Stote and tocal law.

\section{FACITY REQUIREMENT SOURCE: DOE5480.8A Section 11.h(2)}

\section{"Equipment.}

(a) The Site Occupational Medical Director shall ensure that the medical department equipment is adequate in torms of present-day accepted standards of medical practice and that it is maintsined in good working order and is properily calibrated.

(b) The selection of specific kinds end brands of medical office and laboratory equipment shalt be determined by the Site Ocempational Medical Director. Preference should be guven to devices that cen provide direct input to compoterized data

systems. The following minitumm items sbould bo inciuded:

1 Standard distant and pear visual actity eye charts or optical testers;

2 Standard color vision plates (Istihan, Dvorine, or Amerien Optical);

3 Audiometer with a testing booth which moets OSHA standasis; 


\section{REQURREMENTS IDENTIFICATION DOCUMENT HIGH LEVEL WASTE STORAGE TANK FARMS Occupational Safety and Health}

4 Electrocardiograph equjpment;

5 Pulmonary function equipment;

6 Cartiac defibrillation and relatid monitoring equipment adequate for portable use;

7 Suction equipment:

8 Pulmonary resusejtation equipment;

9 Adequate equipment for monitoring, handling, and decontamination of radioactively contaminated or chemically contamtinated testualies;

10 Pbysiotberapy equipment as nodedi and

11 Emergency power supply."

FACILITY REQUIREMENT SOURCE: DOE6430.1A Section 0110-99.7

"01 10-99.7 Decupational Health Facilities

0110-99.7.1 General

In the planning of a new Occupationai Health Facility, the estimated case load stall be developed in collaboration with the facility operating group. In addition, the availsbie nearby community medical facilities skall be considered and the requifentents of DOE 5480.8 shalt be followed.

Where ratiological hazards are a factor and an adequare comounicy facility is not available, provisions shall also be made far eaturgency minor surgical, decontamination, and lifesaving medical care for casualties or injutries resulting from radioactive contamination.

The size and location of the facility shall depend on:

o The number and aeeds of employes to be served

- Exteot of treatment and other activities inclucied within the scope of the occupational bealth program

o The nomber of doctors and purses required in accordence with DOE 5480.8

0 Reasonably anticipated expansioo

o The distance from hazardous operations

o The radiological conditions to be encountered 
WHC-EP-6750

\title{
REQUIREMENTS IDENTIFICATION DOCUMENT HIGH LEVEL WASTE STORAGE TANK FARMS Occupational Safety and Health
}

\author{
0110-99.7.2 Location
}

The location of the Oceupotional Health Facility in an immediate plant area will be influenced by the following factors:

o Notse leval of nearby piant components

- Accessibility of the main occupational health facility to the greatest aumber of employees. Under certain conditions, a location oear the msin entrance to the plant to treilitate examination of ampioyment applicants may bo advantageous.

- Auxiliary Facilities. It may be occessary to place dispensaries or first aid field stations as auxiliary moditol umits in ontlying or bazardous arens. These stations may occupy space in butldings provided primarily for otber functions.

0110-99.7.3 Space Requirements

Spaco shall be provided to fulfill the current and foreseeable feoture requirements for the following functions:

- Pbysicat examinations, including preplacement, peciodic, and termination examinations

- Dingnosis and pertinent treatment for imunodiate relief of injured and sick employees

o Proveptive care and coruaseling, jmmunizations, and beslth education"

\section{Professional Development of Occupational Staff}

The Occupational Medical Program shall also facilitate the continued professional development of the mexical staff; including definition of available training courses, seoninass, conferences, laboratory experience, field sudy, and ather learning activities which would assist the occupational medical specialist in the performante of bis/are duty.

The Occupational Medical Program shall provide the Training Program with the information and support required to effectivedy institute the necessary medieal/fitness for duty training.

\section{FACILITY REQUIREMENT SOURCE: DOE/EH0135 MS.1.4}

- 4. Medical staff are properly trained and participate in continuing edsecation and skitl-development programs." 
wíc-EP-B750

\title{
REQUIREMENTS IDENTIFICATION DOCUMENT HIGH LEVEL WASTE STORAGE TANK FARMS Occupational Safety and Health
}

\author{
FACILITY REQUIREMENT SOURCE: DOES480.8A Section 11.g(1)(e)
}

"Should bavo opportumities for continutiog medical eduction, attendance at national oceupationel medical metings (including DOE-sponsored meetings and health seminars), and access to wedical joumals. The physikian should also be sfforded the opportunity for mernbership in professional organizations.

\section{FACILTY REQUREMENT SOURCE: DOE5480.8A Section 11.g(2)(c)}

"Should have opportunities for continuing medical education, attendance at national oesupational modical meetings (including DOE-sponsored meetings and health seminars), and acesss to medical jelraals. They should also be aftorded the opporthunily for membership in professional organizations as approved by the Site Occupational Medienl Director."

\section{FACIIITY REQUTREMENT SOURCE: DOES480.8A Section 11.g(3)(c)}

"Should be afforderi opportunities for continuing nursing education, including attendance at professional meetings, and access to nursing journals as approved by the Site Mediteal Director. Thay should tlso be afforited the opportunity for mambership in professional organizations as approved by the Sike Occupational Medical Director."

\section{FACILITY REQUIREMENT SOURCE: DOR5480.8A Section I1.g(4)(c)}

"Should be afforded opporanities, as deterutined by the Site Medical Dixector, for continuing psychologieal education related to services provided on the site, including use of psychological evaluation. Psychologists employed fultime shall be afforded opportunities for membership and partictipation in professional associations."

\section{FACILITY REQUIREMENT SOURCE: DOE\$480.8A Section 11.g(5)(c)}

"Counselors employed fulltime should be afforded opportunities for continuing echucation, membership, and participation in professional associations as approved by the Site Oectupational Medical Director."

\section{FACILITY REQUTREMENT SOURCE: DOE5480.8A Section 11.g(6)(c)}

"Should be afforded opportunities for coptinuing medical education, incluxting attendance at professional meetings and access to medical joumbis, as well as organizational memberships as determined by the Site Occupational Medical Director." .

\section{PACIITY REQUIREMENT SOURCE: DOE5480.8A Section 11.g(7)(c)}

"Should be afforded opportunitios for contimuing medical education, inclusing attendance at professional meetings and access to joumals, as weil as ongarizational memiterships as determined by the Sito Occupational Medieal 


\section{REQUIREMENTS IDENTIFICATION DOCUMENT HIGH LEVEL WASTE STORAGE TANK FARMS Occupational Safety and Health}

Dirsector:-

\section{FACILITY REQUIREMENT SOURCE: EEI Chapter I, Section 4}

Supervisors should be given clear responsibility for behavioral observation of their employes and should be given special tratinition to ensure they bave the knowtedge and ability to perforen that task well. Suptrisors ane in day-to-day contact with their personnel and aro most familiar with thair nortal bebavior patterens. Therefort, they are in the best position to detect changes in employess' behavior and to initiate appropriate corrective action in aceordane with the fitoss for duty propram.

\section{Emergency Planning}

This sub-itement specifics the requirements for the Occupational Medical Program to develop and implement the medical response portion of the applituble emergency/disaster preparedness plans. The medical portion of the emergency and disastar respoose capability shall be idequate to meet the type and severity of accidents and trantria dictuted by the cherracter and history of plant operations and conditions.

The Emergency Proparectness Functional Aree contains the controls which govern the development, use, and maintenance of the emergency/disaster plans. The Decipational Medical Program provides the oecessery medieal information and support for these plans.

\section{FACILITY REQULREMENT SOURCE: S4FR3904 Part (c)(3)(iv)}

"Establish a medical program which includes availability of first aid on site and of physician and emergency mexical care cearby, so that barm witl be minimized if an injory or illness does occur."

FACILITY REQUIREMENT SOURCE: WAC-296-24 Seetion 060(I)

'In addition to RCW 51.36.030, every employar shall comply with the department's requirements for first-aid tratning and cortification."

\section{FACILIY REQUREMENT SOURCE: WAC-296-24 Section 060(2)}

"There shall be present ox available at all times, a person or persons holding a valid certificate of first-aid training. (A valid first-aid certificente is one which is less than three years old.)"

\section{Heaith_Records_and Reporting}

This sub-tentent addresses the reaguirements for establithing a medical record documentation and control systern Specifically, the programmatic controis necessary to initiate, maintain, update, distribute, rotrieve, and refile medical records shatl be clearly defined. The tontrols necessery for collecting and reporting occupstional injury and illiness dita shall also be 


\section{REQUIREMENTS IDENTIFICATION DOCUMENT \\ HIGH LEVEL WASTE STORAGE TANK FARMS \\ Occupational Safety and Health}

clearly defined.

The Docuranat Control/Records Management section of the Management Systems Functional Area contain the coptrols aecosery to establish a Medical Record system within the Occopational Metical Program.

\section{FACIITY REQUIREMENT SOURCE: 29CFR1910 Part 120(0)(8)(0)}

"Recordkeeping. An aceurate record of the medieal surveillance required by paragraph (f) of this section shail be retained. This record shall be retained for the period specified and neet the criteria of 29 CFR 1910.20."

\section{FACILITY REQUIREMENT SOURCE: 29CFR1910 Part 120(t)(8)(it)}

"Medicat surveitlance. The resord regaired in paragraph (f)(8)(i) of this section stall inctude at least the following information:

(A) The name end social security number of the employse; (B) Pbysician's written opinions, recommended limitations, and results of examinations ant trists;

(C) Any employee metical complatints related to exposure to hazardous substances; (D) A copy of the information provided to the examining physician by the employer, with the exception of the standard and its appeodices."

\section{FACLITY REQUTEMENT SOURCE: DOEVEHO135 MS.2.3}

3. A system for modical servites reporting is documented and implemented."

FACILITY REQUIREMENT SOURCE; DOE3790.1A Chapter VII, Section 4.h(7)(a)

"Maintains records of accupational jlinesses in accordance with the recondkepping requirements of the Act."

FACILITY REQULRMENT SOURCE: DOE3790.1A Chapter VI, Section 4.b(7)(b)

"Consults with the industrial bygiente staff in the development of adequate methods to detect exposurs to harmful edvironmental agents in the context of periodic physicals or biogssays."

\section{FACILITY REQULREMENT SOURCE: DOE3790.1A Chapter VII, Section 4.b(7)(c)}

"Alerts the industrial bygiene staft to all suspected occupational iltnesses to facilitate early ovaluations and corrections of problens."

FACIITY REQUIREMENT SOURCE; DOE3790.1A Chapter VI, Section $4, b(7)(d)$

-Alerts the industrial hypiente staft to all diagmosed pecupational illnesses for foltowup investigations. These followups shall be designed to supply the information required by the Oceupational Safety and Health Administration (OSHA) Form No. 200F, "Record or Log of Federal Oxcupational Injuries and 


\section{REQUIREMENTS IDENTIFICATION DOCUMENT HIGH LEVEL WASTE STORAGE TANK FARMS Occupational Safety and Health}

Ilnesses," or its equivalent."

FACIITY REQUIREMENT SOARCE: DOE3790.1A Chapter VII, Section S.n

"Reporting Requiremeots.

(1) Heads of Fiedd Organizations, the designated Hedquarters offictial, or designees, shall be advised of the results of each health ovaluation performed on one of their employees which contains meaningful data relative to physical linutations and/or work restrictions in order to ensurt salt: placement of the empioyee.

(2) A monthly summary of the types of treatments performed by the health services staff shall be submitted to the safety and health official of each field organtzation or Headquarters as approptiate."

FACILITY REQUIREMENT SOURCE: DOE3790.1A Chapter VIH, Section 5.0

"Medical Records.

(1) Field Organizations shall maintain records of employee medical exarninations in accordance with instructions of the Office of Personnel Mamagentent in the Federal Personned Mantol, chapter 339; DOE 1700.1; and DOE $1800.1 \mathrm{~A}$.

(2) Medical records and professional evaluations of curreat enoloyees and persons selected for appointront will be maintained under the control of bealth service personnel and for use only by professional persomel, industrial hygientists, and health physicists.

\section{FACILITY REQUIREMENT SOURCE: DOE5480.8A Section 11.e}

"Req̨uitements for Medical Records.

(1) Records Maintenance. The majptenance of complete medical reconts developed by the medical departinent for ench enployes from the time of the first examination or trestment is a basic requirement. A personal health record shall be maintained for each employee identifying nama, date of birth, and social security number. The contrator may use adoitionsl jdentification systerns as desired.

(2) Confidentiality.

(a) The confidentiality of all employed medical reconds, including the resuls of health examinations, shall be observed by all members of the occtupational medical steff. Such records shall remrin in the exclusive custody and control of the occupationat medical department. Disclosure of information from an employee's health records shall nox be made without written consent, except 29 perminted by law or Federal regulation.

(b) Computerized or microfilmed medicd records 2nd information shall remain under the custody and controi 


\section{REQUIREMENTS IDENTTFICATION DOCUMENT HIGH LEVEL WASTE STORAGE TANK FARMS Occupational Safety and Health}

of the Site Occuparioual Medical Director with disclosure as defined in paragraph lie(2)(a) above.

(3) Access to Employee Medical Records. Access to employee medical records shall be in aceorinuce witb: (2) The Privacy Aat as coditied in 10 CFR 1008.17(b)(1); ard (b) "Aceess to Exposure and Medical Records" as codified in 29 CFR 1910.20 (OSHA Smadard).

(4) Identification of Medical Records. It shall be the responsibility of contenctor utaulagement to provide the Site Ocelppational Medical Director with information to anable the coding or thegging of records to reflect current job titles, specinic job certifications or limitations, assigned work ateas, and work bazands.

(5) Work Restriction Registry. The Medical Director will advise contractor management of appropriate work restrictions. Contractor management sbould maintain a centrai work restriction registry.

(6) Retention of Medieal Records. All enoployee bealth records shall be retained in accordance with DOE I324.2A. However, inactive records may be retired to kow-cost storape in an onsite records holding area or a Federal Records Center. To protect the confidentiality of the records, the shipping cartons shatl bo sealed and the transfer doctments shall note that access to the recorda is limited to personnes of the Contractor Meitical Department. If resources are avaikable, the files may be microfilmed and the paper records destroyed.

\section{SITE REQUIREMENT SOURCE: DOE5494.1 Chapter IV, Section 3.c}

-Report of Radiation Expostures ta Headquarters Employeso. Report all recorded extertal and internal radiation exposures that oceur during a visit by Department of Energy Headquartars employese to a field edement of contractor facility. Complete appropriate portions of DOE F 5484.8, and subarit it to the System Safoty Dovelopment Center (SSDC), EG\&G Idabo, Inc., witbin 30 days after the individuais's date of visit or within 30 doys after his or ber exposure has been detormined, whichever is later."

\section{STTE REQUIREMENT SOURCE: WAC-296-62 Section 05207(1)(a)}

"Employee medical records. The medieal record for each employes shall be preserved and maintained for at least the duration of employment plus thirty years, except that the following types of records geed not be retained for any specific period:

(i) Health insurance ciaims recorts maintained separately from the employer's medical program and its recoords:

(ii) First-aid records (not imcluding modical histories) of ont-time treatment and subsequent observation of minor scratches, cuts, burns, spitinters, and the like which do not involve medieal treatment, loss of 


\section{REQUIREMENTS IDENTIFICATION DOCUMENT HIGH LEVEL WASTE STORAGE TANK FARMS Occupational Safety and Health}

consciousness, restriction of work or motion, or trausfer to another job, if cands on-sile by a anpbysictian and if maintained separately from the employer's medical program and its records; and

(iii) The medical reconds of exployees who have worked for less than one year for the employer need not be retained beyond the term of employment if they are provided to the empioyee upan the termination of empioyment."

\section{Medieal Stafing}

This sub-element addresses the requirements for organizing and staffing an Occupational Medieal Program. The responsibitities and accountabilities of the Medical staff and managenent/employeess sball be cleariy defined and cominutricated. The Occurpational Medieal Program interfaces with onsite organizations and programs shall be clearly defined.

The Policies and Procedures section of the Management Systems Functional Area contains the necessary controls for preparing organizational charts.

\section{PACIIITY REQUIREMENT SOURCE: DOE/EH0135 MS.1.1}

- 1. Lipe menagemeat assures adequate medical services are available and adequate to provide needed medical services."

\section{FACILITY REQUIREMENT SOURCE: DOEJEH0135 MS.1.2}

-2. Site mediel staff has a direct line of communication with top Ixiraigement. Reports and recommendations of the medical steff ate not subjected to inappropriate managerrent by non-medical staff."

\section{FACILITY REQUIREMENT SOURCE: DOE/EH0135 MS.1.3}

3. Appropriate arrangements and agreentents are mide with off-site providers of medical support."

\section{FACILITY REQUTEMENT SOURCE: DOEJEHO135 MS.1.6}

6. Monigement estoblishes specific gools and objectives for minimizing the demands on medieal services by reducing ivjuries and illossses."

\section{FACILITY REQUIREMENT SOURCE: DOEEHO135 MS.2.I}

1. Procedure provide direction to asstre medical services are uniformly and adequately ingtemented."

\section{FACILITY REQUIREMENT SOURCE: DOE/EH0135 MS.2.2}

2. Written policies identify the responsibilities and autborities for cosite and offstite medical staff for providing medical services." 
WHC-PP-6750

\section{REOURRMIENTS IDENTIFICATION DOCUMENT HIGH LEVEL WASTE STORAGE TANK FARMS Occupational Safety and Health}

\section{FACILITY REQUTREMENT SOURCE: DOE/EHOI35 MS.3.1}

"1. The types of medical strvices needed to sipport facility and site operations are identified."

\section{FACILITY REQUIREMENT SOURCE: DOE/EH0135 MS.3.2}

2. The medical shaff noeded to support the site and facility are aveilable and trined."

\section{FACILITY REQUIREMENT SOURCE: DOE/EसO135 MS.4.t}

"1. Medical poilicies are audited regularly and when there are major changes in the site or freility activities or the availability of supporting medical organizations that could require modifications to the medical services program."

\section{FACILITY REQUIREMENT SOURCE: DOEJEH0135 MS.5.1}

1. Medical hazards in the workplace are communicated to employess and visitors to the site/facility."

\section{FACILITY REQULREMENT SOURCE: DOEJEH0135 MS.5.2}

"2. Employees are provided written notification of monitoring results when an employes's exposure txceeds permissibie limits."

\section{FACIITY REQUIREMENT SOURCE; DOE/EH0135 MS.5.3}

3. Employees are informed of their tights and responsibilities and the employer and DOE resources available to resoive concerns on potential health hazarde in the work exvironment."

\section{FACIITY REQUTREMENT SOURCE: DOE3790.1A Chapter VII, Seetion 5.a}

"Health Services Persongel.

(1) Health services shail be provided unter the direction of a licensed physician, and nursing services shal] bo provided by licensed professional nurses. To the maximutn extent feasible, such physicians and ourses stall be qualified in coctupational medicine and occupational nursing.

(2) As an alteraative, Heads of Field Organizations may elect to contract for mediesl services. When this option is selected, licensed physictans and ourses shall be qualified in oocupational medicine and occupationat oursing, if possible, and programs shall comply with the requirements of this chapter."

\section{FACILITY REQUIREMENT SOURCE: DOE5480.10 Section 9.a(2)}

"The Medical Orgenization should be required to: (a) maintain records of occlupational ilipesses in aceordunce with the recordkeeping requirements of Title 29 CFR 1904; (b) consult with the industrial hygient staff on the need 


\section{REQUIREMENTS IDENTIFICATION DOCUMENT HIGH LEVEL WASTE STORAGE TANK FARMS Occupational Safety and Fealth}

for job-rtateted matical exarminations or bionssays; (c) alert the industrial by giente stoff to all suspected ocetupational illoesses to fecilitote early evalustions and correction of problems; and (d) include the industrial hygiente staff, if appropriate, in the investigations of oceupational illeseses."

\section{FACILITY REQUIREMIENT SOURCE: DOE5480.10 Section 9.b(6)}

"Medical Monitoring. The industrial hygiepe stafr shall inform the medical organization of potential and existing bealth bazards identified, the resuits of hazand evaluations, and other industrial bygiene information needed for operation of a medical monitoring program. The industrial hygiene staff should be available to aceompany medical stoff on periodic worksite visits (vefor to DOE \$480.8))."

\section{FACILITY REQUIREMENT SOURCE: DOE5480.8A Section 10.a}

-Implementation of an ansite cocupational medicat progiam shall be the responsibitity of the Site Occupational Medical Director. The occupational medical director for each comtractor site shall develop a written ocetpational medical plan detailing the methods and procedunes used to implement the minimom requirentents of this Order which are set ous in parzegraph 11."

\section{FACHITY REQUOREMENT SOURCE: DOE5480.8A Section 11.a(1)}

"Occupational physicians and selected medical staft shall make regular visits to worksites and [aciltites so 28 to become farniliar with employee job tasks, worksite environments, and existing or potential bealth hazands. Such visits should be coordinated with industrial bygiene, health physics, and safety personntl and management, and should inclodo a review of materials, processes, and procedures used with emphasis on physical, chemical, and biotogical fatards. The information obtained from these visits may form the basis for recommendations to management for corrective action or preventive measures. The frequency of worksite visits should be determined by the Site Oceupational Medical Director, taking into actougt such factors as the size of the workfores, and the nurnter and types of operations. Othor factors stould intluds the nature and amounts of physical, chemical, or biological agents ussed; the accident and incident rate; and the occupational illness and disability rate. Appropriate medical staff should conduct familiarization visits at selected worksites at least monthly."

FACILITY REQUIREMENT SOURCE: DOR3480.8A Section 11.a(2)

'Contractor managentent shall furoish the Site Occupational Medical Director with information on potential, physical, chemical, and biological hazards in the worksite.

\section{FACLITY REQUIREMENT SOURCE: DOES480.8A Şection 11.a(3)}

-Prior to the performance of a periodic health exarnination, the contractor management shall provids to the OHE a summary of potential exposures to 


\section{REQUTREMENTS IDENTHICATION DOCUMENT HIGH LEVEL WASTE STORAGE TANK FARMS Occupational Safety and Health}

hrzardous ageats or taiks and any worksite exposares in excess of OSHAVOE permissib]e expossare timits pertaining to the employeses to be examined."

\section{FACILITY REQUIREMENT SOURCE: DOE5480.8A Section 11.a(4)}

"Contractor management should afford the Site Occupational Medical Director or desi joee the opportunity to participate in new materials and process review committes, safery comrnittees, and other bealth-related meetings."

\section{FACIITY REQUTREMENT SOURCE: DOE5480.8A Section 11.g(1)(b)}

"Stall report directiy to the Contractor Sito Manager, approptiats Laboratory Director, or another managerdent level with stfficient authority to ensure program effectiverass."

FACILITY REQUIREMENT SOURCE: DOE5480.8A Section 11.g(1)(c)

-Shall participate in health and Environontental issues at the policy-uraking levels."

FACILTY REQUIREMENT SOURCE: DOE5480.8A Section 11.g(1)(d)

"Shall be responsible for the development, interpretation, implementation, and administration of the occupational medical programe"

FACILITY REQUIREMENT SOURCE: DOE5480.8A Section 11.g(2)(b)

Shall be directly resposastble to the Site Occupational Mfedical Director or designes."

FACILTTY REQUIREMENT SOURCE: DOE\$480.8A Section 11.g(3)(b)

-Shall be directly responsible to the Site Oxcupational Medical Director or designee."

FACILITY REQUIREMENT SOURCE: DOE5480.8A Section 11.g(4)(b)

"Shal] be directly responsible to the Site Occupational Medical Director or designee."

FACILITY REQUIREMENT SOURCE: DOE5480.8A Section 11.g(5)(b)

"Shall be responsible to the Sito Oceupational Medied Director or designee."

FACILITY REQUIREMENT SOURCE: DOE5480.8A Section 11.g(6)(b)

"Shall bo responsibie to, and work under, the stupervision of the Site

Occupational Medical Director or desigues. 
WHC-EP-0750

\section{REQUIREMENTS IDENTIFICATION DOCUMENT \\ HIGH LEVEL WASTE STORAGE TANK FARMS \\ Occupational Safety and Health}

FACILITY REQUIREMENT SOURCE: DOES480.8A Section 11.g(7)(b)

"Shall be responsible to the Site Oecupational Medical Director or designee.

FACIITY REQUIREMENT SOURCE: DOES490.SA Section 11.g(8)(b)

"Shall be responsible to the Site Decupational Medical Director or designee."

FACILITY REQUIREMENT SOURCE: DOE5430.8A Section 11.g(9)

"(9) Professional Stafing.

(a) General. The proper ratio of physicians and nurses to the employee population is related to many factors, including the following:

1 Size of employee population;

2 Geographical distribution and location of enployees;

3 Shitts worked;

4 Rate of exploye nirpover,

$S$ Age and sex distribution of the employes population;

6 Extent of occupational bazards and associated medical surveillance requirements;

7 Types and complexities of job tasks and operations performed;

8 Total number of ail health examinations required;

9 Degree of isolation of worksites from community and other nodical services; and

10 Degree of employe utilization of occupational health services.

(b) Minimum Physicien Staffing. For sittes with employes populations greater than 2,500, the Medical Durector shatt not be incloded in meetug the physician stoffing requirement.

1 At least 1 part-time physician for employee populations between 300 and 1,000 ;

2 Ope fatk-time physician for employe populations over 1,000 and under 1,500 ;

3 One full-time and 1 balf-time physicians for employee populations over 1,500 but under 2,000;

4 Two full-time and 1 balf-tinte physicians for employee 


\section{REQUIREMENTS IDENTIFICATION DOCUMENT FIGH LEVEL WASTE STORAGE TANK FARMS Occupational Safety and Health}

populations over 2,000 but under 2,500; and

5 An additional physician for exch additional increase of 1,000 to 1,500 employees.

(c) Minimum Nurse \$tafing.

1 One part-lime nutse for up to 100 employecs;

2 One full-time nurse for employee populations over 100 and up to 300 ;

3 Two till-time aurses for enployes populations over 300 and up to 1,000 ;

4 Three fitllime purses for the first 1,000 emaployees;

5 One additional full-time nurse for exch additional

1,000 employees up to 5,000; and

6 One additiontal foll-time nurse for exch additional 2,000 employees over 5,000 .

(d) Minimur Requirements for Worksites not Covered by a Physician or Nurse. At worksites with expoloyez populations not wartanting a foll-time nurse or pbysician (i.e., less than 100 employees), ranageroent shall enosure at least one employes on duty is trained and currently qualified in first aid and cardiopulowonary resuscítation.

(e) Ancillary Staffing. The mumber and qualifications of physician assistants, murse practitioners, and other ancillary medical personsel shall be determined by the Site Occupational Medieal Direetor as required to support the occupational medical progerm. Utilization of these personuel may partially offiset the prescribed stafling levels of physicians and aurses.

(9) Psychological Stafifing. The Site Occupational Medical Director shall establisb consulting relationships with psychiatrists or psychologists as required by the demands of the program. At sites with 2,000 or more employees, $\mathfrak{l}$ full-time equivalent clinical psychologist and/or psychintrist is suggested. The option of contricling for the services of a part-time clinical psychologist or psychiatrist for facilities with fewes than 2,000 employess or to stoplenent existing services is acceptable."

\section{FACUITY REQUIREMENT SOURCE: EEI Chapter II, Section 1}

A clear definitive policy statement on dug and afcahol abouse as a part of a total fitaess for duty program, strongly supported by top management, should be established. The policy should be written and clearly stato the responsibilitios of mangsentent and enployees relative to a fitmess for duty program, including the consequeoces which may result from lack of adberence to such a policy. 
WHC-EP-07SO

\section{REQUREMENTS IDENTIFICATION DOCUMENT HIGH LEVEL WASTE STORAGE TANK FARMS Occupational Safety and Health}

\section{FACILITY REQUIREMENT SOURCE: EEI Chapter I, Section 2}

The effectiveness of a fitoess for duty progrem will depend upon the degres of deminstrated involvement and support from seatior management The established fitoess for duty policy should be clearly communiterted to employees by monagement. All violations of the establisked policy skould be tofored both faitly and impartially by managearent.

This element outlines the need for beath and safery training to proveot persomel exposute to and control of known physical, biolopical and chemical hazards. In addition, the documentation of OSH training and the maintenknce of those records is discussed.

\section{FACIITTY REQURREMENT SOURCE: DOE3790.1A Chapter VIII, Section 5.k}

Emergency Training. Employees shall bave the opportunity to receive training in the basic elements of first aid and cardiopulmonary resuscitation (CPR) and CPR refrester training, at no cost to the employee.-

This sub-element addresses the requirements which ensure that general employees, managers/supervisors, and visitors/contractors are propedy trained with regard to appropriate bealth and safely, medied and fimess for duty requirtments. The OSH Program stall also facilitate the continued professional development of the health and safety staff; inslnding definition of available training courses, serrinars, conferences, laboratory experience, field stuxdy, and other learning activities which woyld assist the OSH specialist in the performance of his/her duty.

\section{FACILITY REQUIREMENT SOURCE: 29CFR1910 Part 120(c)(8)}

"Enployes notification. Any information concerning the cherrical physical, and toxicologit properties of each sulsstance known or expected to be present on site that is available to the employer ind retevant to the duties an employec is expected to perform shatl be made available to the affected employees prior to the commencement of their work activities. The employer may utilize information developed for the hazad communication standard for this purpose."

\section{FACLTTY REQUIREMENT SOURCE: 29CFR1910 Part 120(e)(1)(i)}

"Employees shall not be permitted to gartisipate in or supervise field activities until they bave been trained to a level requirad by their job function and responstibility."

\section{FACILITY REQUREMENT SOURCE: 29CFR1910 Part 120(e)(2)}

"Elements to be covered. The trainiug shall thoroughly cover the followng:

(i) Names of personnel and altezuates responsible for site safety and health;

(ii) Saiety, bealth and otber hazards present on the site;

(iii) use of persosal protective equipmost; 


\section{REQUIREMENTS IDENTIFICATION DOCUMENT HIGH LEVEL WASTE STORAGE TANK FARMS

\author{
Occupational Safety and Health
}

(iv) Work practices by whitb the employe can minimize risks from bazards;

(v) Safe use of engineering controls and equipment on the sits;

(vi) Medical surveillante requireareats, including recognition of syurptoms and signs which might indicate overexpostro to bropids; and

(vii) The contents of paragraphs (O) through (J) of the site safery and health plan set forth in parsegroph (b)(4)(ii) of this section."

\section{FACILITY REQUIREMENT SOURCE: 29CFR1910 Part 120(e)(3)(i)}

"Initial training. General site workers (such as equipment eperators, general laborers and suparvisory personnel) engaged in hazardous substance removal or other activities which expose or potentially expose workers to hazardous substances and bealth hazards stall receive a mintonum of 40 hours of instruction off the site, and a minimum of three days arnual field experience under the direct supervision of a trained, experienced supervisor."

\section{FACIITY REQUIREMENT SOURCE: 29CFR1910 Part 120(e)(3)(ii)}

Tnitial teaining.

Workars on site oaly ocessionally for a specific limited mak (such as, but not limited to, pround water monitoring. land surveying, or geo-physical surveying) and who are unlikely to be exposed over perrusssible exposure limits ant publisbed exposure limits shall receive a misimum of $\mathbf{2 4}$ hours of insinuction off the site, and the minimum of one day actur field experitence under the diract supgrvision of a trained, experienced suptrvisor."

\section{FACIITY REQUTREMENT SOURCE: 29CFR1910 Part 120(e)(3)(iii)}

"Initial training. Workers regutarly on site who work in areas which bave been monitored and fully characterized indicating that exposures are under permissible exposure limits and published exposure limits where respirators are aot necessary, and the cheracterization indicates that there are no bealth hazords or the possibility of an emergency developing, shatl receive 2 minimum of $\mathbf{2 4}$ hours of instruction off the site and the minimum of ope day actital field experience under the direct supervision of a trained, experiented supervisor."

\section{FACILITY REQUTREMENT SOURCE: 29CFR1910 Part 120(e)(3)(iv)}

Tnitial training Workers with 24 hours of trining who are covered by parzerzphs (e)(3)(ii) and (e)(3)(iii) of this section, and who become general site workers or who are required to wear respirstors, sha|] beve the additional 16 bours and two days of training vecessary to total the training specified in paragraph (o)(3)(0)."

\section{FACILITY REQULREMENT SOURCE: 29CFR1910 Part 120(e)(4)}

"Management and supervisor teaning. On-site management and supervisors ditectly [esponsible for, or who supervise enployees engaged in, hazardous wasto operations shall receive 40 hours initial training, and three days of supervised field experienoe (the training may be refuced to 24 hours and one day if the only area of their responsibility is employees covered by paragraphs (e)(3)(ii) and (e)(3)(jii) and at least eight additional bours of specialized training at the time of job assigmments on such topics as, but not limited to, the employer's safety and heath program and the associated employe training program, personal protective 
WHC-EP-0750

\section{REQUIREMENTS IDENTIFICATION DOCUMENT HIGH LEVEL WASTE STORAGE TANK FARMS Occupational Safety and Health}

equipment program, spill containment program, and bealth hazard mooitoring procedure and vechniques."

\section{FACULTY REQUIREMENT SOURCE: 29CFRI910 Part 120(e)(S)}

-Qualifications for trainers. Trainers shall be qualified to instruct employees dbout the subject matter that is being presented in training. Such trainers shall have satisfactorily completed a training program for tenching the sabjects tbey are expected to tesch, or they siall bave the atadesuic credentials and instructional axperience necessary for teaching tie subjects. Instructors shall dermonstrate competent instructional skills and knowledge of the applicable subject watter."

\section{FACILITY REQUIREMENT SOURCE: 29CFR1910 Part 120(e)(6)}

"Training certification. Employees and supervisors that have teceived and successfully completed the tratining and field experience spectified in parajgaphs (e)(1) throalgh (e)(4) of this section stall be cerdified by theit instructor or the heod instrustor and trained supervisor as baving successfulty completed the necessary training. A written certificate stall be given to each person so certified. Any person who has not beed so certified or who does not meet the requirements of paragraph (e)(9) of this section sball be probibited frou engaging in hazardous waste operations,"

\section{FACIIITY REQUTREMENT SOURCE: 29CFR1910 Part 120(e)(7)}

"Training.

Einergency response. Employees who are exgaged in responding to bazandous emergeacy situations at bazardons waste ciesp-up sites that way expose them to hazardous artostances shall be trained in bow to respond to such expected emergencies."

\section{FACILITY REQUIREMENT SOURCE: 29CkR1910 Part 120)(e)(8)}

"Refresher trajning. Employees specified in paragraph (e)(1) of this section, and managers and supervisors specifext in para'fiph (e)(4) of this section, shall receive eight hours of refiesher training ampally on the items specified in parzgraph $(e)(2)$ and/or (e)(4) of this section, any critique of incidents that bave oceurred in the past year that can serve as training examples of related work, and other relevent topics."

\section{FACIIITY REQUIREMENT SOURCE: 29CFR1910 Part 120(e)(9)}

'Equivalent training. Emplayers who can show by documentation or certification that an employee's work experitence and/or training bas resulted in training equivalent to that training required in paragraphs (e)(b) through (e)(4) of this section shall got be required to provide the initial treining requirements of those paragraphs to such employess and stall provide a copy of the certification or docurpeptation to the enployee upon request. However, certified employess or enployees with equivalent training new to a sito shalt recefve appropriate, site specific training before site entry and have appropriate sugervised field experience at the new site. Equivalent training includes any academic training of the training that axisting estaployees might bave already recejved from actual hazardous waste site work experience." 
WTC-EP-0750

\section{REQUIREMENTS IDENTIFICATION DOCUMENT HIGH LEVEL WASTE STORAGE TANK FARMS Occupational Safety and Heaith}

\section{FACILITY REQUIREMENT SOURCE: 29CFR1910 Part 120(1)}

"Informational programs. Employers shall develop and implemeat a paogram, which is part of the entoloyer's safety and heslth program required in paragraph (b) of this section, to inform tomployees, contractors, aud subcoctrentors (or their tapresentative) actually eagiged in bazardous waste operations of the nature, leved anil degree of expossure likely as a result of perticipation in such bazardous wasto operations. Employees, contractors and subcontractors working outside of the operations part of a site are not covered by this standard."

\section{FACALTY REQUIREMENT SOURCE: 29CFR1910 Part 147 (c)(7)(i)}

\section{Tockout and Tagout}

The employer shall provide training to ensure that the purpose and function of the exergy control progtam are understood by employees and that the knowledge and skills required for the safe applicstion, usage, and removal of the energy controis are aequired by employees. the training shall inclute the following: (A) Each authorized employee shall receive training in the recognition of appilicable hazandous energy sources, the type and maguinide of the ectergy avajlable in the workplese, and the methods and means necessary for entercy istiation and control. (B) Sach affected employes shalt be instructed in the purpose and use of the energy control procedurs. (C) All other suployes whose work operations are or may be in an arsa whers energy control procedures may be utilized, shall be instructed about the procedurt, and about the prohibtition releting to atternpts to restart or reenergize machines or equipment which are locked out or tagged out."

\section{FACILITY REOUIREMENT SOURCE: 29CFR1910 Part 147 (c)(7)(ii)}

Lockout and Tagout

(i) When thgout systems are used, employees still 2lso be trined in the following limitations of tags: (A) Tags are essentially waming devices affixed to edergy isolating devices, and do not provide the physical resirain on those devices that is provided by a lock. (B) When a tag is attached to an energy isolating means, it is not to be removed without authorization of the authorized person responsible for it, and it is nover to be by passed, igaored, or othenwise . deferated. (C) Tags must be legible and understandable by all authorized employees, affected employees, and all other employees whose work operations are or may be in the area, in order to be effective. (D) Tags and their means of atteciment mast be mode of moterials which will withstend the ectironmental conditions cocountered in the workplace. (E) Tags may evoke a false sense of securtity, and their meaning needs to bo understood as part of the overall enerty control program. (F) Tags must be sectrrely attached to onergy isolating devices so that they cannot inadvertently or accidentally detached during use."

\section{FACIL,ITY REQUIRFMIFNT SOURCE: 29CFR1910 Part 147 (c)(7)(iii)}

\section{"Lackout and Tagout \\ Employee retraining (A) Relraining shall be provided for all authorized and affected entoployees whenever there is a change in their job assiguments, a change in machines, equipmeat or proceses that present a new brzard, or whed thene is a change in the energy control procedures. (B) Additional retraining shall also be conducted whonever a periodje inspection under paragraph (c)(6) of this section revesls, or whenever the exployer has reason to believe, that there are deviations from or inadequncies in the employes's knowledge or use of the energy cootrol procedures. (C) The retraining shall restablish atmptoyes proficiency and introduce new or revised control methods and procedures, as necessary.}




\section{REQUIREMENTS IDENTIFICATION DOCUMENT FIGH LEVEL WASTE STORAGE TANK FARMS \\ Occupational Safety and Health}

\section{FACILITY REQUREMENT SOURCE: 29CFR1910 Part 332 (b)(3)}

Trining

(3) Additional requirements for qualified petsons. Qualified persons (i.t., those permitted to work on or ner exposed entrized parts) sball, at a minimum, be trained in and formitier with the following(i)The sills and tectmiques necestry to distinguish exposed live parts from other parts of electric equipment, (ii) The skills and techniçues nocessary to deterntine the cominal voltage of exposed live parta, and (iit) The clearence distances specisied in 29 CFR 1910.333 (c) and the corresponding voltages to which the qualified person will be exposed. Note I: for the purpose of 29 CFR 1910.331 through 1910.335, a person must have the training requited by paragraph (b)(3) of this section in onder to be considered a qualified person. Note 2: Qualified persons whose work on energized equipinent involves eitoter witset contact by means of tooks or materials must be also bave the training neaded to meet 29 CFR $1910.333(\mathrm{c})(2) \cdot{ }^{*}$

\section{FACILITY REQUIREMENT SOURCE: 54ER3904 Part (c)(4)(i)}

"Ensure that all employes undesstand the bazards to which they may be exposed and bow to prevent harm to themselves and otbers from exposure to these hazards, so that edrpiloyees acoept and follow whteltished safety and bealth protections."

\section{FACLITY REQUREMENT SOURCE: 54FR3904 Part (c)(4)(ii)}

"So that suptervisors will cerry out theit safery and health rosponsibilities effectively, ensure that they understand those responsibilities and the reasons for them, including (A) Amalyzing the work under their sapervision to ideutify unrecognized potential tazards! (B) Maintaining physical protections in their work areas; and (C) Reinforcing employes training on the nature of potential hazards in thoir work and on needed protective measures, through sontinual performanee feedback and, if necessary, through enforcement of safe work prextices."

\section{FACILITY REQUIREMENT SOURCE: S4FR3904 Part (c)(4)(ii)}

"Ensure that roanagers undorstand their stefety and health responsibilities, as described under (c)(I), "Management Commitment and Employeo Involvempents" so that the managers will effectively carry out those reponsibilities."

\section{FACILITX REQUIREMENT SOURCE: 54FR3904 Part 3904.(b)(4)}

"Stfety and bealth training addresses the safety and hesth responsibilities of all personnel coocerned with the site, whether salaried or hourly. It is often most effective when incomporated into other training about performance requirentepts and job practices. It complexity depends on the size and conpiexity of the worksite, and the uanze of the hazands and potential tratards at the site." 
WHC-EP+0750

\section{REQUIREMENTS IDENTIFICATION DOCUMENT HIGH LEVEL WASTE STORAGE TANK FARMS Oecupational Safety and Health}

\section{FACILITY REQUIREMENT SOURCE: DOE/EH0135 OS.3.5}

"5. Proper occupational safety equipueat is anilabile, its use is enforced, and proper training for its use is provided."

\section{FACILITY REQUREMENT SOURCE: DOE/AH0135 PP.1.3}

3. The staff is responsible for the direction and operation of personntk protection programs are professionaily qualified and bave sufficient time and authority to iropiement the established program."

\section{FACILITY REQUTREMONT SOURCE: DOE5480.10 Section 9.a(4)}

"Fiest-line Suparvisots should be required to: (a) maintain healthful working conditions withio his or her own organization and implement industrial bygiens recommendations; (b) train eoployes to perform assigaments in a safe manner; and (c) follow administrative procedures to allow appropriato disciplinary action to be taken when health and safety nules are violated."

\section{FACILITY REQUIREMENT SOURCE: DOES480.10 Section 9.b(5)}

"Exployee Education. The industrial hygiene steff shall assist the first lovel supervisor in the developonent of en employes information and training progrem whenever a potential bealth hazard exists requiring engineering controls, administrative procedures, or persooal protectjve equipment. The program shall include written notification of employees of environmental monitoring results when the results indicate that the enployees are exposed above permissible limits. Training should include information on operations that may lead to exposure, the potential health effects of the bazard, the content of applicsble standards, and the purpose and resalts of environtmentol montitoring."

\section{STTE REQUIREMENT SOURCE: DOE5480.20 Chapter I, Section 7,e(1)}

a. General Emoployee Traioing (GET) Requirearents.

(1) All persons employed either full- or pert-time in DOE reactor and gon-reactor muclear facilities shall be trained in the following areas commenstrate with their job dutíes:
(a) General description of facilities;
(b) Job related policies, procedures, and instructions;
(c) Radiological bealth and safety program;
(d) Facility emergency plans;
(e) Industrial safacy/hygiene program; 
WTC-EP-0750

\section{REQUTREMENTS IDENTIFICATION DOCUMENT HIGH LEVEL WASTE STORAGE TANK FARMS Occupational Safety and Health}

(i) Fire protection program;

(g) Security program; and

(h) Quality assurance program.

\section{STTE REQUIREMENT SOURCE: DOE5480.20 Chapter I, Section 7.e(2)}

-Visitors, contracted personnel, and temporary personnel shall be under continuous escort while at the facility nnless they have been trained in appropriate areas from the above tist to the exted decsary to engsure safe execption of their duties. For example, short-term visitors should be given instruction in items (a), (c), (d), (e), and (g), while contracted and temporarily assigned persoanel may need training in additionsal topics as related to their assignments."

\section{FACILITY REQUREMENT SOURCE: EEI Chapter II, Section 4}

Supervisors should be given clear responsibility for behavioral observation of their employees ind should be givea specisl trairing to ensure they bave the knowledge and ability to perform that task well. Supervisors are in day-to-day contact with their personenti and ars most familtar with their norutal behavior patterns. Therefore, they are in the best position to detect changes in employes" behavior and to initiate appropriane correctivo aetion in accordance with the fitmess for duty program.

\section{FACILITY REQUIREMENT SOURCE: EEI Chapter II, Section 5}

Supervisors should be provided with specific guidelines apd training as to what to do if an individual employes appears to be unfit for duty of appears to have druge or alcobol in his possession. This section illustrates the type of guidrnce that aupervisors should be given.

FACILITY REQUIREMENT SOURCE: WAC-296-24 Section 020(1)(c)

Trutining prograns to improve the skilf and competency of all entoloyees in tho field of cocupalional sofery and health. Such training shall inclute the on-the-job instructions on the safe use of powered materials handling equipment, macbine tool operations, use of toxic materials and operation of utility systems prior to assigerments to jobs involving suck exposares."

\section{HAZWOPER Troining}

This sub, sub-element contains the requirements for content of the Hazardous Waste Operations and Eroergency Response Training Programs (HAZWOPER). 


\title{
REQURREMENTS IDENTIFICATION DOCUMENT HIGH LEVEL WASTE STORAGE TANK FARMS Occupational Safety and Health
}

\author{
FACIITY REQUIREMENT SOURCE: 29CFR1910 Part 120(b)(4)(ii)(B)
}

The site safecy and health plan, as a minimum stall address the following; Eroployee training assignments to assure compiringes with paragriph (e) of this section."

\section{FACILTY REQUIREMENT SOURCE: 29CFR1910 Part 120(c)(8)}

"Empioyee notification. Any information conceraing the chemical physical, and toxicologic properties of each substance known or expected to be present on site that is available to the enployer and relevint to the dutios su exployee is expected to perform stioll be ando svallable to the affected employees prior to the commencement of their work activities. The employes may utilize information developed for the bazand commurication standard for this purpose."

\section{FACILITY REQUIREMENT SOURCE: 29CFR1910 Part 120(e)(1)(1)}

\section{Trining.}

Geperal. All empitoyees working on site (such as but not limited to equipuent operators, general laborers and others) exposed to bazardotus substances, bealth bazards, or sofety hazards and their suppervisors and management responsibite for the site sholl receive training meeting the reauirements of this paragraph before they are permitted to engage in hazardous waste operations that coutd expose them to bazardous stubstances, safety, or bealth bazarcs, and they shall receive reviow tratining as specified in this paragraph."

\section{FACILITY REQUIREMENT SOURCE: 29CFR1910 Part 120(e)(1)(ii)}

"Employes shall not be perritted to participate in or supervise field activities until they have been trinined to a level required by their job function and responsibitity."

\section{FACILTY REQUIREMENT SOURCE: 29CFR1910 Part 120(e)(2)}

"Elements to be covered. The traiging shall thoroughly cover the following:

(i) Names of personnej and alternates responstble for site safery and healthi

(ii) Safity, health and other hazards present on the site;

(ii) use of personal protective equipment;

(iv) Work practices by which the employee can minimize risks from hazards;

(v) Safe use of eagineering controls and equipment on the site;

(vi) Medical surveitlance requirements, including recognition of symptoms and signs which might indicate overexposure to hazards; and

(vii) The contents of paragraphs (G) through (J) of the site ssifty and bealth plan set forth in paragraph (b)(4)(ii) of this section."

\section{FACILITY REQUIREMENT SOURCE: 29CFR1910 Part 120(e)(3)(i)}

"Iritial training, General site workers (such as equipment operators, general laborers and supervisory personnel) engaged in hazardous substance removal or obber activities which expose or potiotially expose workers to hazardous substances and health hazards stall recive a minimum of 40 hours of instruction off the site, and a minimum of three days achual held experience under the direct supervision of a trained, experienced supervisor." 
WhC-EP-0750

\section{REQUIREMENTS IDENTIFICATION DOCUMENT HIGH LEVEU WASTE STORAGE TANK FARMS Occupational Safety and Health}

\section{FACLITY REQUIREMENT SOURCE: 29CFRI910 Part 120(e)(3)(ii)}

"Initial training.

Workers on site only oceasionally for a specific limited task (such as, but not limited to, ground water monitoring, land surveying, or geopphysteal surveying) and who are unlikely to be exposed over permissiblo expostre limits aud publisted exposure linits shail recsive a ruinimum of 24 hours of instruction off the site, ind the minimam of one day actunl field experientice under the direct supervision of a tritued, experienced supervisor."

\section{FACILITY REQUIREMENT SOURCE: 29CFR1910 Part 120(e)(3)(iti)}

"Initial training. Workers regularly on site who work in areas which have been monitored and fully characterized indicating that exposures are under permissibie exposure limits and publisbed exposure límits where respirators are not necessary, and the characterization indicates that there are no heilth bazards or the possibility of an ecuergency developing, stosll receive a minimum of $\mathbf{2 4}$ hours of instruction off the site end the minimum of one day actual field experience tinder the direct supervision of a traibed, experienced supervisor."

\section{FACILITY REQUIREMENT SOURCE: 29CFR1910 ParE I20(e)(3)(Iv)}

"Initial trainiog Workers with 24 bours of training who are covered by paragraphs (e)(3)(ii) and (e)(3)(iii) of this section, and who become general site workers or who ate sequited to wear respirators, shail have the additional 16 hours and two days of training necessary to total the training specified in paragraph (e)(3)(i)."

\section{FACILITY REQUTREMENT SOURCE: 29CFR1910 Part 120(e)(4)}

"Maragement and supervisor trating. On-site management and stupervisors directly responsible for, or who supervise enployees engaged in, bazardous waste operations shal receive 40 hours initial training, and three days of supervised field experience (the training may be reduced to 24 hours and one day if the only area of their responsibitity is amployess covered by paragraphs (o)(3)(ii) and (o)(3)(iii) and at least eight additronal hours of specialized training at the time of job assignments on such topics as, but not limited to, the employer's safery and healti program and the associated employee training program, persanal protective equipment program, spill containnent program, and health bazard monitoring procedure and vectmiques."

\section{FACILITY REQUIREMENT SOURCE: 29CFR1910 Part 120(e)(5)}

"Qualifications for trainers. Trainers shall be qualified to instruct employees about the subject matter that is being presented in training. Stret trituers shall bave satisfactorily completed a training progras for teaching the subjects they are expected to teach, or they shall have the academic credentiais and instnuctional experience necessary for teaching the subjects. Instructors stall demonstrate competent instructional skills and krowledge of the applicable subject matter."

\section{FACILITY REQUIREMENT SOURCE: 29CFR1910 Part 120(e)(6)}

"Training certification. Employees and supervisors that bave received and successfully completed the training and field experience specified in paragraphs $(e)(1)$ through (e)(4) of this 
WHC-EPATSO

\section{REQUIREMENTS IDENTIFICATION DOCUMENT HIGH LEVEL WASTE STORAGE TANK FARMS Occupational Safoty and Health}

section stall be certified by their instruetor or the head instructor and trained supervisor as baving stocesssfully completed the recessary training. A written certificate shell be given to exch person so certified. Any person who bas not beed so certified or who does not meet the requirements of paragraph (o)(9) of this section shall be probibited from engaging in hazandous waste operations."

\section{FACILITY REQUIREMENT SOURCE: 29CFR1910 Part 120(e)(7)}

"Training.

Errergency response. Employees who are engaged in respotding to hazardous emergency situations at hazandous waste clean-up sites that may axpose them to bazardous substances shal? be trained in how to respond to such expected emergencies."

\section{FACILITY REQUREMENT SOURCE:-29CFR1910 Part 120(e)(8)}

"Refrestrer training. Enpployees specified in paragraph (e)(1) of this section, and managers and supervisors specifed in paragraph (e)(4) of this section, shall receive eight bours of refresher training amentlly on the itens spexifiest in paragraph (e)(2) and/or (e)(4) of this stection, any critique of incidents that have occured in the past year that can serve is tratining examples of related work, and otber relevant topics. "

\section{FACILITY REQUTREMENT SOURCE: 29CFR1910 Part 120(e)(9)}

"Equivalent training. Employers who can show by documentation or certification that an employee's work experience and/or training has resulted in training equivalent to that training required in paragraphs (e)(1) through (e)(4) of this section shall not be required to provide the initial training requirements of those paragrapis to such employees and shalt provide a copy of the certification or documentation to the employee spon request. However, certined employees or enployess with equivalent training new to a site shall receive sppropriate, site specific training before site entry and have appropriate supervised field experience at the new site. Equivalent training iscludes any academic training or the training that existing employees might bave already received from actial hazardous waste site work expertence."

\section{FACILITY REQCIREMENT SOURCE: 29CFR1910 Part 120(i)}

"Inforthational programs. Employers shall develop and implement a program, which is part of the employer's safery and health program required in paragreph (b) of this section, to inform employees, contractors, and subcontractors (or their representative) actually engaged in hazardows waste operations of the nature, leved and degre of exposure tikaty as a result of participation in such bazardous waste operations. Employees, contractors and subcontractors working outside of the operations part of a site are not covered by this standard.

\section{SFTE REQUREMENT SOURCE: WAC-296-62 Section 05207(1)(a)}

"Employee medical records. The medical record for each employee shall be preserved and maintained for at least the duration of employment ples thirty years, except that the following rypes of records need abt be retsined for any specifte periot:

(i) Healtb insurance etains records maintained separately from the 


\section{REQUTREMENTS IDENTIFICATION DOCUMENT HIGH LEVEL WASTE STORAGE TANK FARMS \\ Occupational Safety ard Health}

employer's medical program and its records;

(ii) First-aid records (not including medical histories) of ono-tims treatment and subsequent abservation of minor seratches, cats, burns, splinters, and the like which do oot involve medical treatment, loss of conscionaness, restriction of work or motion, of transfer to another job, if made onesite by 2 nonphysicion and if maintained separately from the employer's medical program and its records; and

(iii) The medical necords of employecs who have worked for less than one year for the employer ated not be reteined beyond the tera of enoloyment if they are provided to the employee upon the termination of amployment."

FACIIITY REQUIREMENT SOURCE: WAC-296-62 Section 3040 (6)(a)(i)

"Overview of the applicetste section of Part P of chapter 296-52 WAC and the elemeals of an employer's effective oceupotional safety and health program. "

\section{FACILITY REQUIREMENT SOURCE: WAC-296-62 Section 3040 (6)(a)(ii)}

"Effect of chemical exposure to hazardous subetances (i.e., toxicity, carcinogees, imitants, sensitizens, etc.)"

FACILITY REQUIREMENT SOURCE: WAC-296-62 Section 3040 (6)(a)(iti)

"Effects of biological and radiological exposures."

FACILITY REQUIRENENT SOURCE: WAC-296-62 Section 3040 (6)(a)(iv)

"Fire and explosion hazands (i,e, flammable and combustibie liquids, reactive materials)."

FACILITY REQUIREMENT SOURCE: WAC-296-62 Section 3040 (6)(a)(ix)

"Use of personal protective eqtipment and the implemenution of the personal protective equipment program."

\section{FACILITY REQUTREMENT SOURCE: WAC-296-62 Section 3040 (O)(a)(v)}

"Genecal safexy hazards, including olectrical hazarck, powered equipment hazards. walking-working surface hazards and those bazands associated with bot and cold temperature extremes-

\section{FACUITY REQUIREMENT SOURCE: WAC-296-62 Section 3040 (6)(a)(vi)}

"Confined spice, tank and vazlt hazards and eotry procedures."

\section{FACILITY REQUIREMENT SOURCE: WAC-296-62 Section 3040 (6)(a)(vif)}

"Names of personne] and altemates, where appropriate, responsitue for site safety and bealth at the site." 
WHC-EP-OTSO

\section{REQUTREMENTS IDENTIFICATION DOCUMENT \\ HIGH LEVEL WASTE STORAGE TANK FARMS \\ Occupational Safety and Health}

FACIITY REQUIREMENT SOURCE: WAC-296-62 Section 3040 (6)(a)(viii)

"Specific safety, health, and other bazands that are to be addressed at a site and in the site safety and bealth plan."

\section{FACIIITY REQUIREMENT SOURCE: WAC-296-62 Section 3040 (0)(a)(x)}

"Wok practices that will minimize employee risk from site hazards."

FACILITY REQUIREMIENT SOURCE: WAC-296-62 Section 3040 (0)(a)(xi)

"Safe use of engineering controls and equipment and my new relevant technology or procedure."

FACILITY REQUIREMENT SOURCE: WAC-296-62 Section 3049 (6)(a)(xii)

"Conteat of the medical surveillance program end requirements, includiog the recognition of stgus and syouptoms of overexpasure to hazardous substacess."

FACILITY REQUIREMENT SOURCE: WAC-296-62 Section 3040 (6)(a)(xii)

The contents of an effoctive site safety and bealtb plan."

FACILITY REQUIREMENT SOURCE: WAC-296-62 Section 3040 (6)(a)(xiv)

Use of monitoring equipment with "hendsen" experience and the iuplementation of the employes and site monitoring program."

FACILIY REQUTREMENT SOURCE: WAC-296-62 Section 3040 (6)(a)(xix)

-Methods for handting shock-sensitive wastes."

FACILTY REQUDREMENT SOURCE: WAC-296-62 Section 3040 (0)(a)(xv)

"Impiementation and use of the information program."

FACIITY REQUTREMENT SOURCE: WAC-296-62 Section 3040 (6)(a)(xvi)

"Drim and sontainer handling procedures and the elements of a spith containment program."

FACILITY REQUIREMENT SOURCE: WAC-296-62, Section 3040 (0)(a)(xvi)

"Selection and use of moterial handling equiputent."

FACILITY REQUIREMENT SOURCE: WAC-296-62 Section 3040 (6)(a)(xtii)

"Methods for assessinent of risk and handling of radionctive wastes." 
WRC-EP-0750

\section{REQUIREMENTS IDENTIFICATION DOCUMENT HIGI LEVEL WASTE STORAGE TANK FARMS \\ Occupational Safety and Health}

FACILTY REQUIREMENT SOURCE: WAC-296-62 Section 3040 (6)(a)(xx)

"Laboratory waste pack handling procedures."

FACILIY REQUIREMENT SOURCE: WAC-296-62 Section 3040 (6)(a)(xri)

"Contziner sampling procedures and safeguards."

FACXITY REQUTREMENT SOURCE: WAC-296-62 Section 3040 (6)(a)(xxil)

"Safe prepartition procedures for shipping and transport of containers."

FACUITY REQUIREMENT SOURCE: WAC-296-62 Section 3040 (6)(a)(xxii)

"Decontamination program and procedures."

FACILITY REQUIREMENT SOURCE: WAC-296-62 Section 3040 (0)(a)(xoiv)

"Emergency response plap and procedures includimg first aid."

FACILITY REQUIREMENT SOURCE: WAC-296-62 Section 3040 (6)(a)(xxix)

"Sources of reference, additional information and efficient use of relevagt manuals and bazard couding systems."

FACIIITY REQUIREMENT SOURCE: WAC-296-62 Section 3040 (0)(a)(xxy)

"Safe site illumination kevels."

FACILITY REQUIREMENT SOURCE: WAC-296-62 Sectian 3040 (6)(a)(xXv)

"Site sanitation procedures and equipment for employee neds."

FACILITY REQUIREMENT SOURCE: WAC-296-62 Section 3040 (6)(a)(xxyii)

"Reviow of the applicable appendices to Rart P of chapter 296-62 WAC."

FACILITY REQUIREMENT SOURCE: WAC-296-62 Section 3040 (6)(a)(xxviji)

"Overview and explanation of WISHA's hazard communication standard Part $\mathrm{C}$ of chapter 296-62 WAC."

FACILITY REQUIREMENT SOURCE: WAC-296-62 Section 3040 (6)(a)(xxx)

"Principles of toxicology and biological monitoring."

FACILTY REQUIREMENT SOURCE: WAC-296-62 Section 3040 (6)(a)(xxxi)

"Righss and responsibilities of empioyes and employers under WISHA and CERCLA." 
WHC-EP-0750

\section{REQUIREMENTS IDENTIFICATION DOCUMENT \\ HUGH LEVEL WASTE STORAGE TANK FARMS \\ Occupational Safety and Health}

FACLITY REQUIREMENT SOURCE: WAC-296-62 Section 3040 (6)(a)(xxxii)

"Hands-on" field exexcises and demonstrations."

FACILITY REQUIREMENT SOURCE: WAC-296\%62 Section 3040 (6)(b)(b)

"Overview of applicable sections of Part P of chapter 296-52 WAC and the elements of the employes's effective oceupational safaty and beaith program."

FACILITY REQUIREMENT SOURCE: WAC-296-62 Section 3040 (0)(b)(ii)

"Employes rights and rosponsibilities under WISHA and CERCLA."

FACILITY REQUIREMENT SOURCE: WAC-296-62 Section 3040 (6)(b)(tii)

-Overview of relevant cherrical exposures to hazardous substances (i.e., toxics, carcínogeos, itritants, sensitizers, etc.)."

FACILITY REQUIREMENT SOURCE: WAC-296-62 Section 3040 (6)(b)(tv)

"Overview of the pripciples of toxicology and biological monitoring."

FACILI'Y REQUTREMIENT SOURCE: WAC-296-62 Section 3040 (0)(b)(1x)

"Watk practices that will minimize employee risk from site hazards."

FACIIITY REQUTREMENT SOURCE: WAC-296-62 Section 3040 (0)(b)(v)

"Use of monitoring equipment witb hands-on proctice and an overview of a site monitoring program."

FACIIFY REQUIREMENT SOURCE: WAC-296-62 Section 3040 (6)(b)(vi)

"Overview of stite hazaris trelusding fire and explosion, confined spaces, oxypen defieiency, electrical hazards, powered equiponent hazards, walking-working surface hazards."

FACILTTY REQUIREMENT SOURCE: WAC-296-62 Section 3040 (6)(b)(vii)

"The contents of an effective site saffety and health plan."

FACLITY REQUIREMENT SOURCE: WAC-296-62 Section 3040 (6)(i)(viit)

-Uste of personal protective equipment and the implementrition of the personal protective equipment progrim."

FACILITY REQUTREMENT SOURCE: WAC-296-62 Section 3040 (6)(b)(x)

"Site sinulations with "hands-on" exercises and practice." 
whe-pa-0750

\section{REQUIREMENTS IDENTIFICATION DOCUMENT HIGH LEVEL WASTE STORAGE TANK FARMS Occupational Safety and Health}

FACILIY REQUREMENT SOURCE: WAC-296-62 Section 3040 (6)(b)(xi)

"Emergency respornse plankiug and response including first aid."

FACILITY REQUIRENENT SOURCE: WAC-296-62 Section 3040 (0)(b)(x+l)

"Content of the medieal surveillance program and requirements, including the recognitios of signs and symptams of overexposture to hazardous substances."

FACILITY REQUIREMENT SOURCE: WAC-296-62 Section 3040 (6)(b)(xiii)

"Decontamination programs and procectures."

FACILITY REQUIREMENT SOURCE: WAC-296-62 Section 3040 (G)(b)(xiv)

"Safe use of engineering controls and equipmeat."

FACIITY REQUIREMENT SOURCE: WAC-296-62 Section 3040 (6)(b)(xv)

"Soutces of references and efficient use of relevant minumls and knowiedge of bazard coding systerns."

FACIITY REQUIREMENT SOURCE: WAC-296-62 Section 3B40 (6)(c)(i)

"Relevant chemical exposures to hazardous substances beyond that previously covered."

FACIIIY REQUIREMENT SOURCE: WAC-296-62 Section 3040 (6)(c)(ii)

-Site hezards including fire and explosion, confined spaces, oxygen deficiency, electrical, powered equipanent, and walking-working surfaces beyond that previously covered."

FACILITY REQUIREMENT SOURCE: WAC-296-62 Section 3040 (6)(c)(ii)

"Nomes of personmel and alternates responsible for site safety and health at the site, where appropriate."

FACIITY REQUIREMENT SOURCE; WAC-296-62 Section 3040 (6)(c)(iv)

"Use of monitoring equiprnent and the impledrentation of the employee and the site monitoring prograta beyond that proviously covered."

FACILITY REQUIREMENT SOURCE: WAC-296-62 Section 3040 (6)(c)(ix)

"Methods for handling shock-sensitive wastes."

FACILITY REQUIREMENT SOURCE: WAC-296-62 Section 3040 (o)(c)(v)

"Implementation and use of the informational program." 
wic-np-07sto

\section{REQUIREMENTS IDENTIFICATION DOCUMENT HIGH LEVEL WASTE STORAGE TANK FARMS Occupational Safety and Health}

FACIITY REQUIREMENT SOURCE: WAC-296-62 Section 3040 (G)(c)(vi)

"Drum and contriner banding procedures and the elements of a spill contrinment program."

FACILITY REQUIREMENT SOURCE: WAC-296-62 Section 3040 (6)(c)(vii)

"Selection and use of material hanfling equipment."

FACIIIY REQUIREMENT SOURCE: WAC-296-62 Section 3040 (6)(c)(vii)

"Methods for assessment of rist and handling of radioactive wastes."

FACILITY REQUIREMENT SOURCE: WAC-296-62 Section 3040 (6)(c)(x)

"I,aboratory waste pack handling procedures."

FACILTYY REQUIREMENT SOURCE: WAC-296-62 Section 3040 (6)(c)(xi)

"Containtor sampling procedures and safegtards."

FACLITY REQUIREMENT SOURCE: WAC-296-62 Section 3040 (6)(c)(xii)

"Sefe preparation procedures for shipping and transport of containers."

FACILITY REQUIREMENT SOURCE: WAC-296-62 Section 3040 (0)(c)(xiij)

"Decontemenation program and procedures."

FACILITY REQUIREMENT SOURCE: WAC-296-62 Section 3040 (0)(c)(xiv)

"Safety site illumination levels."

FACILITY REQUIREMENT SOURCE: WAC-296-62 Section 3046 (0)(c)(xv)

"Site sanitation procedures and equipment."

FACILITY REQUIREMENT SOURCE: WAC-296-62 Section 3040 (6)(c)(xvi)

"Review of the applicable appendices to Part P of chapter 296-62 WAC."

FACIIITY REQUIREMENT SOURCE: WAC-296-62 Section 3040 (6)(c)(xrit)

-Overview and explaglation of WISHA's Hazard Communication Standard Part C of ctropter 296-62 WAC.-

FACILITY REQUIREMENT SOURCE: WAC-296-62 Section 3040 (6)(c)(xriti)

"Sources of reference and additional information." 


\title{
REQUIREMENTS IDENTIFICATION DOCUMENT HIGH LEVEL WASTE STORAGE TANK FARMS \\ Occupational Safety and Health
}

\author{
FACILITY REQUIREMENT SOURCE: WAC-296-62 Section 3040 (6)(c), \\ Introduction
}

-16-hour supplemental training for bazardous trasta sites. As a minimum, empioyess who have recefved 24 hours of tratning for hazardous waste site operations stall receive training in the following topies before they are allowed to work as general sito workers of if they are reguired to wase respirators: ${ }^{*}$

FACILITY REQUITEMENT SOURCE: WAC-296-62 Section 3040 (6)(d)(0)

"Managemens of bazardous wastes and their dispossl."

FACHITY REQUIREMENT SOURCE; WAC-296-62 Section 3040 (6)(d)(i)

"Federal, state, and local agencies to be contacted in the event of a release of hazardous substances."

FACILIY REQUTREMENT SOURCE: WAC-296-62 Section 3040 (b)(d)(tit)

"Management of omergency procedures in the event of a rejease of bazardous substances."

FACULIY REQUIREMENT SOLRCE: WAC-296-62 Section 3040 (6)(d), Introduction

"Additional 8 bours of training for supervisors and mantigers. Suptrvisors and managers shall receive an additional eight hours of training in the following subjects:

\section{OS\&H Trainint, Resordkeeping, and Reporting}

This sub-lentent details the proper maintenance of training records and co-site reporting of training. Thiz requirements tor these functions are completely addressed within the Trining Functional Axea.

\section{FACILITY REQUTREMENT SOURCE: 29CFR1910 Part 147 (c)(7)(iv)}

\section{"Lockout and Tagout}

The control of hazardous energy (lockout/lagout)

(iv) The employer shall certify that employee trining bas been accomplished and is being kept up to date. The certification shal] contrin exch mployes's anme and dates of training,"

\section{RECORDKEEPING AND REPORTING}

This elensent relates to the controls necessary for record genteration, record storage, record retention, and enployee record aceessibjility constratnts.

\subsubsection{QSizH_Record Mantagentent and Exposure Renorting}

This sub-elerrent establistes the OSH Record Management and Exposure Reporting 


\section{REQUIREMENTS IDENTIFICATION DOCUMENT HIGH LEVEL WASTE STORAGE TANK FARMS Occupational Safety and Health}

System. The controts tecessary for an effective record management program are completely addressed within the Management Systems Functional Ares. The requiremeats for Exposure Reporting are detailed in this sub-lement.

\section{FACILTY REQUIREMENT SOURCE: DOE5489.10 Section 9.f(4)}

\section{"Records shall be roteined in accortance with DOE 1324.2, RECORDS DISPOSITION." FACILITY REQUIREMENT SOURCE: DOE5483.1A Chapter I, Section 5.d}

-All contractor employees stall be informed that the contractor is required to monitor the employes's workplace for ratiation exposure and known toxic materials or harmfol physical agents which are used or produced at the GOCO facility, and to maintain reconds of the data as required by Title 29 CFR Part 1910.20, "Aceess to Employee Exposure and Medical Records." Employees or their antborized represeotatives are to bo provided with an opportunity to observe monitoring or meastring for toxic materials and barmful physical agents and to bave access to the results thereof. Exch employee or former empioyee or representotive thereof, within 15 days of a written request, shati be provided access to or copies of any recorts of cumbulative recorded occupstional rediation dose or any monitoring or biosssy recortis relevant to potatial exposure to toxje materials or bsrmful physical agents duriog employment. Erroployeses will be notified of any information indicating that a radiation dose or an exposure to toxic materials or barmfui physical agents may bave exceeded the limits specified by the DOE-prescribed OSHA standards."

Oecurrence Reporting

This sub-elentent addresses the requirements for reporting, notification, estegorization, implementstion, roviow, and follow-up of oceurrences. These requirements are completely addressed with the Managerpent Systems Functional Area.

\section{Orcupational Iniury and IHness Reparting}

This sub-eiement details the requirements for reporting of all oceupational injuries and ilnesses, These controls ine[ude methods for, recording/maintaining medical and toxic expostres for the duration of a workers employment and/or lifetime as required; and posting injury ard ilness data amuaily as required by OSHA regulatious.

\section{FACILITY REQUREMENT SOURCE: DOE/EHO135 PP.1.5}

"5. Necessary information is readily communicated to top management, to al1 segments of the organization copcemed, and to the public and regulatory agencies, appropriate"

\section{KEY PROGRAM INTERFACES}

The intritementation and actministration of an Occupational Health and Safety Program requirts the definition of interfaces with ober functional areas. All Tank Farm Facility activities are governed by the sitewide Occupacional Health and Safey Program. Specific 
WHC-ER-0750

\section{REQUIREMENTS IDENTTFICATION DOCUMENT HIGH LEVEL WASTE STORAGE TANK FARMS Occupational Safety and Health}

17.7.1

17.72

17.7.3

$\underline{17.7 .4}$

$\underline{17.7 .5}$

17.76 organizations/functional areas must implement the programs/requiramonts devaloped by the Health and Safety Organization. Several fumctional areas have significant interfaces which are described in the following sections.

\section{Engineering Design}

The Engineering Design Punctional Area defines the processes gecessary to design engineering controls for health and safety hapards. This interface is essential during the achtal design or pre-enginering phrst.

\section{Emecaency Preparedness and Management (E\&MO}

The Occupational Safery and Health Propram provides the Exwergency Preparedness and Management Functional Area with the decessary emergency planning support to sasure proper use and delineation of OSH regutations and procedures. The Occupational Safery and Healtb Organization shall also provide support for exerctses and training.

\section{Maintenange}

The Maintenance Functional Area interfaces with the Ocoupational Safety and Health Program during all routine and non-routine maintenance attivities. All personosl bealth and seftry training shall be compieted and hazard coutcols inpiemented prior to perforning work.

\section{Operations}

The Optrations Organization deperds on the controls outlined in the Health and Safety Program to safety operate. Workplace hazard identification and assessment is accomplished through walkdown inspections, surveys, monitoring and surveillances. Based on the bazards ideatified the necessary controls are defined and implemented to ensure safe operations. The Operations Organization should work closely with the Occupational Safety and Health

Program on all routine and con-routine operations.

\section{Radifition Protection}

Personnel working in radiologically controlled areas must adhere to atl ALARA policies and OSHA controls. The Radiation Protection Functional Arsa mass coordinate all routine and non. routine activities with the OSH Program.

\section{Training and Qualification}

Training is an integral part of any effective health and safety program. The Occupational Health and Safety Program provides the necessary information and support to the traíming program to ensure that effective heolth and safety training is developed and conduted. The training organization stall properly document all hesith and sofety training and matntain all such documentation in accordance with established procedures. 


\section{REQUIREMENTS IDENTITICATION DOCUMENT HIGH LEVEL WASTE STORAGE TANK FARMS \\ Occupational Safety and Fealth}

12.7 .7

17.7 .8

17.79

\section{Construction}

Al facility construction activities shall adbere to the OSHA regulations incorparated into the Occupational Health and Safery Program. The facility constnuction organization shell interface with the Health and Sofety Organization to ensure understanding and adberenco with established heaith and safety controls. Specifically, the construction organization shall adhero to OSHA's 'Construction Standards" (29 CFR 1926).

\section{Manneement, Systems}

The Management Systems Functional Ares provides the necessary controls for developing, using, and maintaining facility policies and procedures. In addition, the Health and Safety Organization sball participate in Occurreace/Event Reporting activities which are inciuded in this area.

\section{Packaping nnd Transportation}

The Packaging and Transportation of materials (both nuelear and non-auclear) involves significant inceraction with the OSH Program. Specific subjects of concern include sofe handlimg of hazandous materials and chemicals, hoisting and rigging. Personal Protective Equipment, etc.

\section{Siferuards_and Secturily}

The Safeguards and security organization has 2 limited interaction with lite OSH Program concerming the safe handling of firearms and explosives. 


\section{WESTINGHOUSE HANFORD COMPANY}

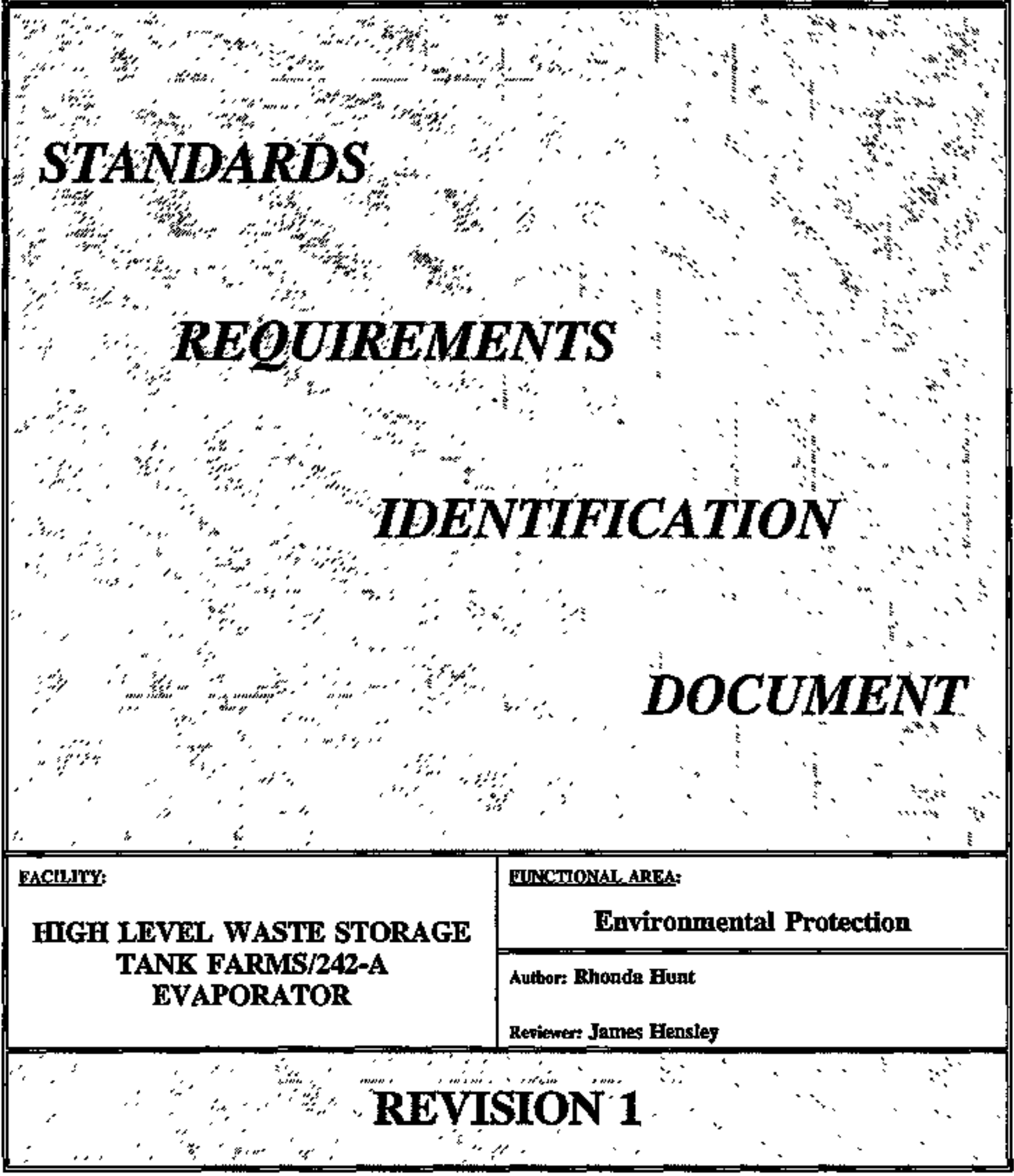




\section{STANDARDS REQUIREMENTS IDENTIFICATION DOCUMENT BRGH LEVEL WASTE STORAGE TANK FARMS \\ Environmental Protection \\ Whacerpotso}

\section{TABLE_OR CONTENTS}

18.0 ENVIRONMENTAL PROTECTION

18.1

PROGRAM MANAGEMENT

18.1.1

18.1 .2

18.1 .3

18.2

18.2.1

18.2.2

18.2.3

18.2. 4

18.2.5

18.2.6

18.2.7

18.2 .8

18.2 .9

18.2.10

18.2.11

18.3

18.3.1

18.3.2

18.3 .3

18.3.4

18.4

18.4.1

18.4.2

18.4.3

18.5

18.6
Program Policy $\ldots \ldots \ldots \ldots \ldots \ldots \ldots \ldots \ldots \ldots \ldots, 3$

Organization Structure $\ldots \ldots \ldots \ldots \ldots \ldots \ldots \ldots \ldots \ldots \ldots, 3$

Personnel Qualifications $\ldots \ldots \ldots \ldots \ldots \ldots \ldots \ldots \ldots \ldots, 4$

ENVIRONMENTAL MONITORING, SURVEILLANCE AND

INSPECTIONS

Monitoring, Surveillance and Inspection Ptans and Procedures $\ldots \ldots \ldots 6$

Water Quality $\ldots \ldots \ldots \ldots \ldots \ldots \ldots \ldots \ldots \ldots \ldots \ldots \ldots$ g

Air Quality $\ldots \ldots \ldots \ldots \ldots \ldots \ldots \ldots \ldots \ldots \ldots \ldots \ldots, 22$

Hazardous Materials $\ldots \ldots \ldots \ldots \ldots \ldots \ldots \ldots \ldots \ldots, 29$

Radiological Eftiluents $\ldots \ldots \ldots \ldots \ldots \ldots \ldots \ldots \ldots \ldots, 30$

RCRA Facility Inspections $\ldots \ldots \ldots \ldots \ldots \ldots \ldots \ldots \ldots, 32$

Dangerous Waste Tanks $\ldots \ldots \ldots \ldots \ldots \ldots \ldots \ldots \ldots \ldots \ldots, 33$

Surface Impcundments $\ldots \ldots \ldots \ldots \ldots \ldots \ldots \ldots \ldots \ldots \ldots, 36$

Quality Assuranos $\ldots \ldots \ldots \ldots \ldots \ldots \ldots \ldots \ldots \ldots \ldots \ldots, 36$

Underground Starage Tanks . . . . . . . . . . . . . . . . . . 39

Waste Piles $\ldots \ldots \ldots \ldots \ldots \ldots \ldots \ldots \ldots \ldots \ldots \ldots, 39$

PERMTTS $\ldots \ldots \ldots \ldots \ldots \ldots \ldots \ldots \ldots \ldots \ldots \ldots \ldots \ldots \ldots, 40$

Clean Water Permits $\ldots \ldots \ldots \ldots \ldots \ldots \ldots \ldots \ldots \ldots \ldots, 40$

Claan Air Permits $\ldots \ldots \ldots \ldots \ldots \ldots \ldots \ldots \ldots \ldots \ldots \ldots, 40$

RCRA TSD Facility Permits $\ldots \ldots \ldots \ldots \ldots \ldots \ldots \ldots \ldots \ldots 44$

NEPA $\ldots \ldots \ldots \ldots \ldots \ldots \ldots \ldots \ldots \ldots \ldots \ldots \ldots, 53$

POLLUTION CONTROL STANDARDS $\ldots \ldots \ldots \ldots \ldots \ldots \ldots \ldots \ldots 60$

Water Quality $\ldots \ldots \ldots \ldots \ldots \ldots \ldots \ldots \ldots \ldots \ldots, 60$

Ait Quality $\ldots \ldots \ldots \ldots \ldots \ldots \ldots \ldots \ldots \ldots, 6,62$

Radiological Effluents $\ldots \ldots \ldots \ldots \ldots \ldots \ldots \ldots \ldots \ldots, 63$

POLLUTION PREVENTION $\ldots \ldots \ldots \ldots \ldots \ldots \ldots \ldots \ldots \ldots \ldots 66$

RECORDXEERTNG, REPORTS AND NOTIFICATIONS $\ldots \ldots \ldots \ldots \ldots 75$

18.6.1

18.6.2

18.6 .3

18.6 .4

18.6 .5
Water Quality $\ldots \ldots \ldots \ldots \ldots \ldots \ldots \ldots \ldots \ldots \ldots \ldots \ldots, 75$

Air Quality $\ldots \ldots \ldots \ldots \ldots \ldots \ldots \ldots \ldots \ldots \ldots \ldots, 76$

Hazardous Materials $\ldots \ldots \ldots \ldots \ldots \ldots \ldots \ldots \ldots \ldots \ldots \ldots, 79$

Radiological Effluents $\ldots \ldots \ldots \ldots \ldots \ldots \ldots \ldots \ldots \ldots, \mathbf{8 1}$

Spills and Discharges $\ldots \ldots \ldots \ldots \ldots \ldots \ldots \ldots \ldots \ldots \ldots$. 85

Rovi:ian I

Puge i of $\mathrm{B}$ 
Tark Systems $\ldots \ldots \ldots \ldots \ldots \ldots \ldots \ldots \ldots \ldots \ldots \ldots, 90$

18.7 .2

General Operating Requirements $\ldots \ldots \ldots \ldots \ldots \ldots \ldots \ldots \ldots 96$

18.7 .3

Leak Response $\ldots \ldots \ldots \ldots \ldots \ldots \ldots \ldots \ldots \ldots \ldots \ldots \ldots, 96$

18.7.4

Ignitable, Reactive and Incompatible Wastes . . . . . . . . . 98

18.7.5

Underground Storage Tanks $\ldots \ldots \ldots \ldots \ldots \ldots \ldots \ldots \ldots \ldots 98$

18.8

GENERAL TSD REQUIREMENTS $\ldots \ldots \ldots \ldots \ldots \ldots \ldots \ldots \ldots \ldots 101$

18.8.1

18.8 .2

Performance Standards . . . . . . . . . . . . . . . . . 102

Ignitable and Reactive Wastes . . . . . . . . . . . . . 103

KEY INTERFACES $\ldots \ldots \ldots \ldots \ldots \ldots \ldots \ldots \ldots \ldots \ldots \ldots \ldots$

18.9.1

18.9 .2

18.9.3

18.9 .4

18.9 .5

Training and Qualification $\ldots \ldots \ldots \ldots \ldots \ldots \ldots \ldots \ldots 104$

Quality Assurance $\ldots \ldots \ldots \ldots \ldots \ldots \ldots \ldots \ldots \ldots \ldots \ldots \ldots \ldots$

Waste Management $\ldots \ldots \ldots \ldots \ldots \ldots \ldots \ldots \ldots \ldots, \ldots \ldots \ldots$

Emergency Management ..................... 104

Occupational Safery and Heatth $\ldots \ldots \ldots \ldots \ldots \ldots \ldots \ldots \ldots 104$

REFERENCE SECTYON $\ldots \ldots \ldots \ldots \ldots \ldots \ldots \ldots \ldots \ldots \ldots$ 


\section{STANDARDS REQUIREMENTS IIENTIFICATION DOCUMENT HIGH LEVEL WASTE STORAGE TANK FARMS \\ Environmental Protection \\ WHCEPATSO}

\subsection{ENVIRONMENTAL PROTECTION}

\section{INTRODUCTION}

The Environmental Protection (EP) Functional Area includes the technical and programmatic requirements, formal controls, and standards to assure compliance with applicable environmental laws and regulations. The Environmental Protection requirements are typically identified by the applicable law (RCRA, CERCLA, SARA, CAA, CWA, etc.) to which they are related. The Washington Administrative Code is the source of the majority of environmental regulations for permitting, media quality standards, tank specific requirements, and recordkeeping. DOE Orders 5400.1, 5400.5, 5484.I and DOE/EH-0173T specify requirements for DOE environmental programs and environmental monitoring and surveillance activities. Federal regulations such as 40 CFR 61 are utilized when there are no equivalent regulations promuigated by the state of Washington.

\section{SCOPE}

This functional area applies to the environmental protection programmatic controls, activities, personnel, and programs involved in executing the mission of Tank Farms. The physical boundaries within which the requirements of this functional area apply are the interconnecting piping, valves, instrumentation, and controls up to and including the last locked valve under Tank Farms control associated with facilities that interface with Tank Farms. Tank Farms facilities also include hazatous waste accumulation areas, a 90-day waste storage area, and underground storage tanks containing diesel fuel.

The waste storage tanks provide for storage of high-level radioactive waste containing hazardous constituents. These tanks continue to receive waste periodically from various generators through piping and transfer truck. Several tanks are confirmed leakers and require an appropriate environmental surveillance and monitoring program. Environmental regulations for tänk integrity assessments and operating requirements are applicable.

RCRA Part B permit applications have been submitted for Double Shell Tanks and the 242-A Evaporator-Crystallizer facility within Tank Farms. These facilities will be operated under interim status until the Part B permit applications are approved. Upon approval of the facility specific applications, the facilities will be requited to comply with the terms and conditions of the Hanford RCRA Permit for the Treatment Storage and Disposal of Hazardous Waste which will become effective on September 28, 1994. This S/RID reflects requirements for interim status units, and the marking and mapping requirements, imposed on interim status units by the site wide RCRA permit.

The Tank Farms contains high-heat tanks that require intemal ventilation for cooling. The ventilation systems are point source air emission sources regulated under NESHAPs. Tank Farms does not have any liquid effiuents discharging to surface waters of the State of Washington.

Tank Farms also consists of varioas contaminated ponds, cribs, and ditches which are inactive. This functional area document does not address the scope of these facilities. 
The following list identifie the programmatic elements in the EP Functional Area:

1. Program Management

2. Monitoring, Surveillance, and Inspection Plans and Procedures

3. Permits

4. Pollution Control Standards

5. Pollution Prevention

6. Recordkeeping, Reports, and Notifications

7. Tank Regulations

8. General TSD Requirements

9. Key Program Interfaces 


\section{STANDARDS REQUIREMENTS IDENTIFICATION DOCUMENT HIGH LEVEL WASTE STORAGE TANK FARMS \\ Environmental Protection \\ WHC-EPOTSO}

This clement addneses the mranigement and organizution of an effectiva EP Program. Formel orgenization of the Progrmm in vesessiry to exsare that a deliberate and controlled epprosch to Program mrmagement and execution is achieved. Establishment of such i formal organization orhences the potentitl for achievement of improved leveds of sefety performance, compliance, and efficiency. This element describes the extent of the formal Program organization structure necessary to define and commmicate where personnel are essigned, what tasks they are expected to accomplish, methods for accomplishment, and maragement's expectations for performance.

\section{Properam. Policy}

Commintication of gito manggemeat's commitwent to the safecty and bealth of workers, the

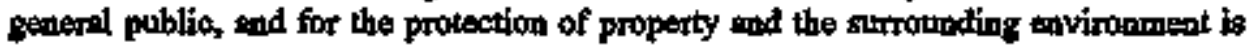
acoonglisked through the developunent, distribution, and implementatinn of an EP palicy atmement. The policy statement describes the secpe, general philosophy, and the standards of

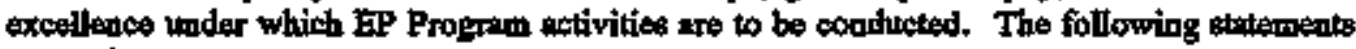
from DOB Order \$400,1 provide the general DOE policy statement and triplementition pisan.

\section{FACILITY REQUIREMENT SOURCE: DOE5400.1 Chapter V, Section a}

"It is DOE policy to conduct its operations in an ervironmentally safe and soned manner. Protection of the environment and the public are responsibilities of paramoums importance and

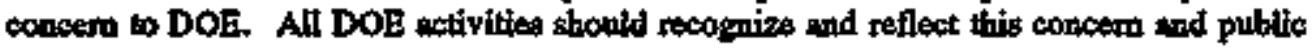
trust. To that end, DOE is firmly committed to ensuring incorporation of national environmental protection goals in the formulation and implemeatation of DOE programs. It has en equal commitmont to advance the goals of restoring and enhancing envinommental quality, and ensuring public bealth. Accontingly, it is DOE policy to conduct the Department's operations in compliance with the letter and spirit of applicable environmental stahutes, regulations, and stapdards, In adifition, DOE is committed to good environmental mastagenent of all its proprams and all iss facilities to correct existing envirammental problems, to minimizh risk to the eavimonment of public health, and to enticipate and eddress potential environmentel problems bofore they pase a threat to the quality of the environment or tho public welfare. Finally, it is DOE's policy that efforks to met environmental obligations be carricd out consistently acrose all openutions and amang sll field organizations and programs."

\section{Orgamization Stroncture}

This subelement specifies requirements for organizational structure and persomel responsibilities for madiological maritoring programs. The source of this requirement is NRC Regulatory Guide 4.15, therefore it is considered a best management proctice.

\section{FACILITY REQUREMENT SOURCE：USABC-RG1.86 Section C.1}

-Organizational Structure and Responsibilities of Managerial and Operational Personnel

The structure of the organization ws it relates to the mansyement and operation of the monitoring program(s), inchuding quatity ssstrance policy and functions, stiould be presented. 


\section{STANDARDS REQUIREMENTS DENTIFICATION DOCUMENT HIGH LEVEL WASTE STORAGE TANK FARMS \\ Environmental Protection \\ WAC-EP-O3SO}

The anthorities, duties, and responsibilities of the positions within this organimation down to to firstine supervisory levet should be deseribed. This should include responsibilities for arview and approvel of writter procedtres and for the preporation, reviow, and exthention of monitoring dete and reports.

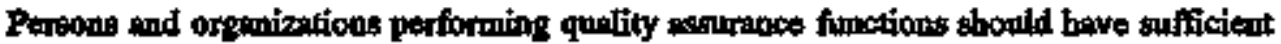
suthorily and arganizational freedom to identify quafity problems; to initiate, recommend, of provido onlutions; and to verify implementation of solutions."

\section{Personnel Ousalifications}

This gubelement speciftes requirements for persomel qualification it ratiotogical monitoring proprame. The source of this requirement is NRC Regulatory Guide 4.15, therefore it is cousidered is best manigement practlos.

\section{FACIMTY RDQUIRMENT SOURCE: USAEC-RG1.86 Section C.2}

\section{Specificetion of Qualifications of Personnel}

The qualifications of individuals performing radiological monitoring to conty out their assigned funetions should be specified and documented (a.g., as in a job desctiption).

An indoctrimation and orientation program, appropriats to the size and complexity of the orgurizotion, and to the setivities performed, should provide that (a) pensoonel performing quality-felated activities are tratned and qaslified in the principles and techniques of the activities performed, (b) personnel are made aware of the nature end goals of the quality assurance program, and (c) proficiency of personmel who parform activities affecting quality is modo by retraining, ro-axdmining, and recertifying or by periodic performance reviews, a ippropriate."

\section{ENVIRONMIFNTAL MONITORING, SURVEHLANCE AND INSPECTIONS}

This elenedet includea the creation and implemeatation of monitoring, surveillanke, and inepection plans and apecific monitoring and surveillance methods designed to prevent, detect, and mitigats leaks, spills, diseharges, otc. Examples inchudo ambient sir quality gurveilhance standards, point source discharge monitoring, and havartous wasto site monitoring. The following programmatic requirements are specified by DOE Otder 5400.1.

\section{FACILITY REQUIREMENT SOURCE: DOE5400,1 Chapter IV, Section 3}

"Properational Monitaring of Facilities, Sites, and Operations. An environmental study shall be condected prior to stut up of a new sits, fuctity, or process which has the potential for gignificant efverse environmental impact. The preoperational shuly should bogin not lest than 1 year, and preferebly 2 years before start up to ovaluate seasoonl changes. The study shall serve to: characterize existing physical, chemical, and biological conditions that could be affected; estoblish background levels of radioactive and chemical components; characterizs pertinent environmental and ecologic parameters; and identify potential pethways for humon exposure or exvironmental impact as a basis for determining the nature and extent of the

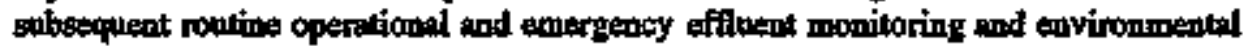




\section{STANDARDS REQUIREMENTS IDENTIIICATION DOCUMENT HIGE IEVEL WASTE STORAGE TANK FARMS \\ Environmental Protection \\ WHCER-0750}

garveillence progrante. Where time and cinumbtandes do not allow for completion of

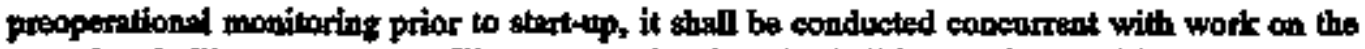
new site, freility, or procese. The preoperotional study shall be consistent with NEPA complience entivitiea

Where spropriate, antivities and documentation conducted for NEPA complienco may aubetitute for complinges with thits requitement."

\section{FACULITY REQUIREMENT SOURCE: DOE5400.1 Chapter IV, Section 5.9}

\section{Efflemet Monitaring}

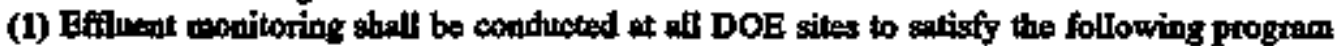
objectives:

(a) Verify compliance with applicable Federal, State, nod local effluout requlations and DOE Orders.

(b) Determine complince with commitments made in Environmental Impact Statements,

Envitamental Assessments, or other of ficiol documents.

(c) Evalunte the effectiveness of effinent treatment nod contrat.

(d) Identify potortial eavironmental problems end evaluats the need for remedial sctiona or mitigation meesures.

(c) Support permit revision andior reissuance.

(i) Detect, characterize, and raport unplanned raleases."

\section{FACIITY REQUIREMIENT SOURCE: DOR5400.1 Chapter IV, Section 5a(2)}

"(2)Efiluent mooitoring shall comply with applifable regulations and thit be condneted to provide representative messuresents of the quantities and conccentrations of pollumbuts in liquid and nintorne discharges, and solid wastes.

(a) Monitoring Stations. Effluents from on-site waste treatment or disposal systema shall be monitored in accordonce with appliceble regulations. Influents to on-site wasto treatmeat of disposil systems should be monitored as needed.

(b) Sampiting. Sumpits collection prograum aball reflect spexific factitity needy. Type and

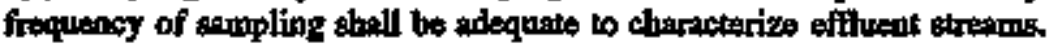

(c) Samplo Anatyrin. Standard analyses shall be used to toalyze sanuples whenever swch methods ane required by regulatory programe.

Exemptions dwe to analytical problems or for non-routine aualyses may be employed sfter receiving approvel from the appropriate regulatory agency. Analyses uot repuired by regulations may be conducted a determined by site-specific conditions.

(d) Monitoring Data Recond kecping. Auditable reconds shall be eatablished in accortauce with the rexplirements of DOE 5700.6B."

\section{FACHITY REQUIREMIENT SOURCE: DOE5400.1 Chapter IV, Section 5.b}

Environmental Surveillance

(I) Environmental surveillance shall be conducted to monitor the effects, if any, of DOE

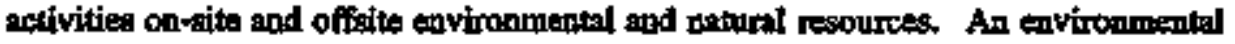
surveillance screening program shall be ubdertaken at DOE sites to determine the need for a pernonent sarveillance program. Envirommental sarveillance shall bo destigned to sstisfy obe or more of the following prograin objectives:

(a) Verify compliance with applicable environmental laws and regulations; 


\section{STANDARDS REQUIREMENTS IDENTHICATION DOCUMENT HIGH LEVEL WASTE STORAGE TANK FARMS Environmental Protection \\ WIC-EP-0750}

(b) Vexify compliance with environmentel commitments made in Environmental Irmpget Statements, Envirommental Assessments, Sifety Anelysis Reports, or other of ficial DOE documents;

(c) Characterize and defins trendr in the physical, chemical and biological condition of enviroamental medis;

(d) Estahlish beselines of envimonmental quality;

(o) Provide a continuting assesement of pollution ahatement programs;

(f) Identify and quantify new or oxisting euvironmental quality probleme.".

\section{FACIIITY REQUIREMENT SOURCE: DOR5490.1 Chapter IV, Section 5.b(2)}

"Environmental gurveillence programs and compopents should be determined on a sito-specifie basis by the Fetd organization. Programs sbould reflect fanility sbaracteristics, applicable regulations, hazond potential, quautities and concentrations of meterials rilleased, the extent and use of affected hir, land, and water, and specific losel pablic interest or concern. Surveillance progrnms are tikely to include one or mare of the following:

(a) Manitoring stations;

(b) Sumpling and andysis; and

(c) Moxitoring data recordkeeptiog."

\section{FACILITY REQUIREMENT SOURCE: DOE5400.1 Chapter IV, Section 7.a}

"Rutiological Monitoring - Requiremeots for the environmental monitoring of radiosetive materials are to bo found in DOE Orders in the 5400 series dealing with raciation protection of tho public and the enviromment. Airborne radiation and radionetive materials discherged from DOE failities complly with the requiremeats of 40 CFR Part 61, "National Emisstion Strodisuls for Hezinilous Air Pollutants. "Further, for those radioactive materidls not regulated under the Clean Air Act, DOS has established standards to meet its responsibilities under the Atowic Epergy Act."

\section{FACILITY REQURREMANT SOORCE: DOES400.1 Chapter IV, Section 7.b}

"An assesement of the potential radiation dose to members of the public which could have resulted from sits operations shall be made for facilities required to conduct effluent and environmental rediological monitoring. Assessments shall be made in accordance wilh the requirements of DOE Onders in the $\$ 400$ sertes dealing with radiation protection of the public and the environment."

\section{Monitorina, Surxeillance and Inspextion Plans and Procedures}

This subelement wdresses the requirements for preparing monitoring, surveillance and tinspection plans and procedures. Monitoring plans describe the conduct of routine dats collection programs designed to provide required ervironmental data. Inspection plans describe the conduct of periodic, noutins inspections of facilities and equipment used to collect exvironmental data. Procedures provide the specific instructions for conducting activitien under the monitoring, aurveillance end inspection plans. The Environmental Momitoring Plan (EMP) and Pueility Effluent Monitoring Plan (FEMP) shall contain the rationale, design and operationel criteria for monitoring and sampling programs; the extent and frequency of mouitoring and sampling; procedures for laboratory anslysis; quality assurance requirements; 


\section{STANDARDS REQUIREMENTS IDENTIFICATION DOCUMENT HIGE LEVEL WASTE STORAGE TANK FARMS \\ Environmeatal Protection \\ WHC-ET-OTSO}

and direction for the preparation and disposition of reports. NRC Regulatory Guide 4.15 provides guidince on monitoring program procedores and is consideref a best monogement practice.

\section{FACILITY REQUREMMENT SOURCE; DOE/EA0173T Section 10.3.1}

Reqpired written procedures covering monitoring metivities melude the following topica:

Enviroumeatil and effiuent sampling

Ground-water sampling

Continuona envirommental and effluent monitoring systems

Laboration malysis

Dakn management and calculations

Transport and pathway modeling

Dose odikulations.

Review and reporting of results"

\section{FACILITY REQUREMIENT SOURCE: DOB3400.I Chapter IV, Section 4}

-Environmental Monitoring Pling, A written environmental monitoring plen shall be prepaned

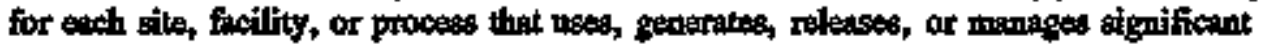

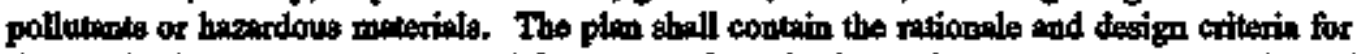
the monitoring program, exteat xad frequency of monitoring and messurements, procedures for

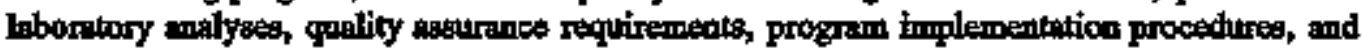
direction for the preparation and disposition of reports. The plen aball be approved by tho approptrite Head of Field Organization, or his ar har designee. The plad ahall be reviewed anrually and updeted as neded. The plun shall identify and diseuss two major activities (a) effluent monitoring, and (b) environmental arveillence. The plan shall reflect tho ingortance of monitoring th a critical element of in effective environmental protection program. The plan shill be reviewed anmatly and updated every 3 years."

\section{FACILTY REQURREMENT SOURCE: DOR5494.t Chapter II, Section 4,}

"Scope and Content of Environmental Monitoring Program, Reports, and Summarieg. Envirunmental Monitoring. Programs for maritorimg the enviramment sball be coaducted at Depertment of Euergy sites to determine:

Coupliance with the requirements of Order DOE 5480.1, Chaptera $\mathrm{I}$, XI, and XII.

The background levels and sib contribution of radioactivity; and, as eppropriate, other pollutents, in the sate environg. 


\section{STANDARDS REQUIREMENTS IDENTIFICATION DOCUMENT BIGE LEVEL WASTE STORAGE TANK FARMS \\ Environmental Protection \\ wickerso}

Compliance with appliceblo environmental quality and public expoeure litnits and other environmental comenitmente (e. B., those published in exvironmentel impect etotements or other official documents)."

FACILITY REQUIREMENT SOURCE: DOES484.1 Chapter Hi, Section 5.e(1)(a)

"Monitoring Gridelines.

(1) Generpl.

(a) An a general rule, monitoring sbould be conducted in a manner that provides acourote preasurements of the quantity and concentration of liquid and airborne pollutants in effiluents as a besis for:

1 Determining compliance with applicable discharge and effurent control limits, ineluding self-imposed administrative limits designed to assore complience with in-plant operating limits, effluent stendands or guides, and with envirommental standarda or guides.

2 Evaluatiog tho edequacy and effectiveness of conksinment and waste treatment and controt as well os of efforts toward achioving lovele of radioactivity which are as low ac reesonsably achiovablo considering technienl and economical constraints.

3 Compiling an annual inventory of the redioestivity released in effluents and onsite dischargeg."

\section{FACILITY REQUREMENT SOURCE: DOE5484.1 Chapter II, Section 5.c(2)}

"Monitoring Locations. Measuraments of vo'ume, rate of discharge, content, etc., should be made, insofar as is practical, at the point at which the data most closely represent whet is being rekased. This implies that mensurements should be made at the point of discharga, though there are exceptions. Effitueats should be monitored it the point at which the applicable stondards apply. In the cose of onsite discharges, the monitoring location may bo the whiste bestmeat or disposal system; and in case of effluents, the monitoring location may be the point of release to the offite environment after all treatment aud control, fucluding retiontion and decay, hove been offocted. In many instances, the monitoring location is tpecified in a discharge of operating permit."

\section{FACIITY REQUIREMERT SOURCE: DOR5484.1 Chapter II, Section S.e(3)(a)}

"Typs and Fraquency of Sampling.

(a) Sempling frequency and type ehould be determined by considering the purpose for whitch the deto are being obtoined, e.g., evaluation of the effectiveness of waste trealment and control, complinnce with operating limits of applicabile effluent or performance standands, compliation of releass data, etc. Continusous sampling is desirable and may be neceseary where thare is wide varietion in the concentrations or mixturs of potential pollubaits in the offluent atrem. However, periodic sampling may suffice when the cancentration and miztumes tre reasonelby constent and there is little likelihood of unusuat variations. Similarly, proportional sampling mey be necessary when effituent flow rates fiuctuate, whereas a representalive grab-aample may suffice for batch discharges. The method of sampling may bo specified in the epplicuble regulation or permit."

FACILITY REQURREMENT SOURCE: DOE5484.1 Chapter II, Section S.e(3)(b) 


\section{STANDARDS REQUIREMENTS IDENTIFICATION DOCUMENT HIGE LEVEL WASTE STORAGE TANK FARMS \\ Eivironmental Protection \\ WHC-ER-THS}

For purposes of reporting rwiological data, gross radiosctivity measurements are generplly inadeppite. They are appropiate only:

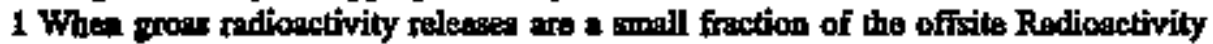
Concentration Guides (RCG's) for "unidentified mixhures" and are of no health or environmentst siguifiesmce;

2 When the retative concentrations of specific rodionuclides are so well known by other means that gross radioactivity meesurements are truly indicative of the activity being released; of 3 Whe the activity of waste strearrs is so fow 29 to prechude specific nuclide measurements."

\section{FACH.MY REQUIRTMENT SOURCE: USAEC-RG1.86 Section C3, Paragraph 1}

Written procedtures should be pripared, reviewed, and approved for activities involved in carrying out the monitoring program, including sample collection; packaging, shipment, and recespt of samples for offsite analysis; preparation tud analysis of sampies; maintenance, storage, and use of radionctivity reference stapdards, ealibration ind checks of radiation and radioactivity wescurement systems; and reduction, ovaluation, and repporting of date Individunts who review and approve these procedures should be knowledgeable in the salijects of the procedures."

\section{Water Ouality}

This subelement specifies the requirtmentr to monitor the effecte of operations on groundwater quality and dischargas from tbe 242-A evaporator. There are no discharges to unface weter from Tank Ferrmr. Reguirement soures include DOE 5400.1, DOEVEH-0173T, and WAC 173-303. The feotrote for the ward "should" in this document indiextes performence eriteria and prosedures required to operate and matintain an eceptable radjation protection program for the pablio and the enviromment.

\section{FACILITY REQUIREMENT SOURCE: DOE/EHO173T Section $\mathbf{2 . 0}$}

-All liquid effluent atreame from DOE tacilities should bo eveluated and their potential for releass of radiometidsa assessed. This cvaluation is required to adexpately control such releases. The results of this assesement provide the basig for the facility'a Effituent Monitoring Progroin (DOB 5400.5), which should bo documented in the site Environmental Monitoring Plen (as describet in DOB 5400.1), to ahow:

- Bffluent monitoring (sempling or in situ messurement) extrution locitions used for providing quantitative effluedt relesse dats for each outfill;

- Procedure and equipmeat used to perform the extraction and neasurements

- Frequency and anslysis required for each oxtraction (continuous moaitoring and/or sapling locetion;

- Minimam detection level and exenracy;

- Quality assorance components;

- Eftuent outfall alarm sattings and basis.

Liquid offivent from DOE-controlled facilities that have the potential for radioactive contamination should be monttored in accordance with the requirements of DOE 5400.1 and 


\section{STANDARDS REQUIREMENTS IENTIFICATION DOCUMENT HIGH LEVEL WASTE STORAGE TANK FARMS \\ Environmental Protection \\ wherpento}

DOF 5400.5. As appropriate, companent systems may be grouped and standerd procedures referenced."

\section{FACIUTY RDOUIREMENT SOURCE: DOERAT0173T Section 2.2, Sentence I}

"The selection of modification of a liquid effluent monitoring system should" be beged on a

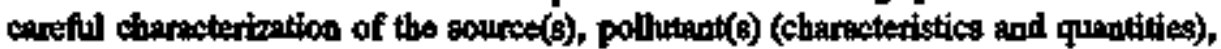

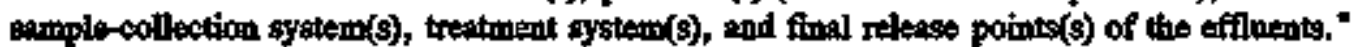

\section{FACIITY REQUREMENT SOURCE: DOR/GHO173T Section 2.2 .1}

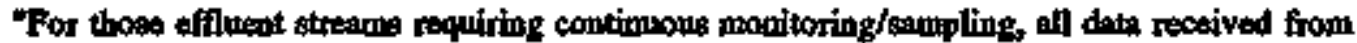
the continnous monitoring syatem thould be used whed perfornotiog statistical antlyses, In the caso of diechergo poifth relessing tariconbelides emitting alphe or weak beta radiation, with no documentable patios to beta andior gantma emitters that could bo used as indicator radionuclites (1.e., whoro it is not technologically feasible to mouttor contimnousty), coutimuous proportionsal minpling and robalysis can bo used as an alternative to continunus monitoring. Elowever, the consideration of usw technologites to cantingously monitor such effluent streams is encounged."

\section{FACILUY REQUIREMENT SOURCE: DOE/EH0173T Section 2.2 .2}

"Sempling systems should" be rufficient to collect representmive sempoles that provide for an adequate record of releases from a tacility, to prefict trends, and to satisfy needs to quantify riteneses."

\section{FACILITY REOUIREMINT SOURCE; DOEJEH0173T Section 2.2.3}

"Continuous monitoring and apling systems should" be calfibrated before use and recalibnated any timo they aro subject to meintenance, modificelition, of system changes that

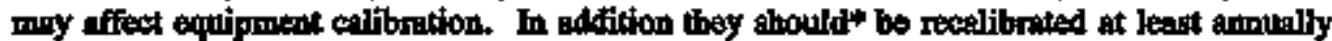
and routinoly checked with known sources to determine that they are consistently flmctioning properly. Calibration(s) ahould be performed in a menner consistent with manufacturers" instruction and specifications. Exeh system should be checked on a routine basis, at lesst weaty. Sampling bystems strould bs fanctioning properly beforo a facility is plased in operation. The tise of redumdent sampling systems may be necessary to provide adequate sampling capubilities and prevent dekays in process operation."

\section{FACILTY REQUIREMIENT SOURCE: DOEHED0173T Section 2.2.4}

"Environmental conditions (e.g., trmpenture, humidity, radiation level, dusts, and vapors) should* be considered when locating sampling and monitoriag systems to avoid conditions that will influeses the operation of the systate. Off-line liquid trinsportiong lines should be replaced if they become constemineted to the point wheto the sensitivity of the system in affected) with tafioactive moterisls or if they becoms ineffectivs in meeting the design bosis within thestoblished accuracy/confidence lovels."

\section{FACILITY REQUIREMENT SOURCE: DOE/EH0173T Section 2.3.1}

The following oritesia stould be cousidered when operattog a liquid effluent sawpling system: 


\section{STANDARDS REQUIREMENTS IDENTIFICATION DOCUMENT HFG LEVEL WASTE STORAGE TANK FARMS \\ Environmental Protection WHC-EPO750}

- Location of anmiling and monitoring systems

- Use of a parmp in areas where necessery to provide a uniform continumas flow in the main sample line

- A redundant Eample-collection system or one of the following alternatives to perrrit continted gampling during replacemeat or servicing of the systemser 1) a substitute eample-transport system, 2) the capability to shut down the system for fast repair, or 3) an altarnatis method for estimating releses when the system is not capable of operating

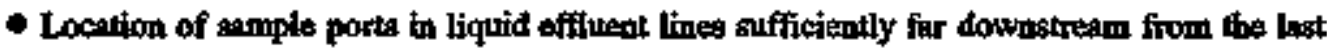
feeder line to allow complete mixing (as complete as possible) of liquid fand design of the somple port to allow intake of a proportionel part of the liquld effiluent stream

- Capability to determine the effluent atrom sad sample-line flows within at accuracy of at lenst $+1=10 \%$ <percents

- Design of the syetem to minimize deformation and sedimentation and to pravent freezing of efftuent sample lines."

\section{FACILITY REQUUIREMENT SOURCE: DOEJEH0173T Section 2.3.3}

"The sampling ports should be 1) positioned downstream from the last component stream entering, in a locetion that will provide complete mixing and 2) designed to accommodate a proportiond amount of the fill ragge of effluent flow for transport to the collection system. If proportionality cannot be sutomated, both the effitent and worple flow rates should be meacured"

\section{FACIIIT REQUIREMIENT SOURCE; DOE/EH0173T Section 2.3.4}

The integrity of the juntion of the liquid-semple tine with the sampling port is importint. Liquid offinent lines con axpod and contract considerably, depending on the thermal lowding variation in the line(s). Consequently, desige for strch a junction should consider either line

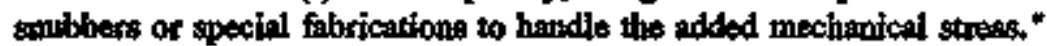

\section{FACILTY REOUIREMENT SOURCE; DOERHO173T Section 2.3 .5}

-Unless sufficiendy high and constont hydralic pressure exists within an effluent system, a sampling pump of high reliability should be installed. Removal of the sample from the liquid efflusat line where 2 sanping pump is required should be weomplisbed using a construt-volume pump that witl mintati a constant flow, regandless of line pressure changes."

\section{FACIL.TYY REQUREMIFNT SOURCE: DOE/EH01737 Section 2,3.6}

The dasign of the collector portion of the sampling system should allow for the collection of a sample that is consistent with the methoxd of enalysis. For exemple, if the effiuent stream has a surgll flow, a small container might be used to obtain a grab sample that is counted directly in the laboratory. If consentration of the sample is necessary, a large-volume sample will bo nexeasary. If the collection system requires messured aliquots taken sexpentially every few minutes, then both the frequedcy and required sensitivity of analysis beve an impact on the size of the consontiner to be used. The sample line should be routed back to either the effluent line 


\section{Environmental Protection \\ whCER-0750}

of a wasto treatment system. Thus, lacetion of the canule collection system ean be based in pert on the retum flow of the sempils line."

\section{FACILITY REQUIREMENT SOURCE: DOE/EAEIT3T Section 2.3.8}

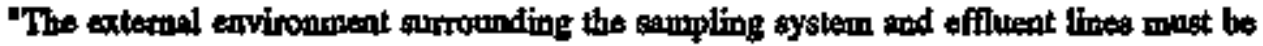
considened. The eampling system stroald bo protected from atverso environmental factor incluning unosurl operational impacts. At semple callection points, the ambient dose rate originating in the efflosot line(s) and the sampling apporatus should be ovaluated for

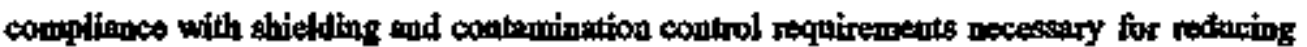
worker axpagure. Componedte of the sanpling system should be readiby accessible for maintenance."

\section{FACILITY REQUIREMIENT SOURCE; DOE/EH0173T Section 2.4}

"Design considerations for liquid effluent momitoring systems sbould includs the purpase of the monitoring, the types and levels of expected rationuclides, potential beckeround dose rates, expecied duration of releases, end environmental effects. Ore of the primary purposes of using a monitoring syetem is to utilize its ability to provide a prompt signal if a significent neleses oceurs. Thus, the output sigael from monitoring systems shonld be contimuously monitored by responsible personnel. In exdition, written response procedures should be

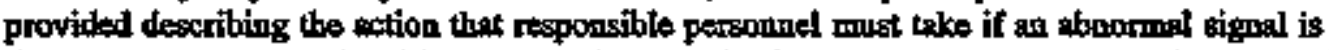
detected. The ontput siogal instritumentation, monitoring system noconders, and alisms should* be in a location then iv coutinunasly occtipied by operations or sectrity personnet."

\section{FACIITY REQUIREMENT SOURCE: DOE/FHOI73T Section 2.4.5}

"Radiasctive material in effluents occasionally originates from a fluctuating source(s). If the content and radiosetivity concentration are constant but the release is of strort duration, the effluent is considered a "batch" redease. Before a batch is released, a representative grab sample ahould be drawn and malyzed to determine releasability. If the effluent originates from a contimuting source(s), it is considered a "contimuous" stream and stoold be conbimuonsly monitored andior sampled."

\section{FACILITY REQUIREMENT SOURCE: DDE/EH(0)73T Section 2.5}

"To sigan the need for corrective actiong that may be necassary to prevent public or environmental exposures from exceeding the limits or recommendations piven in DOE 5400.5,

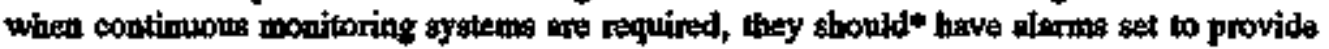
timely wornings. To preveut the cumulative impects of smoll releases from producing a

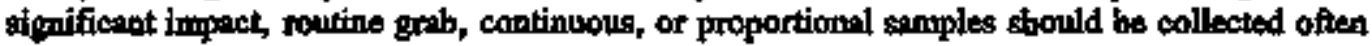
outagh to detect minonuchides of interest including thase with relatively short halflives."

\section{FACILITY REQUIREMENT SOURCE; DOEJEH0173T Section 2.6}

"As they apply to the monitoring/sampling of liquid efficents, the ganeral quality assurance program provisions of Chapter 10 <DOE/EH-0173T> sheuld* be followed Specific quality sssuranco requirements for the faility's liquid effluent monitoring program aro to be contained in the Quality Assurancs Plan ascociated with the facility." 


\section{STANDARDS REQUIREMENTS IDENTIFICATION DOCUMENT HIGH LEVEL WASTE STORAGE TANK FARMS \\ Environmental Protection \\ WHC-ER-0750}

\section{FACHITY REQUIREMENT SOURCE: DOES400.1 Chapter IV, Section 8.d(1)}

Water Monitoring - Environmentel Surveillence

(1) Ambieut water quality monilaring should be conducted through a netoratit of fixed stationg from witich data will establist well-defined histories of the phyeical, triologicel, and chernical conditions of locel bodies of water and eedimenta. The dath obtained from this network should be coordinated with other monitoring activities. Water quality dato may be obteined from existing Stats ind lool monitoring stations."

\section{FACILITY REQUIREMENT SOURCE: DOES400.1 Chapter IV, Section 8.d(2)}

"Analyeis of deta collected from a fixed station monitoring network should support:

(A) Cheractarizing aod defining troods in the phystcal, chamical, and biological coodition of surfiue waters;

(b) Estabitibhing baselines of water quality;

(c) A continning wssessment of water pollution control programs;

(d) Identifying new water gality problems; fod

(e) Defecting, characterizing, and reporting unplanned relegses sod their effects on whter quality."

\section{FAClLITY REQUIREMFNT SOURCE: DOE5400.1 Chapter TV, Section 8.d(3)}

"Monitoring networks shonld bo operated and maintained in a uniform manner, i.e., through establisbed prosedure that allow comparative evaluations of tath from monitoring sathes.

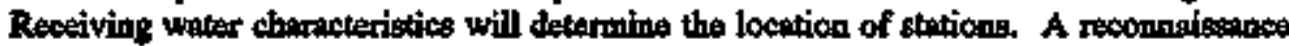

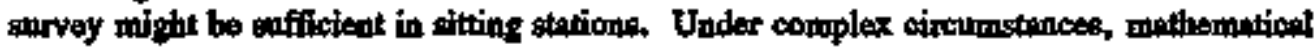
modeito condd be needed to select atotions sites."

\section{FACILIMY REQUIREMENT SOURCE: DOE5400.1 Chapter IV, Section 8.d(4)}

Tonitoring prograns wre best served by fixed station netwonks. However, a networt of efficent monitoring and selected mobile monitoring stations could satisty the neede at some facilities"

\section{FACTIYY ReQUIREMENT SOURCE; DOF5400.1 Chapter IV, Section 8.đ(5)}

"Surface weter sempling performed at fized monitoring stotions will charactertze physicul and shemicol properties of the water columen and sediments, and biological specieg in the whiter colnmin and benthos. Types of sampling performed should depend upon locel conditiona and the veriability of stream cheracteristies and water quality."

\section{FACILTY REQURREMENT SOURCE; DOES4(10.1 Chapter IV, Section 8.d(0)}

"The monitoring frequency at a fixel network station is a function of the variability of the ohemist, phystcel, and biologicel conditions of the water body. Data collected shall be atpresentative of the vartations in water quality and changes in poltutant loads. Varyings

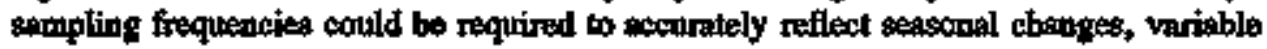

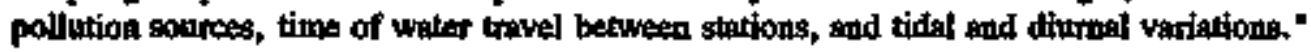




\section{STANDARDS REQUIREMENTS IENTIFICATION DOCUMENT HIGF LEVEL WASTE STORAGE TANK FARMS \\ Envirommental Protection \\ whtc-ERonso}

\section{FACILITY REQJIREMENT SOURCE: DOE5400.1 Chapter YV, Section 8.d(7)}

-Ambient witer quality monitoring servea to confirm compliance with the Clean Water Act. An understending of the Water Quntity Management (WQM) process implemented by EPA, the Stetes, intergtate ngenties, and aren-wide, locel and Repioral plenning organizations is esential to the desiper of a water quality monitoring program. The elements of the WQM proceseses aro destibed in 40 CFR Part 130. Test procedures for pollutant enalyeen aro bisted in the 40 CFR Part 136."

\section{FACILITY REQUIREMIFNT SOURCE; DOES400.1 Chapter IV, Section 9}

"Groundwatar Monitoring Program. Groundwater that is or could be affected by DOE activities ahall be monitored to determine and document the effects of operations on groundwater quelity and quatity and to demonstrate compliance will DOE requirements and appliceble Federal, State, and local lawa and regulations."

\section{FACILTY REQUIREMIENT SOURCE: DOES400.1 Chapter IV, Section 9.a}

"Groundurater Momitoring Flans. A grountwater monitoring plan shall be devaloped as a specific element of all environmental monitoring plans and the Oroundwater Protection Menegement Pnogram required in page III-2, subparagraph 4.e. The plan shall identify all DOE requirements and regulations applicable to proundwater protection and inchude monitoring strutegy. The elements of the gromatwater mmitorting program shall be specified (sampling plan, samplinge, analysis, and dem management), as stall the rationale or purpose for selecting these elements."

\section{FACILITY RBOUIREMENT SOCRCE: DOB5400.1 Chapter IV, Seetion 9.}

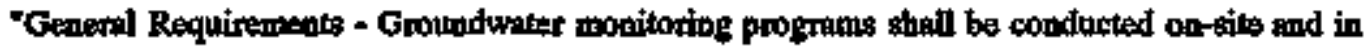
the vicinity of DOE focilitite to:

(1) Obtoin daks for the purpose of determining beselime conditions of proundwater quality and quantity;

(2) Demanatrats compliance with and implenentation of all applicalble regularions snd DOE

Orders:

(3) Frovide date to parmit the enty detection of grounduater pollution or contamination;

(4) Provide a reportiog mechonism for detected groundwater polfution or conteritionation;

(5) Identify existing and potential grounduater contamimation sourtes and to maintain sarveillence of thess sources;

(6) Provide date upon which decisions cen be made coucerning toud fiepasal practices and to madagement and protection of groundunter resources."

\section{FACILITY REQUIREMIFNT SOURCE: DOBS400.1 Chapter IV, Section 9.e}

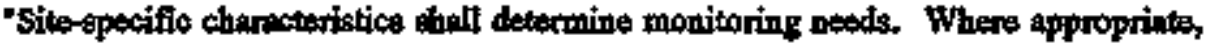
groudwater monitoring programs shall be designed and implemedted in accordince with $\mathbf{4 0}$ CFR Part 264, Subpart F, of 40 CFR Pant 265, Sulpart F. For sites with moultiplo groundwater pollutant sources, extensive groundwater pollution of othsr uniquse site problems, 


\section{STANDARDS REQUIREMENTS IDENTIFICATION DOCUMENT FIGH LEVEL WASTE STORAGE TANK FARMS \\ Environmental Protection \\ WHC-EP-OTSO}

groundwater monitorins prograns could requipe more extengive information than those

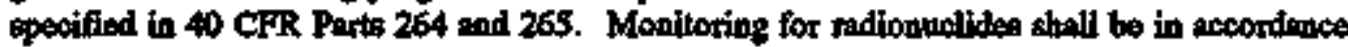
with DOE Onlers in the 5400 series dealing with radietion protection of the public wod the eavironment."

\section{FACIIIY REQUIREMENT SOURCE: DOE5820.2A Chapter I, Section 3.b(3)(n)}

-A eyatem of gromnd water or vadose zone monitoring wells meeting the Resource Conservation and Recovery Act requirements per 40 CFR 264 shall be installed, as a minimum, around clusters of liquid waste storngo tenks."

\section{FACIITY REQUIREMENT SOURCE: WAC-173-303(931208) Section 645( 8)(a)}

(8) Generel gnound water monitoring requirements.

The owner or operritos must comply with the requirements of this subection for any ground water monitnring program developed to entisfy suhsections (9), (10), of (11) of this section. (a) The ground water monitoring syatem muss consist of a sufficient number of well, installed It approprivte locations and depths to yiedd cround water semples from the upparmost equifer thint:

(i) Represent the qualtity of background water that has not been affected by leatrage from a regulated units

(A) A determination of background quality may include sampling of wells that are not hydrenlically upgradient of the waste management anea whene: (I) Hydrogeologic conditions do not allow the owner or openator to detemine what wells are hydraulically upgradient; and (II) Smoling at otber wells will provikj an indication of beckground ground watter quality that is representative or more representative than that provided by the upgradient wells; and (ii) Represent the guslity of ground weter passing the point of complismce. (iii) Allow for the detection of contamination when dangerous waste or dangerons constituents heve migrated from the wrasto mangoement aree to the uppermost aquifer."

\section{FACIITY REQUIREMENT SOURCE: WAC-173-303(931208) Section 645( 8)(b)}

(b) If a facility conkains more then oae regulated umit, separate ground water momitoring syntems are not required for each regulated unit, provided that provisions for sampling the

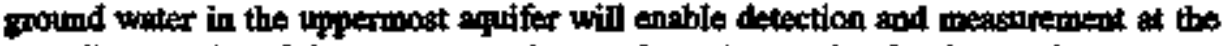
complitince point of dengerous constituents from the regulated mits that have estered the ground water in the uppermost aqgifier."

\section{FACHITY REQUIREMENT SOURCE: WAC-173-303(931208) Section 645( 8)(c)}

"(c) All monitoring welts mast be cased in a menner that motintains the integrity of the monitoring well bore hole. This cesting must allow collection of representetive ground water samplea. Wealls must be constructed in sueh $n$ manner as to prevent contamination of the samples, the sampled strats, end between aquifers and water bearing strata. Wells must mest the requirements set forth in Parts 1 and 3 of chapter 173-160 WAC, Minimum standards for ccuntrution and maintengence of wello."

FACIITY REQUIREMENT SOURCE: WAC-173-303(931208) Section 645( 8)(d) 


\section{STANDARDS REQUIREMENTS IDENTIFICATION DOCUMENT HIGH LVVEL WASTE STORAGE TANK FARMS \\ Envirommental Protection \\ Whe-epurso}

"(d) The ground water monitoriog program must include at a minimam, procedures and techinitutes for:

(i) Decontermination of drilliog and empling equipurent;

(ii) Seumple collection;

(iii) Samplo proservation and shipmisat;

(iv) Analytioul procedures and quality aspurance; and

(v) Chain of custody control."

\section{FACILITY REQUIREMENT SOURCE: WAC-173-303(931208) Section 64S( 8)(e)}

"(e) The ground water monitoring program mast inelude consistent sampling and amalytical methods that ensure reliable ground water samgling, sccurately messurs dangeroms constipuents and indicator parameters in ground water samples, and provide a reltable indication of groundwater quality below the waste managemeot aren."

\section{FACALIY REQUERMENT SORRCE: WAC-173-303(931208) Section 645( 8)(f)}

"( $f$ ) The ground water monitoring program must include a determination of the ground water surface elevition each time ground water is anmpled."

\section{FACILIYY REQUIREMENT SOURCE4 WAC-173-303(931208) Section 645( 8)(g)}

"(g) In detection monitoring or where appropriats in compliances monitoring, data an ench dengerous constiment epecified in the permit will be collected from beckgrounil welle and wells the coumptiance point(s). The mumber and kinds of samples collected to establish beckground shall be approprinte for the form of statistical test employed, following generally secepted atatistionl principles. The equole size stall be as large as necesenty to ensure with

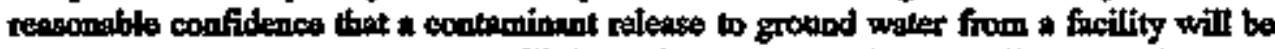

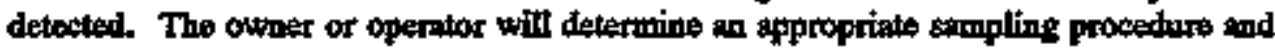
interval for equh boardow constimest listed in the froility permit which shall be opecified in the unit permit upon approval by the departoutat. This sololing prosedure aball be: (i) A sequence of at least four somples, coken at in interval that assures, to the greatest extent technically feasible, that in independent sample is obtained, by reference to the uppermost aquifer's effective porosity, bydraulic conductivity and hydraulic gradient, and the fate and transport characteristics of the potential contaminants; or

(ii) An alternates sempling procedure proposed by the owner or operator wod approved by the departument:

\section{FACILITY REQUIREMENT SOURCE; WAC-173-303(931208) Section 645( 8)(h)}

(b) Tho owner or operator will specify ons of the following statistical metbods to be used in

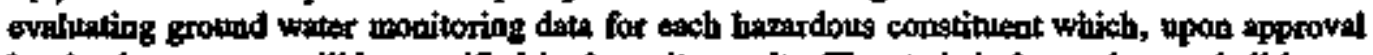
by the department, will be specified in the unit permit. The statistical tese chosen shall be conducted beparately for each dangerous constituent in each well. Whero practical quadification limits (pql's) are used in any of the following statistical procedures to comply with (i)(v) of this subsection, the pql must be proposed by the owner or operator and approved by the department. Use of any of the following statistical methods must be protective of human health and the environment and must comply with the performance standarta outlined in (0) of this subsection."

FACIIITY REQUTREMENT SOURCE: WAC-173-303(931208) Section 645( 8)(1) 


\section{STANDARDS REQUIREMENTS DENITICATION DOCUMENT HIGH LEVEL WASTE STORAGE TANK FARMS \\ Environmental Protection \\ WhC-ER-0750}

"(i) A parametric analysis of variance (ANOVA) followed by multiple comparisone procedures to identify statistically sigrificant evidence of contarnination. The method musst incinde eftionation and testing of the contrasta between each compliance well's mean and the herckground meen levels for each constituent.

(ii) An enalysis of veriance (ANOVA) based on ranks followed by maltiple comparisons procedures to identify statisticelly significent evidences of contimination. The method must irclude estimation nind testiog of the contrasts between each compliance well's median and the backgroumd medion levels for each constitutent.

(iii) A wlerance or prediction interval procecture in witich an interval for each constituent is exteblished from the distribution of the backeround dath, and the level of exch constitutent in

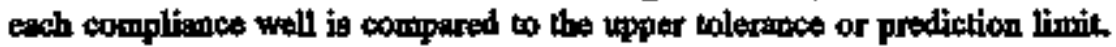

(iv) A control chart approweh that gives controi linits for each constitueot (v) Antother statistical test method salumitted by the owner or operator and ipproved by the depkrtment. (i) Any statistical method chosen tuder (h) of this sulbsection for specifiestion in the unit permit shatl comply with the following performence statands, os appropriate:

(i) The statietical method used to ovaluate ground water monitoring data shall be appropriats for the distribution of chemisal parzunters or dangerous constiments. If the distritution of the chenical parameters or dangenous constituents is shown by the owner or operator to be inappropriate for a normal theory test, then the data should be transformed or a distribution-free theory test should be used. If the distributions for the constituents differ, more than ane statistical method may be needed. (ii) If an intividual well comperison procedure is used to compare an individual compliance well constituent concentration with background constituent concentrations or a groind water protection standard, tho test shall bo done wa Type I ervor level no less than 0.01 for each testing period. If a multiplo comperisons procedure is used, the Type I experiment wise error tate for each testing period shall be no kess than 0.05; bowever, the Type I eror of no less then 0.01 for individual well

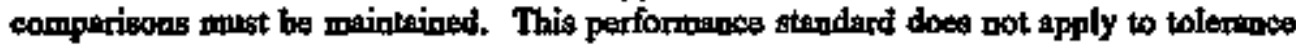
intervals, prediction intervals, of control charts.

(iii) If a control chert approach is used to evaluato ground water monitoring data, the speciis type of control chart and ito associated parameter valnes shall be proposed by the owner or operator and approved by the department if it is protetive of bumgn benith and the environment.

(iv) If a tolerance interval or a prediction interval is ussed to evaluate ground water monitoring data, the lovels of confidence and, for tolerance intervals, the percentage of the population that the interval wust contrin, shell be proposed by the owner or eperator and approved by the depertment if it finds these parametars to be protoctive of buman health and the enviromment. These perameters will be determined after considering the number of samples in the background date bese, the data distribution, and the range of the concentration values for each constituent of concem. (v) The statistical method shall account for daka below the limit of detection with one or more statistical procedines that are protective of human health and the environment. Any practical quantifiention limit (pql) approved by the department under (h) of this subsection thint is used in the statistical metbod shall be the fowess consentration lavel that can be reliably actieved within specified litmits of prestsion and acturacy during routing laboratory operatiog conditions thet are wailable to the fuciltity. (vi) If accessary, the statistical method shatl include procedurea to control or correct for seasonal and spatiol variability as well as tomporal corretation in the dabe"

\section{FACILITY REQUIREMENT SOURCE: WAC-173-303(931208) Section 645( 8)(0)}

"(j) Ground water monitoring data collected in accondance with (g) of this subsection inciuding actual levels of constitueats mast bo maintained in the fecility operating record. The departuent will specify in the permit when the date must be submitted for toview." 


\section{STANDARDS REQUIREMENTS IDENTIFICATION DOCUMENT HIGH LEVEL WASTE STORAGE TANK FARMS \\ Environmental Protection \\ whe- Ep-0350}

\section{FACILIIY REQUIREMLNT SOURCE: WAC-173-303(931206) Section 645(9)(a)}

"(9) Detectica monitoring program. An owner or operator required to establish a detection monitoring prognm under thil subsection must, at a minimum, discharge the responsibilities described in this sobsection. (s) The owner or operstor must monitor for indicator parameters (e.g., pH, specific conchuctance, total organic carbon (TOC), total organic halogen (TOX), or heavy metals), waste constituents, or resction products that provide a refiable indication of the presence of dengerous constituents in ground water. The department will specify the parmeters or canstituents to be monitored in the frecility permit, after considering the following tictors: (i) The types, quantities, and concentrations of constituents in wastes mongged at the regulated unit;

(it) The mobility, stability, and persisteace of waste constitureats or their reaction products in

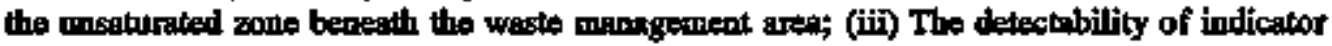
pirsineters, waste coastitureats, and neaction products in ground water; nud"

\section{FACILTY REQURREMENT SOURCE: WAC-173-303931208) Section 64S( 9)(b)}

"(b) The owner of operator must install a groulnd water monitoring system at the complintioe point, as specified under subsection (6) of this section. The ground water monitoring system must comply with subsection (8)(a)(ii), (b), and (c) of this section."

\section{FACILITY REQUIREMENT SOURCE: WAC-173-303(931208) Section 645( 9)(c)}

"(c) Tho owner of operator must conduct a ground water monitoring program for wach chemical parameter and dangerous constituent specified in the permit pursuant to (a) of this

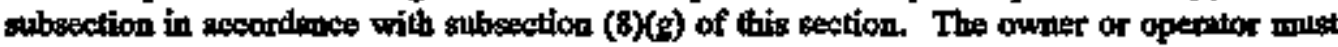
mintintain a record of ground witer wallytical data as measured and in a form necessiny for the determination of stetistical significance under subsection (g)(b) of this section."

\section{FACILITY REQUIREMENT SOURCE: WAC-173-343(931208) Section 645(9)(d)}

(d) The department will specify the frequencies for collecting somples and conduting statistical tests to determine whether there is statistically siguificant evidence of contmination for any parnmeter or dengerous constifuent specified in the permit under (a) of this subsection

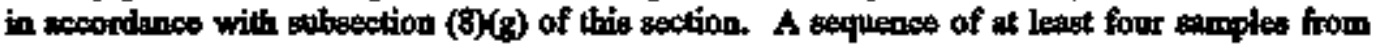
coch well (background and compliance wells) must be colfected at least semianoully during detection monituring."

\section{FACILIYY REQUIREMENT SOURCE; WAC-173-303(931209) Section 645(9)(e)}

"(o) The owner or operator must determing the groutad water flow rate and direction in the uppermost aquifer at least ampuntly.

\section{FACILITY REQUIREMENT SOURCE: WAC-173-303931208) Section 645( 9)(0)}

"(f) The owner of operator mast determine whether there is statistically significant evidence of contamination for any chemical perameter of dangerous constituent specified in the permit pursuent to (a) of this subsection at a frequency specified under (d) of this subsection.

(i) In determining whether statistically significant evidence of contomination exists, the owner or operstor must use the method(s) specified in the permit under suhsection (B)(b) of this section. These method( $(s)$ muat compare data collected at the compliance point(s) to the 


\section{STANDARDS REQUIREMENTS IDENTIFICATION DOCUMENT HIGH LEVEL WASTE STORAGE TANK FARMS \\ Environmental Protection \\ WHC-ER-0750}

becleground ground water quality data.

(ii) The owner or operator must determine whether there is stitistically bitanificant evidence of contminination at each menitoring well as the complimose point within a reasonable period of time after completion of sumpling. The department will spexify in the facility permit whot period of timo is reasonslote after considering the complexity of the statistical test and the

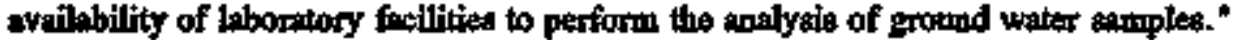

\section{FACILITY REQUIREMIENT SOURCE: WAC-173-303(931208) Section 645( 9)(g)}

"(g) If the owner or operator determines ptirsugat to (f) of this subsection that there is

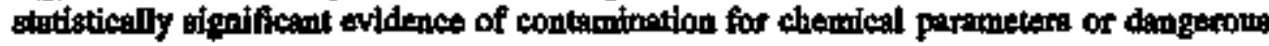
constituents epectifed purguant to (a) of this gubsection at any mostitoring weil at the compliance point, the of ste wust:

(i) Notify the defpartment of this foring in writing within seven days. The notification must indicate what chemical parameters or dangerous constinuents have sbown stitisticolly siprificant avidence of contamination: (it) Immedtately somple the ground water in all mortitoring wetlls and determine whether constiments in the list of Appendix IX of Part 264 are present, ind if 80, in what concentration.

(iii) For any Appendix $X$ compounds found in the ansiysts pursuent to (g)(ii) of this subection, twe ovener or operator may resomple within one month and nepeot the analyais for thoes compoundi detected. If the results of the second analysis confirm the initial resolts, then these constituents will form the basis for compliance monitoning. If the owner or operator does not reserriple for the compotudg found pursurnot to (g)(ii) of this subsection, the dengenous constituents fourd during this initial Appendix IX analysis will form the basis for compliance monitoring.

(iv) Within ninety deyb, submit to the depertmeat an application for a permit modification to establish a compliance monitoring program meeting the requirements of subsection (10) of this section. The application mnst include the following information:

(A) An identification of the concentration or any Appendix $\mathrm{XX}$ constituent detected in the ground water at each monitoring well at the compliance point; (B) Any proposed changes to the ground water monitoring system at the facility necessary to meet the requirements of gulusection (10) of this section;

(C) Any proposed additions or changes to the monitoring frequency, sampling and analysts procedures or methods, or statistical methods used at the facility necessary to meet the requirements of subsection (10) of this section;

(D) For each dangerous constitueat detected at the compliance point, a proposed concentrotion

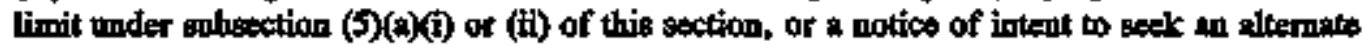
concentration limit under subsection (5)(b) of this section; and

(v) Within one buodred eighty days, subomit to the departonent: (A) All data necesenry on justify an alternato concedtration limit sougint tonder subsection (5)(b) of titis section; and

(B) An enginesing fesibility plan for a corrective action program necessiny to meet the

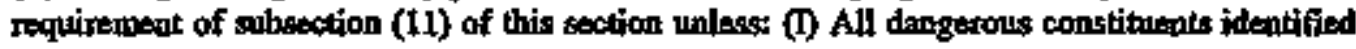
under (g)(ii) of this subsection are listed in Table I of subsection (5) of this section and their concentrations do not exceed the respective values given in that Table; or (II) Ths owner or operator has sought an alternate concentration limit tuder subsection (5)(b) of this section for

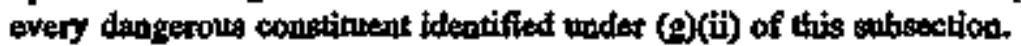

(vi) If the owner or operotor determines, plissuaut to ( $f$ ) of this sulusection, that thene is a statistically significant difference for chemical parameters of dangercus constituenta specified pursuint to ( $\theta$ ) of this subsection at any monitoring well at the compliance point, he of she miny denoonstrate that a sontos other than a regulated unit censed the contamination to thet the detection is on artifact caused by an trror in sempling, anolysis, or statistical evaluation or notural variation in the growed trater. The owner operalar may make a demanstration under 


\section{STANDARDS REQUIREMENTS IDENTIFICATION DOCUMENT HIGH LEVEL WASTE STORAGE TANK FARMS \\ Environmental Protection \\ WHC-EPRTSO}

this subsextion in addition to, or in lieu of, submitting a permit modification application under (g)(iv) of this subsection; however, the owner or operator is not relieved of the requirament to sobmit a permit modification appliantion within the tims specified in (g)(iv) of this subsection unless ofs demongtrition made ander this gnhsection suctessfully shows that a source other

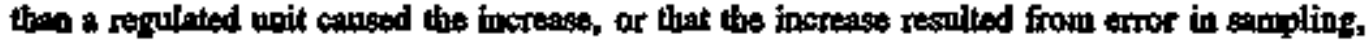
anslyeis, or evaluetion. In making a demmstration under this subsection, the owner or oparator mont:

(A) Notify the department in writing within seven days of determining statistically signifieant evideace of contamination at tho complianco point that he intends to make a demonstration under this subsection; (B) Within ninety days, submit a report to the department which desnonstrates that a source other than a regulated unit caused the contaunination or that the contamination resaltad from enror in sanpling, endysis, or evaluation; (C) Within ninety disy, salbmit to the department an application for a permit modification to make any appropriate changes to the detection monitoring program facility; and

(D) Continue io monitor in accordance with the detection monitoring program established under this section."

\section{FACILITY REQUIREMENT SOURCE: WAC-173-303(931208) Section 645( 9)(h)}

(b) If the owner or operator determines that the detection monitoring program no longer gatisfies the requirements of this section, he or she must, within ninety days, submit an applikation for a permit modification to make any appropriate changes to the program.

\section{FACILTY REQUREMENT SOURCE: WAC-173-303(931208) Section 645(10)(a)}

(10) Campliance moattoring program. An owner or operator requited to establish a compliance monitoring program under this section must, at a mininmm, discherge the responsibilities described in this subsection. (a) The owner or operator must monitor the ground whter to determine whether reptulated tmits ars in compliance with the ground water protection standard under subsection (3) of this section. The department will specify the ground water protection standard in the fatity permit, fnchuding (i) $A$ list of the dangerous constituents and parameters identified under subsection (4) of this section;

(ii) Concentretion limits under subsection ( $(5)$ of this settion for each of those dangerous constituents and parameters;"

FACILITY REQUIREMENT SOURCE: WAC-173-393(931208) Section 645(10)(b)

(b) The owner or operator must install a ground water monitoring system at the compliance point as specified under subsection (6) of this tion. The groutud water monitoring system must comply with subection (8)(a)(ii), (b), and (o) of this section."

\section{FACILITY REQUIREMENT SOURCE: WAC-173-303(931208) Section 645(10)(c)}

(c) Tho department will specify the sampling procedures and statistical methods appropriate for the constituents and the facility, consistent with subsection (g) (a) and (b) of this section. (i) The owner or operator must conduct a samping program for eacti cbemical paranteter or dangerous constituert in accordance with subsection (8) (g) of this section.

(ii) The owner or operator must recond ground water analytical date as measured and in form neceseary for the determination of statistical significance under subsection (8)(h) of this section 


\section{STANDARDS REQUIREMENTS IDENTIFICATION DOCUMENT HIGH LEVEL WASTE STORAGE TANK FARMS \\ Environmental Protection \\ whC. Bp-onso}

for the complience period of the facility."

\section{FACTITY REQUIREMFNT SOURCR: WAC-173-303(931208) Section 645(10)(d)}

(d) The owner or oparator mast determine whether there is shatistically significant evidance of

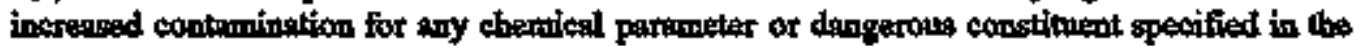

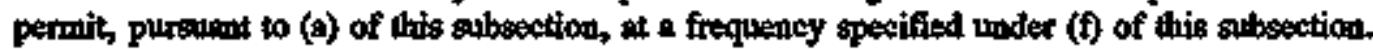
(i) In deterrining whether statstically sionificast evidente of increased contumination exises, the owner or operetor mast use the method(s) qpecified in the prenit under sulbection (8)(h) of this section. The method(s) mugt compere date colleoted at the campliance poitut(s) to a concentration limit developed in accordance with enbsection (5) of this section. (ii) The owner or operator mnst determine whether there is statirtically significant evidence of inereased contemivation at esch monitoring well at the compliance point within a reasonable tims pariod after conmpletion of sampling. The departmeat will specify that time period in the ficility permit, after considering the complexity of the statistical test and the avaliability of laboratory facilities to perform the analysin of ground water samples."

\section{FACILITY REQUHREMENT SOURCE: WAC-173-303(931208) Section 645(10)(e)}

"(e) The owner or operator mast determine the rate and direction of ground water fiow in the nppermose aquifer at least anmually."

\section{FACAITY REQUTRDMENT SOURCE: WAC-173-303(931208) Section 645(10)(t)}

"(f) The departement will specify the frequenties for collocing samples end conducting

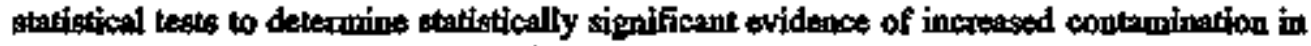
accordauce with subsection (8)(g) of this section. A sequence of at keast four samples from each well (beckground and compliance wells) must be collected et least semiannuelly during the compliance period of the facility."

\section{FACIIITY REQUIREMANT SOURCE: WAC-173-303(931208) Section 645(10)(g)}

"(g) The owner or operator must anglyzs samplea from all monitoring wells at the compliance point for an constituents contained in Appendix XX of Part 264 at least ammuslly to detarmins whether additionel dingeroul constituents arro present in the uppermost squifer and, if 80 , at whet concentrition, pursuant to procedures in (f) of this subsection. If the owner or operator finds Appendix IX constitments in the sround water that are not slready identified in the permit as monitoring constifutents, the owner or operator may resample within one month and repeat the Appendix XX malysis. If the second anslysis confins the presencs of new constiturents, the owner or operitor must ieport the concentration of dhese additional constituents to the department within seven days after the completion of the second anslysis and add them to the monitoring list. If the owner or operator chooses not to resample, then he or she must report the concentrations of these additional constitcents to the department within seren dsyb after completion of the initial andysis and add them to the monitoring list. If the owner or operator determines, pursuant to (d) of this sulseetion, that eny concentration limits under subsection $(J)$ of this bection are being exceeded at any monitoring well at the point of compliancs, he must:

(i) Notify the department of this funding in witing within seven days. The notification must 


\section{STANDARDS REOULREMENTS IDENTIFICATION DOCUMENT HGH LEVE, WASTE STORAGE TANK FARMS \\ Environmental Protection \\ WEC-ROTSO}

indicents what coscentrition lineits hove been exceeded; (ii) Stubmit to the department an application for a permit modification to establish a contective antion program meeting the requitements of solbsetion (11) of this section, within ninety days, or within sixty days if an enginearing feasibility study hes been previously submitted to the department tmed subsextion (9)(h)(v) of this section. For regulated units manging EHW, timo frames of sixty doys and forty-five drya, respectively will apply. Howover, if the department finds that the full extent of the ninetylaixty-dey of the sixty/forty-five-day time periods will inctease the likelihoed to cousse a threat to public health, of the enviromment, if can at its discretion retiuse their durotion. In specifying shorter limits, the department will consider the following factores (A) The physical and chemicel characteristics of the dengerous conetituentr and perameters in the ground wateri

(B) The hydrogeologieal characteristics of the facility and of the surrounding hand;

(C) The rate of movement and direction of flow of the affected ground water; (D) The proximity to and withdrawal rates of ground water users downgradient; and

(E) The current and future uses of ground water in the concermed area; nad (iii) The application molst at a minimum tirclude the following information: (A) A detailed description of corrective action that wilk schieve compliance with the ground water protection standard specified in the permit; and (B) A plan for a ground water monitoring progrem that wit demonstrate the effectiveness of the corractive action."

\section{FACILITY REQUIREMENT SOURCE; WAC-173-303(931208) Section 645(10)(i)}

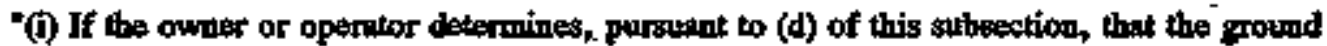
Watror consentration timita uador this ection are being exceeded at any monitoring well at the point of conpliance, he may demoonstrats that 2 source other than a regulated rooit caused the contannination of thet the detection is an artifint caused by au error in sampling, analyata, of statietical oveluation or natural veriation in the grousd water. In making a dewernstration uniler this gubsection, the owper or operation mitst:

(i) Notify the departanent in writing within seven days that he intends to maks of demonstation under this sulbsection;

(ii) Within forty-fivo daya, gubmit a report to the departmest which derronstrete that a sourse other than a regulated unit cetused the standird to be exceeded or that the apparent. notcomplianse with the stonderds resulted from error in setroling, antysis, or evaluation; (iii) Within forty-five days, mibmit to tho department an application for a perrit modification to make appropriate changes to the compliance monitoring program at tho facility and (iv) Continus to monitor in socord with the compliance monitoring program established onder this section."

\section{FACILFY REQUIREMENT SOURCE; WAC-173-303(931298) Section 645(10)(j)}

"(j) If the owner or operator determines that the complimace monitoring program no longer sutisfies the requirements of this section, be must, within forty-five days, submit an application for a permit modification to make moy appropriate changes to the program."

\section{Air Ouality}

This aubelement apecifies the requirements for monitoring of air quality. Technical guidance is provided in DOEEEH-0173T. Tank Farms currently inclutes 8 tanks listed as contonining greater than or equal to 10 weight percent (dry hasis) organics expressed as sodium scetale with a ninth tank recommended to be added to the list Therefore, the tequirements of $40 \mathrm{CFR}$ 


\section{STANDARDS REQUIREMENTS IDENTIFICATION DOCUMENT BIGH LEVEL WASTE STORAGE TANK FARMS \\ Environmental Protection \\ WHCEP.0750}

Subpart BE, "Air Emission Standardi for Equipurent Lesaks" applites to these tanks. The footnote for the wond "should" in thil document indicates performance eriteria and procedines rexpired to operate and maintain $\backsim$ acceptable radiation protection program for the public and the exvinonment.

\section{FACILITY REOUIREMENT SOURCE; 40CFR265 Part 1052}

Strmatards: Pumpe in light liquid servica.

(o)(1) Each purip in light liquid services shall be monitored mouthly to detect leaks by the medrods epecified in 265.1063(b), except otovided in preagraphs (d), (e), end (f) of this section.

(2) Each pump in light liquid service stall be chected by visual mspection esch calendar watk for mdicstions of liquids driping from the pump seal.

(b)(1) If an instrument reafing of 10,000 ppim or greater is measured, a leak in detected.

(2) If there ane indications of tignids dripping from the permp seal, a lesk is detected.

(c)(1) When a kelk in detected, it fhall be repaired as soon as practicable, but not later then 15 calendar days after it is detected, except an provided in 265.1059 .

(2) A hist attempt at repair (e.g. tightening the packing gland) shall be made no later than 5 colteudar days after each leak ia detected.

(d) Ench pump equipped with a dual mechanical seal system that includes a barrier fluid gystem is exempt from the requirements of paragraph (a) of this section provided, the following requiremeats arp wet:

(1) Eech dual mechanical seal system must bet

(i) Operated with the barrier fluid at a pressure that in at all times greater than the pump shuffing box pressure, or

(ii) Equipped with a barrier fiuid degassing reservoir that is connected by a closed-vent system to a control device that complies with the requirements of 265.1060 , or

(iii) Equipped wilh a gystem that purges the barrier fituid into a harardons waste atream with no detectable enissiong to the atmosphers.

(2) The barrier fhuid system most not be a hamadous waste with organic concentrationa 10 percent or griater by weight.

(3) Eech barrier fiuid system nutst be equjpped with a sensor that will detect failure of the seal system, the barrier fluid system, or both.

(4) Eoch pump must be checked by visual inspection, each celendar week, for indications of lituids dripping from the pump seals.

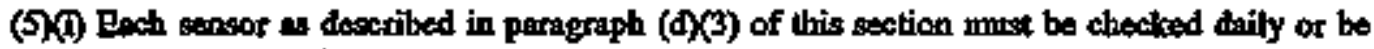
equipped with an audible alarm that must bo checked monthly to ensure thet it is functioning properly.

(ii) The owner or operator mast determine, based on design considerations and operating experience, a criterion thet inticates trithre of the beal system, the barrier fluid sybtem, or both.

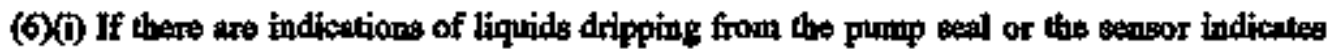




\section{STANDARDS REQUIREMENTS IDENTIICATION DOCUMENT HIGH LEVEL WASTE STORAGE TANK FARMS \\ Environwental Protection \\ WHC-EPQO750}

finlure of the seal system, the barier flutd zyttem, of both based on the criterion determined in prorigraph (d)(5)(it) of this section, a kat is detected.

(ii) When a leak is detected, it shall be repairad as soon as prosticable, but not gregter than 15 celendar days ater it is detected, except as provided in 265.1059 .

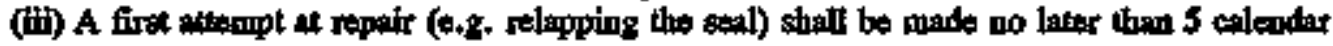
days after ench kell is detected.

(e) Any pump that is desigatated, as described in $265.1064(\mathrm{~g})$ (2), for no detectable emissions, ag iscicated by an instrument reating of less then 500 ppm abovo backgroutud, is axempt from the requirements of paragriphe (s), (c), and (c) of this section if the pamp meets the following requirentents:

(1) Must have no exteraslly actuated shaft penetrating the purop housing.

(2) Must operits with wo detecteble emissions as indicated by an instrument reading of lesa then $500 \mathrm{Fpm}$ above beckground at measined by the mothods specified in 265.1063 (c).

(3) Must be tested for compliense with paragraph (e)(2) of this section initially upon desigration, annually, and at other times as requested by the Regional Administrator.

(t) If any pruxp is equipped with a closed-vent system cappable of cepturing and thinsporting any leaknge from the seal or seols to a control devioe that complises with the requirements of 265.1060, it is exempt from the requirements of paragraphs (a) through (e) of this section.

\section{PACHITY REQUIREMENT SOURCE: 40CRR265 Part 1054}

\section{"Standarda: Pressure Relief Devices in Gas Vapor Service}

(B) Except during pressure releases, each pressure relief device in gas/vapor service shall be Opensted with no detecteble emissions, as indicated by an instrument resitivg of less than 500 ppm above beckgrount, as measured by the method specified in 265.1063(c).

(b)(1) After ech pressure retease, the pressure relief device shall be refmrned to a condition of no detecteble omiesions, as indicated by as instrument reading of less than $500 \mathrm{pmm}$ above background, as soon as procticable, but no later than 5 calendar days after each pressurs xelease, excepk as provided in 265.1059 .

(2) No tater then 5 calendar deys after the pressure release, the pressure relief device shall bo monitored to coofirm the condition of no detectable emissions, as indicated by an instrumeat reading of less than $500 \mathrm{ppm}$ above background, as measured by the method specified in 265.1063(c).

(c) Any pressure relief device that is exuipped with a closed- veat system capable of copturing and transporting leakge for the pressure nelief device to a control device as described in 265.1060 is exempt from the requirements of paragraphs (a) and (b) of this section."

\section{FACIITY REQUREMMONT SOURCE: 40CFR265 Part 1055}

"Shotarils: Sompling Connecting Systems

(a) Eech sampling conmection system shall be equipped with a closed-purge syotem or 


\section{STANDARDS REQUIREMENTS IDENTIFICATION DOCUMENT \\ HIGH LEVEL WASTE STORAGE TANK FARMS \\ Environmental Protection \\ wro-ER-OTSO}

closed-vent system.

(b) Each closed-purge or closed-vent ajstem as required in paragraph (a) shall:

(1) Retum the purged herardons wasto stream directly to the hazardoun waste management process line with no detectable emissions to the atmosphere, or

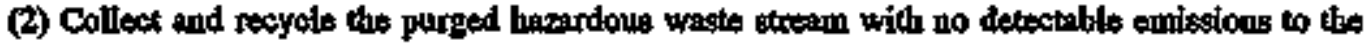
imoeplatere, or

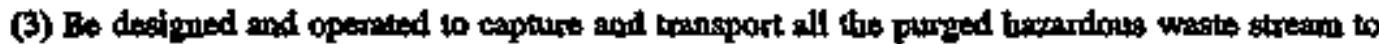
a control device that conoplies with the requirempents of 265.1060 .

(c) In situ sampling systems aro exempt from the requirtements of paragraphs (a) and (b) of this section."

\section{FACILITY REQURRMENT SOURCE: 40CFR265 Part 1057}

"Staodarder Vatves in Gos/Vipor Service of in Light Liquid Service

(a) Fech volvo in gas/vapor service of light liquid service shall be monitored monthly to detect leaks by the methods specified in 265.1063 (b) and stall comply with paragraphs (b) throngh (e) of this section, except as provided in paragraphs (f), (g), and (h) of this section' and 265.1061 and 265.1062 .

(b) If an instrument readiog of 10,000 ppm or greater is messured, a leak is detected.

(c)K1) Any yalve for which a leak is not detected for two successive montles misy be monitored the first month of every succeding querter, beginning with the dext querter, tutil a leats is detected.

(2) If a leak is detected, the valve shall be monitored monthly until a leak is not detected for 2 successive months.

(d)(t) When a leak is detected, it shall be repaired as soon as practiceble, but no later than is calendar dayn after ths lest is detected, except as provided in 265.1059 .

(2) A first attempt at reppir shat be mode no later than 5 calendar days after the leak is detected.

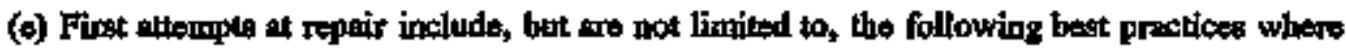
practicables:

(1) Tightsoning of bonnet bolts.

(2) Replecement of bonnet bolts.

(3) Tightening of pacting gland muts.

(4) Injection of lobricant into lubrieant pacibing.

(i) Any valve that is designated, as described in 265.1064 (g)(2), for no detectable emiseions, as indicated by an instrument reading of less than $500 \mathrm{ppm}$ above background, is exempt from the recuirements of paragraph (a) of this section if the valves 


\section{STANDARDS REQUIREMENTS IENTIFICATION DOCUMENT FIGH LEVEL WASTE STORAGE TANK FARMS \\ Environmental Protection \\ WHC-EP-0750}

(1) Has no external actuating mechanism in contact with the haxardous waste stream.

(2) Is opernted with emissions less than 500 ppm above backgroumd as determined by the method specified in 265.1063(c).

(3) Is tested for complismce with paragraph (f)(2) of this section initially upon designetion, anctilly, and at other times as requested by the Regional Administrator.

(g) Any valve that is designated, is described in 265.1064(b)(1), as an unsafe-to-nnonitor valve is exempt from the requiremente of paragraph (a) of this section if

(1) The owner or operator of the valve determines that the valve is unsafo to monitor becmse monitoring persomel thould be exposed to an immediste danger as a comsexpence of complying with paragraph (a) of this section.

(2) The owner or operator of the valvs adberes to a written plan that requires monitoring of the valve as frequeatly as procticable during sato-to-monitor times.

(h) Any valve that is desigated, a described in $265.1064(h)$ (2), as a difficult-to-monitor valve is exempt from the requirements of paragraph (a) of this section if:

(1) The owner or operator of the valve determintes that the valve cennnot be monitored without eleveting the manitoring personnel more than 2 meters above 2 support surface.

(2) The haxardous waste management unit within which the valve is located wes in operation before June 21, 1990.

(3) The owner or operator of the valve follows a witten plan that requires monitoring of the velve at least ance per calendar year."

\section{FACILITY REQUIREMENT SOURCE; 40CFR265 Part 1058}

"Stenderda: Pumps and Valves in Heavy Liquid Service, Pressure Relief Devices in Light Liquid or Heavy Liquid Service, and Flanges end Other Connectors

(a) Pumps and valves in heavy liquid service, pressure relief devices in light liquid or hevy liquid service, and flanges and other connectors shall bo monitored with 5 days by the method specified in 265.1063(b) if evidenoce of a potential leat is found by visual, audible, olfactory, of sny other delection mathod.

(b) If an instrument reading of 10,000 ppm or greater is messured, a leak is detected.

(c) When a leak is detected, it shall be repaired as soon practicable, but not later than 15 calendar doyg after it is detected, arcept as provided in 265.1059 .

(2) The first aftempt at repair shall be made no later than 5 colendar days ofter each leal is detocted.

(d) First attempts at repair include, but are not limited to, the best practices deseribed under $265.1057(\mathrm{e})$.

FACIITTY REQUTREMENT SOURCE: 40CFR265 Part 1059

"Stardiardst Delay of Repair 


\section{STANDARDS REQUIREMENTS IDENTIFICATION DOCUMENT HIGH LEVEL WASTE STORAGE TANK FARMS \\ Environmental Protection \\ WHC-EPOTSO}

(a) Delay of repair of equipment for which leaks hayo bees detected will be allowed if the repair in bectnically infeasible without a harandours waste managensent tunit shutdown. In such

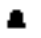
case, repair of this equipment sthil oceur before the end of the next hacardous waste manngement mit stutdown.

(b) Delsy of repair of equipment for which leeks bave been detected will be ailowed for equipment that is ioolnted from the hazorlous thaste management trit and that doee not continue to contain or confact hurardous vasts with orgemic concentrations at least 10 percent by weight.

(c) Delay of repuis for valves will be dlowed if

(1) The owner or operator detertwines that extissions of purged material resultiog from

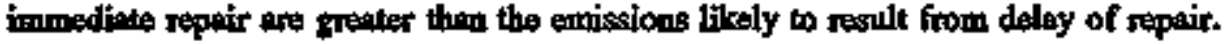

(2) When repair procediures are effected, the puryed matstial is collected and destroyed or recovered in 4 control devive complying with 265.1060.

(d) Delay of repair for pumps will be allowed if:

(1) Repair recquires the use of a dual mechanicel seal system that inclndes n barrier fluid system.

(2) Repair is completed as soon as practicable, but not latter than 6 months after tho leak was detectod.

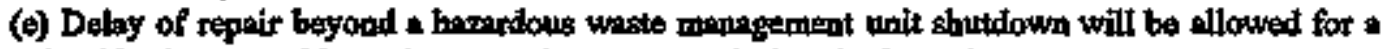
valve if valvo aesembly replacement is necessery during the hazerdous waste moungement. unit ahutdown, velvo assembly aupplies have beed depleted, and valve aseambily suppliea had been sufficiently stocked before the sopplies wero depleted. Delay of repair beyood the next harrandous waste management unit ahutdown will not be allowed unlesa the next hazandous wasto management shutdown oceura soomer than 6 months after the first hazardous waste manegearenk ninit shutdown."

\section{FACILITY REQUIREMTRT SOURCE: DOEAEH0173T Section 3.1, Paragraph 1, Sentences 2-4}

The cojterie listed in Table 3-1 <DOEVEH-0173T> art based on the projected effective doso equivilent in one year to a metnber of the pubtic (in rem). Additional airtionds emiseion requirements for DOE-controlled facilities that aro requited under DOE 5400.1 and DOE 5400.5 ane given in the aummary end disenssed in this chipter. The mouttoring effort should be conrmensurate with the inportance of the sources during routine operation and from poteatial aceidents with respect to their potential contribution to public dose or to contamination of the exvironment."

\section{FACILITY REQUIREMIENT SOURCE: DOEJGT0173T Section 3.3, Sentences 1-4}

"The frequency requirements for sirbome emission monitoring (continguos monitoring andor ampling) programs tre sumurizized in Tyhle 3-1. Application of these criterit to an individual fartility (DOF-controlled sits) of soures (DOE-controlled facility) requites that an

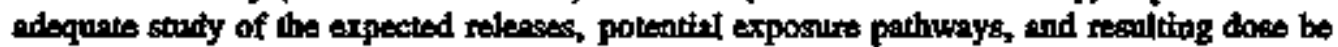
conducted. For all new facilities of facilities that have been modified in a manner that could affect effiuent release quantity or quality or that could affect the sensitivity of monitoring of 


\section{STANDARDS REQUIREMENTS IDENTIFICATION DOCUMENT FIGH LEVEL WASTE STORAGE TANK FARMS \\ Environmental Protection \\ WHC-EP-0TSO}

arveillance sysiems, a precperational assessment $\langle>$ be made and dounmented in the site Environmental Moritoring Plan to determins the types and anontities of iirtorne trristions to be expected from the facility, and to establish tho stseciated tirtome gurisston monitoring nesds of the facility. The performence of the airbons emissions monitoring systems should be arficient for determining whether the raleases of radicactive materiale are wiltin the limits or requinemente specified in DOE 5400.5."

\section{FACILITY REQUIREMENT SOURCE; DOE5400.1 Chapter IV, Section 8.h(I)}

"Air Monitoring - Enviranmedtal Surveillinneo

(1) Ambient it quality monitoring progrants should bo designed to menplith the following:

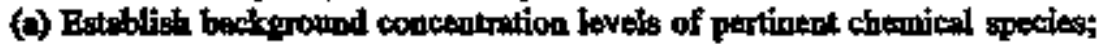

(b) Determino the highest conceatritions of the pertingut pollutant species expected to oceur in the vicinity of DOE operations;

(c) Detersing representativo pollutant concentrations at areas where public heolth and ofter concerns sloonid bo constident; and

(d) Eveluots the effecta of eprissions on ambieat levels of pertinent contaminants,"

\section{FACILITY REQJIREMENT SOURCE; WAC-2A6-247(940131) Section 080( 1)}

The depertment reserves the right to inspect and audit all construetion ectivities, equipment, operetions, documerts, dote, and other records related to compliance with the requinements of this chapter. The department may require a demonstration of ALARACT at any timo."

FACILTY REQUIREMINT SOURCE: WAC-246-247(940131) Section 080( 2)

-All reporting and recordkeeping requirements of 40 CFR 61, subparts $H$ and I pablished in the Foderal Register on December 15, 1989, are adopted by reference, as appliceble as specified by the refenance subparts."

\section{FACITITY REQUREMENT SOURCE: WAC-246-247(940131) Section 080( 9)}

The facility shall ensure all emission units are fully accessible to departusent inspectora. It the ovent tho havard associated with acoessibility to $\mathrm{a}$ unit repuine training and/or restrictions or requirements for entry, the fecility ovner and operator shall inform the depertment, ptior to urival, to those restiotions of requiremeate. The owner or cperator shall be responsible for providing the neceseary thining escotts, and expport services to illow the deportinent to inspeat the fecility."

\section{FACILITY REQULRFMENT SOURCE: WAC-246-247(940131) Section 080(10)}

"The facility siall mike available, in a timely masner, all documents requested by the department for review. The fucility shall allow the department to review documents in advance of an inspection. The facility shall aliow access to classified documents by representativas of the department with the appropriate security clearances and demonstrablo need-tolnow." 


\section{STANDARDS REQUIREMENTS IDENTIFICATION DOCUMENT GIGH LEVEL WASTE STORAGE TANK FARMS \\ Environmental Protection \\ WHC-EPR-0750}

\section{FACIITY REQUIREMENT SOURCE: WAC-246-247(940131) Section 080(t1)}

The freility sholl respoed in writing in a timely manoer, or within a time limit set by the depertment. The inspection results with tequire the facility to inplement corrective netions or siny other wetions solinected by the department."

\section{Fongrdoun Matgrigls}

This subelement provides requirsments for a hazartous materials management program thet provides for compliande with provistong of SARA Titte III, EMERGENCY PLANNING AND COMMUNITY RTGHT-TO-KNOW regulstions regarding hazandous and toxic chemieals, and regulations rogarding the manghement of RCRA hazardoos traster. In nddition, requirements for moniforing hatordous material relasses from Underground Storage Tanks storing diesel fuel, and monitoring of surfice impoundment liners for the LERF are provided.

\section{FACILITY REQUIREMENT SOURCE: WAC-173-360 Section 350(2)(b)}

\section{Methods of Release Detection for Piping}

Suction piping. Undergromud piping that conveya regalated substances under suction sinoll oither have a line tightness test conducted at lenst every three years and in accondence with subsection (3)(b) of this section, or tuse a moathly monitoriag method condacted it accordance vith subsection (3)(c) of this section. No ralease detection is toquined for suction piping that is destigned and constructed to meet the following standards:

(i) The below-grade piping operates at les than atemospheric pressure;

(ii) The below-ande piping is sloped so that the contents of the pipe will dratn back thto the atrorace tonk if the metion is releosed;

(iii) Only ons check valve is incluted in each stration tines

(iv) The chect valve is located below and as close as practicel to the saction pump; and

(v) A method is provided that allows compitinces with gubsection (2)(b)(ii) through (iv) of this section to be readily determined."

\section{FACILITY REQUIREMINT SOURCE: WAC-173-360 Section 350(3)}

"Methodg of Release Detection for Piping

Each mothod of release detetion for piping resed to meet the requirementh of WAC 173-360-335 shall be conducted in eccordance with the following:

(a) Automatic line leste detectors. Methods which alert the operator to the prosence of a leat by restricting or shutting off the flow of regulated substances through piping or triggering in audible or visual alarm may be tused only if they detect kaks of thres gellons per hour at ten pounds per square inch line pressure within one hour.An anmul test of the operation of the leak detector shill be conducted in accordnmee with the munufacturer's requirements.

(b) Line tightness asting. A periodic test of piping migy be conducted only if it cen detect 0.1 


\section{STANDARDS REQUIREMENTS IENTHICATION DOCUMENT HIGH LEVEL WASTE STORAGE TANK FARMS \\ Environmental Protection \\ WHC-EP-0750}

gallon per hour leak rate af ons and ono-falf times the operating pressure.

(c) Applicoble tank methods. Any of the methods in WAC 173-360-345(6)(f) through (i) may bo used if they are designed to disteet a releass from any portion of the underground piping thet routinely containu regulated substances."

\section{Radiological Emlients}

This aubrelement specified the requirentents for the facility to moritor rectioactive effluents in eit and water modia and to perform an assesement of the potential madiation dose to members of resulting from site operations, Facility design criteria is provided in DOE 6430. IA. The footnote for the wond "hould" in this document indieates performance criteria and procechures required to operate and maintain an scceptable radiation protection progem for the public and the envitoment.

\section{FACHITY REQUREMIENT SOURCE: 40CFR61 Part 93(b)(1) and (2)}

\section{"Emission Monitoring and Test Procedures}

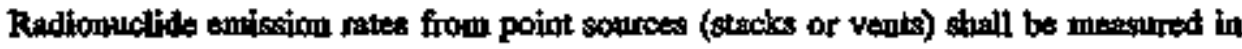
accordance with tho following requirements or other procedures for which EPA has granted prior approval:

(1) Effiuen flow rato measurements shall be made using the following methods:

(j) Reference Method 2 of Appendix A to part 60 shall be used to determins velocity and volumetrio fiow rates for torts and lange vents.

(ii) Reforence Method 2A of Appentix A to part 60 shall bo used to measure flow nates through pipes and small venta.

(iii) The frequency of the flow rate messuremeats shall depend upon the variability of the offluent flow rata. For variable flow rates, contimuous or frequent flow rato measurements shall be mide. For relatively constant flow rates only periodic mearurements ane nocesseary.

(2) Rodionuclides ahall be directly monitored or extracted, collected and measuned using the Following matbods:

(i) Reforence Method I of Appendix A part 60 shall be used to stlect monitoring of sarapling sites.

(ii) The ofthuent stream shall be directly monitored continuously with an in-line detector of representative samples of the effluent stream shall be withdrawn continuously from the sampling site following the guidanoe presented in ANSI N13.1-1969 "Ouide to Sampling Airborne Radiontive Moteriats in Nuclenr Facilitieg" (including the guidanos presented in Appendix A of ANSI N13.1) (incorparted by referedce-see 61.18). The requirements for

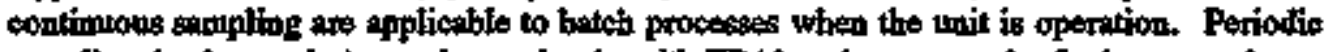

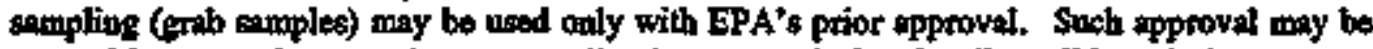

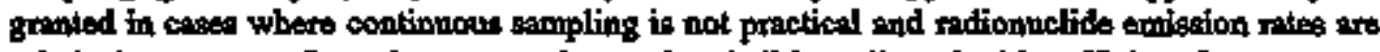
reletively constant. In awh cases, grab earnples slmall be collected with sufficient frequency so as to provide a representative sample of the emissions. 


\section{STANDARDS REQUIREMENTS IDENTIFICATION DOCUMENT FIGH LEVEL WASTE STORAGE TANK FARMS \\ Environmental Protection \\ WHC-EP-0750}

(iii) Redionuclides shall be collected and meosured using procedures based on the principles of messurement described on Appendix B, Method 114. Use of mathods based on principles of tnengurement different from those described in Appendix B, Method 114 must have prior approvel from the Administrator. EPA reserves the right to approve measurement procedures.

(iv) A quality wasurance program shall be conducted that mets the performance requirements deseribed in Appendix B, Method 114."

\section{FACLITY REQUIREMENT SOURCE: 40CFR61 Part 93(b)(4)}

\section{Fintosion Monitoring and Test Procedures}

(i) Radionuclide extission messurements in confommes with the requirements of paragraph (b) of thitis eoction finall be made at all release points whikh have a potential to dischargo radiomeltides into the alr in quantities which could canse an effective dose equivilent in ercess of 1 \% of the standard. An radionuclides which conld contribute greater than $10 \%$ of the potential effective dose expivalent for a release point shall be measured. With prior EPA approval, DOB may determine these emissions through altermative procedures. For other nelease points which have a potential to release rodionuclides into the air, periodic confirmatory messurements etrell be mods to verify the low emissions.

(ii) To determine whether a reitease paint is gubject to the emission measurement requirements of parzoriph (b) of this section, it is necessery to evaluate the potential for radiounclide envissions for that relesse point. In evaluating the pocential of a releese point to discharge madionaclides into the air for the purpose of this section, the estimated radionuclide release rates sholl be based on the discharge of the effinuent stream that would reselt if ell pothution costinol equipment did not exist, hut the facility operations were otherwise normal."

\section{FACEITY REQUIREMENT SOURCE: DOE/EA0173T Section 3.5.8.3}

"The following criteria are guidelines to be considered for monitors that measure specific madionmelides.

Tritium Monitors. ANSI N42.18-1974 (R 1980) specifies a minimum level of detectibility (MID) for tritium of 5E6 micro-Ouries per inL for continnous monitors used in gaseous effluent streams. IEC N.761-5 specifies a mindmum level of detectability of 2E-6 micro-Curies per mL. The ANSI MLD is 21974 minimmm stendard, and is spectifiea ireegurabite cencentrations at a $95 \%$ confidence level after 4 howrs of sample concentration. However, the detectahility lovel may not be obcainable with mixhures of radionuclides, and iustmment response is tirmited by nntural airborne radiosctive materials (radon end thoron in equilibrium with their decay products). Additional concens that should be considered in instrument design for tritium monitors besed on the IEC standard (IEC N.761-S) aro as follow:

Temperature control during sample tramsport to prevent condensation (much of the tritium may be in the form of airbome weter yapor); and

Trapping or retention of water by a filter or sorbent (since mush tritium is commonly in the form of HTO).

Radiviodine Montitars. Iodime cartridges used to collext radioiodine may be monitored at the collection point with a shielded detector, usually a single-channel thellinm activated sodium 


\section{STANDARDS REQUTREMENTS WENTIFICATION DOCUMENT HGH LEVEL WASTE STORAGE TANK FARMS \\ Environmental Protection \\ WEC-EP-0750}

iodide [NaI(T))] detector. Typical systems have coe or more chancoal cartridges in a series, preseded by an absolate particulate filter. In-lins measurements of low consentrations of ratioioine in air witl usually not be fessible becanse of the presence of other mationuclides or radiation fiekts. Iodine cortridgea must be repbeed at least weelly and the meacurements verified by bobartory counting (DOE/EP-0096. Minimam levels of detectsbility for varicas iodine isotopea for continnous monitors of gisevus efftuents mnst be established for a sita, considering state of the art monitoring capebilities. The same genersl specifications given in the preceding discussion of tritiom monitors, based on the IEC standand, should be considesed for ixdirs monitors."

\section{FACILTY REQUIREMENT SOURCE: DOE/EHO173T Section 8.1.1}

The rexuirements to be followed when calculating public radiation dose are lieted in the stummary. DOE projprams for gurfaco- and ground-water monitoring, reporting, and modeling are under consideration by the DOE Office of Environmental Guidance and Compliance; thus, fow detpits on these subjects are provided in this guide. These requirements will be broed enough to define conditions for radionuclides and associated chemicals that could enter surface or grougd waters. Except where mandated otherwise (e.g., somplinose with 40 CFR Part 61), the essesentedt modets aclexted for all enviroumedtal dose assessmeats stould* appropriately characterizs the physical and envirommental siturtion encountered. The inforntition used in dose assesserents abould" be ag acurate and realistic as possible. Complese documentstion of assesenents of the radiation does restilting from the operation of DOE-controlled facilities abould* be provided in a manner that supports the annukal site envirommental monitoring report, Environmentel Monitoring Pim, or other application, and show the 1) madela used, 2) computer progratnd used, and 3) impat data and dem sourcessomptions made."

\section{FACILITY REQUIREMENT SOCJRE: DOES484.1 Chapter II, Section 1}

"Monitoring Naw Sites, Procesees, and Fucilities. An environmental survey shall be conducted prior to actuil btort up of a new siten, facility, or process which has the potential for adverse environmental impact, or which will process, release, or dispose of pollutants. The preoperational survey should begin about 2 years, but not less than 1 year before stant up to cover sessonal chinges dequatefy. The survey shall establish background levels of tadioactive and toxic pollutants; chinructerize pertinent environmental and ecological panameters; ind julentify potential pathways for human exposune or environmental impact as a basia for deternining the nature and axtent of the sabsequent routine operational effluent and environmental monitoring program."

\subsubsection{RCRA Facility Inspections}

This athelement specifies the requirements for an interbal inspection program to verify that provisions of the dengerous wasts permit ane being met

\section{FACILTTY REOUIREMENT SOURCE: WAC-173-303(931208) Section 320(1)}

(1) The owner or operalor shall inspect his facility to prevent malfumetions and deterioration, operator erross, and discharges which may cause or leat to the release of dergerous waste constituents to the environment, of a threat to human health. The owner or operatior must conduct these inspections often enough to identify problems in time to correct tiem before they herm human beslth or the enviropument" 


\section{STANDARDS REQUIREMENTS IDENTIFICATION DOCUMENT FIGH IEVEL WASTE STORAGE TANK FARMS \\ Environmental Protection \\ WHC-EP-0750}

FACIIITY REQUIREMINT SOURCE; WAC-173-303(931208) Section 320(2)

"(2) The ownet or operabor shall develop fnd follow a written schedule for inspecting alt monitoring equipment, sefety and emerpency equjpment, eecurity devices, and operating and structuril equipment that help provent, detect, or respond to haxirds to the public heatth or the environmeat. In dedition: (a) He wrist keep the schedule at the facility;

(b) Tho schedule must idsoutify the types of problems which are to be locked for during inspections;

(c) The schedule whall indicats tbo frequency of inspection for specific items. The frequency should bo besed on the rate of possible deterioration of equipment, and the probotionity of an exvironmental of humen health incident. Areas aubject to spilla unst bo inspected datily when in use. At a minimum the inspection schedule shell also inchude the applicalile iterns and fequencies required for the specific waste management methods described in 40 CFR Part 265 Sulbparts F through R for interito status facilities and in WAC 173-303-630 through 173-303-680 for final stems fxcilities; and

(d) The owner or operator thall keep an inspection log or aummary, including at least the date and time of the inspection, the pitinted name and the bandwritten signature of the inspector, a notation of the abservations made, an wecunt of spills or disebarges in sccordance with WAC 173-303-145, and the date and netures of any reppirs or remedial actions taken. The log or sommery must be kept at the fuility for at lest five years from the date of inspection."

FACIITY REQUHREMENT SOURCE: WAC-173-303(931208) Section 320(3)

"(3) The owner or operator shall remedy any problems reveeled by the tuspection, on a schedolo which proverts berards to the public health and environment. Where a hazard is imminent or has alresty occurrod, remedial action must bo taken inmediately."

18.2.7 Danqerous Waste Tanks

This subelement specifies the inspection requirements of WAC-173-303-640 for dagorons waste storage tanke.

\section{FACILTY REQUIREMENT SOURCE: 40CHR264 Part 15(a)}

The owner or operntor must inspect his facility for malfunctions and deteriomation, operator enors, and disuharges which miy be cansing - or may lead to - (1) release of herrotouss waste constituente to the eavironmeat or (2) 1 threat to human bealth. The owper or operstor must condunt these inspections often enough to identify problems in time to correct them before they harm humas hesfith or the enviroument."

\section{FACILITY REQUIREMENT SOURCE: WA7890008967-DW Part I.U.1.}

Within 12 months of the effective date of the Permit, the Permittes shall submit 1 report to the Department which describes the procedures to be used to compile the information rexuired by Conditions II.U. 2, II.U.3., and II.U.4. The report shall deseribe the modhods which will be used to retritve the piping information, the extimated eccuricy of the date to bo provided, quality assurance/quality control technique to be employed incluting field verification ectivities (i.e., surveying, ground penetrating narlar, etc.) to support information gathered from 


\section{STANDARDS REQUIREMENTS DENTIFICATION DOCUMENT HIGA LEVEL WASTE STORAGE TANK FARMS \\ Environmental Protection \\ Whe-Bp-onso}

existing dnawingo, mond conceptaal examples of the produst which will be submitted."

FACHITT REOUREMENT SOURCE; WA7890008967-DW Part H.U.2.

Within 24 months of the effective date of this Permit, the Parmittes shenl make an initisd ontumittal to the Department of mept showing the Iocation of dangercos waste underground pipelines (including active, tractive, and abandoned pipelines which contain or contrined dengerous waste subject to ths movisions of Chapter 173-303 WAC) on the Facility which are locested outbide of the fapces eaclosing the 200 East, 200 West, $300,400,100 \mathrm{~N}$, snd 100X Areas. These mopa shall identify the origin, destination, size, depth and type (i.t., reinforced concrete, stainless steel, cast itm, etc.) of ench pipes and the location of their diverstion boxes, valvo pits, seal pota, catch tanks, receiver tanks, and pumps, uiliziog Washington 3tate Plans Coodifinetes, NAD 83(91), meteri. If the type of pipe material is not docmentented on existing drowinge, the most probable material type shall be provided. These mapa shall be ccompanied by a description of the quality assunence and quality control measures used to compile the mapa.

The age of all pipea required to be identified pursuant to this Condition stall be docuuneated in in enturfiment to the submittal. If the age connot be documented, an estimats of the age of the pipe sinall be provided besed upon best engineering judgoment.

These mepe, and any altechments, ahall be matumined in the Facility Operating Record end updated anmually efter the initial submittal with new or revised information."

\section{FACILITY REQURREMENT SOURCE: WA7890008967-DW Part ILU.3.}

"Withts 36 months of the effective date of this Perratit, the Pertrittees shall moke mn initial submittal to the Department of piping schematies for dangerous waste underground pipeltwee (including active, inective, and tbandoned pipelines which contain or contained dangerous waste subjext to the provisions of Chapter 173-303 WAC) within the 200 East, 200 West, 300 , $400,100 \mathrm{~N}$, ind $100 \mathrm{~K}$ Aress. The pipting schematics shall identify the origin, destination, and dtrection of flow for each pipe, as well as whether the pipe is active, intective, or abandoned. These diagrams need not inclute the pipes within a fepeed unk farm or within a

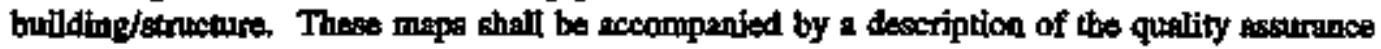
and qualtity contunl mesasurea used to compila the maps.

These dlagrams, and any attachments, skall be maintoined in the Facility Operating Record and updated annusily after the initial submittal wilh new or revised information."

\section{FACIITY REQURREMUNT SOURCE: WA7890008967-DW Part II.U.4.}

Within 36 months of the effective date of this Permit, the Parmittees shall make an iutitial submittel to the Department of mixps showing the location of dangerour waste undergromid pipelines (including active, inactiva, and abandoned pipelines which contain or contrined dengenoun waste subject to the provisions of Chxpter 173-303 WAC) within the 200 Eest, 200 West, $300,400,100 \mathrm{~N}$, md $100 \mathrm{~K}$ Areas. These maps will incorporate informetion available six months prior to the scheduled subarittal date. Thereafter, the maps will be updated on an amual beais to incorporate additional information, es such information becomes availatis in sccordence with the FFACO milestone schedule. A schedule for the provision of mep input shall be included in the report specified in Condition II.U.1.

The mapa shall identify the origin, destination, sizs, depth and type (i.e., reinforced concrete, stainlest ateel, cest iron, etc.) of each pipe and the locetion of their diversion boxes, valve pits, saal pots, catch taniss, receiver tanks, and pumps, and utilize Washington State Plad Coordinates, NAD 83(91), meters. If the type of pipe material is not documeoted on existing 


\section{STANDARDS REQUIREMENTS IDENTIFICATION DOCUMENT HIGH LEVEL WASTE STORAGE TANK FARMS \\ Environmental Protection \\ WHCEROTSO}

deawinga, the mot probable material type shall be provided These mapg need mot inctuds the pipes willin a fenced tank farm or within a buikting/strueture. These maps sholl be acconqumied by a description of the quality assurnase/quality control used to compila the maps.

The age of all pipes required to he identified pursuant to this Condition sholl be documented in an attrochment to the sobmittal. If the age canot be documented, an extimste of the age of the pipe ehall be provided besed upon best engineering judgement.

These diagrams, and any altanhments, shall be mointained in the Facillity Wide Operating Record and updated anpurilly after the intitil submiltal with new of revised toformation."

\section{FACIITY REQUIREMENT SOURCB: WA7890008967-DW Part II.V.}

Within 24 months of the effective date of this Permit, the Perurittees thall mark the underground pipelines identitied in Contition II.U.2. These pipelinss atsall be matked at the point they pass bereath a fence enclosing the 200 Esst, 200 West, 300, 400, $100 \mathrm{~N}$ or $100 \mathrm{~K}$ Arens, at their origin and destination, at my point they cross an inproved road and evory 100

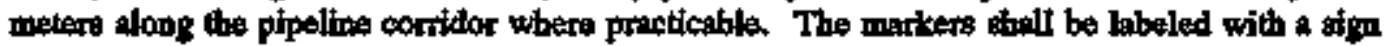
that reate "Buried Derogerours Waste Pipe" and thith be visible from a distonce of 15 meters."

\section{FACILIIY REQUTREMAENT SOURCE: WAC-173-363(931308) Section 640( 6)}

"640 (6) Inspections.

640 (6) (n) The owner or cperator must develop and follow a schedule and procecture for inspecting overfill controls.

640 (0) (b) The owner or operator must inspect at least once each operating day:

640 (6) (i) Aboveground portions of the tank system, if any, to detoct comosion of roleased of wiste;

640 (6) (it) Data puthered from monitoring eny leak detection equjpment (e.g., pressure or temperature ganges, monitoring wells) to ensure that the tank system is being operated according to its desifer; and

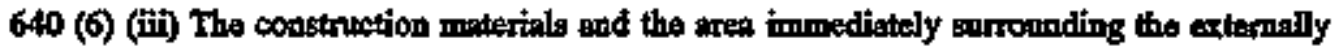
woevibis portion of the tank system, inoluding the becondary contrinment system (0.g., dikes) to detect erotion of aigns of velenses of dengerous waste (e.g., wet epots, dead vegetation). Notes WAC 173-303-320 requives the ouner or operator to remedy and deterioration or melfunction he firds. Subeection ( 7 ) of this section requires the owner or opentor to notify the depertment within tweaty-four hours of confirming a leak. Also, 40 CFR Part 302 moy require the owner or operator to notify the National Response Center of a celease.

640 (6) (c) Tho owner or opefotor mest inspect cathodio protection syetems, if present, acconding to, it a minimum, the following schedule to engure that they ane functioning properly:

640 (6) (1) The proper operation of the calhodic protection aystem most be confirmed within air months after initial installation and anmsally thereafter, rod

640 (G) (ii) All sources of impressed current must be inspected and/or tested, as approprater, at least himonthity (i.t., overy other wonth). 


\section{STANDARDS REQUIREMENTS IDENTEICATION DOCUMENT HIGH LEVEL WASTE STORAGE TANK FARMS \\ Environmental Protection \\ WHC-EP-0750}

Note: The prectices described in the National Association of Corrosion Engineero (NACE) stardard, Recommouded Pratice (RP-02-85)-Control of External Corrosion on Metallic Buried, Purtially Buried, or Submerged Liquid Stonge Systems," amd the American Petroleum Institute (API) Publication 1632,

"Cathodic Protection of Underground Petroleum Storage Tanks and Piping \$ytems," may be used, whero appliceble, a guidelines in maintaining and inspecting cathodic procection systems.

640 (6) (d) The ownet of operator mast document in the operatitis record of the facility an inspetion of those itewn in (a) throuth (c) of this subsection. The owner or operator ahall keep an inspection log ficluiling at least the dito and timb of the inspection, the printed name ard the handwritten afgenature of the inspector, a notation of the observations msde and the date nend nature of any repairs or remedial actions taken. The log must be kept at the facility for at least five years from the date of inspection. -

18.2.8 Surface Impoundimentis

This gubelement epecifies the requirements of WAC 173-303-650(4) for monitoring and inspection of surface impoumdments.

FACILITY REQUIREMENT SOURCE: WAC-173-303(931208) Section 650(4)

Monitoring and insection.

(a) Duting construction and tistallation, liners (except in the cese of exishing portions of sorface imponpdivents exempt from subsection (Z)(a)(i) of this section) and cover systems (e.8., memtranes, sheets, or costings) must be inspected for uniformity, damage, and imperfections (e.g, holes, craxks, thin spots, or foreign materials). Immediately after construction or installation:

(i) Synthetio liners and covers must be inspeded to ensure tinfte searns and joints and the Albences of teirs, punctures, of btistror; and (ii) Soil-based and admixked liners and covera must be inspected for imperfections inclusting lenses, eracks, chinnels, root holes, or other

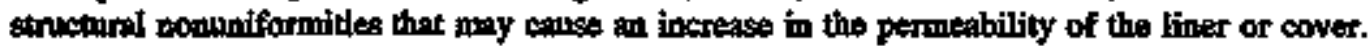
(b) While a surface impoutudment is it operstion, it minst be inspected weekly and after stotins to detert tidence of any of the following: (i) Deterioration, malfumctions, or improper opention of overtopping control systems;

(ii) Sudden dropa im the level of the impoundment's contents; (iii) The presence af liquids in leak datection systems, whers installed to comply with subsection (3) of this section; and

(iv) Severe erosion or other signs of deterioration in dikes or other containment devices.

(c) Prior to the issuance of a prermit, and after any extended period of time (at lesst six months) during which the infoundment was not in service, the owper or operator must obsiti a certification from a qualified engtineer that tho impoundment's dike, inchuding that portion of any dike which provides freeboard, has structural integrity. The certifichtion mist establish, in particular, thet the dike:

(i) Will withstand the stress of the pressure exerted by the types and amounts of wastes to be placed in the impoundment; and

(ii) Will not fail due to scouring or piping, without dependence on any liner syatem included in the surfece impoumdment construction."

18.2 .9 Ourality Assurance 


\section{STANDARDS REQUIREMENTS IDENTIFICATION DOCUMENT FIGH LEVEL WASTE STORAGE TANK FARMS \\ Environmental Protection \\ WHC.Ep-0750}

This subelement defines the quality asentruce requirements wssociated with environmentel

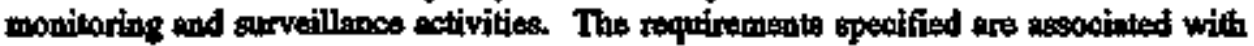
andingling, andyticel quality control, instrumentation, quality of records, ets. The requiremsent for resordkeping is epecified by NRC Regulatory Guids 4.15 and is considered a beat monagement panctice. DOE/E0135 wod DOE/E0173T are guidance documents and are not tho counces of enforcelhle tequiremonto.

\section{FACLITY REQUIREMENT SOURCE: DOE/EH135 TS.5.2}

-All pointe of potential release of radioactive and havarious meterial to the envirommeat from each feility are monibred enficiently to provide assurance that the quantities and quelities of the releses are known."

\section{FACILTY REQUIREMENT SOURCE: DOE/EHOI35 TS.5.7}

"Instrumedation is periodically cellibrated and hos proper aceuracy mod range."

\section{FACILITY REQUIREMENT SOURCE; DORAHOI73T Section 10.32}

"Each aite is required to maintein an analytical QC program adequate to document and control the securacy end presision of the analytical results. If analytical work is performed by a

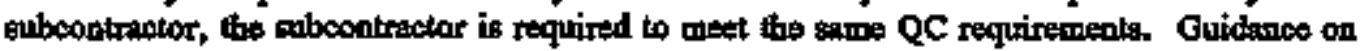
conteat of apelytical QC programs is provided by Belenger (1984), Golbin (1970), Rosenstein and Goldin (1964), EPA-600/9-76-005, EPA-600/7-77-088, EPA-600/8-78-008, ind EPA-600/4- 79-019.

DOE 5400.5 requires that all organizations performing efflueat of envimmentio monitoring participate in the DOE quality assessment program for those nuclides and media thet they regularly measurb. Sumples are distributed by tha Envircnmental Measurements Laboratory (EMI) twice y year, and participents analyze both sets of samples. DOE monitoring orpenizations shotild participate in other inter|alongtory QC proprams such as the EPA Environmental Radioactivity Laboratory Intercomparison Studies Program (EPA600/4-78-032).

Radiation messuring equipment, iraludiog portabla instruments, exvironmental dosinemes, in situ monitoring equipment, end laboratory instruments, should* be calibrated with standarids troceable to NIST calibrotion standerds (NCRP 1978; National Burent of Standands Special Publicotion 609)"

\section{FACMTIY REQUIREMIENT SOURCE: DOE5400.1 Chapter IV, Section 5.a(2)(d)}

"Monitoring Date Recordkecping. Auditatle rocords shall be estoblished in eccordenco with tho requirements of DOE 5700.6C QUALITY ASSURANCE."

\section{FACILITY REQUIRFMENT SOURCE: DOE340D.1 Chapter IV, Section 10.8}

"Quality Assurence aud Data Verification - Quality Assurnoce. A quality assurance program combistent with DOE 5700.6B shall be establisted covering each element of environmental monitoring and arveillance programs commeusarate with its nature and complexity. The quelity usgurance program ahall include, but not be limited to, the following: 


\section{STANDARDS REQUIREMENTS IDENTIFICATION DOCUMENT HIGH LEVEL WASTE STORAGE TANK FARMS \\ Environmental Protection \\ WiC-EP-A7so}

(1) Organizationel responsibility;

(2) Program design;

(3) Procedurea;

(4) Field quality control;

(5) Leboratory quality control;

(6) Humen factoms

(7) Recortkeeping;

(8) Chatin-of-custody procedures;

(9) Antiti;

(10) Performance reporting; snd

(11) Independent data verification."

\section{FACILITY REQUREMENT SOURCE: TPA Part Five, Article XXXI, Section 105}

-Throughout all aample collection, preservation, transportation, and andlysea setivities required w implement this Agreement, DOE shall use procedures for quality assurmce, and for quality control, in accordance with approved EPA methods, including subsequent amendments to such procedures. The DOE shall comply with the "Data Quality Strategy for Hanford Site Charseterization" (Bs listed in Appendix F of the Action Plan) and Sections 6.5 and 7.8 of the Action Plen. For speciat circumstantes, other procedures tuproved by the ked negulatory agency may be used. The DOE shall use methods and analytical protocols for the parameters of concern in the medin of imterest within detection and quantification limils in excondance with both QAVQC procedures and date quality objectives approved in the work plan, RCRA closurs plan or RCRA perrit. The EPA or Ecology may require that DOE sutimit detriled information to denonstrate that any of its laboratorits are qualified to canduct the work. The DOE shall nssure that EPA and Ecology (inciuding contractor personnel) bave access to laboratory persomnel, equipment and records related to sample collection, transportation, and analysis."

\section{FACILITY REQUIREMENT SOURCE: USAEC-RG1.86 Section C.5}

"Quality Coatrol in Sampling (Including Packaging, Shipping, and Strrage of Somples)

Continuous sampling of liquids and gases involves the measurement of sample flow rates and/or samples vohumes. The eccuracy of the devices used for this pupose should bo determined on a rigularty setheduled basis, and ajustments should be made as needed to bring the performance of the devices within specified limits, The results of these calibrations should be recorded. The fitsquency of these calibrations should be specified and shmuld be based on the required seculney, purpose, degree of usenge, stahility characteristice, and ather conditions affecting the meesursement. Procedures for continuous sampling should use methods that are

designed to ensure that the sample is representative of the material volumes sampled. The collection efficiencies of the samplars used should be documented; ussally such documentation is avaitable from manufacturers of the sampling equipment.

Procedures for grab samples should include stejes designed to ensure that the sample is nepresentative of the material sampled. Representativs grab samples should be taken periodically to determine the reproducibility of sampling.

Procedura for sampling, packaging, shipping, and storige of samples sbould be designed to maintain the integrity of the sample from tims of collection to time of anslysis." 


\section{STANDARDS REQUIREMENTS IDENTIFICATION DOCUMENT HIGH LEVEL WASTE STORAGE TANK FARMS \\ Environmental Protection \\ พTC-9P-0T50}

\section{Undercround Storage Tanks}

This subelement specifies the requitements for telease detection of undereround tanks and piping conveying regulated aubstances.

\section{FACIINTY REQUIREMIFNT SOURCE: WAC-173-360 Section 335}

"Relesse Detection For Petroleam UST Systemg

(1) Owners and operitory of new and existing petroleum UST systems shall provide a method, conbination of methods, of release detection that:

(a) Can detect a releese from any portion of the tank and the conoected underground piping that routinely containu a regulated aubstances

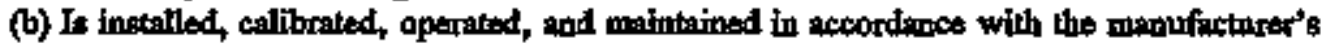
instruction, including routine maintenanes and service checks for operability or ruming condition; and

(c) Mests the performance requirements in WAC 173-360-345 or 173-360-350.

(2) Owners and operators of petroleum UST systems shall monitor tanks and piping for released as follows:

(a) Tanks. Tanks shall bo monitored at least overy thirty days for releses using ons of the mothods listed in WAC 173-360-345(6)(0) throngh (O) except as provided in' WAC 173-360-345(2) through (5).

(b) Ptping. Underground piping that routinely contuins ragulated substances shall bo monitored for relesses as required under WAC 173-360-350.

(3) Owners and operatara of ayy existing UST systim that cennot apply a method of releose detection that complies with the applicente requirements of WAC 173-360-330 tirouth 179-360-355 ahall complete the closure procedures in WAC 173-360-380 through 173-360-398 by the dete on which release detection is required for that UST system moder WAC $179-360-330$.

\section{FACILITY REQUREMENT SOURCE: WAC-173-360 Section 350(1)}

"Any method of release detection for piping shall met the performance requiriomedty of this section, with any performance elaims and their manner of deternination described in witing by the equipment manufecturer or installer. In addition, methods nsed after Dectritber 22, 1990, exeept for methods permanentiy installed prior to date, shall be capable of detecting the lesk mote or quantity epecififed for that method in subsection (3)(B) and (b) of thit section and with a probability of detection of 0.95 and a probability of false alarm of 0.05 . (That is, under test conditions, a method will contecty detect at least ninety-fivo of one hundred ictanl releases, apd will falsely indicate a release no more than five times in wo biodred teste of nonlealing systems.)"

\subsubsection{Waste Piles}

This subelement apecifies the requirements of WAC 173-303-660(S) for monitoring foud inspection of waste piles. 


\section{STANDARDS REQUIREMENTS IDENTIFICATION DOCUMENT HIGH LEVEL WASTE STORAGE TANK FARMS \\ Environmental Protection \\ WHC-EP-OASA}

FACIITY REQUIREMENT SOURCE: WAC-173-303(931208) Section 660( S)

"Monitoring and inspection.

(a) During construction or installation, liners (except in the case of existing portions of piles exempt from subsection (2)(a) of this section), and cover systems (e.g., membranes, sheets, costings) must be inspected for uniformity, damagen and imperfections (o.g, holes, cracks, thin apots, foneign materials). Immediately after construction or installation: (i) Synthetis liners and covers must be inspected to ensure tight seams and joints and the absence of tears, punctures, or blisters; and (ii) Soitbased and admixed liners and covers muss be inspected for imperfections inchuding lenses, errecks, chamels, root holes, or other structural noumbiformities thet may conse en bereese in the permeability of the liner or cover.

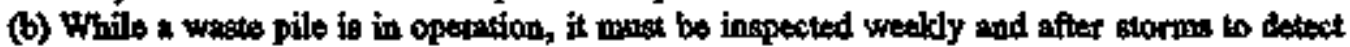
ovidence of pary of the following:

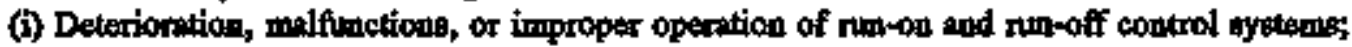

(ii) The preseace of liquida in leak detection systems, where installed to comply with gubsection (3) of this section:

(iii) Proper functioning of wint dispersal control systems; and (iv) The presterce of leachate in and proper functioning of leachato collection and removal systems."

\section{PERMTTS}

This element specifies the requirements for identification of necessary permits, permit application processes, and permit contents. Permitting requirements for water, air, and RCRA TSD facilities are specified, in eddition, program rexuirements for the NEPA program are tocluded.

\section{Clean Water Permits}

Liquid effluent discharges to waters of the US require \& permit under the National Pollution Discharge Elimination System (NPDES). While the TWRS does not have a procesa discharge to aurface water, stormitater poteatially ein contact contaminated equipment, which would resalt in the requirement for in NPDES Stormwater permit.

\section{FACHITY REQUTRGMENT SOURCE: WAC-246-272 Section 090(1)}

"No pereon shall install or causo to bo installed a new on site sewage system, nor perform any alteretions, extensions, of relocations of comnections to an existing cyatem without a velid permit inued by the heelth offices. Larger on-site sewage systems epproved by the depertment are exempt from permit requiremente. Permits for alterations of repoirs shail be so identified. Appliestion for euch permit shall be unde in waiting in a manner prescribed by the he:lth officer. Eech permit application shall inchude a reminder of the applicant'a right of appeal. The anthority to issue permite shall not be delegated by the health officer."

\subsubsection{Clean Air Permils}

This subelement spexifies requirements for sources end emission units to meet Federal and State emission standards, and to obtain and comply with gir quality permits.

FACILTY REQUIREMENT SOURCE: 40CFRG1 Part 96(b)

-Application to Construct or Modify 


\section{STANDARDS REQUIREMENTS IDENTIFICATION DOCUMENT HIGH LEVEL WASTE STORAGE TANK FARMS \\ Environmental Protection \\ WHC-BPA750}

(b) An application for approval under 61.07 of notification of starthe under 61.09 does not need to be filed for any new conetnuction of or modification within an oxisting facility if the offective dose equivalent coused by all emissioms from the new canstrultion or modification, is lese than 1\% of the standard preseribed in 61.92. For purposes of this paragraph the effective dase equivalent shall be calkulated using the source term derived using Appendix D a input to tho disparsion and other computer models deseribed in 61.93. DOE may, with prior approval from EPA, use another prosedure for estimating the source term for uso in this parragraph. A facility is eligible for this exemption only if, based on its last annual report, the factitity is in compliance with this subpart."

\section{FACILITY REQUIREMFNT SOURCE; WAC-173-490 Section 110}

-Constrution shall not commence, on any new source that is requited to register per WAC 173-400-100, rutil in notice of coustrution bes been approved per WAC 173-403-050. The owper or operitor of way source that is required to register per WAC 173-400-100 shall notify the departuneat of copnizant locel althority priox to replacement of air pollution control equipment or process equipment ather than neplacement for routine maintengnce mol repair. The department or authority may determins that a notics of construction is requirect."

\section{FACIHITY REQUIRTMIENT SOURCE; WAC-173-480 Section 60}

"Exisaion Strondards New and Modified Emission Unibs

(1) Whenever the construction, installation or esteblishment of a new einission unit subject to this chapter is contemplated, the project chall utilize best available radionuclide control technology (BARCT).

(2) Addition to, enlargement, modificetion, replacement, alteration of any process or emission unit or replecemeat of air pollution control equipment which will sigmificently change potential

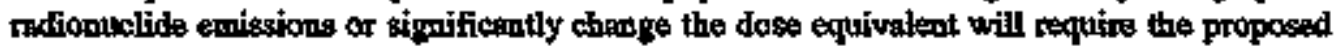
project to utilize best available radionthelide control tectuology (BARCT) for amission control."

\section{BACILITY REQUEREMENT SOURCE: WAC-246-247(940131) Section 060 Introduction}

"This section describes the information requirements for approval to construct, modity, and operats an emisuion unit. Any notice of constraction (NOC) requires the submittol of the information listed in Appendix A. Complex projects may require wdditional informotion. The

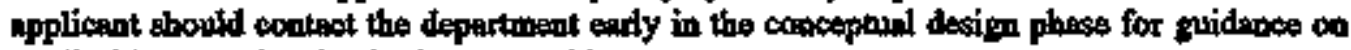

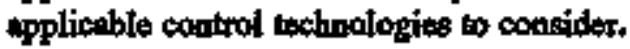

Appenidices B and C outline the procechures to demonstrato compliance with the BARCT and ALARACT etandards Besed on tho Appendix A information provided, the department may stuise the sppticant which subset of technologies to consider as cendidetes for meeting BARCT or ALARACT requirements. For those facilities subject to the opsrating parmit regulations in chepter 173-40I WAC, the radipactivo air emissions license will be incorporated as an epplicable portion of the air eperating peronit issued by the department of ecology or a local air pollution control authority. The deprartmeat will be responsitile for determining the facility's complianes with and enforeing the requirements of the partionetivo air entisstons liceuse."

FACIITYY REQUTREMEAN SOURCE: WAC-246-247(940131) Section 060( 1) 


\section{STANDARDS REQUIREMENTS IENTUICATION DOCUMENT HIGH LEVEL WASTE STORAGE TANK FARMS \\ Environmental Protection \\ WHC-Er-0750}

"Requirencents for new coustruction or modtfication or emisosion units.

(a) Exrly in the design pbose, the applicant shall submit a NOC containing the ioformation required in Appendix A.

(b) Within thirty doys of necipt of the NOC, the deparment shall inform the applicant if edditional information is required. The department mny determine, on the basio of the informotion subinitted, thet the requirements of BARCT or ALARACT have been met, of why require the appliseant to suburit a BARCT or ALARACT demonstration coripatible with Appendix B or C, respectively. (c) Within sixty days of receipt of all required information, the departrent shall isswe an approvil or dexial to econstruct. The tepartment may requirs changes to the final proposed control technology.

(d) The applicant may request a phased appovval process by so stating and submitting a limited application. The departuent may grant a conditional approval to constrict for sach activities 18 would not prectude the construction of installetion of any control or monitoring equipunent required after review of the completed appliction.

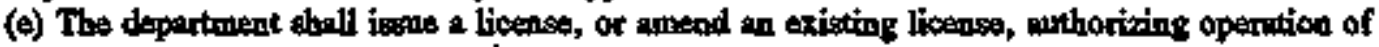
the emission unit(s) when the proposed nsw construction or modification is complete. For facilition sabject to the air operatiog permit requirements of chapter 173-401 WAC, the license shall becoms part of the yir operating permit issued by the depertmeat of ecolocy or a locel sir pollution control authority. For new constraction, this action shall constitute registration of the emission unit(s)."

\section{FACILIY RDQUIREMENT SOURCE: WAC-246-247(940131) Section 060( 2)}

"Requirements for modification of unregistered emission units that are not exempt from these regulations.

(a) The applicent ghall submit an application containing the information required in Appendix A.

(b) Within thirty days of receipt of the epplication, the departoment sball inform the applicant if additional inforuation is required. The department may detsromins, on the basio of tho baformation submitted, that the requirements of BARCT or ALARACT demonstration compatible with Appendix B or C, respectively.

(c) Withis sixty days of receipt of all required information, the departoment shall isese of armend the license. For facilties subject to the eir operating permit requirements of chapter 173-401 WAC, the license sholl become part of the air operating perint isound by the depertment of ecology of a local ait pollutiou control nuthority. This action shall constitute vegistration of the mission unit(s). A determination of nomcompliance may restlt in the issunce of a notice of violation.

(d) The department reserves the right to requirs the ownor of an existing, undegistered emianion unit to make modifications necessery to comply with the spplicesble stondarits of WAC 246-247-040."

\section{FACIITY REQUIREMENT SOURCE: WAC-246-247(940131) Section 060( 3)}

"If wh emiesion unit is in violation of any standinds contsined in WAC 246-247-040, the facility stall either submit a compliance plan which describes bow it intonds to thieve compliance with the standards, and/ar cease operation of the enission unit(s). The facility stall autmit the compliance plan within forty-five days of the notice of viotation. The cesention of operation of the emisation unit(s) shall not necescorily exeunt the facility from the jequirementi of this chapter if active or passive vertilation and radipoctive afr emistion 


\section{STANDARDS REQUIREMENTS IDENTIFICATION DOCUMENT EIGH LEVEL WASTE STORAGE TANK FARMS \\ Environmental Protection \\ WHC-ER-0750}

controls will still be requined. The department reserves the right to take further enforcement ection, if necessury, in eccordance with WAC 246-247-100."

\section{FACILITY REQUIREMENT SOURCE: WAC-246-247(940131) Section 060( 4)}

Tho freility sholl notify the department t least seven colendar days prior to any plannod preoperational teste of new or modified emission tmits that involve emissiong control, monitoring, or containment systems of the emission trit(s). The department recerve the right to witness or requine preoperational teste involving the emissions control, momitoring, or conterinment aystems of the emission unit(8)." .

\section{FACIITTY REQUIREMIENT SOURCE: WAC-246-247(940131) Section 060( 5)}

The license shitl specify the requirements and linitations of operation to sssors complinace

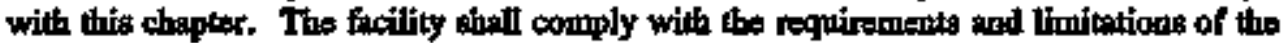
license."

\section{FACIITTY REQUIREMATNT SOURCE: WAC-246-247(940131) Section 060( 6)}

"All radinertive gir tmissiong licenses issued by the department, except those issued in rediosetive materisls licenses, shall have su exptration date of five years from date of issuano or as specified in the air operating permit. For maflooctive meterial ticenses, tho requirements and timitations for the operation of emission units shall be incorporated into their raditoactive matrerials Hcense, and shall expire when the radioactive materials license expires."

\section{FACILITY REQUIREMENT SOURCE: WAC-246-247(94013t) Section 060( 7$)$}

"Esch federel facility that comes under the suthority of this chapter shall hoid one license for exch site, base, of instellation. When applisable, the license shall be part of the ficility's pir operating perritit."

\section{FACILTY REQUIREMANT SOURCE; WAC-246-247(940131) Section 060( 8)}

"Facilitisa may request a singlo categorieal license which identifies limits and conditions of operation for similar multipupose temporary and/or portable emission naits. When applicable, the licenes athall be part of the focility's nir openting permit."

\section{FACIITY REQUIREMENT SOURCE: WAC-246-247(940131) Section 060( 9)}

"All faciltities with ticensed enisstion units, except for radioactive materials licensess, hall

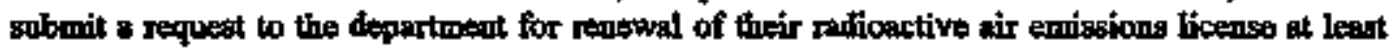
sixty daye prior to expiration of the licese of as required by the air operating pornit. All

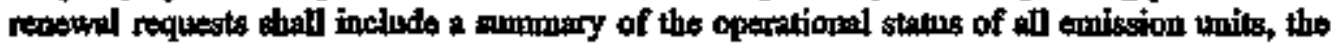
stimg of facillty compliance with the standartis of WAC 246-247-040, and the stontro of any corrective actions necessery to schieve compliance with the requinementa of itis chapter. Facilitiea with licensed emission units that also bold a radicactive materials licenso sond by the department shall submit this information along with their radiosetive meterial license renewal submittsl. If the department is unsble to renew a radiosetive air emissions licenso before its expiration date, the oxisting license, with all of its requinements and limitations, remains if force until the department either renews or revoles the license." 


\section{STANDARDS REQUIREMENTS IDENTLFICATION DOCUMENT HIGH LEVEL WASTE STORAGE TANK FARMS \\ Environmental Protection \\ WHC-ER-0750}

\section{FACILITY REQUIREMENT SOURCE; WAC-246-247940131) Section G60(10)}

"For commarciel meleor power plants or any other thermal energy facility subject to chapter $80.50 \mathrm{RCW}$ and to the requirements of this chapter, the radiosctive atir emissions license and

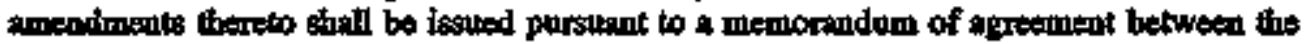

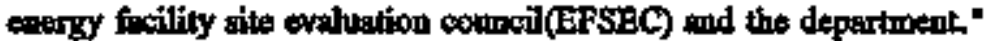

RCRA TSD Facility Permilts

Thio subelement epecifies progmannatio requirements for dangerous waste facilities that must obtain acd mointrin a RCRA Part B permit

\section{FACILITY REQUIREMINT SOURCE: TPA Attachment 2, Section 3,4.2}

"Prioritizition of Trement, Stronge, and Disposal Units

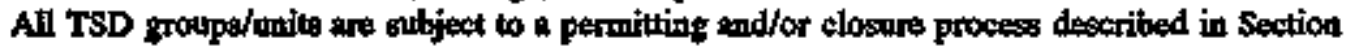

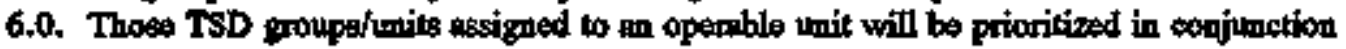
With pest-proctice priorities for purposes of investigation. The order in which permit applications or closers plens will be developed for the rempining TSD groups/units is based on consideretion of the following criterio.

- Eovircomentil Risk. The risk to pubitic belth and environment is the most important consideration. Ady action that will significently reduco the risk to public heodth and/or the envirantent will be coasidered the highest priosity.

- Waste Minimization. Waste minimization is centrel to the goel of reducing environmental risks and bringing about environmental compliance for continuing operations and for new verits at the Heaford Site. Therefore, the parties agree that Ecology's "Prionity Wagle Management Poticy" (Eeology 86-07), established pursusint to CH. 70.105.150 RCW, shall be arthered to as guidence for purposes of estsblishing permitting priorities, in addition to evaluating proposed ctionges in operationsl procedares, end for the development ind implementetion of now waste mangement strategtes. This policy defines the following prioritized actions: (1) waste reduction, (2) recycling, (3) treatment, (4) stabilization, and (5) jand dispoesl.

- Permit Application Dates Required by Law. The Hazardons end Solid Wasto Amendements of 1984 (HSWA) mandated dates for submittal of Part B permit applicetions. The datee for submitting dangerous waste (excloding mixed wasta units) Part B permit applications were is follows:

- Laud dispoesl troits: November 8, 1985

(all requived Part B applicotions were aubmitted pritor to this date)

- Iocinerntion unitos: Novaruber 8, 1986

(not applicahis for the Henford Stte)

- Trestment end storage unitse November 8, 1988.

Part A permit applications for all mixed waste units that will be operating under interim stotus were dub by May 23, 1988 (this date was met for all such known units). Patt B permit applications for the disposed of mixed waste to land disposel noits were due by November 23, 1988 (this dete was met for all such trown units), fincluting the certificariod statement requitred by Section 300S(o)(2) of RCRA, that the unit is in compliance with the intrime stons groundusater monitoring requirements. Thers ate no stantory Part $B$ permit application dates for mixed wstb treatment end atorage units.

- Operational Requirements. Some operational considerations art importont for Insintaining or echieving environmental compliance, continustion of Hanford Sits operations, or whieving cleanup in a cost-efective manner. Examples of such operational considentions includs permitting i treatment unit for operation or accelerating closure actions to complement 


\title{
STANDARDS REQUIREMENTS IDENTIFICATION DOCUMENT HGA LEVEL WASTE STORAGE TANK FARMS \\ Environmental Protection \\ whe-BP-0750
}

decontemination and decomminssioniog of telated structures.

\author{
FACILTX REQUIREMIENT SOURCE: TPA Attachment 2, Section $\mathbf{5 . 3}$
}

\begin{abstract}
"MANAGEMENT OF TREATMENT, STORAGE, AND DISPOSAL UNITS
As previousily stored, TSD units are ldentified in Appendix B. Any additional TSD unito thet are suberquenty ideatified stall be added to Appendtx $B$ in accordance with tho process described in Section 12.2 .

Unless clased in mecortance wilh Sections 6.3.1 or 6.3.3, TSD units statl be porrititted for sither operation of postelosure care pursuant to the authorized State Dangerous Waste Progrim (173-303 WAC) and HSWA. Prior to permitting or closure of TSD tnits, DOE shall actheve

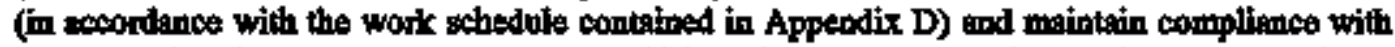
applicable interim status requirements. AII TSD units that undergo clasure, imespective of permit stans, shall be closed pursibant to the anthorized State Dangteroul Waste Program in accordince with 173-303-610 WAC."
\end{abstract}

\section{FACILIIY REQUIREMENT SOURCE: TPA Attaciment 2, Section 5.5}

\section{-TREATMENT, STORAGE, AND DISPOSAL UNITS AND PAST-PRACTICE UNITS INTERFACE}

In soms ceses, TSD units are closely assoctated with past-practice units at the Houford Site, ther geographically or through sinilar processes and waste streams. Although disposition of auch units must be managed in accordance with Section 6.0, a procedure to soordinate this TSD unit clngure of permitting activity with the past-practice investipation and remediatsinn activity is necessary to prevent overlap and duplication of work, thereby economically and efficiently addressing the contamination. In Appendix B, selected TSD groups/units have been initially assignet to opersble units based on the criterie defined in Section 3.3. If at a later date TSD groupsinnits need to be deleted from or added to an operable unit, the procedurea defined in Section 12.2 will be used.

Ecolocy, the EPA, and DOE agre that pest-practice authority may provide the most efficient means for sddressing mixed-unasts groundwater contamination plumes oriyinating from a combination of TSD and past-practios units. However, in onder to ensure that TSD units within the operable units are brought finto compliance with RCRA and \$tats hazandons waste regulations, Ecolngy intends, sobject to part four of tho Agreemett, that all remedial or contrective artions, excluding sibuntions where thero is an imminent threat to the pallitie health or euvironment es described in Section 7.2.3, will be conducted in a manner which ensures complience with the technical requinements of the HWMA (Chapter 70.105 RCW and iks inmlementation regulations). In any case, the parties agree that CERCLA remedisel actions and, as appopriete, HSWA correctivs actions will comply with ARARs.

\section{FACIMTY REQUIRBMENT SOURCE: IPA Attachment 2, Section 6.3}

\section{"TREATMENT, STORAGE, AND DISPOSAL CLOSURE PROCESS}

The DOE will follow applicable Federal and State statutes, regulations and guidance documents, and written policy derminations that pertain to the closurs process for TSD groupssunita.

The TSD units containing mixed waste will nocmally be cilosed with consideration of alf harardous substanses, which includes radioactive constituents. Hazandous substances not addressed as part of the TSD closure may be addressed under CERCLA past-peractice (CPP) aulhority in accordance with the procese detined in Section 7.0.

The following ane exemples of when a unit may be closed without addressing all bazoridows aubstances (e.g., radiosctive waste). 


\section{STANDARDS REQUIREMENTS IDENTIFICATION DOCUMENT HIGH LEVEL WASTE STORAGE TANK FARMS

\author{
Environmental Protection
} \\ whc-tip-0750}

- For treatmeat of stornge units within a radioactive structure [0, $f$, the

Platonium/Orenium Extrution (PUREX) Plant] it may be possithle to remove all hazardous wabtes and "clem close" (see Section 6.3.1). The radionetive constituent would theo ramin for a fubiro decontamination and desommitssioning effort of the entire struthurs.

- For a land disposal unit being closed in canjunction with m operable unit, timitial investigation may show thet the unit no looger contains hazardous wasto or constituents. Therefore, the unit may be "clean closed" with no physical closure action. Any remaining CERCLA-only moterials would be addressed an part of the past-practica process as designated for that oparable unit.

Figure 6-2 depicts a flowchart of the closure process for TSD units. Two types of closures are shown."

\section{FACIIITY REQUIEEMENT SOURCE: WAC-173-303(931208) Section 141(1)}

"(1) A person shall onty offer a designated dangerous wasto to a TSD facility which is operoting either: Under a permit issted pursuant to the requirements of this chapter, or, if the TSD facility is loceted outsido of this stato, under interim status of a permit issued by United Stated EPA under 40 CFR Part 270, or under interim status or a permit issued by another state which has heed alltorized by United States EPA pursuant to 40 CFR Part 271.*

\section{FACIIIY REQUIREMAaNT SOURCE: WAC-173-303(931208) Section 141(2)}

"(2) A person meay offer a state only designated dangerous waste (not regulated aa a hazardous wasto by EPA) to a facility which is located outside of this state and which does not meet the requitements of subsection (1) of this section if:

(a) The facility rectiving the waste will legitimately treat or recycle the dangerous waste (dieposal is an unoceptable management practioc); (b) Tits generalor bas on fils a letter or copy of a letter signed by the regulatory authority in the receiving state that the receiving facility may accept the waste;

(c) The generator we tranfportar with a valid EPA/stete identification number;"

\section{FACILITY REQUIREMIENT SOURCE: WAC-173-303(93200) Section 800( 1)}

-The purpose of WAC 173-303-800 through 173-303-840 is to extablish the requirements for permits which will allow a dangerous waste facility to operate without endangering be public henlth and the environment."

\section{FACILTY REQUIREMENT SOURCE: WAC-173-303(931208) Section 800( 2)}

The ownerfoperator of a dangerous waste facility that transfers, treats, ctoces, or disposes (TSD) or recycleo dungerous wasto hall, when required by this chapter, obtain a permit in accordano with WAC 173-303-800 throuth 173-303-840 covering the active life closure

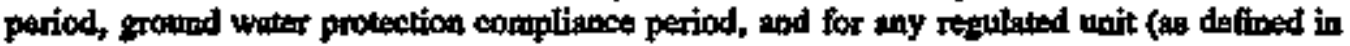
WAC 173-303-040) of for any facility which at closure does not meet the removil of decontamination limitg of WAC 173-303-610(2)(b), post-closure core period, unless they demonstrote closure by removal or deccotiomination as provided by WAC 173-303-800(9) and (10). The denial of a permit for the active lifs of * dengerons wasta mengemeat facility or tuit does not affect the requitemest to obtain is post-closure permit under this section."

FACILITY REQUIREMENT SOURCE: WAC-173-303(931208) Section 800( 3) 


\section{STANDARDS REQUIREMIENTS IDENTIFICATION DOCUMENT HIGH LEVEL WASTE STORAGE TANK FARMS \\ Environmental Protection \\ WAC-ER-0750}

TSD ficility permita will be grented only if the ohjectives of the siting and performance stanitords set forth in WAC 173-303-282 and 173-303-283 are met."

\section{FACILITY REQUPREMENT SOURCE: WAC-173-303(931208) Section 800( 4)}

Permits aball be issued woorting to the requirements of all appliceble TSD facility otandards.

\section{FACHTY REQUIREMENT SOURCE; WAC-173-303(931208) Section 800( 5)}

Tho owner/operator of a TSD fueility is responsible for obtuining all other applicable federal, state, and local pernite authorizing the development and operation of the TSD farility."

\section{FACILIFY REQURRMENT SOURCE: WAC-173-303(931208) Section 800( 0}

-The terms used in regand to permits which are not defined in WAC 173-305-040 shall have the serms masaings af set forth in 40 CFR 270.2."

\section{FACIITIY REQUIREMENT SOURCE: WAC-173-305(931208) Section 806( 4)(a)}

"(4) Coatents of Part B. Part B of a permit application slsoll consist of the information required in (a) through (i) of this sabsection.

(a) General requirements. Part $B$ of the permit application consists of the general information requirements of this stabsection, and the spexific information requirements in (b) through (h) of this subsection as applicable to the facility. The Part B information reguinements presented in (a) through (h) of this subsection, reflect the standards promulgated in WAC 173-303-600. These information requirements are necessary in order for the department to determine compliance with WAC 173-303-600 through 173-303-670. If owners and operators of TSD facilitiea cen demonetrate that the information prescribed in Part B cannot be provided to the exterc requined, the department may make allowturce for suberission of anch information on n case-by-case bastis. Information reguired in Part B stall be submitted to the department and

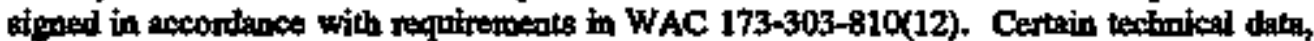
such as degipn drawings and specificalions, and engineering stasties shall be certified by a ragietered professional engineer. The following information is required for all TSD facilities, except es WAC 173-303-600(3) provides otherwise.

(i) A generil description of the facility.

(ii) Chemical, biological, and physical annlysea of the dangerous wasto to be handled at the facility. At a minimum, thess analyses shall contat all the information which must be known to treat, store, or dispose of the wastes properly in

(iii) A copy of the whate analysis plan required by WAC 173-303-300(5) and, if applicable WAC 173-303-300 (5)(8).

(iv) A description of the sesurty procedpres and equipment required by WAC 173-303-310, or n justification demonstrating the reasons for requesting a waiver of this requirement. (v) A copy of the genteral inspection schedule requited by WAC 173-303-320(2): Inchude where applicable, es part of the tospection schedule, specific requirements in WAC 173-303-395 (1)(d), 173-303-630(6), 173-303-640 (4)(a)(i) and (6), 173-303-650(4), $173-303-655(4), 173-303-660$ (4) and (5), 173-303-665(4), 173-303-670(7), and 173-303-680(3).

(vi) A justification of any request for a wrativer(s) of the preparedness and prevention 


\section{STANDARDS REQUIREMENTS IDENTHICATION DOCUMENT HIGH LEVEL WASTE STORAGE TANK FARMS \\ Environmental Protection \\ whC-20-0150}

requitrementy of WAC 173-303-340, or a description of the procedures used to comply with thees requirements.

(vii) A copy of the contingency plan requited by WAC 179-309-350: Inclade, where applitoble, pert of the contingency plan, specific requirements in WAC 173-303-640(7), 373-303-650(3) and 173-303-660(6).

(viti) A description of procectures, strisctures, or equipment used at the fecility to:

(A) Prevent haranda and contoin spills in unloading/londing operztions (for exomple, ramps, berms, pevement, special forklifts);

(B) Prevent run-aff from dengerous waste handling aness to other areen of the facility or enviponment, or to prevent flooding (for example, berris, dikes, trenchus);

(C) Prowent contamination of water suppliesp

(D) Mitigate effects of equipment failure and power outages; and (E) Prevent unctus exposure of personnel to dengerous wasto (for expemple, protective clothing).

(ix) A deseription of precantions to prevent actideatal ignition or reaction of ignitable, reactive, or incompatible wastes as required to demonstrate compliance with WAC

173-303-395 including documentation demonstrating complizncs with WAC 173-303-395

(1)(c).

(x) Traffic pattem, estimated volume (number, types of vehictes) and control (for example, show turns ecroes traficic lanes, and stacking lames (if appropriate); describo eccess road qurfacing and losd bearing capacity; show traffic control signals).

(xi) Seirmic risk consideration. The ownerfoperator of a proposed facility or expension of an existing facility shall identify the seismic risk zone in which the frocility is inteoded to be located. Whero stats or local meps are not available, United States Geological Survey Open Fila Report number 82-1033 may be used to identify seismic risk zones. The ownerioperator shall demoustrates thet the facility con and will be designed to resist seiswic frotmd motion and that the design is gufficieat to withstand the maximum horizontal aeceleration of a design earthquales specified in the demonstration.

(xii) An outline of both the introductory and continuing training programs by cwners of operstors to prepare persons to operate or maintxin the TSD facility in a safe manner as required to demorstrits compliance with WAC 173-303-330. A brief description of how training will be designed to meet achual job tajks in acoondance with requirements in WAC 173-303-330 (1)(d). (xiii) A copy of the closure plan and, where applicable, the post-closurte plan required by WAC 173-30s-610 (3) and (8). Include, where applicable, es pert of the plans, apecific requirements in WAC 173-303-630(10), 173-303-640(8), 173-305-650(6), 173-303-655(8), 173-303-660(9), 173-303-665(6), 173-303-670(8), and 173-305-680 (2) and (4). (xiv) For dangerons wasta disposal units that heve been closed, documentation that notices required under WAC 173-303-610(10) hrve been filed. (xv) The most recent clasure cost eatimate for the facility prepared in accortince with WAC 173-303-620(3) and a copy of the documentation required to demonstrate fingneial essurance umder WAC 173-303-620(4). For a new fixility, a copy of the required documeatation may bo sabmitted sixty days prior to the initial receipt of dangerous wastes, if that is later than the submission of the Part B.

(xvi) Where applicable, the most necent post-closure cost estimate for the fucility prepared in accordance with WAC 173-303-620(5) plus a copy of the documentation rexuired to demonstrate financial assorance under WAC 173-303-620(6). For a new fiseility, a copy of the reyuired docomentation miny be subunitted sixty days prior to the initial receipt of dangerous wastes, if that is later than the submission of the Part B.

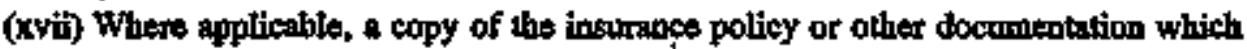
comprises complizmes with the 1 equirements of WAC 173-303-620(8). For a new filly, documentation sthowing the amount of insurance meeting the specification of WAC 173-309-620 (8)(a) 2od, if spplicable, WAC 173-303-620 (8)(b), that the owner or opentor plang to have in effect before initial receipt of dangerous waste for treatments storape, or dispocal. A request for a variagee in the amoint of required coverage, for a new or existing 


\section{STANDARDS REQUIREMENTS IDENTIFICATION DOCUMENT HIGH LEVEL WASTE STORAGE TANK FARMS \\ Environmental Protection \\ WHC-EP-6750}

fanility, may be submitted as apecified in WAC 173-303-620 (8)(c).

(xviii) A topographic map showing a distance of one thousand teot anound the facility at a scalo of 2.5 centimeters ( 1 inch) exual to not more them 61.0 meters (200 feet). Contours must be shown on the map. The contour interval must be sufficient to cleariy show the poittern of

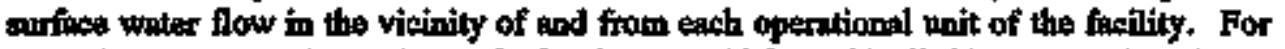

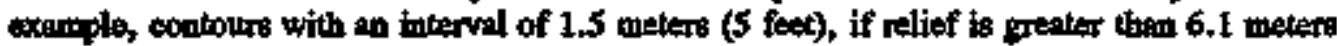
(20 feet), or an intervel of 0.6 meterg (2 fett), if relitef is less thin 6.1 weters (20 feet). Owners and operators of TSD ficilities locented in mountsinous artes thould use farge contour intervals to adequately show topoproptio profiles of ficilities. The map stall aleanly show the following:

(A) Map acola and dator

(B) One huadrsd-year floodplain area;

(C) Surface watere including intermittent etreams;

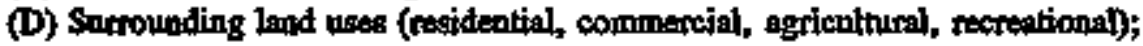

(E) A wind tose (1.t., prevaling windspeed and difection);

(F) Orientation of the urap (north arrow);

(G) Legal boundaries of the TSD faclity site;

(H) Acosss control (fences, gates);

(I) Injection and withdrawal wells both on-site and ofi-site; (D) Buildings; treakment, stomage, or disposal operations; or other strueture (recreation areas, run-off control systerm, access and interual roads, storm, souikary, and process sewerage systems, koading aod unload'mp areas, fire control ficilitiles, etc.);

(K) Barriers for dreinge or flood contral; and

(L) Location of operational mits within the TSD froility site, where dingerous wasto is (ot will be) treated, stored, or disposed (include equipmeat clean-up areas).

(Note - For large TSD facilities the department will allow the usa of other scales on a

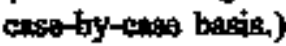

(xix) Applicants may be required to auburit such information as may be neceseory to erable the department to carry out its duties under odber state or federal laws as required.

(xx) Additional infomation requiremenk. The following additional information ragarding protaction of ground water is required from owmers or operators of dangerous waste facilities containing a regulated unit except as otherwise provided in WAC 173-303-645 (1)(b):

(A) A summary of the groumd water monitoring data obtained during the interim status period under 40 CFR 265.90 through 265.94, whers applicable; (B) Identification of the uppermost aquifer and aquifers hydrulically interconnected beneath the facility property, tuchuding groumd water flow ditrection and rate, and the besis for such tdentification (i.e., the tof formation obtained frow hydrogeologic investigations of the freility area); (C) $\mathrm{On}$ the topogeraphte mop required under (a)(xviti) of this aubsection, a delineation of the waste manageupent areen, the property boundary, the proposed "point of compliance" as defined under WAC

$173-303-645(6)$, the proposed location of ground water monitoring wells as requitred under WAC 173-303-645(8), and, to the extent possible, the information required in (a)(xx)(B) of this subsection;

(D) A description of any plume of contamination that has entered the ground water from a

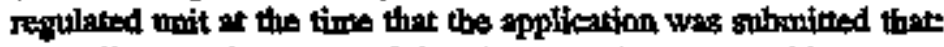

(I) Delineates the extent of the plume on the topographic nap requifed under (a)(xviti) of this sulbection;

(II) Identifiea the concentration of each constituent throughout the plume or identifies the meximum concentrations of each constibtent in the pitume. (Constituents are those listed in Appendix IX of 40 CFR Part 264, and any other constiturents not listed there which have eqused a managed waste to be regulated under this chapter.);

(E) Detailed ptans and an enginesing report describing the proposed ground water monitoring program to be implemenked to meet the requirements of WAC 173-303-645(8); 


\section{STANDARDS REQURRMENTS IDENTIFICATION DOCUMENT HIGH LEVEL WASTE STORAGE TANK FARMS \\ Environmental Protection \\ WHC-EP-0750}

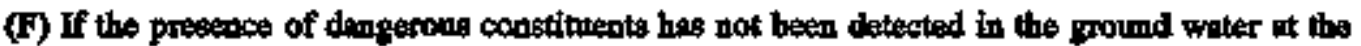

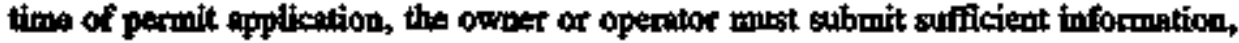

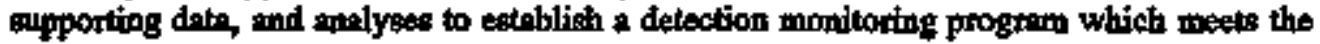
requirements of WAC 179-903-645(9). This submission must adkress the following itemo speoiffied under WAC 173-303-645(9):

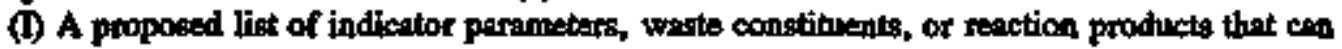
provitis a reliable indicetion of the presence of dangerous constitwents in the ground water; (II) A proposed ground water monitoring system;

(III) Beckground valus for each proposed monitoring parameter or constituent, or prosechureg to celculste such values; and

(IV) A description of proposed sampling, analysis and statistical comparison procedurea to be uilized in evalnating ground water monitoring data; (G) If the presence of dengeroug congtituents has been detected in the ground water at the point of compliance at the time of permit application, the owner or opesstor must submit sufficient information, aupporting data, and analysed to establish a compliance monitoring program which meets the requitements of WAC 173-303-645(10). The owner or operator must also suburtit an engineering fessibility plan for a corrective extion progerem necessery to meet the requirements of WAC 173-303-645(11) except provided in WAC 173-303-645 (9)(b)(v). Alternatively, the owoter or operator abtain written anthorization in advante from the department to submit a proposed permit sthedule for development and whmittal of such information. To domongtrate conolinace with WAC 173-303-645(I0), the owiner or operator mast address tha followitis items:

(I) A deccription of the wastea proviously handled at the facility; (II) A characterization of the contaminated ground water, tincluding concentrations of dangerous constibsents and paramaters; (III) A list of constitureots and parrmetes for which compliance monitorings will be undertaken In teochilance with WAC 173-303-645 (8) and (10); (IV) Proposed concentration limits for eech dengerous constitueat and parameter, based on the criterie set forth in WAC 173-303-645 (5)(a), including a justification for establisting any alternate concentration limits;

(V) Detailed ptans and an engineering teport describing the proposed fromd water morritoring system, in aceordaucs with the requitrements of WAC 173-303-645(8); and

(V) A deseription of proposed sempling, atalysis and statistical comphrison procedures to be utilized in sustuating grourd water monitoring data; and (H) If dengerous constituents or perameters heve been measured in the ground witer which exced the concentration limits established under WAC 173-303-645(5), Table 1, of if ground water montitoring conducted at the time of pernit wplication uniter 40 CFR 265.90 through 265.94 at the waste bourdary tidicentes the presences of dengerous constituents from the freility in grolind water ower beckground concentratione, the owner of operator must salbuit sufticient inforrietion, supporting date, and analyses to establish 2 corrective action program which mete the requirements of WAC 173-303-645(11). However, an owper or operator is not required to anbmit information to establish a concestive action program if he demonstrates to the department that alteralte concentration listits will protect butman besth and the environment after coosideting the criteria listed in WAC 173-303-645(5). An olver or operator who in not required in esteblish a corrective action program for this reason must instead submit sufficient information to establish a compliance monitoxing program whith weess the requirements of WAC 173-303-645 (ti) and $(\mathrm{a})(\mathrm{x} \times)(\mathrm{F})$ of this subsection. To demonstrate compliance with WAC 173-303-645(11), the owner or aperator must address, at a minitumin, the folloting itams:

(9) A characterization of the contaminated ground water, including concentrations of dangerous constituents and parametersy

(II) The concentration limit for each demgerous constituent and parameter found in the ground water as set forth in WAC 173-3034645(5); (III) Detailed plams and an engineering report describing the conective wetion to be taken; 


\section{STANDARDS REQUIREMENTS IDENTIFICATION DOCUMENT HIGH LEVEL WASTE STORAGE TANK FARMS \\ Environmental Protection \\ wic-EPMTso}

(IV) A diption of how the ground water monitoring program will demonstrats the adequecy of the carrective metion; aod

(V) The permit may conlain a schodule for submiktal of the information required in (a) $(x \times)(H)(I I)$ and (IV) of this subesction, provided tho owner or operatar abtains written anthotization from the department prior to submittal of the complete permit application. (zxi) Contingest gnound wates protection progrant. The following actions are required for owners of operatora of proposed land-based frepilities end may be required for owners/Operitors of existing land-based facilities, except is provided in WAC 173-303-645 (1)(b).

(A) Contingent grotud water protection program. The owner or opentor shall develop a contingent ground whter protection progrim. The purpose of this progitm will be to prevent the migration of dengerous whste or dengervus waste constiturents from triste manngement units to the nearest hydranlically downgradient neceptor at any time during the life of the fagility. For the pupose of this sulusection, the dowogradjent receptor shecll bo the farility property line, pereanial surfeco water or domestic well, whichever is poarest to the dangerous wasto management unit The contingeot ground water protection program shail at a minimum: (I) Defun the locil and regional hydrogeologic characteristics. The contingent ground wates protection program shall be based on a sufficient understanding of site geology, hydrology, and other factora to allow evaluetion of its adequacy by the department. Site characterization stall be performed in auficient detail to provido, at a minimmm, the following informestion Site geostratigraphy; site hydrostatignaphy; identification of aquifers, aquitards, and aquicludes; flow models for each stratum (i.e., ponts media or fruturre flow); the distritution of vertical and horizontal by treulic conductivity; offective poresity; horizontal and verticel hydrantic gradients; ground water trenvel tinte to reestors; and haterogeoeity for exch stratigraphic unit. Site interpretative models shall inchude ranges of tested values: The provisions of WAC 173-309-806 (4) $(\mathrm{a})(\mathrm{xx})$ and 173-303-645, siall be used as guidance in the davelopment of the contingent ground water protetion program.

(II) Identify the range of potential release scenarios that could occur during fecility operation and the pastelosure care period. The scedarios sball incorporate the intended destign(s) of the dangerous waste manigement utit(s), wastes to be placed in the dangercus whaste mingagement nnit(o), waste and laschate chemistry, waste, and soil and rook geochemical interactions, and the results of site characterization pursupnt to WAC 173-303-806 (4)(a)(xx) and (xxi)y (III) Inclade specific physieal action to be taken if dangerous waste or dangerous waste constituents are detected in one or more of the monitoring wells. The physical actions shall be based upon engineriog fessibility studies describing remedial actions establisbed from sito specific conditions and waste featires. Such actions may include installation of a pump and treat system between the monitoring well end the receptor or instillation of a section of slumy will to decresse ground water trevel times. The description of the systems shall also provido how the remediation system will achieve cleanup, its efficiency, and the timeframes involved; (TV) Incorporate the design, constraction, and sampling methods outlined in WAC 173-303-645 (8)(c), (d), (e), (O), and (g):

(V) Demonstrate to the satisfaction of the departirent that the otraefoperator of the dangerous waste menagement facility has the fingncial expability to implement the proposed gronod water protextion plan; and

(VI) Irclude reporting procedures to the department.

(B) The response tetionts titentified in WAC 173-303-806 (4)(a)(xxi)(A)(III) shall be activated if the presence of dangerous waste of dangerons waste constituents have heen detected at the point of compliagce ith recordance with WAC 173-303-645 (9)(g), and stall continue until the concentration of dangerous waste or dangerous wasto constituents under WAC 173-303-645(4) are reduced on levels bejow their respective concentration limits specified in WAC $173-303-645(5)$.

(C) If the owner/operator does not demonstrate that the ground water prolection program will 


\section{STANDARDS REQUIREMENTS IDENTEICATION DOCUMENT BIGH LEVEL WASTE STORAGE TANK FARMS \\ Environmental Protection \\ WHCEPro7s0}

paterent the migtation of dengerous waste or its constitutents to the nearest receptor, the department will require correction. to be inade in the protection program, increase sabecks from the nearest receptor, or deay the permit.

(xxii) Additional requitements for incineration facilities. The following actiond regardiog the protection of humen bealch and the environment wrust be talken by owners/operators of propoesd hexzrdous waste incineration freilities and may be required for owners or operntors of existing incineration fiscilities.

(A) Ambient monitoring program. The owner/operator shall be required to develop an ambient monitoring program. The purpose of this ambient monitoring program will be w: Gether bassline environmental infonmation characterizing on-site and off-site environmentsi cenditions prior to facility operation; and, to identify and measure changes in the environment which moy be linked to the construction and operation of the facility. The ambient monitoring program shall, at a minimim:

(I) Inciludo a charactorization of facility exission sources and pattoways of contaminant tromsport.

(II) Chancterize locol and regional ecosystems, including agricultural, end their sensitivity to the poteotial conteminsonts from the facility. (III) Incorporatb the findiogs of the envirommental

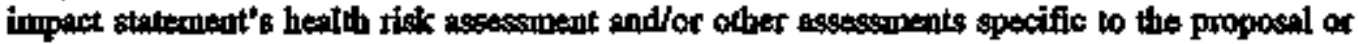
wvailable to the scientific commumity vegarding emissions from dangtrous waste management furilitiog and their potential humen health and exvironmental offects.

(IV) Ideatify sensitive indicator plants and animals for biomonitoring, identify specific chernical constituento of concern, sampling locations, sampling frequency, sampling and analytical methods, chatio of custady procedures, quality ussurzace/quality control procedures, reporting times, recordkeping procedures, and dath evaluztion procedures.

(B) Environmental review procedtures. The ownerioperator stafl establish procedurea to allow for public noview of fucitity operation and all monitoring date required by the facility's permis In developing this process, the ownerfoperator shall, at a minimurm:

(A) Coordinats this effort with the public and interested local organizations;

(II) Identify the informational needs of the community and devalop a public information process which mesta these reeds; and

(III) Develop procedures allowing full acosss by the public to all monitoring data required by the permit.

(C) Impact mitigation plan. Prior to the department issuing a permit, the owmer/operator shall aubuit en impuct mitigation plan witich dermonstrates to the satiefaction of the depertment thet the ownerfoperator will mitigato ell probable significant adverse impacts, including economic, dus to freility locetion and operations. The owner/operator shall wse as a basis for identifying

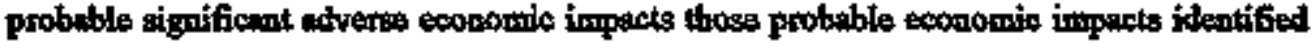

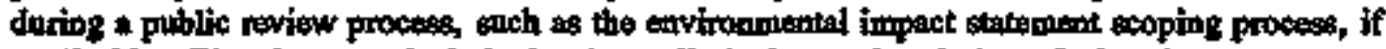
applicalhte. The plan must include, but is not limited to, a description of what the ownerfoperator will do to rechuce or prevent any probable significant impacta before they oceur, to miligato such impucts should they oceur, and to cnsure tho owrer/operator has and will have the financial capability to implament koch preventative and mitigative measures. Mitigation messures may include, ws an elerient, financial compensation to adversely affocted parties. This plan miy be eubritted with exvirommental reports the department reguires for complitone with the State Eavironmentell Polioy Act, with the written citizes propontent negotiation report and agreements, or with the Part B permit application. If the plan does not demonstrate that the owner/operator is capable of adequately mitigating the identified probable gignificant adverse economic impacts, the department will requirs modification of the plan or of the proposed fecility location, or will deny the permit application. The department must bo satisfied with the plan prior to the issuance of the permit.

(xriti) Information requirements for solid waste manggement units. (A) The following

information is required for each solid wasto manggement unit: 


\section{Environmental Protection \\ wherfortso}

(I) The location of the unit on the topographio nup required nader (o)(xvili) of this anbection.

(II) Desigarition of type of unit.

(III) Cenetal dimensions and etruetural description (supply any available drawings).

(IV) Tines frome over which the unit was operated.

(V) Specification of all wastes that have ben menaged in the trit, to the extent availuble.

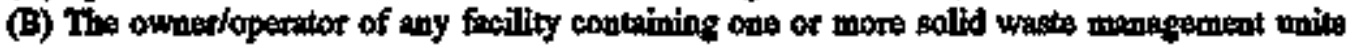
megt whomit at available informition pertining to any relense of dengerous wastes or dangerous constituents from ench unit or units.

(C) The owner/operator must condust and provide the regults of satupling and analyoie of pround whter, lendsurface, and gubsarface strata, surfece water, or dit, which may include the installation of welli, where the departoneat determines it is necessery to courolete a RCRA Facifity Asesesment that will determine if a more complete investigation in necessary.

WAC 173-301-806 (4)(a)(xriv):

(xxiv) Information requinemente for known releasas.

(A) The following information is required for any and all kmown releases of dangeroue waste and dangerous constibsents (as defined by WAC 173-303-646 (2)(c)) at the facility.

(I) The location of the release on the topographic map required under (a)(xviii) of this subeection.

(II) General dimencions of the release and any celovant structural description. For exaurple, if tho release is from a storage tank, provide a structural description of the tank. Supply any available drawings. (III) Tims frame over which the release occurred.

(IV) Specification of all dangerous waste or dangerous constibuents (as delined by WAC 173-303-646 (2)(c)) present in the reloase, to the extent available."

NETA

Subelement 18.3.4 eddresses the National Environmeatal Policy Act (NEPA), which establishes a mational policy to ensure that consideration is given to environmental values and factors in federal planning and decisionmaking. The DOE's policy is to comply fully with the

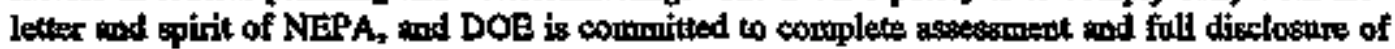
the environmental oojnsequences of its proposed activities.

NEPA ectivities arp routinely coordinated with Stato Environmental Policy Act (SEPA) activities for proposed ections requiring state or local agency permits or approvals. Stals or locel agency permits or approvals trigger the need for a SEPA review.

\section{FACILITY REQUIREMENT SOURCE: 10CFR1021 Part 200}

(a) DOB shall provide for adequate and timely NEPA raview of DOB proposels, including those for programs, policies, projects, regulations, orders, or legislation, in accordance with 40 CFR 1501.2 and this section. In tis planning for each proposal, DOB shall include adequate time and furding for proper NEPA review and for preparation of anticipated NEPA decuments.

(b) DOE shat begin it NEPA review so soon \& possiltle after the time that DOE proposes an action of is presented with a proposel.

(c) DOE shall determine the jevel of NEPA review required for a proposal tin mocotdence with Sec. 1021.300 and sibpart D of this part.

(d) During the development end consideration of a DOE proposal, DOE shall review any relevant planning and decision making documents, whether prepared by DOB or another agency, to determine if the proposal or any of its alternatives are considered in a prior NEPA document. If so, DOE shall consider adopting the existing document, or any pertinent part thereof, in eccordance with 40 CFR 1506.3." 


\section{STANDARDS REQUIREMENTS IDENTIFICATION DOCUMENT HIGH LEVEL WASTE STORAGE TANK FARMS \\ Environmental Protection \\ whe-ER-0750}

\section{FACILITY REQUIREMENT SOURCE: 10CFR1021 Pant 210}

(a) For eech DOE proposel, DOE sall coordinate its NEPA review with its decision making. Sections 1021.211 through 1021.214 of this part specify how DOE will coordinate its NEPA neview with decision points for certain types of proposals (40 CFR 1505.1(b)).

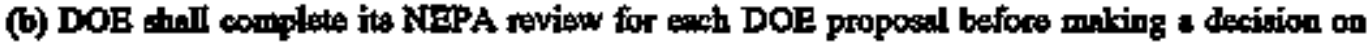
the propoeal (a.g., normally in atvance of, end for use in reacting, a decision to proceed with decoiled design), except as provided in 40 CFR 1505.1 and Secs. 1021.211 and 1021.216 of this pert.

(c) During the decision miking process for each DOE proposal, DOE shall consider the rolovant NEPA documente, publito and ggency comments, es part of its consideration of the propaens (40 CFR 1505.1(d)) and shall inchuds such documenks, comments, and responses as pout of the administrative record (40 CFR 1505.1(c)).

(d) If an EIS or EA is prepared for a DOE proposeal, DOE ehall consider the alterutives tonlyzed in thet EIS ar EA before rendering a decision on ther proposeal; the decision on the proposel shall be within the range of alternatives artalyzed in tho EA of EIS (40 CFR $1505.1(e))$.

(o) When DOE uses a brond dection (such as one on a policy or program) as a basis for a subseqpent narrowes deciaion (such as one on project of other site-specifis proposal), DOE may uso tiening ( $40 \mathrm{CFR} 15 \mathrm{O} 2.20$ ) and incorporation of material by reformco (40 CFR 1502.21) in the NEPA review for the subsequeat narrower proposal."

\section{FACILITY REQUIREMIENT SOURCE: 10CFR1021 Part 300}

(a) DOE shall determine, under the procedures in the CEQ Regulations and this pert, whether any DOE proposal:

(1) Requires preparition of in EIS;

(2) Requires preparation of an EA; or

(3) Is coporically excluded from proparation of ther an EIS or in EA.

DOE shatl prepsure any pertinent documents as requined by NEPA, the CEQ Regulations, or this part.

(b) Notwithatanding any other provision of these regulations, DOE may prepare a NEPA document for any DOE setion at any tims in order to further the parposes of NEPA. This may be done to enalyze the consequences of ongoing ectivities, support DOE planning, assesa the need for mitigation, fully diselose the potential environmental consequences of DOE actions, or for any other reason. Documenta prepared under this paragraph shall be prepared

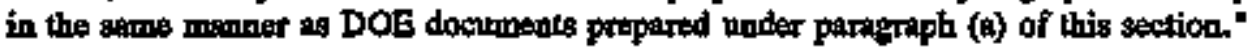

\section{FACILITY REQUIRBMIENT SOURCE: 10ChR1022 Part 3}

"Palicy

DOE aball exercitse leadership and take action to:

(a) Avoid to the axtent possible the long- and short-term atverse impacts essociated with the destruction of wetlands and the ocenpancy and usedification of poodpleins and wetlands, and avoid direct and indirect support of floodplain and wetlands developenent whenever there is a practical alternative.

(b) Incorponte floodplain mankgement goals and wetlands prokection considerationa into its planning, regulatory, and decisionmaking proesses, and strall to the extent practicable:

(1) Reduce the hazand and risk of flood loss;

(2) Minimize the inmact of floods on humin sefety, health, and welfare; 


\section{STANDARDS REQUIREMENTS DENTHICATION DOCUMENT BIGH LEVEL WASTE STORAGE TANK FARMS \\ Environmental Protection \\ Wheterso}

(3) Restore and preserve matural and beosficial valtues served by floodplains,

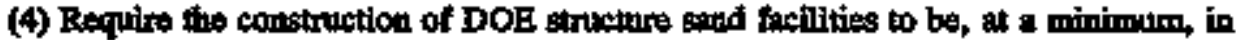
accordence with the etrintarits and criterta set forth in, and consistent with the tritent of, the reggilations promulgated by the Federel Insurence Administration pursurent to the Netiotol Flood Insurance Act of 1968, as amended, 42 U.S.C. 4001 et seq.;

(5) Minimizs the destruction, loss, or degredeticn of wetlands;

(6) Preserve and enhance the natural and beneficial values of wetlands;

(7) Promote public awareness of flocd bazards by providing conspicanus delintations of past and probable flood heights on DOE property which has suffered flood damage or is in an identified flood havard area and which is used by the general public; and

(8) Prior in the completion of any finencial transaction related to an area located in a floodploin, which is gurpenteed, approved, regulated or insured by DOE, inform any privute participating parties of the flood-raleted begrits involved

(c) Uniertite a correful evaluation of the potential effects of any DOE sefion taken in a floodplain and ang now construction undertaken by DOE in wetlands not loctated in is floodplatio.

(d) Identify, evaltation, and as appiopristo implement glternative actions which may avoid of mittigate adverse floodplain/wethonds impacts; and

(e) Provide opportunity for endy public reviaw of aty plans or proposals for actions in floodplotos and new construction in wetlands."

\section{FACILITY REOUREMENT SOURCE: 40CFR15\% Part 1501,2}

\section{-Apply NEPA Early in the Process}

Agencies sfall integrate the NEPA process with other planning the the earliest possible time to insure that plinniog and decisions reflect environmental values, to avoid delays later in the process, and on bead off poledtial canfikts. Epch agency shall:

(a) Comply with the mandate of section 102(2)(A) to "utilize a systematic, intertisciplinary approsch which will insure the integrated use of tha natural and social sciences and the envinonmental design arta in planning and in decision making which moy have an impact on mon's environment," as specified by 1507.2 .

(b) Identify environmental effecta and values in adequate detail so they can be compered to economic and technical analysis. Environmental documents and appropriate analysen shall be circulated and reviewed at the same time as other planning documents.

(c) Study, develop, and describe appropriate alternatives to recommend courses of action in any proposal which involves unresolved confliets concerning alternative uses of available regources as provided by section 102(2)(E) of the Act."

\section{FACILITY REQUERMENT SOURCE: 40CFR1500 Part 1501.4}

-1501.4 Whether to prepare an environmentol impset statement.

In determining whether to prepare an environmeatal impact statement, the Federal agtncy Bhal:

(o) Determine under its procedures supplementing these regulations (deseribed in Section I507.3) whether the proposal is coe which:

(f) Notmolly requites an environmedtal impuct atertentent, or

(2) Norm:lly does not tequire either an environmentel impact smotement ot at eovironmental 


\section{STANDARDS REQUIREMENTS IDENTIFICATION DOCUMENT EIGH LEVEL WASTE STORAGE TANK FARMS Invironmental Protection whe-ERTO}

mesament (cotesorical arciustion).

(b) If the proposed action is not covered by peraigriph (a) of this section, prepars an environmeatal assessment (Section 1508.9). The agency bhall tovive environmental ageneies, applifernts and the paitic, to the extent procticable, in preparing assessiments required by Seotion $150 \mathrm{~s}, 9(\mathrm{~s})(1)$.

(c) Rased on the environmeatel assessment make its determination whether to prepere an enviroqmentil impact statement.

(d) Commence the scoping process (Section 1501.7), if the egency will preparto and environmental impast statement.

(e) Prepans a finding of no aignificant impact (Section 1508.13), if the agancy determines on the basis of the envirunmental sssessement not to prepare a stetement."

\section{FACHLTY REQUIREMENT SOURCE: 40CFR1500 Part 2}

"Policy.

Fodesal agencies shall to the fullest extent possibles

(a) Interprest and adminicter the polinies, rtgulatious, and public laws of the United Stateg in accordance with the policies set forth in the Act and in these regulations.

(b) Implement procedures to meske the NEPA process more usefal to decisionmencers ind the publie; to reduce paperwork and the eccomnulntion of extraneous background datos and to emphagiza reel environmentil iestegs and altematives. Envircomental impact statements shall be conecise, cletr, and to the point, and stoull be supported by evidence that agencies beve made the neceserry envirommental analyses.

(c) Integrate the requitements of NEPA with other plaming and eavironmental review procedures required by law of by agency pratice so that all stich procedures run concurrently pother then constcatively.

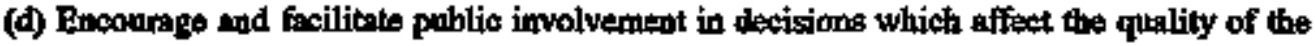
humen environment.

(e) Use the NEPA procesa to identify and assess the ressonable alternatives to propased actions that will evoid or mintmize adverse effects of these actions upen the quality of the humban environment.

(f) Use all precticable means, consigtent with the requirements of the Act and atber essentinl considerations of netional policy, to restore and enlaguce the quality of the bumant environment and svoid or minimize any possible eiverse effects of their entions upon the quality of the humen enviromment."

\section{FACILFY REOUIREMIENT SOURCE: 40CER15N7 Part 1}

"Compliance.

All ageacies of the Federal Government thall comply with these regulations. It is the intent of these togulations to aillow each agacy fiexibility in adapting its implementing procedures anthorized by $\$ 1507.3$ to the requitements of other applicible taws."

\section{FACHLIT REQUIREMENT SOURCB; 40CFR1507 Part 2}

"Ageocy capiobility to comply.

Ench ingeacy athll be capable (in terms of personnel and otber resources) of complying with the requirementis emimerated below. Such conpliance may include use of cther's resowrees, but the uing agency shall itself have strficient capability to evatuate what oflore do for it. Agencies shall:

(a) Fulfill the requirements of getion $102(2)$ (A) of the Act to utilize a systematic, interdisciplinary approach which will insure tho integrated use of the netural and axcinl 


\section{STANDARDS REQUIREMENTS IDENTIFICATION DOCUMENT BIGH LEVEL WASTE STORAGE TANK FARMS \\ Environmental Protection \\ WHC-ERPTSO}

sciences and the envinommentel dasign arts in plapning and in decisionmaking which may have to impact on the human eavironment. Agensiea

shall designate a person to be responsible for overall review of agency NEPA compliance. (b) Identify methodo and procedurea required by section 102(2)(B) to insure that presently unquentified envirenmental amenities and values may be given appropriate consideration. (c) Prepere adequate edvirunmeatal impect staternents pursuart to section 102(2)(C) and comment on stetements in the ereas where the agency has jurisdiction by las ar specisl expertise or is anthorizzed to develop and enforce environmental standards.

(d) Sudy, develop, and deseribe altennatives to recommended coursea of action in any proposal which fovalves unesolved conflicts concerning alternative uses of available resourses. This requitrement of bection 102(2)(E) extends to atl such proposals, not just the more limited scopo of section 102(2)(C)(tii) where the tiscussion of alternatives is confined to impact statements.

(E) Comply with the requirements of section $102(2)(H)$ that the agency initiate and utilize ecologieal information in the planning and development of resource-oriented projects.

(t) Fuffll the requitrements of sections 102(2)(F), 102(2)(G), and 102(2)(I), of the Act and of Execultive Onder 11514, Protection and Enhancement of Environmental Qurality, Sec. 2."

\section{FACILITY REQUIREMENT SOURCE: 40CFR1507 Part 3}

"Asency procedures.

(a) Nox later than ejght months after peiblication of these regulations finglly adopted in the FEDERAI, REGISTER, or five months after the establishment of in agency, whichever shinl come leter, each egency singll es necessary adopt procedures to sopplement these regulations. When the agency is a department, major subanits are encouraged (with the consent of the departiment) to adopt their own procedtres. Such procedures sball not paraphrase thess regulations. They strall confine themselves to implementing procedures. Each agency shall consult with the Coundil while developing its procedures and before publishing them in the FEDERAL REGISTER for comment. Agencies with similar programs should consult with each other and the Conncil to coordingte their procedures, especially for programin requesting gimilas information from epplicents. The procedurse shall be adopted only after an opportunity for public noview and after review by the Council for conformity with the Act and these regulations. The Cotncil shall complete its revtew within 30 days. Once in effect they shall be filed with the Council and made readily available to the public. Agencies are encournged to publish explenutory guidemce for these revulations and their own procedures. Agencies stisll continns to review their policies and procedures and in consultation with the Conncil to revise them as necesgary to tusure full conpitiences with the perposes and provisions of the Act.

(b) Agency procedures shatl comply with these regrilations except where compliance would be inconsistent with stontingy requitements and shall fuclude:

(1) Those procedures required by $\$ \$ 1501.2(d), 1502.9(c)(3), 1505.1,1506.6(0)$, and 1508.4.

(2) Specific criteria for and identification of those typical clesses of action:

(i) Which normally do require environmental impact statements.

(ii) Which normilly do not require éther an enviromental immact statement or an

enviroumental assessment (categorical exclusions (\$1508.4)).

(iii) Which normally rogaire envitummental assessments bat not nexessarily environmentel impert stotementit.

(c) Agency procedures may include specific critetin for providing limited exceptiong to the provisions of these regulatione for clessified proposels. Thy are proposed actions whish sate specifically authorized under criteria establisbed by an Executive Order or statato to be kept secret in the interest of nationel defense or forrign policy and are in fact properly classified purgunt to such Execulive Onder or statute. Environmental assessments ond environmental infrest statemente which address classified proposals may be safeguarded and restricted from pelalic dissemination in accordance with agencies' own regulations applicable to classified 


\section{STANDARDS REQULREMENTS IDENTIFICATION DOCUMENT HIGH LEVEL WASTE STORAGE TANK FARMS Environmental Protection whe-JP-0750}

informmition. These doctuments may be organized so thot classified portions cen be included of anoexes, in onder that the wuclassified portions can be made available to the pablic.

(d) Agency procedunes may provido for pextods of time other than those presented in \$ु1506.10 when necessiry to comply with other specific statutory reculinements.

(e) Agency procectures may provide that where there is a lengthy period between the agency'a decikion to prepare an envinonmental impact statement and the tims of actual preparation, the notice of intent required by $\$ 1501.7$ may be published at a reasonable tima in axtvance of preqaaration of the deaft stetement."

\section{FACILITY REQUIREMIENT SOURCE: DOES440.1E Preamble, Section 5}

Policy. NEPA established o ntitional policy to enstre that consideration is given to environmentel values and fastors in Federel plaming and decistonmaking. The Departuent of Eavery's policy is to comply fully with the letter end spirit of NEPA. To ensupe that envitontreat factors are considered in the decisionmaking process and in promole environmentelly responsible decisions, DOE will imcorporate NEPA requiremeats early in the planning process for proposed actions. DOE also will coortinate its NEPA activities with the states and tribes that host DOE actions. The Department ix committed to complete assessment and full disclostre of the exvirumentol consequetaces of its proposed actions."

\section{FACILITY REQUIRGMENT SOURCE: EO12114 Section 1}

\section{'ENVIRONMENTAL EFFECTS ABROAD OF MAJOR FEDERAL ACTIONS}

Pupase and Scope.

The parpose of this Executive Order is to enable responsible officints of Federal agencies

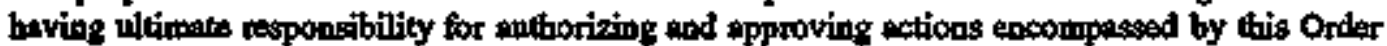
to bo informed of pertinent environmental considerations and to take such considerations into account, with other pertinent considerations of mational policy in maling decisions regarding such actions. While based on independent authority, this Order furthers the purpose of tho National Environmental Policy Ant and the Marine Protection Research and Sancharries Act and the Deepwater Port Act consistent with the foreign policy and national eecurity policy of the United States and represents the United Stotes government's exclusive and complete

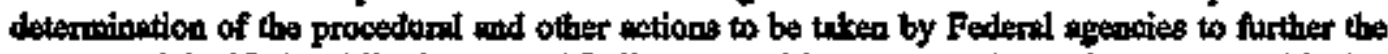
punpose of the Netional Environmettal Policy Act, with respect to the environment outside the United States, it territories and passessions."

\section{FACLLTI REQUREMENT SOURCE; BOt2114 Section 2 (1-4)}

\section{"ENVIRONMENTAL EFFECTS ABROAD OF MAJOR FEDERAL ACTIONS}

1. Aseroy Procedures.

Every Federal agency thing mijor Federal metions encompassed heneby and not exenuted here from having significant offects on the environment ontside the geagraghiol borders of the United Strtes and its territories and possessions shall within eight months after the offetive date of thia Order bave in effect procedures to implement this Onder. A Aetcies shall contsult with the Department of State and the Council on Esvironmental Qutality concerning such procedures prior to placing them in effect.

2. Information Exchange.

To nseist in effectuating the foregoing purpose, the Department of State and the Council on Envinonmental Quality in collaboration with other interested Federal agencies und other nations shall conderet a progran for exchange on a contiruing basis of informetion concerning the environment. The objectives of this program sholl be to provide toformation for use by decisionmakers, to heightsed awareness of and interest in environmental concesme and, an 


\section{STANDARDS REQUIREMENTS IDENTUFICATION DOCUMENT HIGH LEVEL WASTE STORAGE TANK FARMS \\ Environmental Protection \\ WEC-ER-0750}

spproptiats, to facilitete environmental cooperation with foreign natione. 3. Actions Included.

Agenciea in their prosedures under Section 2-1 shaill establish procedures by which thatr officese having ultimate responsibility for uthorizing and approving actiont in one of the following calegoriea encompassed by thir Order, take into considerotion in maling decinions concerning auch actions, a documpent described in Section 2-4(a):

(a) mojor Federal antiong significantly affecting the enviroument of the glohal commons antside the juristiction of any netion (e.g., the oceans of Antaretices)

(b) arojor Foderal actions significently affecting the environment of a foreign nation not pertiojpating with the United States and not otherwise involved in the action;

(c) mejor Federal entions significantly affecting the envirumment of a foreigh wation which provides to that netion:

(1) a product or phycical project produring a principal protuct of an emission of effluent which is prohibited or strictly regulaied by Fedoral law in the United Stated becanse its toxic effectr on the environment create a serious public beslth risk; or

(2) a phyrical project which in the United States in prohibited or strictly regulated by Federal Inw to protect the environment against radionctive substances.

(d) major Federal actiong outside the United States, its territories nnd possessiong whith sigmificantly offect natural or exological resourtes of global importance desipnated for protection under this oulbection by the President, or, in the case of stuch a respurce protected by internationd apreements bindiog on the United States by the Secretary of Stote.

Rocoumentations to the President under this subsection sholl be accompenied by the views of the Council of Environmental Quality and the Secretery of State.

4. Applicable Procedures.

(a) There are the following types of documeats to be used in connection with actions described in Section 2-9;

(i) eqvirommental impact atatemeats (including generic progtam and specific statements);

(ii) bitateral or multilateral environmental studies, relevant or related to the proposed action, by the United States and one mora foretpr nations, or by an international body or organization in which the United States is a member of participant; or

(iii) concise reviouts of the environmental, issues involved, including environmental assessments, stmmgry exvironmental malyses or other appropriate documents.

(b) Agencies shall in their procedures provide for preparation of documeats described in Section 2-4(a), with respect to wetions deseribed in Section 2-3 as follows:

(i) for effects dewriked in Sectinn 2-3(a), an environnental impact statement described in Section 2-4(a)(1).

(ii) for effecta described in Section 2-3(b), a documedt described in Section 2-4(a)(ii) or (iii), a determined by the egency;

(iii) for effects described in Section 2-3(c), a dowment described in Section 2-4(a)(ii) or (iii), as determined by the ageacy;

(iv) for effects deseribed in Section 2-3(d), a document described in Section 2-4(a)(i), (ii) or (iii), os determined by the atency. Such procedures may provide that an agency need not prepare a new document when a document described in Section 2-4(a) already exists.

(c) Nothing in this Order singll servo to involidate any existing repulations of any apency which hrve been adopted pursuant to count order or pursuant to judicial settemement of any case or to prevent any agency from providing in its procedures for messures tin addition to those provided for herein to further the pturpose of the National Environmental Policy Act and otber environmental laws, inchuding the Marive Protection Research moxl Senctuaries Act and the Deepwater Port Act, consistent with the forvifon and national security policies of the United States.

(d) Except as provided in Sextion 2-5(b), agencies taking action encompassed by this Order shall, ws soon as fensible, inform other Federal apeocies with rejevant expertise of the 


\section{STANDARDS REQUIREMENTS IDENTIFICATION DOCUMENT HIGH LEVEL WASTE STORAGE TANK FARMS \\ Environmental Protection \\ whe-glonso}

avilability of environmental doctoments prepared under this Order. Agemeies in their procedures under Section 2-1 shall motke appropriato provision for determining when an affected netion stail be informed in aceordanse with Section $\mathbf{3 - 2}$ of this Onder of the evailability of envirommental documents prepared pursuant to those procedures. In onder to evoid duplication of resources, agenciea in their procedures ahall provido for appropriate utilization of the rescuroses of other Federal agencies with relevant environmental jurisdiction or expertise:"

\section{FACILITY REQULROMENT SOURCE: SEM-NEPA Memo Paragraph 1}

Frell complinges with the letter fond spirtt of the National Environmental Policy Aet (NEPA), our national charter for protection of the enviroament, is an essential priority for the Departmert of Energy, consistent with our core velues. We are fully committed to pursuing excellence in all areas of environment, sefety, and health, including NEPA activities. The Departwent's openmess initiative underscores the need for public access to information and involvement in our actions. The NEPA process is a valuable planning tool and an opportumity to improve the quality of the Department's decisions and build public trust."

\section{FACILITY REQUIREMENT SOURCE: SEM-NEPA Page 1 Paragraph I}

The NEPA process is a valuable planning tool and provides an opportunity to improve the Departmeak's NEPA prograin have sthown that the Department mitst change the way it conducts lits business is avoid unnecessery delays and reap the foll benefits of the NSPA process. The Department must conduct the process as a team effort to make NEPA wort better and cost less. The following new polices will streamline the NEPA process, minimiza the cost and tims for document preparation and review, emphasizs teamwork, and make the process more usefil to decision makers and the pablic. Except where specifically indionited othenvise, these polices are immediately effective."

\section{FACILTY REOUIREMENT SOURCE: WAC-197-11 Section 960}

The State Environmental Policy Act (SEPA), chapter 43.21C RCW, rexpirs all govermmental ageocies to constider the euviroumental impacts of a proposal before mating decieions. An environmentsil Impact statement (EIS) must be preparsed for all proposals with probable significast adverse inpacts on the quality of the environment. The pupose of this checkltist is to provido teformation to help (applticents) end the agency identify inmpects from the proposel (and to reduce or avoid impacts from the proposal, if it can be done) and to belp the egency decide whether in EIS is required."

This elemert specifies the requirtments for pollution control reguletions, Ineluded ere groundwater quality standurds, iir quality standards inchuting air toxic releases, and rodiclogical release standards.

Water Onallify

This gubelemeat specifies the allowable groundwater quality stuntapis implemented the stals of Weahington.

FACLITY REQUIREMENT SOURCE: WAC-173-200 Section 040(3) and (3) 


\section{STANDARDS REQUIREMENTS IDENTIFICATION.DOCUMENT BIGH LEVEL WASTE STORAGE TANK FARMS \\ Environmental Protection \\ WHC-BPP0750}

"(2) The following criteria shall apply to all ground waters in the state of Washington:

(a) Ground water concentrations strall not exceed the criteria listed in Table 1, except as described in WAC 173-200-050(3)(0).

(b) For the primary and secoudary contantinants and rationuclides listed in Table 1, the criterin shell be the most stringent concentration of the following and thase listed in Table 1:

(i) Maxinmom confaminant level goals;

(it) Maxinalum contaminant levels; and

(iii) State maximum conteminant levels poblished in chapter 248-54 WAC as presently promulgated or subsecurently annended of repromilgated.

The criterin for primary and secondary conteminants and rediontelide contaminantr in Teble 1 ahall be amended as the federal and state rules are amended and without amendment of this chapter.

(c) For carcinogens listed in Table 1, the copteria are the concentrutions that are anticjpatod to

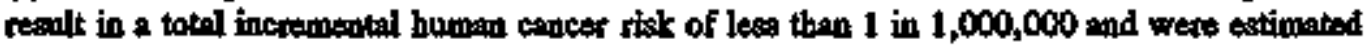
using the following equation and stadourd exposaus assumptions:

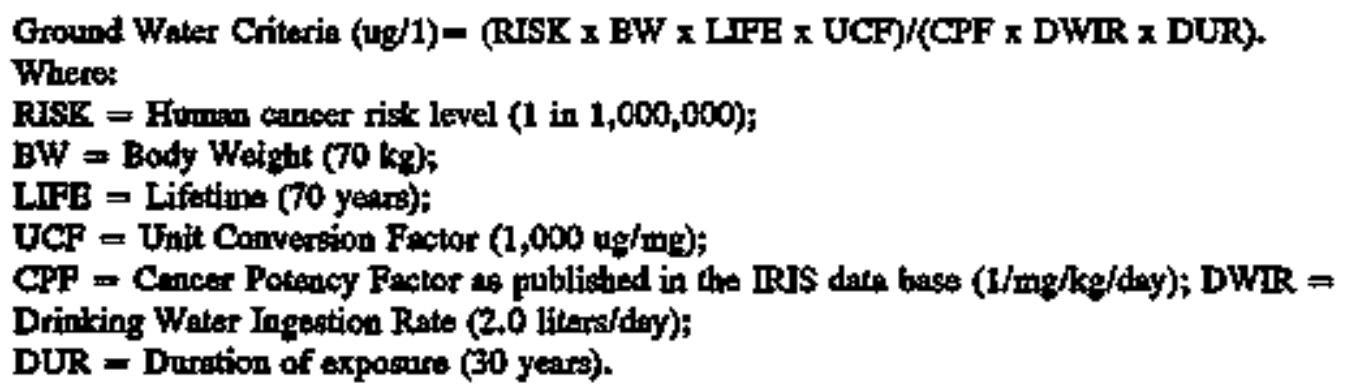

For volatile carcinogeng, inhalation exposure from showering was incorporated into the criteria by doubling the drinling water ingestion rate.

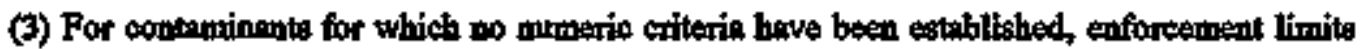
shatl be entablished in eccordence with WAC 173-200-050."

\section{FACILTY REQUREMANT SOURCE: WAC-173-303(931208) Section 645( 5)}

(5) Concentration limits.

(a) The department will specify in the fucillty permit concentrition limits in the ground wher for dengerous constituents established under subsection (4) of this section. The concentration of a dangerous constituents (i) Must not exceed the hackground level of that constituent in tho ground water at the time that limit is specified in the permit's of

(ii) For any of the constitureats listed in Table 1 of this aubsection, must not oxceed the respective value given in that table if the backgroued level of the conetibent is below the valute given in Talle 1; or

(iii) Must not exceod on alteroste linit established by the department under (b) of this sulbsection.

Table 1.

Meximum Concentration of Constiments

for Ground Water Protection 


\title{
Environmental Protection
}

WHC-ER-0750

\author{
Meximam \\ Constihvent Concentration1 \\ Arsenic 0.05 \\ Berinm 1.0 \\ Ceringium 0.01 \\ Chrominm 0.05 \\ Led 0.05 \\ Mentury 0.002 \\ Selenium 0.01 \\ Sitver 0.05 \\ Endrin 0.0002 \\ Lindane 0.004 \\ Methoxychlor 0.1 \\ Toxaphene 0.005 \\ 2,4-D $0.1 \mathrm{~m}$ \\ 2,4,5-TP Sitvex 0.0t \\ 1 Milligrams per liter."
}

18.4.2 Air_ouatity

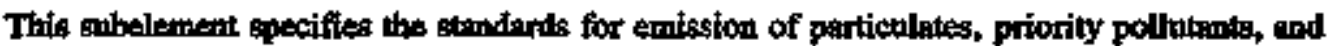
toxic chemicals to the amosphere.

\section{FACIITY RQQUIREMINAN SOURCE: WAC-173-400 Section 40}

Teaeral stendards for maximum emissions.

All scarces and emissions tmits are required to meet the emission standards of this chopterWhers an emission standard listed in another chapter is applicable to a specific emisetong unit, such standard will trike precedent over a general emission standard listed in this chapter. When two or more enissione units are connected to a comminh stack mod the operator elects nat to provide the meane or freilities to sample emissions from the tudividual emissions units, and the relative contributions of the individual emissions noits to the common discharge are not readily distinguighable, then the emissions of the common stack mast meet the most restrictive atendard of any of the connected emissicos wuits. Further, all emissions unitg are required to use nessanably avilable control technology (RACT) which way be determined for some sources or source categories to be more stringent than the applicable emisticn litititations of any chapter of Title 173 WAC. Where current controls are determined to be less then RACT, exology or the anthrrity shall, as provided in section 8, chapter 252, Lowa of 1993, define RACT for ench sonuce or sourte category and issts a rale or regulatory order requining the installation of RACT."

\section{RELATED RFFERENCES}

1. 10CFR20 Pent 1(c)

\section{FACILITY REQUIREMIENT SOURCE: WAC-173-460 Section 040}

\section{"New Source Review}

(1)(a) The owner or operator of a new toric air pollutant source tlited in WAC 173-460-130(2) ahall notify the authority prior to the construction, installation, or establishmeat of a dow toxic 


\section{STANDARDS REQUIREMENTS IDENTIFICATION DOCUMENT HIGH LEVEL WASTE STORAGE TANK FARMS \\ Envirommental Protection \\ WHC-EP-0750}

air pollutart source and shall file a notice of construction application with the authority for the proposed emission uni(4). Notification and notice of construction are nok required if the source is an exempt cource listed in WAC 173-460-030(3) or subsection (2) of this section."

\section{FACIITIY REQURREMENT SOURCR: WAC-173-460 Section 050}

Requirameant to Quantify Emissions

(1) Nestors.

(a) When applying for antice of construction, an owner or operator of a new toxic air

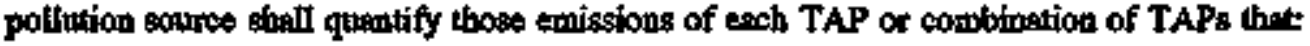

(i) Will be used for the modeling procedures in WAC 173-460-080; and

(ii) That may be discharged after applying required control technology. The information shall to submitted to the authority.

(b) Emissions shall be quantified in sufficient detail to determine whether the source complies with the requirements of this chapter."

\section{FACICITY REQUIREMENT SOURCE: WAC-173-470 Section 110}

Particle fallout thall not exceed the stindards enlumereted in the regulation. In recognition of naturel dust in artas of the state, exceptions are provided for wros east of the Cascode range crese"

\section{Badiological EPluents}

This subelement apecifies the standards for radiological releases. Guidance for monitoring of these roleases is specified in DOE/EH-O173T. DOE/EHO135 is a guidance doeument fond is not the sounce of enforcesble requirements.

\section{FACILITY REQUIREMENT SOURCE: 40CFR191 Part 3(a)}

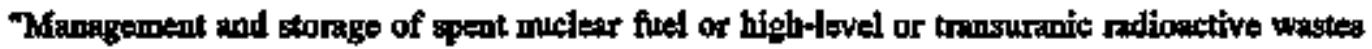
at all facilities regulated by the Connitsstom of by Agreement States strill be conducted in such a manner as to provide reasonable assurance thet the contbined ancual dose equivalent to ary member of tho public in the geanral enviromment resulting from: (1) Discharges of radionctive material and direct radiation from such management sad storago and (2) all operations coverid by Pant 190; stall not exceed 25 millirems to the whole body, 75 millirems to the thyrotd, and 25 uillitrems to any other critical atgan."

\section{FACILITY REQUREMENT SOURCE: 40CFR61 Part 92}

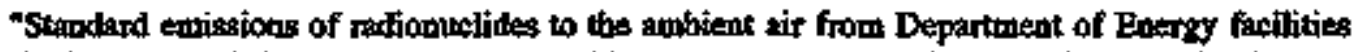
shall not exceed those alootants that would canse any meinber of the pliblic to receive in eny year an offective dnse eqquivalent of $10 \mathrm{~m}$ rem/yc.

\section{FACILITY REQUIREMENT SOURCE: DOE/EH0135 AX.2.18}

"All radionctive relewses aro ovatueted agoinst ALARA program abjectives to determine real 


\section{STANDARDS REQUUREMENTS IDENTIFICATION DOCUMENT HIGH LEVEL WASTE STORAGE TANK FARMS \\ Environmental Protection \\ WHC.EPT750}

population exposurea, "

FACIMTY REQUIRGMENT SOURCE: DOE/EH0135 AX.2.4

-A periodic roview of radioactivo effluent records is pesformed to determino trends and to detect discharges axceading established limits."

\section{FACILITY REQURRAMENT SOURCE; DOE5400.5 Chapter II, Section 1.a}

-DOE Publis Dase Limit - All Exposure Modes, All DOE Sources of Radiation. Except as provided by II.1.e.(4), the exposure of mismbers of the public to tatiation sources is a consequence of all routino DOE activities shall not canse, in $A$ year, an effective dose equivalent greater then 100 metem ( $1 \mathrm{mSv}$ ). Doss ovaluations should pelfect realistic exposurs conditions."

\section{FACIIITY REQUIRRMENT SOURCE: DOE5400.5 Chapter L, Section 1.b}

"Airbome Emissions Only, All DOE Sources of Radionuclides. To the eftent required by the Clean Air Act, the exposure of members of the public to radiosctive materials released to the atmophere as a consequence of routine DOE activities shall not cause menthers of the putpic to receive, in a year, en effective dose exuivalent greater than $10 \mathrm{mrem}(0.1 \mathrm{mSv})$. Expasures to, sod ralenses of, ration-220, rudon-222, and their respextive decay products are subjest to DOB limits (See Figurt III-3 and Chapter IV, 4.b. and 6)."

\section{FACILITY REQURRMENT SOURCE; DOE5400.5 Chapter II, Section 1.b(I)}

Titis 40 CFR Part 6t. The public dose limits as outlined in Chapter $\Pi$, 1.b, are established by EPA negulation 40 CFR Part 61, Subpart H, mder the anthority of the Clesn Ait Act. These limits apply offsite whene the members of the public reside or abide. Subparts $Q$ and $T$ provide radon flux limits for DOE radium storage and disposal facilities (Chapter IV) and DOE invetive uranium mill teillings sites regulated under 40 CFR Part 192."

\section{FACILTY REQUIREMENT SOURCE: DOES400.5 Chapter II, Sextion 1.b(2)}

-AIRDOS/RADRISK Coder. To demonstrate complianco analytically with air emissions for the Clean Air Act Standards, dosed to the individuals shall be svaturted using the verstion of AIRDOS/RADRISK bown as CAP-88 or, when available and approved, ARDOS-PC. Other computer codes or models, stsch "Comply Code," which ane specifically approved in accordance with 40 CFR Part 61, moy also be used."

\section{FACILTY REQUIREMIWT SOURCE: DOE5400.5 Chapter I, Section 1.d}

"Dinking Watror Pathwry Only. All DOE Sources of Rudionuclides. It is the policy of DOE to provide a level of protection for persons consuming water from s public drinking water sapply operated by the DOE, either directly or through a DOE contrator, that is equivalent to thet provided to the pulilic by the public commanity drioking watter standerds of 40 CFR part

141. These systems shall not canse persons copasuming the water to noceive at effective dose 


\section{STANDARDS REQUIREMENTS IDENTHICATION DOCUMENT HIGH LEVEL WASTE STORAGE TANK FARMS \\ Environmental Protection \\ WHC-EP-Onso}

oquivalent greater thrn 4 rem $(0.04 \mathrm{mSv})$ in a year. Combined ratium-226 and radiom-228 atinil not eroeed 5E-9 micro Ci/mL and gross alphs activity (including adium-226 but oxcluding radon and urmium) shall not exceed $1.5 \mathrm{E}-8 \mathrm{micro} \mathrm{C} / \mathrm{mL}$.

(1) DOE Driaking Weter Systems. The dose limit is consistent with the drinting water eriterie in 40 CFR Part 141, "National Interim Primary Drinking Water Regulations (Safe Drimiting Water Act)."

(2) Dase Coopponents. The dose limit is the effective dose oquivalent to individuals whose

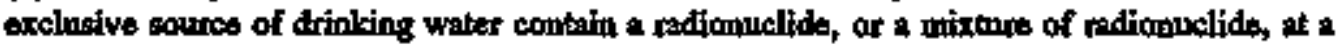

monthly everage tovel of four perced of the appropritte DCG velue. For simplicity, it is assumed that sito wotkers aro also exposed to four percent of DCG values of the ratifum and grose alphe lovels in II.1d for drinking water while away from the DOE site.

(3) Inpalot on Other Systems. The liquid efftuents from DOE activities shill not cause private or publit drinting witer systems downstream of the farility discharge to exceed the drinting water redioloyical limitg in 40 CrR Part 141."

\section{FACILTTY REQURREMENT SOURCE: DOES400.5 Chapter IV, Section 6.b(2)}

"Controts sinall be designed such that Rn-222 concentrations in the atmosphero above fiectity aurfuee or openings in addition to background levels, witl not exceed:

(a) $100 \mathrm{pCl} / \mathrm{L}$ at any gived potits

(b) An annual average coucentration of $30 \mathrm{pCi} / \mathrm{L}$ over the factity sites and

(c) An annul average concentration of $3 \mathrm{pCiL}$ at or above any locetion outside tho focility site.

(d) Fhr rates from the stotage of radon producing wastes shall not exceed $20 \mathrm{pC} / \mathrm{sq}$-Ir as required by 40 CFR Part 61."

\section{FACILTY REQUIREMIFNT SOURCE: DOBS400.5 Chapter IV, Section 6.b(3)}

"Controls shall be designated such that concentrations of radionuclides in the groundwater and quantities of resithal tufioartive mattertal will not exceed applicesble Federal or State standards."

\section{FACIITY REQURREMINTT SOURCE: WAC-173-480 Section 40}

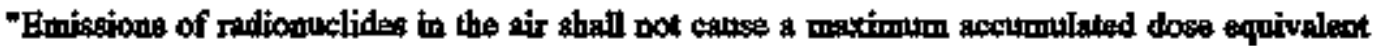
of more than $25 \mathrm{rem} / \mathrm{y}$ to the whole body or $75 \mathrm{rem} / \mathrm{y}$ to a critical orgon of any member of the public. Doses doe to radon-220, nadon-222, and their respective decay products aro excluded from these limits. Compliance with the standard shall be determined by procedures in WAC 173-480-070."

\section{FACILTY REQUHEMAKT SOURCE: WAC-173-480 Section 50}

"(1) All ndionuclide enviscion woita are required to met the emisston stondards in this chepter. At a mintmem, all emission tmits bhall meet WAC 402-10-010 requiring every resonable effort to meintain radiogctive materials in effluents to unrestricted areas, as low as rensonably whievalite (ALARA). For the purposes of this chapter, control equipment of 


\section{STANDARDS REQUIREMENTS IDENTIFICATION DOCUMENT HIGH LEVEL WASTE STORAGE TANK FARMS \\ Environmental Protection \\ WHC-EP-0750}

fucilities operating under ALARA shall be defined as ressonably availmble control technology (RACI).

(3) Whenever anotuer Federal or \$reto regulation or limitation in tffect controls the enissina of radipulutides to the antient air, the mare etringent control of emissious aball gavern."

\section{FACILITY REQUIREMINT SOURCE: WAC-246-290 Seetion 310(8)}

(b) The MCLs for radium-226, nodium-228, and gross alpha particle rediosctivity are as followis:

Radium-2263 pCiLL.

Combined Radium-2025 pCi/

and Radium-228

Groes alpha particle1s pCi/L

wetivity (exchuding uranium)

(c) The MCL for beta ond photon rationctivity from mon-made radionuclides is that the everage annuel conceutration atral wot producs an snmugl dose equivaleat to the whole body or any intemal organ greator than four millirem/year.

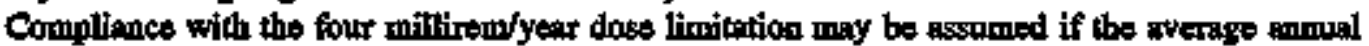
concentration for grass beta activity, tritium, and strontium-50 are less than $50 \mathrm{pCh}, 20,000$ $\mathrm{pCi} / \mathrm{L}$, and $8 \mathrm{pCi} / \mathrm{L}$ respectively, provided that if both radionuclides are present, the sum of

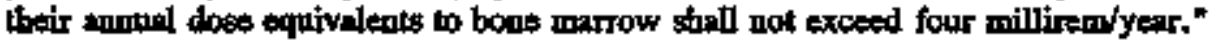

\section{POLLUTION PREVENTION}

This element qpecifies requirements for pollution prevention including controla for source reduction, preparedness and prevention, and handling of

The Pollution Preveation element inchudes controls for source nextaction reporting, recycling, and wasto mimimization.

\section{FACIMIMY REQUMREMENT SOURCE: DOE/EHOI35 TS.5.1}

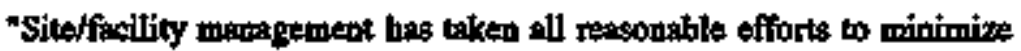
quantities of radipactive and hazardous mutertals released to the envirenment from aite/Fecility operation."

\section{FACILITY REQUIREMENT SOURCE; DOE5000,3B Attachment I, Group 2}

A. Radionuelids Relesseg

\section{Emersency}

(a) Any relense of radionuctide material to controlled or uncontrolled areas in concentrations which, if avernged over a period of 24 hours, would exced 5 times the rexpetive reportible quantities (RQs) specified for such materials in 40 CFR 302.

\section{Unustal Oceurrence}

(a) Relense of a radtonuclide material that axceeds a Federally permittad releese by the

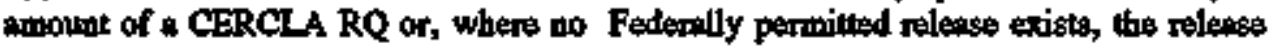




\section{STANDARDS REQUIREMENTS IDENTIFICATION DOCUMENT HIGH LEVEL WASTE STORAGE TANK FARMS \\ Environmental Protection \\ WHC-EPOHO}

axcesds the RQ.

(b) Release of radiomuclide material that violatea environmental requirements in Federol permitta, Feilenl regolntions, or DOE standarda.

(c) Release balow Emergency levels which rexuires immediate ( $<4$ hours) reporting to Federal regulatory muthorities or triggers specifio action kovels for an outside Federal agency.

Off-Nornal

(a) Any release of redionmelide material to controiled or uncontrolled areas that lo not purt of a normal monitored release end exceeds 50 percent of a CERCLA RQ specified for such moterial per 40 CFR 302.

(b) Any controlled releese of radfonuctide material that occurs as a wountored part of nomil operations whikh exceeds what historical date and/or analyzis show is expected as a result of normal opentions.

(c) Any monitored facility or site boundary where exposure or concentrations exceed whet historionl data and/or anolysis show is expected as a resalt of wormal operations.

(d) Any delection of a radionuclide in a sanitary or starm sewser, waste or procese diram, or any bolding points where such a material is nox expected.

(o) Any controlled, uxoutrolled, or accidencal relesse which is bot classified as an Unusun Oecurnesce but which will be reported in writing to State/local ageocies in a format otber than routine montlly or quartedy reports.

B. Relesse of Hazardou Substances/Rtgutated Pollumats/Oil

Throughout this Order and particularly within this sub-Group, reporting of spills of releeses of ethylene glycol and glycol ethers shall be finited only to those spills or releases in excess of 100 pounds.

\section{Emergency}

(a) Any actinal of potential release of meteriel to the exvironment that results in or cowld resenlit

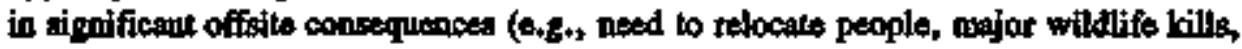
mojor wetland degradation, major equifer contamination, ueed to secture downstream water supply intakes, etc.).

(b) Any refese of hagardous substances or regulated pollatonts in concentrations which exceed firo times the respectivo RQA specified for such waterials in 40 CFR 302.

Umugual Ocountenco

(a) Release of a hamerdous substance or regulated pollutant that exceeds a CERCLA RQ per $40 \mathrm{CFR} 302$ or areds a fedemlly parmitted release by an $R Q$.

(b) Release of a hapardous allbstance, regulated pollatant, or oil that violates environmental requinements in Fedecal pernits, Federal regutations, or DOE stapdards. 


\section{STANDARDS REQUIREMENTS IDENTIFICATION DOCUMENT \\ HIGH LEVEL WASTE STORAGE TANK FARMS \\ Environmental Protection \\ WHCET-9750}

(c) Roleaso below Emergency level that requines immediats ( $<4$ hours) reporting to Federal regulntory agencied or triggen specific action Isvels for an outside Federil agent.

(d) Any releass of 100 gallons of mare of oil.

OfFNorm:1

(2) Releass of a hazandous gubstance of regulsted pollutant to controlled or tuncontrolled arean that is not part of a tormel, wornitoned trejese and exceeds 50 porcent of a CERCLA RQ $\approx$ epecifited for such muterial per 40 CFR 302.

(b) Any release of Oil less then the Unusural Ocentrence level but $>10$ gallone.

(c) Any detection of a toxic or hamardous substance in a sanitary or storm sewer, whaste or process strans, or any holding points where such a material is not expected.

(d) Any controlled, uncontrolled, or becidental relesse which is not classified as an Uunganl Octurrease but which will be reported in writing to State/locel gagencies in a formest other than routime monthly or guprorty reports.

(e) Any controlled release of hagardous/regulated material that occurs as a monitored part of normal operntions which exceeds what historical data and/or analysis sbows is expexted as n result of normal operations.

(f) Any geueral environmental monitorist whers contentration increases to level which enceeds what historical dath andfor analysis shows is expected as a restilt of nompoil operations.

C. Discovery of hazandous meterial contaminetion dus to DOE operations.

Emercency

(a) Discovery of contamination that results of covild result in significent consequences (i.t. oxceeding sofo exposure limits to workers or public).

(b) Discovery of onsits of offsite hayardous material contaminations in concentrations that exceed 5 times the respective $R Q$ s specified for such materials in 40 CFR 302.

Unustal Ocurmence

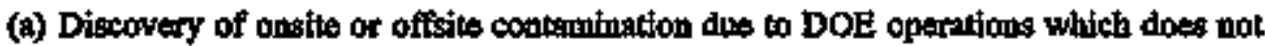
mepresent en immediato theest to the public, thar arceeds a reportable quartity for aluch materials per 40 CFR 302 .

(b) Any discovery of groundwater contamination that is not part of an existing plime previously identified ia either an anmual report or in any CERCLA/RCRA activity or report.

Off-Nomal

Discovery of onsito coptarrination atributable to DOE operatinns thas exceeds 50 percent of a reportable quantity for such moteriat per 40 CFR 302.

D. Ecological Resources 


\section{STANDARDS REQULREMENTS IDENTIFICATION DOCUMIENT FIGH LEVEL WASTE STORAGE TANK FARMS \\ Environmental Protection \\ WItc-BP.0750}

\section{Dinomal Occurrence}

Ary occurrense cansing significant impact to nny ecological resource for which the DOB is a

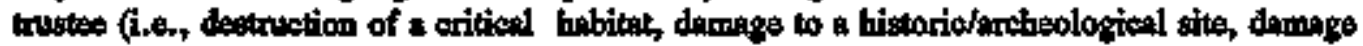
to wetlinids, ate.).

\section{E. Agroement/Compliance Activities}

\section{Unurusl Decurrence}

(a) Any agneement, compliance, remediation, or permit-mandeted octivity for which formal notification hes been received from the relevant regulatory agency that a site plan is not satisfactory or that 2 site is considered to be in nomcompliance with schectules or requinements.

(b) Any occurrence under any agreement or compliance area that requires notification of an outside regulatory sgency within 4 hours or less, or triggers an outside regulatory agency ection level, or otherwise indicates specific interest/concern from such agencies.

\section{Off-Normal}

Any occurrence under any digrement or compliadte aree that will be reported in writing to outside agencies in a format other than routint monthly or quarterly reports."

\section{FACILITX REQUIREMGNT SOURCE: WAC-173-160 Section 500(5)}

"Cuttings and development water shall be mangged in a manmer consistent with the intent and purposes of the Water Pollution Control Act, Chipter 90.48 RCW, the Hazirdous Waste Mansgenent Act, Chapter 70.105 RCW, 2nd implementing togulations (Chapto 173-303 WAC)."

\section{REOUIREMENT AUTHORITY}

1. ANS8.7/ANSIN16.5 Section 5.12

\section{RELATIKD REFERENCES}

1. 40CFR61 Part $14(d)$

\section{FACILITY REQUIREMIENT SOURCE: WAC-173-303(931208) Section 340(1)}

"Fantlities shall be destented, constucted, maletained and operated to minimize the possibitity of firs, explosion, of any unplanoed sudden or nonsuddea release of dangermus wasto or dengerous wrste constituents to air, soil, or surface of ground water which could threaten the public health or the ervironment. This section describes proparations and preventivo measares which help avoid or mitigate such situations.

(1) Required equipment. All facilities mest be equipped with tho following, unless it can be demongtrated to the department that none of the hazands posed by wasto handled at the facility could require a partivular hind of equipment specified below:

(a) An infernal communications or alarm system capable of providing immediate emergency instruetion to fucillity personnel; 


\section{STANDARDS REQUIREMENTS IDENTHICATION DOCUMENT HIGH LEVEL WASTE STORAGE TANK FARMS \\ Environmental Protection \\ Wikcteperso}

(b) A device, ach * telephons or $a$ bend-held, two-way ratio, capuble of summoning

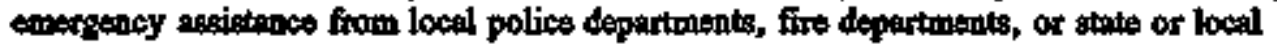
onsergency response teams;

(c) Portable fire extinguishess, firs control equipment, spill control equipment, and decontomination equipanents and

(d) Water at adequate vohume and pressure to apply water bose streams, form producing equipment, ontomatic aptiakless, of water bpray systems. All facility communicationg or alarm systeme, fire protection equipment, spill control equipment, and decontanization equipmeat, where required, must bo tested and maintained ag nexessary to assure its proper operation in time of emergency."

\section{FACIITY REQUIREMIENT SOURCE; WAC-173-303(931208) Section 340(2)}

"(2) Access to commonicationg or alnrms. Personnel must have immediate access to the sigzallfing devices described in the situations below: (a) Whenever dangercus waste is being poured, mixed, epread, or otherwise bandled, ill personnel involved must have immediate secess to an internal alarm or emergency communiantion device, either directly or through vifual or woice coatact with ancther employes, unless such a device is not nequired in subsection (1) of this section;

(b) If thene is ever just one employee on the premises while the facility is operating, be must

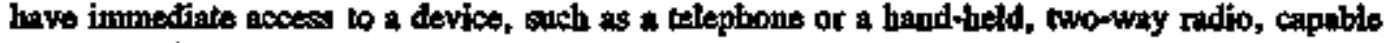
of summoning external emergency assistance, unless such a device is not required in subsection (1) of this section."

\section{FACIITY REQUREMAENT SOURCE: WAC-173-303(931208) Section 340(3)}

"(3) Aisłe spuce. The owner or operator must maintain aisle space to sllow the unobetructed movement of persunmel, firs protection equiporent, spill control equipment, and decontamination equipment to any ares of facility operation in an emergency, nniess it can be demonstrated to the depertureat thet aisle space is not neected for any of these purposes."

\section{FACILITY REQUTEMENT SOURCE: WAC-173-303(931208) Section 340(d)}

"(4) Arrangemente with locel muthorities. The owner or operator shall altempt to make the following arrangements, appropriats for the type of wasto bondled at his fincility and the potential need for the services of these orgenizations, miles the hezarils posed by wasteg bendled at the fecility would not requits these arrangements:

(a) Arrangements to familtiarize police, five departments, and emergency response teams with the layont of the facility, properties of dengerous waste handiled at the facility and associated bazarits, places where focility personnel would norwally be working, entranses to and roeds froide the fanility, and posstble evectuation routes;

(b) Arrengements io familterize locel hospitiss with the properties of dangerous wasto handled at the fircility and the types of injuries ar itlnosses which could resalt from fires, explostions, or meleasea at the facility;

(c) Agnemints with state emergency response trams, emergency response contractors, add equipment suppliers; and

(d) Whero more than ons party might respond to an emergency, agreements designating primary emergency withority and agreements with any others to provide support to the primary emergency althority."

FACILTY REQUTREMENT SOURCE: WAC-173-303(9312018) Section 340(5) 


\section{STANDARDS REQUIREMENTS IDENTIFICATION DOCUMENT HIGH LEVEL WASTE STORAGE TANK FARMS \\ Environmental Protection \\ Whe-EP-M50}

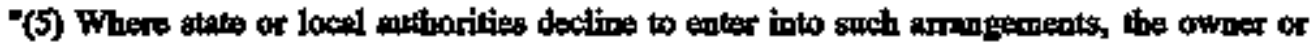
operator must docelment the refusel in the operating record."

\section{FACLITY REQUIREMENT SOURCE: WAC-173-307 Section 030 WAC Plans Part} (1)

"(a) A written policy articulating management and corporate support for the plan and a commitment to implement planned activities and achieve established gosts.

(b) The plan scope end objectives.

(c) A description of the facility type, a description of product(B) made and/ or services provided, and a statement or listing of the current lovel(s) of production or service entivity in units of meagure appropsiate to the industry or activity:

(d) A generil overview of the processes used in production or service activities (a schematic drwing may be included);

(e) A stetement providing, for the last calendar year, the fotal pounds of extremely hazardout

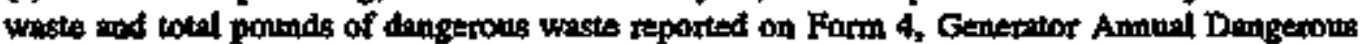
Weste Report, end, if applicable, the tosal pounds of toric relessed reported en Form $\mathbf{R}$ under SARA Title III, Section 313; and

(f) A description of curnent neduction, recycling, and treatment sctivities and dncumentotion of haverdious substance use reduction and hazandous waste reduction efforts completed prior to the first plan due date specified in WAC 173-307-050. Cearly separete the explamations of rectuction setivities from recycling and other management activities.

\section{FACIIIY REQUIREMENTr SOURCE: WAC-173-307 Section 030 WAC Plans Part} (2)

Part two shall incInde en identifiestion of hazardous substances used and hazardous wastea generated by the facility, a description of tha facility processes, an identification of rechuction, recycling, and trentment opportunities, an evaluntion of those opportunities, a selection of proposed options, a policy to prevent shifting of rists, performance gonls, and an implementution sohedula. Specifically, Part two sball inaludet

(a) An ideotification of products contrining harrordons stbstances used aod hazurdous wastes generated. This in to be based on actual ueage and geoperation during the mast recent calendar year for which recorils are aveilable. This task can be accomplished by choosing one of two spprosches. The approackes are ideatified as the "pound epprosch" and the "percentage approach." Look at the following descriptions and requirements of exch of these and determine which one you wish to use.

(i) "Pounds approach."

This approach requires you to identify the types and amounts, in eitber weight or volume, of hamrdou waste generated and products containing hazardous substances used up to these threshold levels:

(A) All dangenous waste strang five hundred pounds or greater, any smallex dangerous wasto 


\section{STANDARDS REQUIREMENTS IENTIFICATION DOCUMENT HIGH LEVEL WASTE STORAGR TANK FARMS Environmental Protection whe.ppo7s0}

stresmg which indivituslly represents ten percent of more of the total anousl barardous wentes, and all extramely hroindous waste streams subjest to regulation by the department. If this combination equiln less then nizety percent of the total havardous wastes generated, then additional dengerous wastes geaterated at the facility shall be included until ninety percent of tho totel is resched; and

(B) Eech product used which contains a total of fifty perceat or more of any combination of harmdous subatances if coe thousand pounds or more was used; each product used which coukins a totol of between twenty-five percent and forty-nine percent of hasordous gubstances if four thousand pounds of unore was used; and each product used which contains a total of between the and twenty-four percent of hazerdous substances if ten thousand pourda or more was used Any product which contains lass than ten percent of any hayrordous substances need not be included in the liet regatdless of the amount of the product used.

(C) Office products and products which are used at the faility for nooprocess rontine jantiotiol or grounda nutintenance retated activities maybe excluded from this list.

(D) Harardous aubstances used and hazardous wastes generated in laboratory research need not bo listed. Note: See Part two, ( $)$ of this subsection for discussion on this issur.

(i) "Percenthge' approunch-

This approach requires you to identify the types and amounts, in either weight or volume, of hazridous waste genenated and products containing hazardous substances used up to these threahold leswels;

(A) All extremely hazarious waste and enough additional dangerous wasto to reach ninety percent of all the haroutious weste generated; and

(B) Ninety percent of all the products used which conmin hemordous suhstences. This selection of protucts should attempt to include those that contain the highest concentrations of hazarinus gulbetances and the most inxic hazardous aubgtances.

(C) Office products and products which aro used at the facility for nouprocess routios fantitorial or grounds maintenence relaind activities may be excluded from this list.

(D) Homardou aubstances used and hazardous wastes generated in labomatory reseanch need not be listed. Noter See Part two, (k) of this subsection for discussion on thit issus.

(iii) Determinationg of whether these quantities are met or exceeded for either approsech shall be based on tho best avadlable tifformetion. This tiformation may be included or referenoed in the plan. Availeble finformation may include any or all of the following as necescary to decermine quantities of bazardious substances contained in products; information araiteble firom moterial sofety date sheetw, information fumished upon request from maqufacturers of guppliers of hazardous substances or products containing hazardous aubstances, information ohtained from the department, and information otherwise known by the frecility owner or operstor.

An explanation of the procedures used to determine that the thresholds were met or exceeded must be included in this section of the plan. 


\section{STANDARDS REQUREMENTS IDENTIFICATION DOCUMENT HIGH LEVEL WASTE STORAGE TANK FARMS \\ Environmental Protection \\ WHCEP-A7s0}

(iv) The above threfolds shatl only be used for plans required to be completed prior to Septarnber 2, 1996. Plans of plan updates completed from that date on must identify tho types

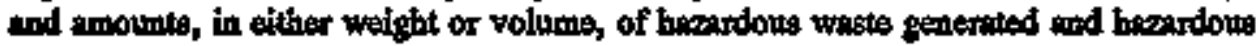
substomees tored top to the following threshold levels;

(A) The "pounds approuch" cen only be used for identifying hapardous wasto after September 2. 1996. This approach cannot be used for products containing havardous substances. The thregholdis for hazardous waste ane:

All dengerous waste streame five hundred pounds or greater, any smaller dangerous wasto streeme which individually represents tea pereent or more of the total annual havardous wastes, and ofl oxtremely hazarious waste streams subject to regulation by the department. If this combination equals less than ninety-five percent of the total havardous wastes generited, then edditional dengerous wastes generated at the fracility shall be included until ninety-five pencent of the total is rected.

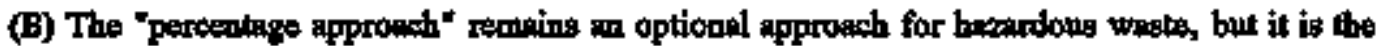
only approach that cen be used for products. The threstrolds for this approach are:

Alt extremely barincous waste and enough edditional dangercus waste to reach nimety-five pentent of all the bepardoug wasto generated; and

Ninety-five persent of all the produets used which contain hazardous substanes.

(C) The exemptions in sobitems (C) and (D) of item (ii) of this subdivision remgin in effect.

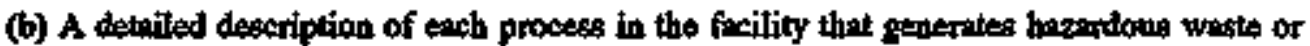
uses products contrining humodous gubstances as identified in the chosen spproech in (a) of this subsection. This description may include a schematic drawing.

(c) For the horsardou wasto and products containing hazarious substances identified in (a) of this gubsection within each of the processes identified in (b) of this eubeection, in identification, besed on thorough reseanch, of all reasonable opportunities for further harrordouta substance use reduction, hasordous waste reduction, recycling, and trealmert. Thorough research ghatl inchude, at a minimum, a review of literature commonly available to that inchutry or trade. The full range of potentially feasible opportunities is to be identified without regerd to possibls inmediments to implementing the opportunities. In ideatifying opportunities, consideration shall be given to alternative approaches which, in the jodgreenk of the fecility management, satisfy the anme demand for end products or services but use substantially less hazardous substano or result in the generation of substantially less hazardous wreste;

(d) An evaluation of the identified opportanities. Opportunities that be grouped by priority and avaluated ceording to the priorities. The priorities fre, in descending order: Hazandous

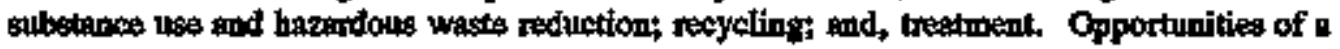
lower priority thall be gived consideration maly after a determination is made that fis bigher

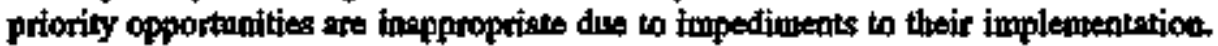
Impediments that shall be considtered acceptabie include, but are not litmited to: Advarse impacts on product quality, legal or contractual obligations, economic and technical precticality, safety considerations, and the creation of sutsctantial new risks to human health or the exvironment. 


\section{STANDARDS REQUIREMENTS IDENTIFICATION DOCUMENT HGH LEVEL WASTE STORAGE TANK FARMS Buvironmental Protection WRC-ER-0750}

Except with repect to the osa and distribution of fertilizers or pesticides inteaded for commarcial agriculutral epplieations, the evaluation of hazardcous waste reduction opportmilies must include in evaluation of hampilous sulustence use reduction opporturitites for those

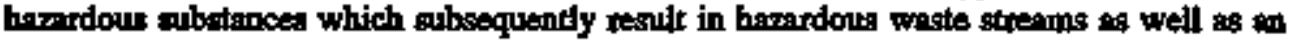
evaluation of other opportunities for the reduction of harardons waste.

The ovalmotion reyputed under this subsection stall inchude an economic malysis, a technical eveluation, an identification of whesber, and if so bow, the ideatified opportumity would rasult in 2 ahifting of tiek(s) from ane part of a process, environmentil medinm, or product to another and an identification of all impediments to implomenting the opportumities. The economic anelyris shell seck to identify the total costs aesociated with the thrrent bastardous substance use and hazandows waste genterition, managemsnt and disposol, compared with comparable costs associated with implementing the altermatives.

Evaluation of each opportunity may be considered complets when tenough information is available to select or reject the opportunity for implementiotion. For opportunities rejected, the reason(s) for rejecting them shell be stated.

(e) A selection of opportumities to be implemented in acoorithnes with the evaluption coraducted in (d) of this aubsection. For esch selected opportunity, the process(es) it affecto shall be identified, and extimates of the amount, by weight, of the reduction of hazardous subatances or products containing hazardous substances and harardous waste rechection whith would bo echieved through implementation shall be stated, es well as the emount of hamardous waster recycled or treated as a result of implementation shall be included;

(f) A written policy stating that in inpletneating the selected options whentever technically and economically practicable, risks will not be shifted from one part of a process, environmental medium, or produset to another;

(g) Specific performance goals in each of the following categories, expressed in mumerito torms:

(C) Hpzardous substances or products containing bazardous substances to be reduced or eliminated from uses

(ii) Hezardous wastea to bo reduced of eliminated through barandoug waste rechection techriques;

(iii) Materials or hazzondous wastes to be recycled; and

(iv) Harrirdous wasteg to be treated.

If the establishment of numaric performance goals is not practicable, the porformines goals shall include a clearly stated list of objectives designed to lead to the establistument of utmeric goalg as soon as is practicedle. Goals shall be set for a five-year period from the first reporting date (ses (h) of this subsection regarding implementation activities that will take longer then nive years);

(h) A fivo-year implementation schedule, which shall displey planned implementation activities for exch of the five calendar years following compietion of the plan. Information to be provided hall indude, but is not limited to, the opportunities (or phases of opportmities) 


\section{STANDARDS REQUIREMENTS IDENTIFICATION DOCUMENT HIGE IEVEL WASTE STORAGE TANK FARMS \\ Environmental Protection \\ WHC-EPotso}

being inplemented and related milestones. Where complete inmlemeatution of a selocted opportunity will take longer than five years, the schedule sball contain relevant milestones within a five-year period and an estimated date of completion. The schedule may be in table form and orgunized by opportunities within processes, if desired.

(i) A description of how those herardous wastes that are not recycled or treated and the residues from reycling and treatment processes are manged may be inctuded in the plan.

(D) Documentation of any research conducted in fulfillment of any of the above subdivisions of this subsection ahall be svailable to the department upon request.

(t) For research baboratories, the plan may include, in lien of all the detailed requiremeats of this enbection, a dascription of policies and procedures to be followed by laboratory personnel regarding the use of hazardous sabstances and the generation of hazardous wastes through Inboralory research. These policies and procedures must be consistent with the waste reduction priorities as defined in this chiptor."

\section{FACILITY REQUREMIWNT SOURCE: WAC-173-307 Section 030 WAC Plans Part} (3)

"(3) Part three. Part three shall provide a financial description of the plan, which shall identify costs and benefits reslized from implementing selected opportinities to the extent reasongbly possible. Part three shall also include a description of accounting system which will be used to identify hrzardous substance use and hazardous waste manngement costs. Liability, compltance, and oversight costs must be components of these sconoting systems."

\section{FACILTYY REQUIREMIENT SOURCE: WAC-173-307 Section 030 WAC Plans Part} (4)

"(4) Part four. Pant four of the plan shall include a description of personnel trining and employes involvenseat programs. Eacti facility requited to wite a plia is excouraged to advise its employees of the planning process and solieti conments or sugpestions from its enoloyees on harardous gubstante use and waste reduction opportinities. [Stantory Authority: Chapter 70.95C RCW. 91-20-131 (Ordar 91-35), 173-307-030, filed 10/1/91, effective 11/1/91; 91-03-04I (0rder 90-57), 173-307.030, filed 4/1/91, effective $5 / 2 / 91]$.

RECORDKFEPING, REPORTS AND NOTIFICATIONS

This element addresses controls for records, contents of these records, daration for maintaining these records, lifetime clessification, quality desiguation and dispossition of records.

18.6.1 Water Onality

This aubelement specifies requirements for maintenance and control of effluent discharge and surfice water quality data collected under State and Federal water quality monitoring prograng.

\section{FACIITY RDQUIREMENT SOURCE: WAC-173-160 Section 50(1), Sentence 1}

"Every well contrator, within thirty days after completion of a well, is requined to submit a camplete record on the construction or alteration of the sell to the department." 


\title{
STANDARDS REQUIREMENTS IDENTIFICATION DOCUMIENT HIGH LEVEL WASTE STORAGE TANK FARMS \\ Environmental Protection \\ whe.
}

\section{FACIIIY REQUIREMIENT SOURCA: WAC-173-160 Section 560}

- (1) If it can be verified that a resource protection well wes constructed in eccondance with these regulations, it ehall be abandoned by filting the casing from the bottom to the ence with grout or bentonite. If the construction cennot be verified, the well strell bo bindoned in wordance with WAC 173-160-415(2).

(2) The abandomment prodedire shell be recorded on a form provided by the depurtment and thall include, a a mirimum, the following informstion: project anme, if appropriate; date; location of well by $1 / 4,1 / 4$, section or smallest legal stbdivision; well identification number; use of well; method of setting the plug; type and amount of sealant used; and stech alditional information ss required by the department.

(3) The well abandonment most be recorded and reported to the departmeant within thirty days of abandonment.

\section{Air Opality}

This aubelement epecifies the standards for maintenanee and control of ambient air and emissions data collected under State and Federal air quality monitoring programs. The requirements specified from 40CFR265. 064 apply only to those waste tank system managing wastes with greater than 10\% by weight organies.

\section{FACILITY REQUIREMENT SOURCE: 40CFR265 Part 1064}

\author{
Recordkeeping Requirements
}

(a)(1) Each owner ar opterator abject to the provisions of this subpart shall comply with the recond reeping requiremente of this subpert.

(2) An owner or operator of moro than one hazardons waste mamagement unit sabject to the provisions of this subpart may comply with the recordkeeping rexpirements for these hazasdous waste manggement unito in one recortreeping system if the system identifies each record by each hazaridous waste management unit.

(b) Owpers or operators must record the following information in the facility operating recond:

(1) For euch piese of equipment to which subpart BB of part 265 appilies:

(i) Equipment identification number and hazardous waste management unit identification.

(ii) Approximate locations within the facility (o.g. identify the bazardous management unit on a faciltty plot plan).

(iii) Type of equipment (a.g., a purmp or pipeline valve).

(iv) Percent-by-weight totel organics in the bezurdous waste stream it the expipment.

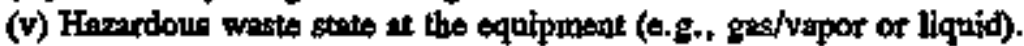

(vi) Method of complinnce with the atandard (e.g., "monthly leak detection and repoir" or "equipped with dual mechanical seals").

(2) For facilities that comply with the provisions of

265.1033(日) $(2)$, on implementation schedule as specified in

265.1033(日)(2).

(3) Where an cowner or operitor chooses to use test data to demonstrits tho orgonic rempovil 


\section{STANDARDS REQUIREMENTS DENTIFICATION DOCUMENT HIGH LEVEL WASTE STORAGE TANK FARMS \\ Environmental Protection \\ WHC.MP.0750}

officiency of total organtic compomed consentration actioved by the control device, a performence test plen as specified in 265.1035(b)(3).

(4) Documentation of compliance with 265.1060, irclading the detaited desipen documentution or performance lest resulta specified in 265.1035 (b)(4).

(c) When each lesk is detected as spesified in 265.1052, 265.1053, 265.1057, and 265.1058, the following nequirements apply:

(1) A weatherproof and readily visible identification, marked with the equipmeat identification rumber, the dote evidense of a potential leals whe found in weordines with 265.1058(a), and

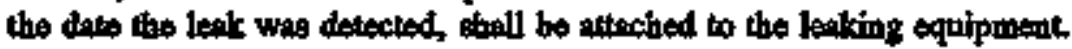

(2) The identificution on equipurent, except on 2 valve, why be nemoved sfiter it hae beed reppired.

(3) The identification on a valve may be removed after it has been monitored for 2 sucosesive months as kpecified in 265.1057(c) and no lesk bas been detaxted furing those 2 monthe.

(d) When each leat' is deteded apecified in 265.1052, 265.1053, 265.1057, and 265.1058,

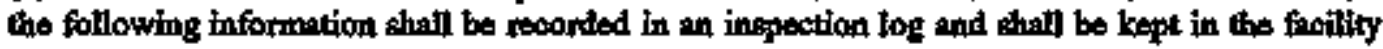
operesting record:

(1) The instrumeat and operator identification numbers and the equipment identification number.

(2) Tho date ovidence of a potential lenk was foumd in accordance with 265.1058(a).

(3) The date the leak was detectrd and the dates of each nttempt to repair tho leak.

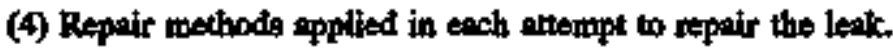

(5) "Above 10,000" if the maximum instrument reading measured by the methods spectifted in 265.1069 (b) after each repair altempt is equel to or greater than $10,00 \mathrm{ppm}$

(6) "Repatr delayed" and the reason for the delay if a leak is ant repaired within 15 calendar days aftor discovery of tho leak.

(7) Documentation apporting the delay of repair of a valve in compliance with 265.1059 (c).

(8) The signature of the owner or operator (or designom) whose decision it whes that repair could not be effected without a hoverdons wasto manigement unit shutifown.

(9) The arpected date of successful repair of the leat if a leak

is not repaired within 15 calendar days.

(10) The date of successfut repair of the leat.

(a) Desige documentetion and monitoring, operating, and inspection information for each closed-vent system and control device required to comply with the provisions of 265.1060 shalf be recorded and kept up-to-date in the faeility operating record as specified in 265.1035 (c). Design doenmentation is specified in 265.1035(c)(1) and (c)(2) and monitoring, opereting, and 


\section{STANDARDS REQUIREMENTS WENTIFICATION DOCUMENT FIGH LEVEL WASTE STORAGE TANK FARMS \\ Environmental Protection \\ WHCER-OThO}

inspection information in 265.1035(c)(3)-(c)(8).

(f) For a contol dovice othes than a thermel vapor incinerator, catalytic vapos incinerotor, flore, boiler, process hester, condeneer, or ceatron stsorption syotem, monitoring and inspection information indicating proper operation and maintentonce of the control devite must be recorded in the fecility operation recond.

(9) The following informetion pertaining to all equipoment subject to the requirements in 265.1052 through 265.1060 shall be recorded in a log that is kept in the fucility operating recourd:

(1) A list of identification numbers fos equipment (except welded fittings) anhject to the requirements of this sulpeart.

(2)(i) A list of identification numbers for equipment that the owner or operator elects to desipmate for no detectablo emissions, es indicated by to instriment reading of less then 500 ppin above backeround, undar the provisions of 265.1052(e), 265.1053(i), and 265.1057( $)$.

(ii) Tho designation of this equipment ss subject to the requirements of 265.1052(e), 265.1053(i), and 265.1057(f) shall be siged by the owner or operator.

(3) A list of equipment identifieation numbers for pressure relief devices required to comply with 265.1054(a).

(4)(i) The dates of each compliance test requited in 265.1052(e), 265.1053(i), 265.1054, and 265. $1057(f)$.

(ii) The backgromd level measured during each compliance test.

(iii) The maximum instrument seding messured at the equipment during each complience lest.

(5) A list of ideatification numbers for equipment in vactum service.

(h) The following information pertrining to all valves subject to the requirements of $265.1057(\mathrm{~g})$ and $(\mathrm{b})$ shall be recorded in $\mathrm{a} \log$ that is kept in the forility operating record:

(1) A list of identification numbers for valwes that are designated as unsafo to monitor, an explanation for each valve why the valua is unsate to monitor, and the plan for monitoring each valve.

(2) A list of identificotion unmbers for vitves that are desigrated as dificult to monitor, an explanation for each valve stating why the velve is diffictilt to monitor, and the planned schectulo for moritoring each valve.

(i) The following information shall be recorded in the facility opexating recond for valves complying with 265.1062:

(1) A schedule of monitoring.

(2) The pencent of valves found leaking during each monitoring period

(j) The following information shall be racorded in a $\log$ that is kept in the facility operating 


\section{STANDARDS REQUIREMENTS IDENTIFICATION DOCUMENT HIGA LEVEL WASTE STORAGE TANK FARMS \\ Environmental Protection \\ WhC-Fip-0750}

recond:

(1) Criterit roputed in 265.1052(d)(5)(ii) and 265.1053(e)(2) and an explanation of the criterit.

(2) Any changes to these criteria and the ressong for these changes.

(k) The following information sball be coconded in a log that is kept in the facility operating recond for use in determining exemptions as provided in the applicability section of this subpart out otber specific subparts:

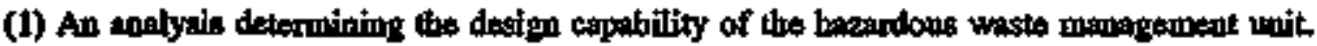

(2) A staterrent listing the hazrritous waste influent to and effluent from each hazaribus waste mrmagement unit aubject to the rexuirements in 205.1052 through 265.1060 and an anslysis determining whether these hazardous wastes ape hesvy liquids.

(3) An ap-to-date analyais and the supporting information and datz used to determine whether or not equipinent is abject to the requirements in 265.1052 through 265.1060. The record shall include supporting documentation as required by 265. 1063(d)(3) when application of the knowledge of the nuture of the hazarions waste stream or the process by which it was

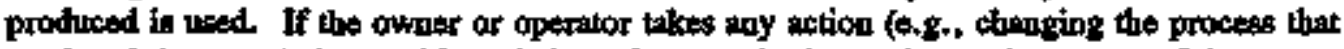
produced the waste) that could rescult in an increase in the total orgenic content of the waste contsined in or contacted by equipment determined not to be subject to the requirements in 265.1052 through 265.1050 , then a new determination is required.

(1) Recond of the equipuneat leak information required by parsigraph (d) of this section and the operating information required by paragraph (c) of this section need be bept only 3 years.

\section{FACILITY REQUIREMENT SOURCE: 40CFR61 Part 14(0)}

"The owner or cperator shall msintain records of momitoring data, monitoring system calibration checks, and the cocurrence and duration of any period during which the monitoring system is malfumctioning or inoperative. These records shall be maintained at the sourcs for a minimum of 2 years and mede available, upen request, for inspection by the Administrator."

\section{FACILITY REQUIREMENT SOURCE; WAC-173-490 Section 105}

"(1) the owner of optratme of a stationary source listed in a source category of WAC 173-400-100 shall upon notification by the director, maintain reconds on the type and quabtity of entissions from the source and other informetion deemed necesesy by the ditector to determine whether the source is in compliance with applicable emiseton limitetions and control meessures,"

Fapardous_Materigls

This subelemant specifies the standards for maintenance and control of hamardous material inventory deta collected undar State and Federal "right-to-tmow" programs, and UST records sond reporting.

FACILITY REQUIRGAENT SOURCE: 40CHR355 Part 40(b)(I) 


\section{STANDARDS REQUIREMENTS IDENTIFICATION DOCUMENT HIGH LEVEL WASTE STORAGE TANK FARMS \\ Environmental Protection \\ WHC-AP0750}

"Notice Requirements. The owner or operator of a facility subject to this section shatl

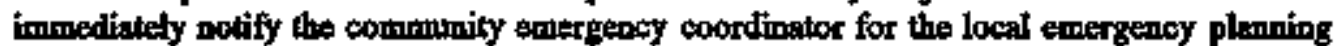
committee of any ares likely to be affected by the release and the State emergency responso commission of any State likety to be affected by the release. If thene is no local emergency plaming commiltee, notifieation shall be provided under this section to relevant local emergency response personinel."

\section{FACLITY REQUIREMENT SOURCE: 40CFR370 Part 21(a)}

"Bustc Requiteaneat. The owner or operator of a facility atbject to this Sathpart shall suthmit an MSDS for arreh hassardous chamical present at the facility acconting to the minimum threshold schedule provided in paragraph (b) of szetion 370.20 to the committee, the commission, and the fire department with jurisdiction over ths facility."

\section{FACILITY REQUIREMENT SOURCE: 40CFR370 Part 25(a)}

Baste Rexuirement The oumer of operator of a facility gubject to this Sutpart shall submit an inventory form (Tier II) to the commission, the committee, and the fire department with jurisdiction owes the factlity."

\section{BACIITY RDQUIREMENT SOURCE: 40CFR372 Part 30}

"(a) for each toxic chemical known by the owner or operator to be manufactured (including imported), processed, of otiturwise used in exces of an applisable threshold quantity in Section 372.25 at its covered facility described in Section 372.27 for a collendor year, the ownes or operator must submit to EPA and the State in which the faciltity is located a completed EPA Form R (EPA Form 9350-1) in pecondance with the instructions in Subpart E."

\section{FACILIY REQUIREMENT SOURCE: WAC-173-360 Section 210(1)}

(1) Reporting. Owners and operators shall submit the information specified in (a) through (c) of this substion to the department or delegated agency:

(a) Notification for all UST systems (WAC 173-360-200), which includea certification of installation for now UST eystems (WAC 173-360-305(5));

(b) Reports of all suspected relesses (WAC 173-360-360), confirmed releases (WAC 173-360-372), and spills and overfills (WAC t73-360-375);

(c) Reports required for contuctive action under chapter 173-340 WAC;

(d) A notification before pertingent closure of change-in-service (WAC 173-360-385); and

(6) Ths appropriate forms certificates of compliance, and evidence of financial responsibility (WAC 173-360-446).

(f) Checklist required for tank service activities, site checks, ard sits assessments shall be suburitted by tank services providers or persons registered to perform site checks and sito assessments, as applicable."

\section{FACILITY REQUIREMONT SOURCE: WAC-173-360 Section 210(2)}

'(2) Recordkeeping. Owners and operators shatl maintain the following information:

(a) Documentation of operation of corrosion protection equipunent (WAC 173-360-320); 


\section{STANDARDS REQUTREMEONTS IEENTIFICATION DOCUMENT HGH LEVEL WASTE STORAGR TANK FARMS \\ Environmental Protection \\ WHC-ERTASO}

(b) Documentation of UST system repairs (WAC 173-360-325(7);

(c) Recent compliances with relense detection requirentents (WAC 173-360-355);

(d) N/A

(e) Corrective wetion records in accordance with chapter 173-340 WAC;"

\section{FACILITY REQUIREMENT SOURCE; WAC-173-360 Section 210(3)}

"(3) Availsbility ond maintengnce of records. Owners and operators shatl keep the records rocutived eiltort:

(a) At the UST site and immediately available for inspextion by the departatent or delogated abecty; or

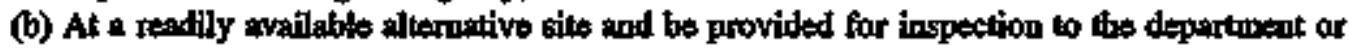
delegated agency upon requast."

\section{FACILITY REOUIREMENT SOURCE: WAC-173-360 Section 360}

\section{"Reporting of Suspected Relesses}

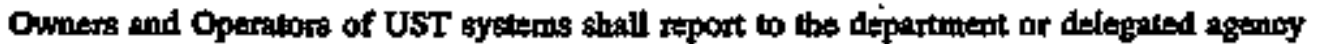
within twenty-four hours, or amother reasonnble time period specified by the department or delegated agency, and follow the procedures in WAC 173-360-370 when any of the following corditions apply:

(1) Owness and operrators or otbers discover relensed regulated bohitences at the UST site or in the surrounding aree fincluding but not limited to the presence of free product or its constifuents in soils, bessements, sewer acd utility thes, ground water, atodfor surface watert).

(2) Unusual opersting conditions are observed by owners or operatons (such as the erratic behnvior of product dispensing equipment, the sudden loss of a regulated substance from the UST system, ox an unexplained presence of water in the tank), unless system equipimant is foumd to be defective bot not leaking, and is immediately repaired or replaced; or

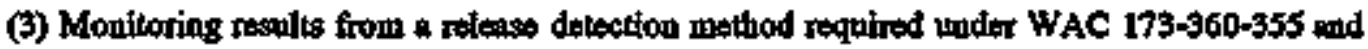
173-360-340 indicate that in releaso may have cocurred unless:

(b) The monitoring device is found to be defective, and is immediately repaired, recalibrated or repleced, and additional monitoring does not confirm the initial result; or

(c) In the case of inventory control, a second month of data does not confirm the initial result, except that owners and operators shall immediately investigate all larger-than-rormel or reoceurring variations in inventory control results, and report such variations if they are unacoonted for, without waiting to obtain a second month of datm *

\section{Bariological Eifluents}

This subelement specifies the standardis for maintemence and control of data and recorts of routine radiological effhent discharges apd/ar spills to the atmonsphete, surfinco waters, or ground water. 


\section{STANDARDS REQUIRFMENTS IDENTIFICATION DOCUMENT HIGH LEVEL WASTE STORAGE TANK FARMS \\ Environmental Protection \\ whC-FP-0750}

\section{FACIITIYY REQUIREMIFNT SOURCE: 40CFR61 Part 94}

"Compliance and Reporting

(a) Compliance with this stendand thall be determined by calculating the highest effectiva does equivilent to any member of the pablic at any off-site point where there is a residence, school, business or office. The owners or operatmrs of each facility shall submit an anmal report to both EPA hediquarters and the appropriate regional office by June 30 which includea the results of the monitoring as recorded in DOE's Efflueat Information System and the dnse calculationa required by 61.93(a) for the previous calendar year.

(b) Items 1 - 8 only

In addition to the requirements of paragraph (a) of this section, an monull report shall inchude the following information:

(1) The mame and location of the facility.

(2) A list of the rediowetive materitals used at the facility.

(3) A description of the handling and processing that the radioactive materials undergo at the tatility.

(4) A list of the stacks or vents or other points where radioactive miteriajs are released to the atmosphero.

(5) A deseription of the effiluent controls that are used on each stack, vent, or other release point and in estimate of the efficiency of each control device.

(G) Distonces from the points of release to the pearest residence, schoof, belsiness or office and the nearest prochs procing vegetables, mitk, and meat.

(7) The values used for all other user-eupplied input parameters for the computer models (e.t. meteonological data) and the source of these data.

(8) A brief description of all construction and modifications which were completed in the colendar year for which the report is prepared, trut for which the requirement to apply for approval to constract ar modify wos waived under 61.96 and associated documentation developed by DOB to support the waiver. EPA reserves the tight to reculiro that DOB send to EPA all the information that normally would be rexulied in an spplisetion to constroct or modify, following rectipt of the description and supporting docutubutation.

\section{FACILITY REQUIREMENT SOURCE: 40CFR61 Part 9s}

"Reconcikeeping Requirements

All faciltites must mairtain records documenting the source of input parameters incheding the resolts of all messurements upon which thay ane based, the calculations and/or analytical methods used to derive velues for input parameters, and the procecture used to determine effiective dose equivalest. This doctimentation should be sufficient to allow sn independent

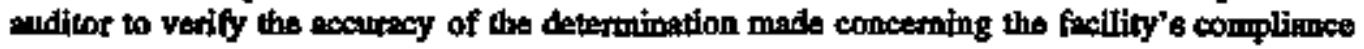
with the etendard. These records must be kept at the site of the facility for at leest flve yeant and, upon request, be made available for inspection by the Administrator, or his anthorized representative."

\section{FACILITY REQUIREMENT SOURCE: DOE/FH(0135 TS.5.6}

"Auditable reconds are kept which show the radioactive and hazardous material release quantities and qualities." 


\section{STANDARDS REQUIREMENTS IDENTIFICATION DOCUMENT BIGE LEVEL WASTE STORAGE TANK FARMS \\ Environmental Protection \\ WHC-EP-0750}

\section{FACIIIT REQUTRSMENT SOURCE: DOES460.1 Chapter II, Section 8.a}

"Effluent date for radionaclides should be Eummorized. The nuclides of concern and the totel mumber of curies in nirborne and liquid effluents released to the offrite environment ehould be included in the portion of the report dealing with air and water monitoring, nespectively. In

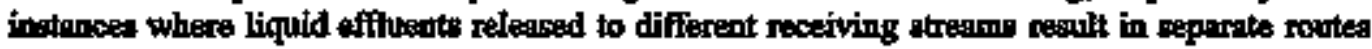
of potential exposhts, the radiosetivity discharged to each receiving stream should be Itentified. For purpases of reportiog radiological effined data, gross rationativity meaghuremerts are unacceptable, unless specified by applicalile federall, stath, or local requilations."

\section{FACILITY REQUIRGMENT SOURCE: DOR5400.1 Chapter I, Section 8.b}

Inciude a britiof desctiption of each of the media sampled *a part of the monitoring program or as pert of a epocial stody. The type and frequenoy of anupling and the methods of wallyris should bo presented. Individual data points are not required, but tebles, graphs, or text whoth clearly and accurtately preseat the overall monttoring results should bo provided. A map showing the locetion of monitoring stations and sampling points also sbould be included. AB a geoerol nula, deta ahould be presented for radionetivity in media for which thers ars applicable standards of other meaningful bases for interpreting the results. Interprotation should be made, where appropriate, of how the ervironmental leveds (resulting from site operations) compare to velevint porameters ach as beckground rudioactivity, and applicable effluent or environmental stondards."

\section{FACAITY REQUIREMENT SOURCG: DOES400.1 Chapter II, Section 8.c}

The Entironmental Report thould contain an assessment of the potential radistion exposure to the public which could havo resulted from site operations during the cleadur year. The assessment should be as eccurato and realistic as possible. The modeling and calculetion methodology used in the dose assessment should be included or referenced. A comparison of regulte with applicable etanderds and relevent parameters (e.g., ngtaral and manmado sources of exposure) also should be inchuded."

\section{FACILITY REQUIAEMIENT SOURCE; DOBS400.5 Chapter II, Section 8}

\section{-Records}

2. Content, Recorda developed shall include information and data neceseary to ideatify and characterize releases of mdioactive material to the environment, their fate in the erviromment, and their probabte impact on radiation doses to the patbitic. Basic information used to assess compliance with the requirements of this Order pursuant to paragraph 11.6, and the results of such assessments, shall be incorponated as part of the record.

b. Retention. Information and data developed pursunt to this Order stiall be retained consibteat with the requirements of DOE 1324.2A and other legally applicable requirements."

\section{FACILITY REQUIREMIENT SOURCE: USAEC-RG1.86 Section C.A}

Recotils 


\section{STANDARDS REQUIREMENTS IDENTIFICATION DOCUMENT HGH LEVEL WASTE STORAGE TANK FARMS Environimental Protection whepposso}

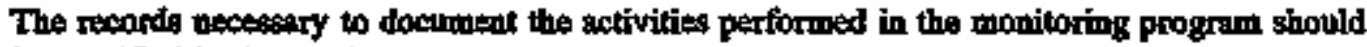
be epecified in the quallity assurance program.

Oas tey aspect of quatity control in maintaining the ability to track and control a sample in its proptes through the sequedce of monitoring processes. Records to accomplish fhis shomidd

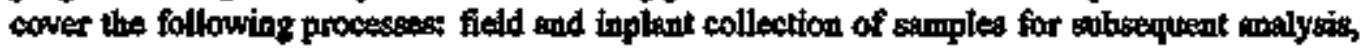
inoluding ennple description; somple recejpt and lahoratory identification coding; sample preparation and radiochemical processing (e.8. Lelboratory wotebooks); talioutivity

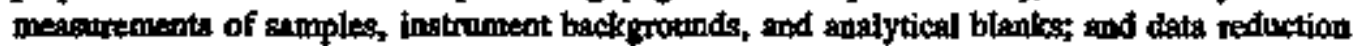
and verificetion.

Quality control records for laboratory continting aystemes ethmuld include the results of meseurements of rodionetive check sources, colibration sources, backgrounds, and blanks.

Records relating to overall laboratory performance stiould inchude the results of amelysig of quality control eafroles such os antlytical blamks, fuplicetes, interlaboratory cross-check samples and other quality control ansilyses; use of standards (radioactivity) to prepare wodking stendarda; prepparation and standardization of carrier solutions; and calfbration of analytical balances.

Additiont records that are needed should inchude the calibration of online radiation detection

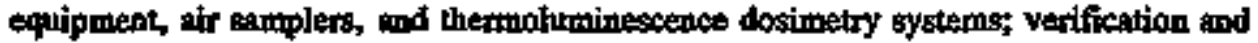
documentation of compater progrems; queiffications of persomel; and results of tanties

The miningum petiod of retention of the records should be specified."

FACILITY REQURRMANT SOURCE: WAC-2A6-247(940131) Section 080( 3)

The facility shall ans:aily submit to the department the information requirements adopted in subsection (2) of the section, as applicable, along with the following additional information, wo applicable:

(a) The results of enpission mesturements for those emission units stbject only to periodis confirmatory mesarrements;

(b) Wind rose or joint frequency table;

(c) Annual ntverage ambient temperature;

(d) Annual svenge emission unit temperature, if available; (e) Anmol total minfall;

(f) Anpunat average emisetion unit flow mbe and total volume of at rellesed during the celendar yesi.

If this additionsl information is arailable in another ammal report, the facility may insted provide a copy of that repart along with the information requirements in this suinsection. Ammul reports are due by June 30 for the previous calendar years's operations."

\section{FACILITY REQUREMENT SOURCE: WAC-246-247(940131) Section 080( 4)}

"Any report of epplication thet conteins propriekery or procurement-sensilive information shall bo submitted to the department with thase portions 80 desigalad. The department shall bold this information confidential, unless required to relense the irsormetion pursuant to lewe, repulutione, or court order."

FACILITY REQUIREMENT SOURCE: WAC-246-247(940131) Section 080( 5) 


\section{STANDARDS REQUIREMENTS DENTIFICATION DOCUMENT HIGH LEVEL WASTE STORAGE TANK RARMS \\ Environmental Protection \\ WHC-ER-OTSO}

"Tho tweility sheil notify the deportment within twrenty-four bours of any shuldown, or of any trentient abnommel condition lasting more than four hours or other thange in fecility cperations which, if allowed to persist, would result in emissions of radiosetive material in excese of appliceble standards or license requiresrents. If requested by the department, the fecility shall submit a written report wifhin ten daya including known canses, corrective actions takea, dad any proventive messurea talsen or planned to minimize or eliminate the chance of reclintuce."

\section{FACIIITY REQUIREMENT SOURCE: WAC-246-247(940131) Section 090( Q}

The freility ahall file a report of closure with the department whenever operations producing emissions of radioactive mattetial int permanently ceesed at any entrission chapter. The closure report ahall indiceto whethes, despile ceseation of operations, there is still a potential for redifoctive air enrissions and a need for an active or passive ventilution system with emission control and/or monitnring devices. If decommissioning is plinned and will constitute a modification, a NOC is requited, as applicsble, in accordance with WAC 246-247-060.

\section{FACILTY REQUIREMIENT SOURCE: WAC-246-247(940131) Section 080( 7)}

"The freility shall maintain a log for each emisefion unit that has received cetegorical approval under WAC 246-247-060(8). The log shall contain reconds of important operations parameters including the dete, location, and duration of the relesse, mearured or coliculated rodicapuctide concentration, the type of emissions (liquid, gaseous, solid) and the type of emission control and uroutitoring equipment *

\section{FACILITY REQUIREMRNT SOURCE: WAC-246-247(940131) Section 080( 8)}

"The ficility shell mainteitn reedily retrievible storage areas for all records and documents

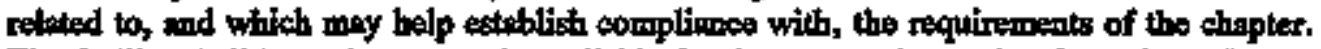
The fucitity shall trepp these recorits available for department inspection for at least five years."

\subsubsection{Spills and Discharges}

This gutelement specifies the requitements of WAC 173-303-145 for response to spills and discharges.

\section{FACIUITY REQUUREMENT SOURCE: WAC-173-303(931208) Section 149}

"Spills and discharges into the environment

145 (1) Purpose and apticability. This section sets forth the rexpinementa for any person responsible for \& epill or discharge, except when such release is otherwise permitted under ato or federal law. For the purposes of complying with this escion, a transporter who spills or discharges dengencus waste or hazardous aubstances during transportation will be considered the responsible person. This section shall apply when any dengerons wasto or hazardoum sabstance is intentionally or accidentally spilled or discharged (unless otherwike permitted), negandless of the quantity of dangerous waste or hazaridous substance.

145 (2) Notification. Any person who is responsible for a nonpermitted spill or discharge shell immectiately notify the individuals and amborities described for the following 


\section{STANDARDS REQUIREMENTS IDENTIFICATION DOCUMENT BIGE LEVEL WASTE STORAGE TANK FARMS \\ Eavironmental Protection \\ WHC-EPOTSO}

situotiong:

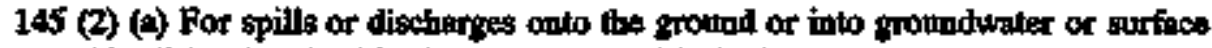
water, notify all locel authortites in novordance with the tocal emergency plan. If neceseary. check with the locel eprergency service cocordinator and the fire department to determima all notification responsibiltitieg under the local emergency plan. Also, notify the approprinte regional office of the department of ecology; and

145 (2) (b) For apilla or discharges which result in emiseions to the air, motify all looil anthorities in sccordance with the local emergency plan. If necessary, chect with the locel eunsorgency service coordingtor and the fire department to determine all notification reeponsibilities under the local emergency plen. Also, in western Washington notify the locel air pollution control tuthority, or in eastem Wastington notify the appropriate regional office of the department of ecology.

(145) (2) (d) In liteu of notification umder (c) of thits salbsection, for spills or discharges below tou gollons pccalriteg and cantsined in secondiry containment meeting the requirements of this chapter, a brite ceopint mikst immediately be entered into the operating record, for a TSD facility, of into the tispection log or separate spill log, for a genentor. This account nmet inclust: The time and date of the spill; the location and caluse of the spill; the type and quentity of mosterial spilled; and a britf description of any tesponse antions taken or plemed.

145 (3) Mitigation and control. The person responsible for a nonpermitted spill or diecharge shall take appropriate immediate action to protect human .health and tho environment (a.g., diking to provent coatamination of state weters, shutting of open valves).

145 (3) (a) In addition, the department may require the person responsitte for $h$ spill or discharge to:

145 (3) (1) Cleen up all released dengerous wristes or barardous substances, or to taka guch ections as may be required or spproved by federal, state, or local officials acting within the scope of theit official responsthilittes. This may include complets or partial removil of veleased dangerous wastes or hazarilous substanoes as may be justified by tho nature of the veleased dangerous wastes of hazandous substances, the buman and environmental circumatanes of the incident, and protection required by the Water Pollution Control Aat, chapter $90.48 \mathrm{RCW}$;

I4S (3) (ii) Designals and treat, stort or dispose of all soils, waters, or other materials contaminated by the spill or discharge in mecordance with this shepter 173-303 WAC. The department may require testing in order to determine the amount of extent of contsuinated materiale, and the appropriate desiguation, trestment, storage, or disposal for any materials revoulting from clean-up; and

145 (3) (iii) If the property on which the spill or discharge occursed is not owned or controtted by the perscon responsible for the incident, restore the area impacted by the spill of discharges, and repleaish resourtes (e.g., fisi, plants) in a manner acceptable to the deportweat.

145 (3) (b) Where immodiats rewoval or temporary storage of spilled or discharged demgerous wastes or haxardous aubstances is necessary to protect human beat th or the 


\section{STANDARDS REQULREMENTS IDENTIFICATION DOCUMENT FIGH LEVEL WASTE STORAGE TANK FARMS \\ Environmental Protection \\ Whe-BP-9750}

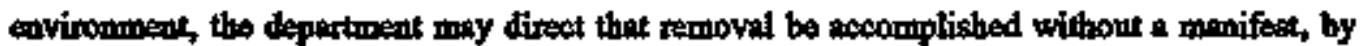
transportere who do not hrve EPA/state identification numbers.

145 (4) Nothing in WAC 173-303-145 shall eliminate any obligations to comply with neporting requirements which may exist in a permit of under other stats of federal nogulations."

\section{Damaernus Waste}

This subelement specifies the requirements for factlity recorrikefping for dangerous wasto TSD unitg.

\section{FACILITY REQUIREMENT SOURCE: WAC-173-303 Section 810(11)}

-810 (11) Monitonimg and monitoring records.

810 (Il) (o) All permite shall specify:

810 (11) (a) (1) Requirements concerning the proper use, maintenance, and installation, when appropitiate, of montaring equipmedt or methods; and

sto (I1) (a) (ii) Required monitoring inchuding type, intervals, and frequecy sufticient to yield dete which we representative of the monitored activity including, when approptiate, continuous monitoring.

810 (11) (b) Samples and measurements taken for the parpose of momitoring thall be representative of the mopitored activity.

810 (11) (c) The permittee shall netain records of all monitoring information, including all

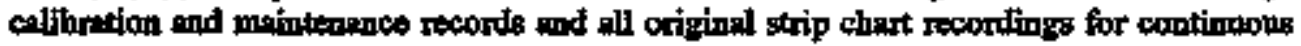
monitoring instrumentation, copies of all trports required by this permit, and records of all date used to completer the application for this permit, for a period of at least three yeass from the date of the sample, messurement, report, or application. This period may be extended by request of the department at any time.

810 (11) (d) Records of monitoring information shall includes

810 (11) (d) (i) The date, exact place, and time of sampling or measurements;

810 (11) (d) (i) The individual(s) who performed the sampling or measurements;

810 (11) (d) (iii) The date(s) analyses wero performed;

810 (11) (d) (iv) The individual(s) who performed the analyses;

810 (11) (d) (v) The analytical techuiques of methods used; and

810 (11) (d) (vi) The results of such analyses.

810 (11) (e) The permittes shall tratiotain all recorts of ground water quality and ground water aurface elevations for the entive life of the factlity, and for the post-clogure period as wall." 


\section{STANDARDS REQUIREMENTS IDENTIFICATION DOCUMENT BIGF LEVEL WASTE STORAGE TANK FARMS \\ Environmental Protection \\ WHC-ERMTSO}

FACHITY REQUIREMENT SOURCE: WAC-173-303(931208) Section 380(1)

Focility recondkepping

Openting record. The owner or opentor of a facility shall beep a written operating record at his fweitity. The following information shall be recorded, sa it becomes avallable, and meintained in the openting record matit closure of the facility:

(a) A description of and the quantity of esch dangerous waste received or managed an-aito, and the method(g) and date(s) of its treatment, storage, or disposal at the facility as required by subsection (2) of this section, recordkeeping instructions;

(b) The location of ecth daugerous wasto within the facility and the quartity at wen locotion.

For disposal fecilitiea, the location and quantity of each dangerous waste must be recorded on a map or diagram of each cell or disposal area. For all facilities, this information must inchude cross-referenced to specifie manifest document numbers, if the wasto was accompanied by a manifest;

(c) Records and resultu of waste anelyses required by WAC 173-303-300, General waste analysig;

(d) Summory reports and details of all incidents that require implementing the contingency plan, as specified in WAC 173-303-360 (2)(k); (e) Records and results of irspections as required by WAC 173-303-320 (2)(d), General inspection (except sweh information need be kept only for five years);

(f) Monitoring, lesting, of andytical dath, and corrective action where required by 40 CFR Part 265 Subporti $F$ through R for interim status factilites, and by WAC 173-303-630 through 173-303-680 for fint and furilities

(g) All closume and post-clooure cost estimetes requited for the facility; and

(h) For off-site facilities, copies of notices to genterators informing them that the facility has all appropriato permits, as required by WAC 173-303-290, Required notices."

\section{FACILITY RDQUIREMENT SOURCE: WAC-173-303(931208) Section 380(2)}

"Fectility recondlkeeping

Recontikeping instructions. This paragraph provides instructions for resording the portions of the operating record which we related to describing the types, quentities, and manggement of dangerous wastes it tib fucility. This informition stiplt be kept in the operating record, as follows:

(a) Each daugerolss waste received or mangged shall be described by its common name and by ito dengerous wasto momber(s) from WAC 173-303-080 through 173-303-104. Where a dangarous wasto contains mone than ons process waste or waste constifunent the waste description must inchude all applicable dangerous waste numbers. If the dangeroug waste number is not listed then the wasto description shall include the process which generated the waste; (b) Ths wasto deseription shall include the waste's physical form (i.e., liquid, solid, sludge, or gas);"

\section{FACILTY REQUIREMENT SOURCE: WAC-173-303(931208) Section 380(3)}

"Facility recontlkeeping

Aveilatiolity, retention and disposition of records.

(a) All faellity records, incluting plans, required by this chapter must be furmished opon request, and mado availabile at all reasonablo tínes for inspection, by any officer, employee, or representative of the depertment who is destigated by the divector.

(b) The nteotion period for all factily reconds required under this cheppter is extended antomatically during the course of any unresolved enforcement action regarding the facility or af requested hy the director. (c) A copy of records of weste disposal locetions and quantitieg 


\section{Environmental Protection \\ WHC-ER-0750}

under thin section mest be solbuttted to the United States EPA regionsl administrator, the department, and the locell lend uss and plannimg anthority upon closure of the facility."

\section{FACIITY REQUIREMIINT SOURCE: WAC-173-303(931208) Setion 390(1)}

The owner or operatior of a fapitity is aesponsitite for preparing end submilting the reports deseribed in this section.

(1) Unmenifested waste raports, If a fecility weopts any dengerous wwste from an off-site source without an accompanying menifest of shipping paper, and if the waste is not excluded fom the menifest requirements of dhis chapter 173-303 WAC, ben the owner or operitor must

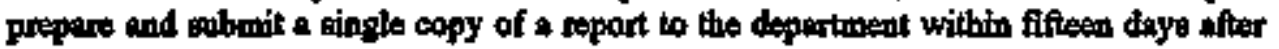
reseiving the wosto. The report form and instnutions is the Unomonifested Dangerous Waste Report - Form 6 (which may be obsained from the departmens) mnst be used for this report. The report must include at least the following information:

(a) The EPA/state identification namber, name, and address of the facility; (b) The dats the facility received the waste;

(c) The EPA/atate identification nomber, name, and address of the genetator end the transporter, if available;

(d) A desoription and the quantity of each unmanifested deagerous waste the favility received;

(e) The method of managemost for each dangerous waste;

(C) The certificetion kipped by ths owner or operaber of the facility or his authorized tepresentitives oud

(a) A brit explenation of why the waste was unmonifeested, if known.

\section{FACILITY REQUIREMIENT SOURCE: WAC-173-303(931208) Section 390(2)}

"(2) Anmial roports. The owner or operator of a facility that holds an activs EPA/state identification number shal prepare and stbmit a single copy of an anmul report to the department by Manch 1 of ench year. The report form and instructions in the TSD Facitity Annuel Dangerous Waste Report - Form 5 (which may be obtained from tho depertment) arust bo used for this report. In adslition, tan fwility whish ships dangerous waste off-site must comply with the onpual reporting requitrements of WAC 173-303-220. The annul report mast cover facility metivitiea during the provious colectar year sond must includs, but ig not limited to the following toformation:

(a) The EPA/state identification number, noms, wnd address of the fiecility; (b) The calendar yeur covered by the reports

(c) For off-eite fucilities, the EPA/state ideutification number of eth dengeroug waste penerator from which the fiecility received a dangerous waste during the year. For infortad shipments, the report nomst give the name aud address of the fortign generator,

(d) A description and the quantity of each dabgerous waste the fincitity received during tho year. For off-site frecilities, this information must be tisted by EPA/state identification number

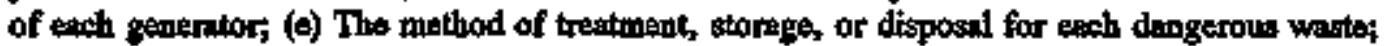

(f) The most recent clasure cost estimate under WAC 173-303-620)(3) (or 40 CFR 265.142 for interim stabus facilities), fod for disposal freilities, the most recent post-closure cost estimate tonder WAC 173-309-620(5) (or 40 CFR 265.144 for interim status factilities); and

(c) The cerdificetion sigaed in accordance with the requiriments of WAC 173-303-s10(12)."

FACILITY REQUIREMENT SOURCE; WAC-173-303(931208) Section 390(3) 


\section{STANDARDS REQUIREMTNTS IDENTIFICATION DOCUMENT FIGF LEVEL WASTE STORAGE TANK FARMS

\author{
Euvironmental Protection \\ whIC-ER-OT50
}

-Additional reporte. The chiner or cpenutor shall aleo report to the deppartment releases of dengerous wastes, fires, and explosions *s specified in WAC 173-303-360 (2)(k) ind interim etabus groundunter monitoring dath, as specified in 40 CFR 265.94 (a)(2) and (b)(2).

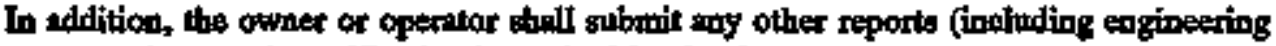
reports, plans, and specifications) required by the departentert."

\section{PACILTY REQUIREMONT SOURCE: WAC-173-303(931208) Section 390(4)}

"(4) Recordkeping. The owned/operator of \& factity shall keep \& copy of all unmanifested waste reports, annual teports, and any other reports salbmilted to the depurtment according to the requitrements of this section for a period of thres yerre from the diste the report was submittod."

\section{TANK REGULATIONS}

This alement specifies the requiraments for operation of underground dangerous waste storage tonks arrd undergrovend diesel fuel storage tanks as regulated under the Washington Administrative Corle. The seope of these requirements excludeg WAC 173-303-640 (2) which opecifies detailed destign and installation requirements for new tenk systemg.

\section{Tank Systems}

This gubelemed sqecifites the tank inteprity requirements provided in WAC 173-303-640.

\section{FACILITY RTQUIREMIENT SOURCE: WAC-173-303(931208) Section 640( 2)(a)}

For exh existing tank system, the owner or operator must determine that the tank aystem is not lesking or is unfit for use. Except as provided in (b) of this subsection, the owner or

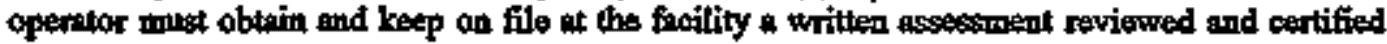
by an independent, qualified registered profassional engineer, in accortinese with WAC 173-303-810 (13)(a), that attests to the tank system's integrity by Jannary 12, 1988, for underground tenles that do not meet the requirements of subsection (4) of this cannot be eatered for inspection, of by January 12, 1990, for all other tank syatems."

\section{FACILITY REQUIREMENT SOURCE: WAC-173-303(931208) Section 640( 2)(b)}

"Tani systems that atoro or treat materials that become dangerous wastes gubsequent to Janusy 12, 1989, must conduct this assessment within twelve months after the date that tho waste becoumes a dangerous waste."

\section{FACLITY REQUIREMENT SOURCE: WAC-173-303(931208) Section 640( 2)(c)}

-This assessment must determine that the tank system is adequately designed und has sufficient structureal streagth and contuptibility with the waster(s) to be stoned or treated, to ensure that it will not collapse, rupture, or fiil. At a mintmum, this assessment must consider the following: 


\section{STANDARDS REQUIREMENTS IDENTIFICATION DOCUMENT HIGH LEVEL WASTE STORAGE TANK FARMS \\ Envirommental Protection \\ WHC-EP-0750}

(i) Design stendad(8), if arailible, weording to which the pents bystem was constructed:

(ii) Dengerous characterietics of the waste(s) that have been and will be hendked;

(iii) Existing corrosion protection messures;

(iv) Documented age of the tark system, if available (otherwise, m estimgte of the age); and

(v) Resxilts of a leak test, internal inspection, or other taqk system integrity examination such thet:

(A) For nconenterable underground tanks, the assessment wust include a leak leat that in capable of taling into account the effects of temperature variations, tank end deflection, vapor pockets, and high weter whlo effects; and

(B) For other than nontenterible underground tanks and for ancillary equijpment, this

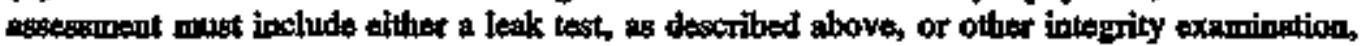
that is certified by an independent, qualified, registered professional engirser, in wcordamco

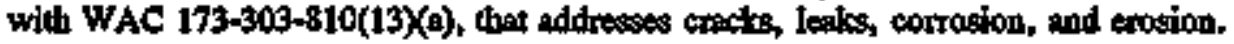

Note: Tht practices described in the Americat Petroleum Institute (APD) Publication, Guide for Inspection of Refinery Equipmant, Chapter XIII, "Atmospheric and Low-Pressure Stornge Tauks", 4tb odition 1981, mxy be used, where appiticable, ss guidelines in conducting other then a leak test."

FACILITY REQUIREMENT SOURCE; WAC-173-303(931208) Section 640(2)(0)

"If, is a result of the assessment conducted in meondance with (a) of this subsection, a thrk system it found to be leaking or unfit for use, the cwner or operator must comply with the requiremeats of stibsection (7) of tris section."

\section{FACILITY REQJTREMENT SOURCE; WAC-173-303(931208) Section 640(2)(e)}

The owper or opentor mitst develop a schedule for condacting integrity assessments ow the bife of the tmk to easure that the tank retains its struetural integrity and will not collepes, niptart, or thit. The schedelle wust bo bosed on the results of past integrity sssessments, age of the tank system, materials of constriction, chanteteristics of the whste, and any other relovent fartors."

\section{FACILITY REQUREMANT SOURCE: WAC-173-303(931208) Section 640( 4)(a)}

In order to prevent the rolease of dangerous waste or dengerous constituents to the environment, secondary containment that meets the requirements of this stbsection minst be provided (except es provided in (f) and (g) of this subsection):

(i) For ofl now tank systemes or components, prior to their being put into service;

(ii) For all existing tante systems used to store or treat Dangerous Waste Nos. FO2O, FO2t, F022, F023, F026, and F027, within two years after January 12, 1989;

(iii) For those existing tank systems of lmown and documented age, within two years after January 12, 1989, or when the tank system has reached fifteen years of ago, whichever comea 


\section{STANDARDS REQURRMMENTS IDENTIFICATION DOCUMENT HIGH LEVEL WASTE STORAGE TANK FARMS \\ Environmental Protection \\ WHC.Ep.07so}

loter;

(iv) For those existing tank systems for which the age cannot be documented, within eight years of Jarnary 12, 1989; but if the age of the facility is greater than seven years, secondary contuinment must be provided by the time the facility reaches fifteen yeary of age, or wilhin two yesrs of Jammry 12, 1989, whichever comes later; and

(v) For tonl aystemg that store or treat materisls that become dangerous wastes subsequent to Jambary 12, 1989, within the time intervajs required in (a)(i) through (a)(iv) of this subsection, except that the date that a matarial becomes a dengerons waste must be used in place of Jennary 12, 1989."

\section{FACUITY REQUIREMENT SOURCE; WAC-173-303(931208) Section 640( 4)(b)}

"Secondiny conteinment systems must be:

(i) Desipned, installed, and operated to prevent any migration of wastes or accumpulated theid out of the system to the soil, frotind water, or sinftece water at any time during the use of the tank system; and

(ii) Capable of detecting and collecting releases and accumulated liquids tmitil the collected material is removed."

\section{FACILTY REQUIREMENT SOURCE: WAC-173-303(931208) Section 640( 4)(c)}

To meet the requirements of (b) of this subsection, secondary containmeat systems must be at a minimum:

(i) Constructed of of lined with materials that are compotible with the waste(s) to be pleced in the tank eystem and must have suficient strength and thickness to prevent failure owing to pressure gradients (including static hend and axtemal hydrological forces), physical contact with the waste to which it is exposed, cilmatic conditions, and the stress of daily cperations (inchuding stresses from nearby vehicular traffic);

(ii) Placed on 2 foundation of bass capable of providing support to the secondary containment system, resistance to pressure gradients above and below the system, and copable of preverting failuye due in settlement, compression, of uplitit;

(iit) Provided with a leak-detection system that is designed and operated so thet it will detect the failure of either the primary or secondary containment structure or the presence of any release of dangerous waste or accumulated litguid in the secondary coatainment system within twenty-four bours, or at the earliest practicable time if the owner or operator can demonstrate to the department that existing detection technologies or sitte conditions will not allow detection of a release within twenty-four hours; and

(tv) Sloped of otherwise designed or operated to drain and renowe liquids resolting from leaks, spills, or precipitation. Spitted or leaked waste and accurrulated precipimation mist bo removed from the secondary containment system with twenty-four hours, or in as timely a

manner as is possible to prevent barm to human bealth and the environment, if the owper or operator can demonstrate to the department that removil of the released waste or eccumulated precipitation cennot be accomplished with twenty-four bours." 


\section{FACILITY REQUUREMENT SOURCE: WAC-173-303(931208) Section 640(4)(d)}

"Secondary containmeat for tanks must include ons of more of the following dovices:

(i) A liner (external to the tank);

(ii) A vauls

(iii) A double-walled tan's or

(iv) An equivalent device ss epproved by the department."

\section{FACIIFY REQUIRBMENT SOURCE: WAC-173-303031208) Section 640( 4)(e)}

TI adilition to the requirementu of (b), (c), and (d) of this sulisection, secondery contaimmete syotenn most astisfy the following requiremeats:

(i) Extermal linar systema must be:

(A) Designed or operated to contain one hundred petcent of the capacity of the largest tank within its boundary;

(B) Desigped or cpetaled to prevent nu-oq or infitration of prectpritation into the secondery conteinment system unlese the collection system has sufficient excess capacity to contain run-og or fofiltration. Such edditional capacity must be sufficient to contain precipitation from a twenty-five-year, twenty-forr-hour rainfall event.

(C) Fros of cracks or gaps; and

(D) Designed and installed to surround the tank completely and to cover all surmounding terth Tikely to come into contact with the wasto if the wasto is released from the tank(s) (i.e., capplibs of preventing lateral as well as vertical migration of the waste).

(ii) Voult oystems mast bes

(A) Desigoed or operated to contain ono hundred percent of the capacity of the largest tank within its boundary;

(B) Designed or operated to prevent run-on or infiltration of presipitation into the secondary containment system unless the collection system has sufficient excess epentity to contain

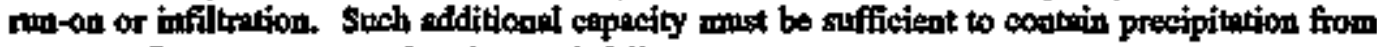
on twenty-five-yest, twenty-four-hour minfoll events

(C) Constracted with abemical-resistent water stops in placs at all joints (if any);

(D) Provided with an impermethls interior coating or lining that is compatible with the stored Whistes and that will prevent migration of waste into the concretes;

(E) Provided with a means to protect against the formation of end ienition of vapors within the vault, if the waste being stored of treated:

(I) Meets the definition of ignitable waste under WAC 173-303-090(5); or

(II) Meetr the definition of reactive wasto under WAC 173-303-090(7), and may form an iquitable or explosivg vapor. 


\section{STANDARDS REQUIREMENTS IDENTIFICATION DOCUMENT HIGA LEVEL WASTE STORAGE TANK FARMS \\ Environmental Protection wic-Br-0350}

(F) Provided with an exterior mointure barrier or be otherwise designed or operated to prevent migretion of moisture into the valult if the vanit is aubject to hydranlis pressoro.

(iii) Doublo-walled tanlse must be:

(A) Designod as an integral structure (1,t, an inner tank completely enveloped within an outer athelli) 20 that any colease from the inner tank is contained by the outser shell;

(B) Protected, if constructed of metal, from both carrosion of the primary tank taterior and of the exteridel sarface of the other shell; ad

(C) Provided with a built-in continuous lesk detection system capablo of detecting a releaso within tweaty-four hours, or at the earlitest practicalbe time, if the owner or operator can deamonstrate to the department, and the department conchudes, that the existing detection texbnology or site complitions would not allow detection of a release within twenty-four hours.

Note: The provisions cutlined in the Steel Tant Instinute's (STI) "Standard for Doral Wall Underproumd Steel Starape Tanks" moy be used as guidelines for aspects of the desigo of uoderground ateel double-walled tanks."

\section{FACLITY REQUIREMENT SOURCE: WAC-173-303(931208) Section 640( 4)(f)}

"Ancillary equipment must be provided with secondiny containmedt (0.g., trench, jicketing, doublewwalled piping) that meets the requirements of (b) and (c) of this subsection except for: (0) Aboveground piping (exclusive of flanges, joints, valves, and other comections) that are visually inspecied for lealss on a datly basis; (ii) Welded flanges, welded joints, and welded connections, that are visually inspected for leaks on a daity besis;

(ii) Seafless or magnetic coupling pumps and sealless valves, that are vigually inspected for leaks on a daily basis; and

(iv) Preseurized aboveground piping systegns with automatio ghut-off devices (o.g., excess flow check valves, flow metexing shutdown devices, loss of prescure actuated shut-off devices) that aro virually inspected for leaks on a daily busis."

\section{FACILITY REQUIREMANT SOURCE; WAC-173-303(931208) Section 640( 4)(g)}

"The owner or operator may ohtain a vartence from the recuirements of this mubsection if the department finds, as a result of a demonstration by the ownes or operater that alternative design and operating practices, together with location characteristics, will prevent the migration of any dangeron wrsto or dangerous constituents into the groumd water, or gurfase water at least an effoctively as secondary containment during the active life of the tank system or that in the event of a release that does mignite to groumd water or surface water, no substantial present or potential hersurd will be posed to buman health or the environment. New

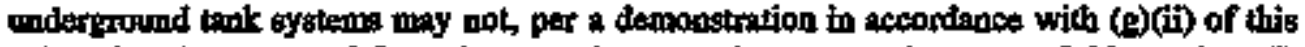
sabsection, be axempted from the secendery contrinment requirements of this section. (i) In deciding whether 10 geant a variance based on a demonstration of equivalent protection of ground water and gurface water, tha department will consider:

(A) The nabute and quamily of the wastes;

(B) The proposed alteriate design and operation;

(C) The hydrogeologic setting of the facility, including the thickness of soils present between the tank system and ground water; and

(D) All other factors that would influence the quality and mobility of the dengerous constituents and the potsotial for them to migrate to ground water or surface wrter. 


\section{STANDARDS REQUIREMENTS IDENTIFICATION DOCUMENT HIGH LEVEL WASTE STORAGE TANK FARMS \\ Gnvirommental Protection \\ WHC.RP-0750}

(i) In deciding whether to grant a yariance bused on a demonstration of no substantial present

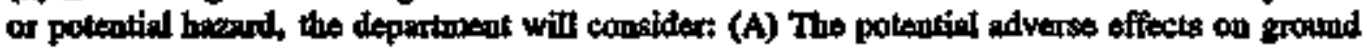
water, surfece water, and land quality cuking into acootult:

(I) The physical and chemical characteristics of the waste in the tanle system, inchuding ite potential tor migration;

(ir) The hydrogeological chancteristics of the facility and surroumding land;

(III) The potential for hestth rislss culused by humen exposurt to wasto coustiments;

(IV) The potentivl for damige to wilditis, crops, vegestion, and physicol thuchurea coused by expostris to wasto comstiousents; and

(V) The persistence and permaneoce of the potential sdverse effects. (B) The potential adverse

effects of a release on groond-water quality, tol'ing into eccount:

(D) The quentity and quality of ground water ind the direction of ground-water flow;

(II) The proximity and withdrawal rates of gronnd-water users; (III) The comrent and future

uses of ground water in the are; and (IV) The existing quality of ground water, including other exurces of contamination and their cumulativo impect on the ground-water quality. (C)

The potential adverse effects of a reless on surface water quality, taking into accoumt:

(I) The quantity and quality of ground water and the direction of ground-water flow;

(II) The patterns of ritinfall in the region;

(III) The proximity of the tants bystem to surfics waters;

(IV) The curnent and future oses of surface waters in the ares and any water quality stondards established for lhose surface waters; and

(V) The exiating quality of surface water, including other sonrces of contsmination and the comolative impet on surface-water quality. (D) The potential adverse effects of 4 release so tho land gurroming the tank system, taking into account:

(D) The patterns of rsinfall in the region; and

(II) Tho current and future uses of the surrounding land.

(iii) The ouner or operator of a tunk system, for which a vartince from secondary containment had been granted in weordinge with the requirements of $(g)(t)$ of this gibsection, w which a

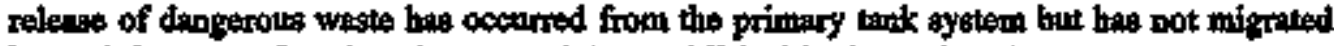
beyond the zoos of engineering control (as established in the vartauce), must:

(A) Cormply with the requiroments of sulusetion (T) of this section, except aubsection (7)(d) of this sootion; ind

(B) Decoutamingte or remove contuminated sail to the extent necessery to: (I) Enshle the tank syatem for which the variance was granted to resume cperation with the copability for the detection of roleases at least equivalent to the capability it had prior to the release; and (II) Provent the migration of dengerous waste or dangerous constituents to groumd water or surface water.

(C) If conterminated soll canos bo rewoved ar deconthminated in wetordance with (G)(iit)(B) of this sulsection, comply with the reculitements of subsection (8) of this section.

(iv) The owner or operator of a tank system, for whteh a varianco from had been grented in scoondance with the requirements of $(g)(t)$ of this sabsection, at which a release of dangerous waste has ocearred from tho primary tank system and hes migrated beyond the zone of engineering control (as estabtished in the variance), must:

(A) Comply with the requirements of subsection ( $(\mathrm{A})$, (b), (C), and (d) of this section; and

(B) Provent the migration of dengerous waste or dengerouts constitoents to ground water or

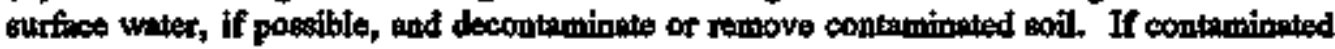
boil chomot be decontamineted or menoved of if ground watar hos been contaninated, the owner or operator must comply with the requirements of subeotion (8)(b) of this section; and (C) If repairing, replecing, of reinstalling the tank bystem, provide secondary containment in accondance with the requiremeats of (a) through (I) of this subsection or neapply for a veriances from secondary containment and meet the requirements for now tank systems in aubeection (3) of this section if the tank syatem is replaced. The owner of opesetor must comply with these 


\section{STANDARDS REQUIREMFNTS WENTIIICATION DOCUMENT HIGH LEVEL WASTE STORAGE TANK FARMS \\ Environmental Protection \\ WHC-ER-OBSO}

requirements even if contaminated soil can be decontaminated or removed and ground water or auface water has not beed contaminated."

This aubelement specifies the tank operating reguifements provided in WAC 173-303-640.

FACTLIY REQUIREMIENT SOURCE; WAC-173-303(931208) Section 640(5)

"Generd operuing requirements.

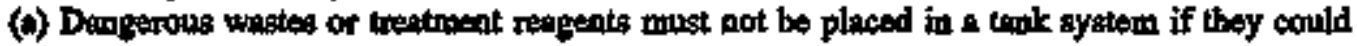

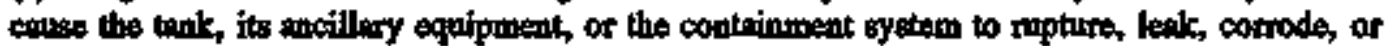
otherwise firil. (b) The owner or operator must ust appropriate controls ind practices to prevent spills and owerflows from tank or containment systems. These include at a mimimum: (i) Spitl prevention controls (e.g., check valves, dry cisconnect couplings); (ii) Overfill prevention controls (e.g., level sensing devices, high leved alarms, automotic feed cotofif, or bypase to a standiby tans); and (ii) Maintenance of sufficient freeboard in umeovered tanks to prevest overtopping by wave or wind action or by precipitation.

(c) The owner of cperator unust compiy with the requirements of subsection (7) of this section if a leak of spill oceurs in the tarik system. (d) All tank systems holding dangerous wasto shall

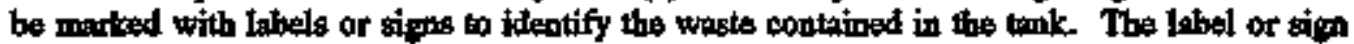
thill be legitile it a distence of at least fifty feet, and atrall bear a legend which identifies the waste in a manner which adequately warms exployees, emergency response persomel, and the public of the major risk(s) esseciated with the wasto being stored or treated in the tank system(s). (Noto-If there already is a systam in use that performs this fixnction in accordances with local, state or fedeml repulations, then stish system will be edequate) (e) All tant gyttems bolding EHW whith is equtely or chronicelly toxic by inbalation must be designed to prevent eecoupe of vapors, fumes, of cther amisstons into the air."

\section{Leng.. kerponse}

This subeldment speoiffes the tank lesk response requirements provided in WAC 173-303-640.

\section{FACILTTY REQUREMENT SOURCE: WAC-173-303(931208) Section 640( 7$)$}

"Response to leaks or spills and disposition of leaking or unfit-for-use tank systems.

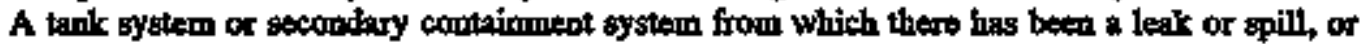
which is tufit for use, wust be renoved from service farmediately, and the otroer or operator must antisfy the following tequirements!

(a) Cessation of use; prevent fow or addition of wastes. The owner or operator must immediakely stop the flow of dugerous weste into the tank system or secondary conteinment aystem and inspect the system to determine the carase of the release.

(b) Remroval of waste from terk system or secondary containment system. (i) If the relasse whs from the the system, the owner/optrator must, within twenty-four hours after detection of the lesk or, if the owues/operattor demonstrates that it is not possible, at the eartiest practicatile tims, rewowo as much of the waste as is necessary to prevent further release of dangerous woste to the euvironemet and to allow inspection and repair of the tent eyetem to bo perforwed. 


\section{STANDARDS REQUIREMENTS IDENTHICATION DOCUMENT BIGH LEVEL WASTE STORAGE TANK FARMS \\ Euvironmental Protection \\ Who-Et-0750}

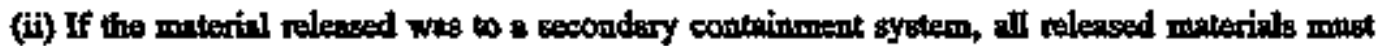
be ramoved within twenty-four hours or in as timely a mimmer as is possible to prevent harm to buenen health and the environment, (c) Containment of visible releases to the environment. Tho ownetoperator mist inmediately conduct a visual inspection of the releaso and, besed upon that inspection:

(D) Prevent further migration of the leak or spill to spill or artace water, and

(ii) Remowe, and property dispose of, any visible contemination of the soil or surfuce water.

(d) Notifications, reports.

(i) Any relesses to the envirominth except is provided in (d)(it) of this aubection, whust be reported to the depardment within tweoly-four houra of its detection. Any release above the "reportable quartity" must also be reported to the National Respouse Couter purstrent to 40 CFR Part 302. (ii) A leat or spill of dengercess waste is exemuted fiow the requirsmente of (d) of this gubection if it is:

(A) Lese then or equal to a quantity of one pound, of the "Roportable Quantity" (RO) eatroblished in 40 CFR Paxt 302, whichever is Iess; and (B) Inmediately contained and clecned-up.

(ii) Within thitty days of detection of a release to the enviramment, a report containing the following information must be submilted to the department:

(A) Likely route of migration of the release;

(B) Characteristics of the aunouading 60 il (soil composition, geology, hydrogealogy, climatb);

(C) Resnlts of my monitoring or sampling conducted in connection with tho release (if svailable). If sampling or monitoring data relating to the relesse nre aot available within thirty

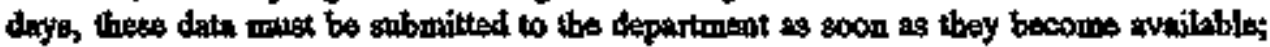

(D) Proximity to downgradient dirinking water, sufface water, end popplatad aress; and

(E) Description of tesponse actions taken of planned.

(e) Provision of becoudary containument, repait, or closurta.

(i) Untess the ownerioperator aatisfies the requinements of (o)(ii) through (iv) of this suhesetion, the tank syaten must be closed in accordance with subsection (8) of this section.

(i) If the cause of the release was a spill that has not damaged the integrity of the system, the cavner/operator may return the system to sorvice as soon as the released wasto ia removed ind repeiva, if necessary, aro made. (iti) If the canso of the release was a leak from the primary tank ayatem into the secondary containment system, the system must be repaired prior to returning the tank system to eervice.

(iv) If the source of the release was a lesk to the eavironment from a component of a tmk system without secondisy contininment, the owner/operitor milst provids the somponent of the

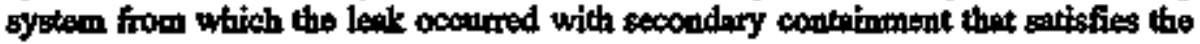
requirementa of aubsection (4) of this section before it can be retumed to service, unless the source of the leak it an eboveground portion of a tank system that can be inspected visuetly. If the source in an aboveground component that can be inspected visually, the component must be repaired and may be returuted to servite without secordary conkainment as long wa the recpuirements of (f) of this subsection ire satisfied. If a component is replaced to comply with the requirements of this subitem, that component mest satisfy the requirements for new tomt systems or components in sulbsections (3) end (4) of tids section. Additionally, if a leat has oceurred in any portion of a tonk syetem component thest is not readtly acescsible for visund

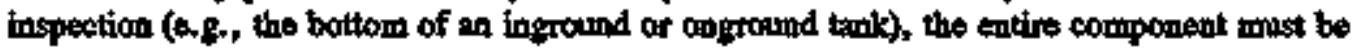
provided with eccondery containment in ecordance with subsection (4) of this section prior to beting returned to use.

(f) Certification of mejor repeirs. If the owner/optrator has repaired a tonk system in

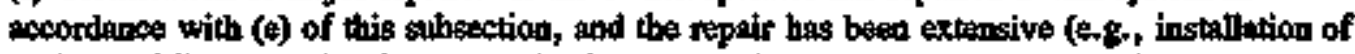
con internal liner, reptir of a ruptured primary containment or secondary containment vessel), the tank syetem must not be returned to service unless the ownerioperator has obtained a certification by on independent, qualitied, registered, professional enginer in scoondames with 


\section{STANDARDS REQUIREMENTS IDENTHICATION DOCUMENT HIGH LEVEL WASTE STORAGE TANK FARMS \\ Environmental Protection \\ Mic-EP-0950}

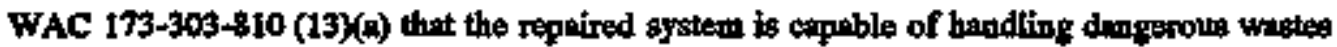
without relesse for the toteaded lifo of the system. This certificetion mmst be submilted to the department within sevea deys efter reburning the tank system to use.

Note: Seo WAC 173-303-320 for the requirements necessery to remedy a failore. Also, 40 CFR Part 302 may requtire the ownter or operator to notify the Natiosel Responge Center of certion meleasea."

Iputitable, Reactixe_and Incompatihle Wastes

This subelement specifies the requirements for ignitable, reactive and incompatible wasteg provided in WAC 173-303-640.

\section{FACIITY REQUIREMENT SOURCE: WAC-173-303(931208) Section 640( 9)}

-Special requirements for ipnitable or reactive wastes.

(a) Igritable or resctive waste mast not be placed in tank systems toless: (i) The waste is treated, rendered, of mixed before ar immediately after platementin the tank system so that the resulfing waste, mixhure, of dissalution of material do longer meets the definition of igriteble of reactive waste under WAC 173-903-090, and 173-303-395 (1)(b) bs complied with; or

(ii) The waste is stored of treated in such a way that it is protected from any material or conditions which may cause the waste to ignite or react; or (iii) The tank system is used solely for exporgencites,

(b) The owner or operator of a facility which treats or stores tenitable of resctive waste in tanks must locate the tanks in a mammer equivalent to the National Fire Protection Association's buffer zone requirements for tanks, contained in Tables 2-1 through 2-6 of the NFPA-30 Flammable and Combastible Liquits Code - 1981, or ne required by stato and locel fire codes when such cotes are mors stringent. The owner or operator shall also conply with the requirements of WAC 173-305-395 (1)(d).*

\section{FACILITY REQUIRGMENT SOURCE: WAC-173-303(931208) Section 640(10)}

Special requitements for incompatible wastes.

(a) Incompatible wastea, or incompatible wastes and materials, must not be plased in the samo tonk Bystem, unles WAC 173-303-395 (1)(t) is complied with.

(b) Dengerous wasto must not be ploced in a tank system that hes not been deccontaminated and that previously held an incompatible wasto of material, unless WAC 173-303-395 (1)(b) is complied with. [Statutory Authority: Chapters 70.105 and 70.105D RCW."

\section{Onderground Storage Tanks}

This subelement specifies the requirements applinable to the underground diesel storage tanks provided in WAC 173-360.

FACILITY REQUUREMENT SOURCE: WAC-173-360 Section 305(1)(b),(2)(b)

Performance Stendards for Cafodic Protection

If the trits and/or piping (1) routinely contains regulated substances, (2) is in contact with the ground, and (3) is constructed of steel (0.g., not of fiberglassoteinforced plastic or of a steel-fiberolase-reinforeed-plastic composite), then it must be cathodically protected in the 


\section{STANDARDS REQUIREMENTS IDENTIFICATION DOCUMIENT FIGH LEVEL WASTE STORAGE TANK FARMS \\ Envirommental Protection \\ WHC-EPQO750}

followints mennitr:

(i) Tho tank and/or piping is copatot with \& auftable dielectric material;

(ii) The tank is equipped with a factory-instilled or fiedd-installed cathodic protection system

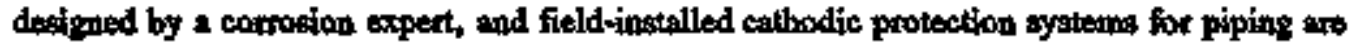
designed by a corrosion expert;

(iii) Cathodic provection gystems are designed and installed to include provisiong for torting to allow a detsminination of esrreot operating status as requiyed in WAC 173-360-320(2) and to freilitate testing by Ecology or delegated ageooy in eccondance with WAC 173-360-325 (5) and (6); and

(iv) Cathodic prokection Bystems ane operated and maintained in accordance with WAC 173-360-320, or eccorting to guidelines established by Ecology or delegated agancy, or the codes and stunderds listed in WAC 173-360-305 (1)(b)"

\section{FACILTY REQUIREMMENT SOURCE; WAC-173-360 Section 305(3)(a),(b)}

\section{Spill and Overflow Pravertion Equipment}

Uthless the UST system in filled by transfers of less than 25 gallons it onetime, of Ecology-approved alterpative equipment is used, then owners and operatoss will use the following spill and overfill prevention equipment to prevent spilling and overfilling essociated with transfer of regulated substances to the UST zystem:

(i) Spill provention equiprent list will prevent the release of regulated substances to the environment when the transfer hose is detached from the fill pipe (for example, a spill cutchment basin); and

(i) Overfill prevertion equipment that will:

(A) Automatically shut off flow into the tank when the tank is no mort than 95 \% full;

(B) Alent the thasfer operator when the tork is no mare than $90 \%$ full by restrietiog the flow into the tank of triggering a high-level alarm; of

(C) Restrict flow thity minutes prior to overibling, alent the operator with a hish-level alarm one minute before overfilling, or mulsomatically slawt off flow into the tank 60 that note of the fittinge located to top of the tank are exposed to regulated substances des to overfilling.

Note: Overflow prevention equipment that with automatically shut off or restritt fiow into the tents should not be used where a pressurized fuel transfer system may be employed sinco an overflow may aceur when the flow is suddenly shut off or restricted."

\section{FACMITY REQUIREMENT SOURCE: WAC-173-360 Section 310(1)}

"Upgrading Requirements For Existing UST Systems

(1) Altermotives allowed.Not later than December 22, 19998, all existing UST systems shall comply with one of the following reyairements: 


\section{STANDARDS REQUIREMENTS IDENTHFICATION DOCUMENT BIGH LWVLL WASTE STORAGE TANK FARMS \\ Environmental Protection \\ WHC-ER-0750}

(a) New UST system performance standerds under WAC 173-360-305;

(b) The upgrading requitements in subsections (2) through (4) of this section; or

(c) Closure requirements under WAC 173-360-380 through 173-360-398, including applicable requirements for corrective action under WAC 173-360-399.

\section{FACILITY REQUIREMENI SOURCE: WAC-173-360 Section 315}

"(1) Spill aud Overflow Control Requirements Ownerg aud operators shall enstre that teleases dwe to spilling of overflowing do not ocewr. The owner and operator sholl ensure thet the volume available in the mik is greater than the volume of regulated entastances to be trensferred to the tank before tho transfer is made and that the transfer"

\section{FACILTY REQUIREMIENT SOURCE: WAC-173-360 Section 320}

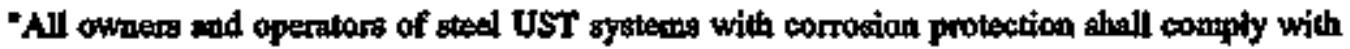
the following requirements to engure that reteases dwe to corrosion are prevented for as long a the UST oystem is used to atore rogulated substantes:

(1) All corrotion protection systems shall bo operated and maintained to concinuously provide cotrosion protection to the metal components of that portion of the tank and piping that routinely contain regulated substances and are in contact with the ground.

(2) All UST systems equipped with cathodis protection systems shall be inspected for proper opention by 4 licensed bupervisor of ealbodio protection installation and testing in accordanco with bo following reyulinements;

(n) Frequency. All celhodio protection cystems sball be tested when they are installed, and

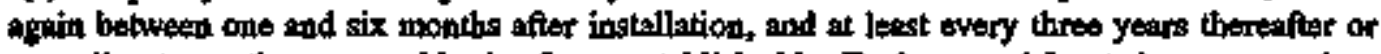
wecording to another tearonable timeframe established by Feology or delegated agency; atd (b) Inspection eriteria. The criteria that are used to determine that cathodic protection is adequats as required by this section shall bo in sccordance with a code of practice developed by a mationally necognized association. NoteNational Association of Corrosion Enginoers Standard RP-02-85, "Control of Exteroal Corrostion on Metallic Burted, Purtilly Buried, or Submerged Liquitd Stange Systems," may be used to comply with thits subsection.

(3) UST systems with impressed current cathodic protection systems shall also be inspected overy 60 days to ensurs the equipment is running properly.

(4) For UST systems using cathodic protection, records of the operation of the cathodic protection shell be meintrined to demonstrate compliance with the performance standaris in this section. These records shall provide the following: (a) The results of the last three inspections required in subsection (3) of this section; and (b) The results of testing from the lest two inspections required in subsection (2) of this section.

(5) Tank pervices providers who perform any of the tank services deseribed in this section shall certify that such services comply with the requirements of this section by submitting the appropriate chexklist(s) to the department in accordance with WAC $<D<11849>>173-360-$ $630</ D>(12)^{\prime}$

EACIITY REQUIREMENT SOURCE: WAC-173-360 Section 345(6)(c) 


\section{STANDARDS REQURRMENTS IENTIFICATION DOCUMENT HIGH LEVIL WASTE STORAGE TANK FARMS \\ Environmental Protection \\ WHC-EP-0750}

"Monthly tin' gauging.

Only tentos that store fiml solely for woe by emergency power gentatione with a nominat ceppecity of two thoussad pallons of les may use moutbly tank gauging as a mathod of rolease

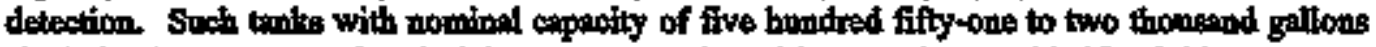

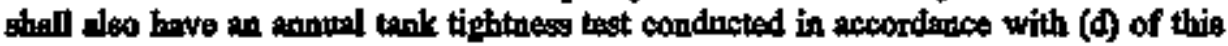

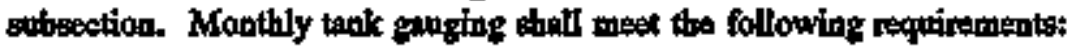

(i) Irventory valume mesurements for repuleted sulstemes inpuls, withdrawalk, and the amount still rematning in the tank are recorded whenever inputs or withdrawals aocur,

(ii) Tank liquid level measurements reconciled with inventory volume mensurements aro talken monthly at the beginning and ending of a period of at kast tweaty-ane days, except when extreme enowfall or other bavel cbstructions occurring in remots locations and proventing accosa are epecifieally documented by the owner and operntor;

(iii) Level messurements are besed on an average of two consecultive readings at bath the beginning ard ending of the period (hat is, four mensurements shall be taken, two consecutive meagurementh at the beoinning and two consecultive measurements at the oud of the period);

(iv) The equipment used is capable of measuring the level of regulated substance in the tank over the full radge of the tank's height to the neerest one-eighth of an inch or a corcesponding amourat of gallons;

(v) Tho messurement of any water level in the bottom of the tank is made to the nearest ono-ighth of an inch at least once 2 month;

(vi) If the variation between beginning and ending mensurements exceeds the monthly standard in the following table, a leak may be occurring and the requirements of WAC 173-360-360 through 173-360-375 shall bo followed:

Nominal Tank Capacity Monthly Standard (svenge of four tests)

$\begin{array}{ll}550 \text { gallom or less } & 5 \text { gallons } \\ 551-1,000 \text { gallons } & 7 \text { gallons } \\ 1,001-2,000 \text { gallong } & 13 \text { gallons" }\end{array}$

FACHITY RTQUIREMENT SOURCE: WAC-173-360 Section 345(0)(d)

Tank tightnes testing.

Tank Tightoess testing (or snother test of equivalent performince) sball be capable of detecting at lengt $\mathbf{0 . 1}$ gallon per hour leak nate from any portion of the tank that routinely containg a regulated sulbstance whito socounting for the effects of thermal expinsion or contraction of the regulated substance, vapor pockets, tank deformation, evaporation of condeasation, and the location of the water bible."

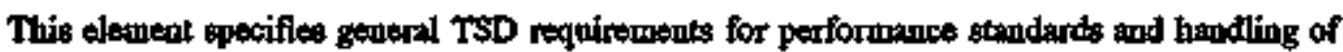
ignitable, neactive, or inconquatible wastes applicuble to Tink Forms. 
STANDARDS REQUIREMENTS IDENTIFICATION DOCUMENT

BIGH LEVEL WASTE STORAGE TANK FARMS

Environmental Protection

WHC-EP-0T50

\section{FACILITY REQUIREMIRNT SOURCE: WAC-173-303(931208) Section 395(2)}

"(2) Coumliance with other eovironmental protection lawe and regralations If receiving. storing, hodating, treating, procescing, or disposing of dangerous wastes, the ownet/operator ahell design, maintoin snd operate his dangeross waste facility in compliance with all upplicahle federal, stote and local laws and regulations (0.8-, control of atormuater of senitory wates discharge, control of volatile air emiesions, etc.)."

\section{Pextormance Standerds}

This subelement epecifies the requirements of WAC 173-303-283 for gentral performincs

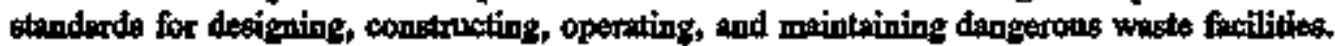

\section{FACILITY REQUIREMENT SOURCE: WAC-173-303(93L208) Section 283(1)}

"(1) Purpose. This section provides general gerformance standards for desipning, constructing, operating, and mainteining daugerous wast factities,"

\section{FACLITY REQUIREMENT SOURCE: WAC-173-303(931208) Section 283(2)}

(2) Applicability. This section opplies to all dingerous waste facilities permitted under WAC 173-303-800 flrough 173-303-840. Tbese generil performonoe stenderds sholl be used to detsonine whether thore strimgent facility standaris should be applied than those spelled out in WAC 173-303-280, 173-303-290 through 173-303-400 and 173-303-600 through 173-303-670."

\section{FACILITY REQUIREMIRNT SOURCE: WAC-173-303(93L208) Section 283(3)}

"Performance Standerte. Unlese muthorized by state, locsl, or federal laws, or milese olberwise authorized in this tegulation, the owver/opertor shall desigu, construct, operate, or

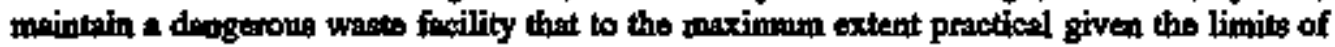
technelogy preventar

(a) Degradetion of pround water quality;

(b) Degradition of air quality by open burniog of other activities;

(c) Degradetion of surfice water qualityi

(d) Destruction or impairment of flora and fauna outside the active partion of the facility;

(o) Ercessive noise;

(f) Conditions that constitute a negative aesthetic impact for the public using rights of wrye, or public tonds, or for landowners of adjecent properties;

(g) Unstale hillsides or soils as in result of treoches, imponodments, axcavations, etc;

(h) The nse of processes that do not treal, detoxify, recycle, reclaim, and recover waster material to the extent economically fensible; ind 
STANDARDS REQUIREMENTS IDENTIFICATION DOCUMENT

HIGH LEVEL WASTE STORAGE TANK FARMS

Environmental Protection

Who-arabso

(i) Endongerment of the health of employes, or the public aear the ficility."

Iquitable and.Reactive Wastes

This autrelement apecifies the requirements of WAC 173-303-395(1) for igniminle and reactive wasteg.

\section{FACILTTY REQUIREMINT SOURCE; WAC-173-303(931208) Section 395(1)}

"(1) Precantiong for ignitoble, reactive, or incompatible wastes.

(a) The owner or operator must take precentions to prevent eccidental ignition or reaction of ignitbble or resctive wasts. This waste must be separated and protected from sources of ignition or reaction inchuding, but not limited to, open flames, smoking, cutting and wejding, hot aurfess, frictionai heat, sparks (static, eleetrical, or mechanical), spontaneors igaibion (a.g., from heat-producing chemical reactions), and radimt heat. While ignitablo or reactive wasto is being hendled, the owner or operator must confine amoking and open flsms to specially designrted locations. "No smoking" signs must be conspicususly placed wherever thene is a havard from ignitable or resctive waste.

(b) Where epecifically required by other sections of this chapter 173-303 WAC, the treatment, storage, or disposal of ignitable or reactive waste, and the mixture or commingling of incompatible wastes, or incompatible wastes and miterials, must be condicted so that it does not:

(i) Generate extreine heat or pressure, fire or explosion, or violent reaction;

(ii) Produce umcontrolled toxic mists, fumes, dusts, or gases in sufficient quantities to threaten buman bealth or the environment;

(iii) Produce uncontrolled flammable fumes or gases in sufficient quantitie to pose a risk of firo or explosions;

(iv) Demage foe seructeral integrity of the facility or device containing the wasts; of

(v) Through other like meang, threaten human bealth or the enviromment.

(c) When required to comply with (a) snd (b) of this subsection, the owner or operator must

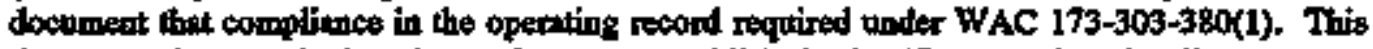
docaumentation moy be based on reforences to published scientific ar enginesting literature, dota from trial testa, waste analyses, or the rosults of the treatapent of similar wastes by similar treatment processes and under similar operating conditions.

(d) At lesst yeariy, the owner or oporator sbell inspect those areas of his factility where igribible or renctive wastes are stored. This inspection stall be performed in the presence of a profestional person who is familiar with the Uniform Fire Codes or in the presence of the locel, state, or federal fire marahal. The owner ot operator thall enter the followidg infornation in his inspection log or operating record as a result of this inspectiont

(i) The date and time of the inspection;

(ii) The name of the professional inspector or firs marshal; 


\section{STANDARDS REQUIREMENTS IDENTIFICATYON DOCUMENT FIGH LEVEL WASTE STORAGE TANK FARMS \\ Environmental Protection \\ WhA.EP-OBSO}

(iii) A notation of the observations medie; and

(iv) Any nemedial wetious which were taken 25 a result of the inspection."

18.9

$\underline{18.9 .1}$

18.9 .2

$\underline{18.9 .3}$

18.94

18.9 .5

18.10

\section{KEY INTEREACES}

This element describes key functional interfeces. The key interfaces for Envitonmental Protaction are Training and Qualification, Quality Assurance, Waste Management, Emergency Manngersent, and Occupational Safoty and Health.

\section{Thining and Outallection}

The troining bud qualfifietion aspects of environmentel protection programs are not included in the EP funotional ares and are planed in the Treining and Quralification functional ares.

\section{Ouglify Assurance}

The Quslity Aseurance (QA) functional sres and its requirements apply to all items, activities, and proceses manged by Tank Farms. The QA functionol anea is integrated into the EP programs through managameat, perfornance, and assessment.

\section{Waste Manazement}

The EP finctional area provides for the development and implementation of programs for protection of the environment. This program provides oversight to the waste management functional area which focuses more narrowly on the identification, characterization, and management of dangerons wastes.

\section{Emecoency Maugrement}

The Emergency Managemed functional area defines the emergency planning, preparthess, nod responsa netivities which are required by the various permits and plans included in the EP functioual and The Bmergency Management functionst area focuses on the preparation for and respouse to off-normal avedts.

\section{Occumational_safetre and Health}

The Occuppational Sufety and Health funotionel area focuses on the programs and procedurea for protection of workers and the peablic. These prostams interface routinely with the EP programa to provide protestion to workers respondiag to incidents of routinely operating processes which heve the potential to threaten the envitonment.

\section{REFARENCE SECTION}

The following refereace doctuments wers used to prepare the Environmental Protection fuactional area doclamest.

1) Weshington Administrative Code 173-160, Minimum Standards for Construction and 
Meintepance of Wellis."

2) Washington Administrative Cods 173-200, "Water Quality Standards for Groumdwater of tho State of Weshington."

3) Weshington Adwinistrative Code (WAC) 173-303, Demgenous Waste Regulationg."

4) Washington Administrative Code 173-307, "Ptans"

5) Washington Administrative Code 173-360, "Underground Starage Tank Regulations,"

6) Washington Administrative Code 173-400, "General Regulations for Air Pollution Sources."

7) Washington Administrative Code 173-460, "Controls for New Sources of Toxic Air Pollutants."

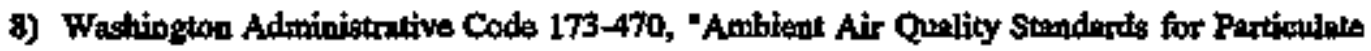
Matter."

9) Wathingten Administrutive Code (WAC) 173-480, "Aubient Air Quality Stoudarit and Emission Limits for Radionulides."

10) Washingtron Administrative Code 197-11, Washington Stute Environmental Policy Act (SEPA) Rulea,"

11) Weshington Administrativa Code 246-247, "Radioactive Wasto."

12) Wsahington Administrative Cods 246-272, "On-Site Sewnge System"

13) Washington Administrative Code 246-290, "Public Water Suppliea،"

14) 40 CFR Part 61, National Emissions Standards for Famprdous Air Poilutants."

15) 40 CFR Part 191, "Environmental Protection Standards for Management and Disposal of Spent Nuclear Fuel, High-Level, end Transuranio Radioective Wastes, "

16) 40 CFR 265, "EPA Interim Status Stundards for Owners and Operntors of Hezandono Wasto Facilities."

17) 40 CFR Part 264, "EPA Regulations for Owners and Operators of Permitted Hazandous Waste Fucilities."

18) 40 CFR Part 355, "Emergency Planning and Notification."

19) 40 CFR Part 370, "Harardous Chemical Reporting; Comnmaity Right to Know.

20) 40 CFR 372, "EPA Toxic Chemical Release Reporting Reguletions."

21) 40 CFR 1501, "National Environmental Policy Act and Ageacy Planning."

22) DOE Orier 5000.3B, "Occurrence Reporting and Processing of Operations Information." 


\section{STANDARDS REQUIREMENTS WENTIFICATION DOCUMENT \\ HIGH LEVEL WASTE STORAGE TANK FARMS \\ Environmental Protection \\ WHC-BP-075}

23) DOE Otder \$400.1, Geocral Ervirommontal Protsction."

24) DOE Order 5400.5, "Radiation Protection of the Public and the Envitonment."

25) DOE Order 5484.1, "Environmental Protection, Safety, and Health Protection Information Reporting Requirements."

26) DOE Onder 5820.2A, "Radioactive Waste Management."

27) DOEJEH-0173T, Rudiological Eftluent Monitoring and Environmental Surveillanca."

28) DOE/EA-0135, "Paformance Objectives and Criterim for Technical Safety Appraisals at Depportareat of Energy Facilities and situs."

29) NRC 4.15, Einvironmental Surveillance and Mopitoring Quality Assurance."

The following references were revioused thut not incloded in preparation of the Environmental Protection S/RD.

1) Federal Ageacy Hazandous Waste Compliance Docket July 18, 1991, Raymond E. Ludwiszswaki.

2) EPA Pollution Prevention Strategy, 56FR 7849, Fubruary 26, 1991.

3) Effluent Monitoriog Reporting Requirements, 10CFR Purt 70.59.

4) Whole Effluent Toxicity Testing and Limits, WAC-173-205.

5) Superfund Implementation, Executive Order 12580.

6) Implementation of Section 311 of the Federral Water Pollution Control Act, Executive Order 12777.

7) Pedend Compliande with Pollution Control Standards, Executivo Ordef 12088.

8) Starm Water Waste Manggemeat For Industrial Activities Summary Guidance. 